\title{
Uma Abordagem Baseada em Ontologias e Conectores para a Integração Semântica de Ferramentas de Análise de Expressão Gênica
}

Flávia Akemi Miyazaki

\author{
DISSERTAÇÃO APRESENTADA \\ AO \\ PROGRAMA INTERUNIDADES EM BIOINFORMÁTICA \\ DA \\ UNIVERSIDADE DE SÃO PAULO \\ PARA \\ OBTENÇÃO DO GRAU DE MESTRE \\ EM \\ CIÊNCIAS
}

\begin{abstract}
Área de concentração: Bioinformática
Orientador: Dr. Cléver Ricardo Guareis de Farias (FFCLRP/USP)

Co-orientador: Dr. Ricardo Zorzetto Nicoliello Vêncio (FFCLRP/USP)
\end{abstract}

Durante a elaboração deste trabalho a autora recebeu apoio financeiro da CAPES

- RIBEIRÃO PRETO - SP -

2011 


\title{
Uma Abordagem Baseada em Ontologias e Conectores para a Integração Semântica de Ferramentas de Análise de Expressão Gênica
}

\author{
Este exemplar corresponde à redação \\ final da dissertação devidamente corrigida \\ e defendida por Flávia Akemi Miyazaki \\ e aprovada pela Comissão Julgadora.
}

Comissão Julgadora:

- Prof. Cléver Ricardo Guareis Farias (Orientador) - FFCLRP-USP

- Profa. Agma Juci Machado Traina - ICMC-USP

- Profa. Angela Kaysel Cruz - FMRP-USP 



\section{AGRADECIMENTOS}

Agradeço aos meus pais e irmãos que me apoiaram e me deram forças em todos os momentos da minha vida. Agradeço à minha família, meus tios, primos e avós que estiveram sempre presentes na minha vida me dando forças. Obrigada família por serem os pilares que me deram base para formar a pessoa que sou hoje.

Meus sinceros agradecimentos ao meu orientador, professor Cléver Ricardo Guareis Farias, e ao meu co-orientador, Ricardo Zorzetto Nicoliello Vêncio, que sempre me apoiaram e ampararam durante todo o desenvolvimento deste trabalho de mestrado e me mostraram o caminho certo para trilhar e para obter um resultado de sucesso.

Muito obrigada à secretária Patrícia Martorelli por todo carinho, dedicação e disponibilidade.

Agradeço aos meus amigos, que estiveram comigo nos momentos bons e ruins da minha vida, cada um com sua contribuição especial em diferentes momentos.

Agradeço a CAPES pelo apoio financeiro.

Finalmente, agradeço a todos pela paciência, pela companhia e principalmente por terem acreditado em mim, muito obrigada. 


\section{RESUMO}

As pesquisas em biologia molecular têm produzido uma grande quantidade de dados, os quais embutem informações sobre diferentes fenômenos biológicos. Neste sentido, a bioinformática se destaca como uma área de pesquisa multidisciplinar que visa, principalmente, o desenvolvimento de ferramentas (sistemas) computacionais para auxiliar na descoberta de conhecimento a partir de dados biológicos. Dentro da bioinformática, a área de genômica funcional procura estudar as funções gênicas através da medição simultânea e em larga escala dos níveis de expressão gênica de um genoma.

Diferentes ferramentas são utilizadas no processo de análise de expressão gênica, cada qual provê suporte a uma atividade de análise específica. Embora alguns ambientes de descoberta de conhecimento ofereçam suporte integrado a este processo de análise e exploração de dados, a maior parte das ferramentas de análise é desenvolvida independentemente de outras ferramentas e ambientes de descoberta de conhecimento. Este cenário representa um desafio para biologistas que precisam combinar e integrar diferentes ferramentas, muitas vezes de forma ad hoc, custosa e sujeita a erros.

Modelos conceituais, tais como ontologias, têm contribuído para o sucesso do desenvolvimento de sistemas computacionais em diferentes domínios de aplicação. O desenvolvimento de tais modelos tem por objetivo representar corretamente, em alto nível de abstração, conceitos e situações pertinentes a um dado domínio de interesse. Esta representação abstrata facilita não apenas o entendimento de um dado domínio, mas também serve como base para o processo de desenvolvimento do sistema como um todo.

O objetivo deste trabalho é investigar o desenvolvimento e o uso de modelos conceituais em geral e ontologias em particular, na integração de ferramentas na área de análise de expressão gênica. De forma específica, este trabalho tem por objetivo propor uma abordagem para a integração semântica de ferramentas de análise de expressão gênica a partir do uso de conectores e de uma ontologia de domínio. Essa abordagem foi aplicada no desenvolvimento de estudos de caso envolvendo a criação de diferentes ambientes integrados para a análise de expressão gênica e mostrou-se eficaz. 


\begin{abstract}
Molecular biology researches are increasingly producing large amounts of data regarding underlying biological phenomena. Bioinformatics is a multidisciplinary research field whose main objective is the development of theories and information systems to help the process of knowledge discovery from biological data. Functional genomics is a field of study bioinformatics concerned with the study of gene function through parallel and large scale expression measurements of a genome.

A variety of software tools are usually combined and used in a knowledge discovery process, each providing support for a specific data analysis task. Although some tools are already provided as part of an integrated knowledge discovery environment, most of them are developed independently of other software tools and knowledge discovery environments. This scenario poses a problem and a challenge for biologists that need to combine and integrate different tools in an ad hoc, time consuming and error prone process.

Conceptual models, such as ontologies, have contributed to the successful development of information systems in different application domains. The development of such models aims at creating a clear and precise description of the elements of a given domain at a high abstraction level. This abstract and high level description not only promotes a shared understanding of the domain, but also serves as basis for the development process of supporting applications in the domain.

This work aims at investigating the development and use of conceptual models in general and ontologies in particular to support the integration of gene expression data analysis systems. Specifically, this work proposes an approach for the semantic integration of gene expression analysis tools using connectors and a domain ontology. This approach was applied in the development of a number of case studies aiming at creating integrated environments for gene expression analysis and proved its effectiveness.
\end{abstract}




\section{SUMÁRIO}

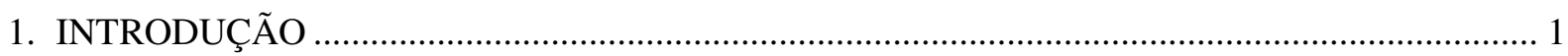

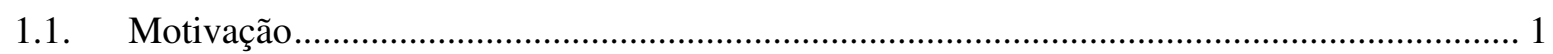

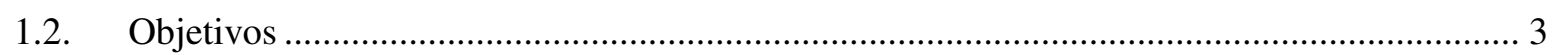

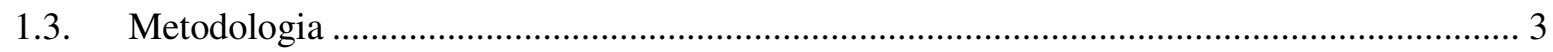

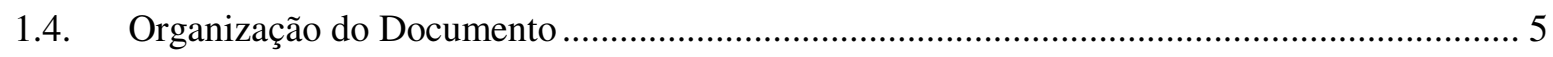

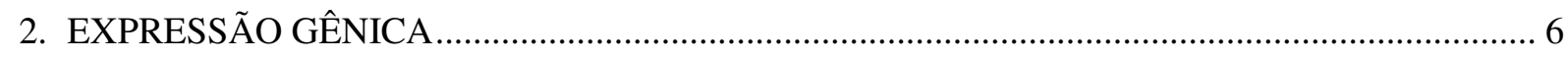

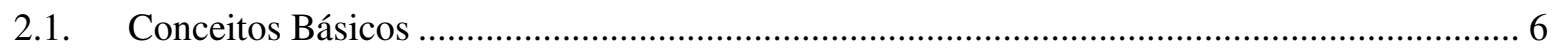

2.2. Abordagens Para Obtenção de Dados de Expressão Gênica....................................................... 7

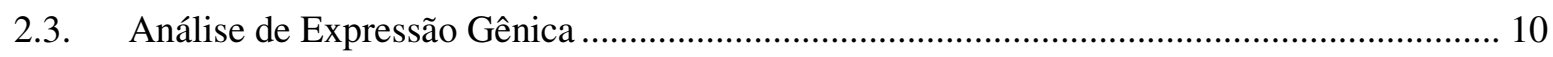

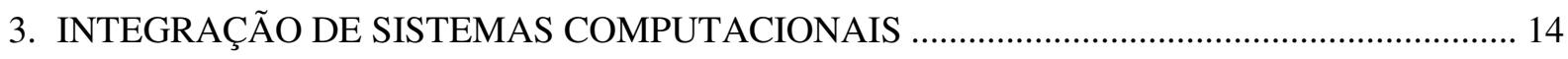

3.1. Desafios da Integração de Sistemas Computacionais ........................................................ 14

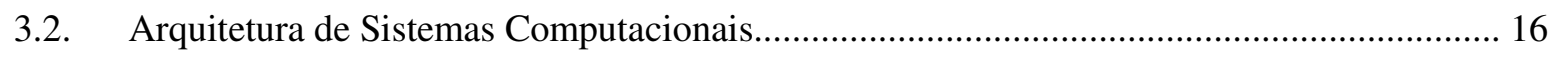

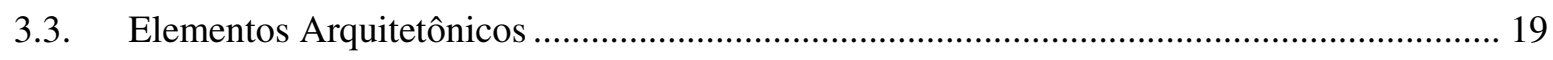

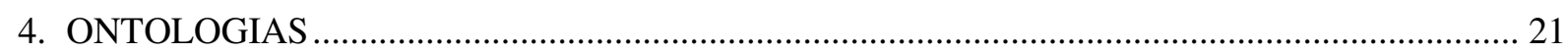

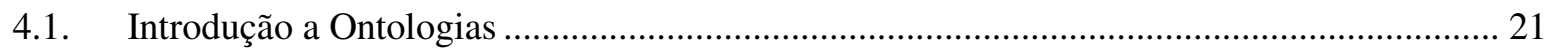

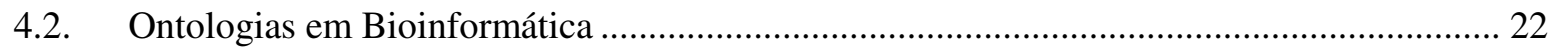

4.3. Integração Baseada em Ontologias .............................................................................. 25

4.4. Metodologias de Desenvolvimento de Ontologias............................................................... 27

4.5. Linguagens Para Representação de Ontologias....................................................................... 29

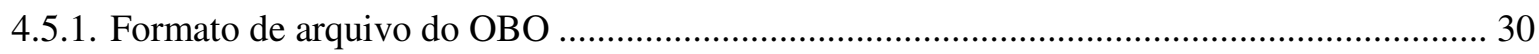

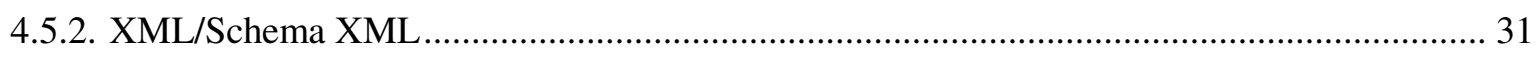

4.5.3. Resource Description Framework (RDF)/ RDF Schema................................................... 32

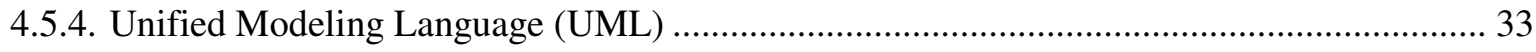

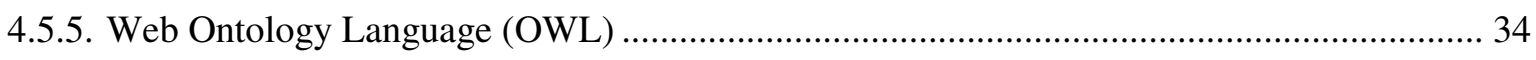

5. ABORDAGEM DE INTEGRAÇÃO SEMÂNTICA BASEADA EM CONECTORES ................. 36 


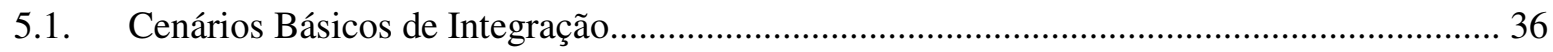

5.2. Diretrizes Para Desenvolvimento de Conector .................................................................... 37

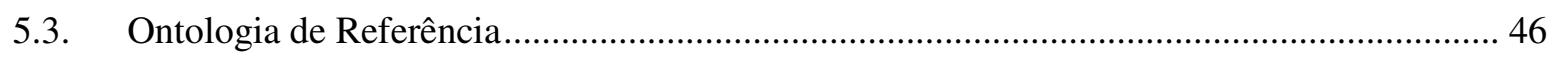

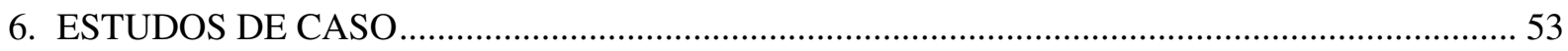

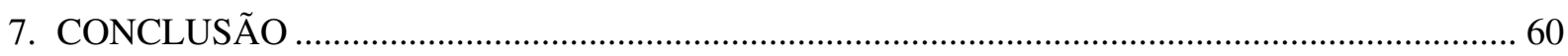

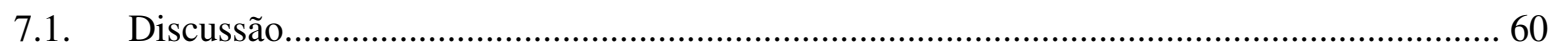

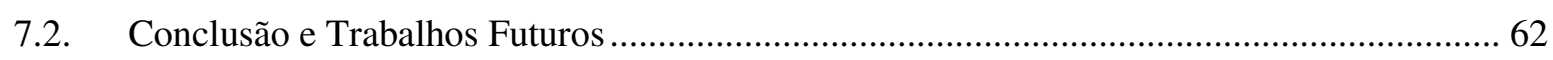

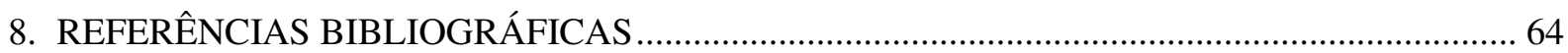

APÊNDICE A - Desenvolvimento do conector entre as ferramentas DMV e RGui - Primeiro estudo

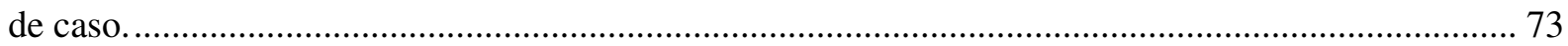

APÊNDICE B - Desenvolvimento do conector entre as ferramentas RGui e TMeV - Primeiro estudo

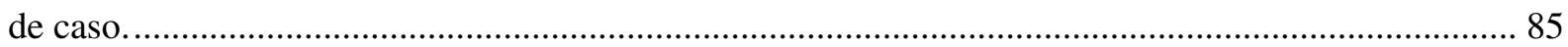

APÊNDICE C - Desenvolvimento do conector responsável pela integração de um banco de dados

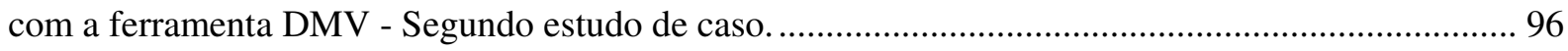

APÊNDICE D - Desenvolvimento do conector responsável pela integração das ferramentas DMV e

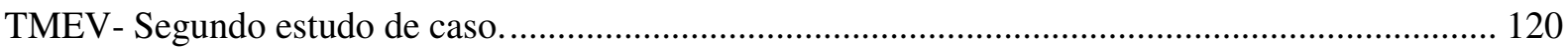

APÊNDICE E - Desenvolvimento do conector entre banco de dados e a ferramenta RGui - Terceiro estudo de caso. 135

APÊNDICE F - Desenvolvimento do conector responsável pela integração das ferramentas RGui e DAVID - Terceiro estudo de caso. 154 


\section{LISTA DE FIGURAS}

Figura 1: Metodologia de desenvolvimento do projeto...................................................................... 4

Figura 2: Exemplo de modelo conceitual (adaptado de [65]) …........................................................ 30

Figura 3: Exemplo de representação usando o Formato de Arquivo do OBO (adaptado de [65])........ 31

Figura 4: Exemplo de representação usando XML ……...................................................................... 32

Figura 5: Exemplo de representação usando a linguagem RDF...................................................... 33

Figura 6: Exemplo de representação usando um diagrama de classe UML ......................................... 34

Figura 7: Exemplo de representação usando linguagem OWL ........................................................... 35

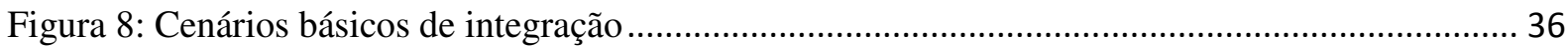

Figura 9: Modelo de descrição detalhada de caso de uso....................................................................... 39

Figura 10: Representação dos dados de entrada e saída do conector .................................................. 40

Figura 11: Mapeamento de conceitos dos modelos conceituais para ontologia de referência .............. 43

Figura 12: Conceitos e relacionamentos associados a ácidos nucleicos ............................................. 48

Figura 13: Conceitos e relacionamentos associados à Expressão Gênica .............................................. 49

Figura 14: Abordagens para análise de expressão gênica .................................................................... 50

Figura 15: Conceitos e relacionamentos entre os tipos de dados de expressão gênica e valores

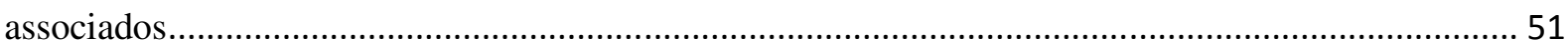

Figura 16: Conceitos e relacionamentos do valor baseado em contagem ............................................. 52

Figura 17: Arquitetura de integração das ferramentas DMV, RGui e TMeV ....................................... 54

Figura 18: Arquitetura de integração de dados BLAST a ferramentas DMV e TMeV .......................... 57

Figura 19: Arquitetura de integração de dados de microarray one-color a ferramentas RGui e DAVID

Figura 20: Diagrama de atividades relacionado ao desenvolvimento do conector $\mathrm{C}_{1}$ (primeiro estudo de caso).

Figura 21: Diagrama de casos de uso relacionado ao desenvolvimento do conector $\mathrm{C}_{1}$ (primeiro estudo

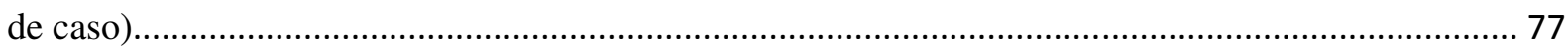

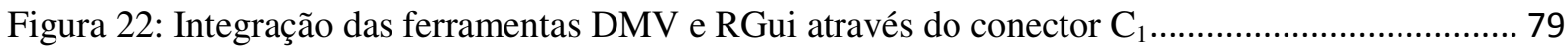


Figura 23: Modelagem conceitual associada à entrada do conector $\mathrm{C}_{1}$ (primeiro estudo de caso)....... 81

Figura 24: Diagrama de classes do conector $\mathrm{C}_{1}$ (primeiro estudo de caso)

Figura 25: Diagrama de atividades relacionado ao desenvolvimento do conector $\mathrm{C}_{2}$ (primeiro estudo de caso).

Figura 26: Diagrama de casos de uso relacionado ao desenvolvimento do conector $\mathrm{C}_{2}$ (primeiro estudo de caso).

Figura 27: Integração das ferramentas $\mathrm{RGui} \mathrm{e} \mathrm{TMeV} \mathrm{através} \mathrm{do} \mathrm{conector} \mathrm{C}_{2}$ 90

Figura 28: Modelagem conceitual associada à entrada do conector $\mathrm{C}_{2}$ (primeiro estudo de caso)....... 92

Figura 29: Diagrama de classes do conector $\mathrm{C}_{2}$ (primeiro estudo de caso)

Figura 30: Diagrama de atividades relacionado ao desenvolvimento do conector $C_{1}$ (segundo estudo de caso)

Figura 31: Diagrama de casos de uso relacionado ao desenvolvimento do conector $\mathrm{C}_{1}$ (segundo estudo de caso).

Figura 32: Integração do banco de dados à ferramenta DMV através do conector $\mathrm{C}_{1}$

Figura 33: Representação da integração do banco de dados à ferramenta DMV através dos conectores $\mathrm{C}_{1.1}, \mathrm{C}_{1.2}$ e $\mathrm{C}_{1.3}$

Figura 34: Modelagem conceitual associada à entrada do conector $\mathrm{C}_{1.1}$ (segundo estudo de caso).... 107

Figura 35: Modelagem conceitual associada à saída do conector $C_{1.1}$ (segundo estudo de caso) ....... 107

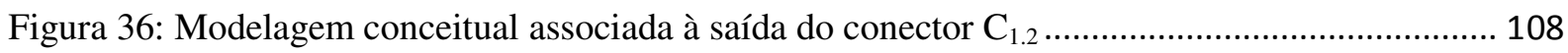

Figura 37: Modelagem conceitual associada à saída do conector $\mathrm{C}_{1.3}$ (segundo estudo de caso)....... 108

Figura 38: Adição do conceito Total_Sampled_Gene_Amount na ontologia de referência......

Figura 39: Ontologia de referência revisada

Figura 40: Diagrama de classes dos conectores simples

Figura 41: Diagrama de atividades relacionado ao desenvolvimento do conector $\mathrm{C}_{2}$ (segundo estudo de caso)

Figura 42: Diagrama de casos de uso relacionado ao desenvolvimento do conector $\mathrm{C}_{2}$ (segundo estudo de caso).

Figura 43: Integração das ferramentas DMV e TMeV através do conector $\mathrm{C}_{2}$

Figura 44: Modelagem conceitual associada à saída do conector $\mathrm{C}_{1.2}$ 
Figura 45: Modelagem conceitual associada à saída da ferramenta DMV .

Figura 46: Modelagem conceitual associada à saída do conector $C_{2}$ (segundo estudo de caso) ......... 130

Figura 47: Diagrama de classes do conector $\mathrm{C}_{2}$ (segundo estudo de caso)

Figura 48: Diagrama de atividades relacionado ao desenvolvimento do conector $\mathrm{C}_{1}$ (terceiro estudo de caso)

Figura 49: Diagrama de casos de uso relacionado ao desenvolvimento do conector $\mathrm{C}_{1}$ (terceiro estudo de caso)

Figura 50: Integração do banco de dados à ferramenta RGui através do conector $\mathrm{C}_{1}$

Figura 51: Dados de entrada e saída associados aos conectores $\mathrm{C}_{1.1}$ e $\mathrm{C}_{1.2}$ (terceiro estudo de caso) 142

Figura 52: Modelagem conceitual associada à entrada do conector $\mathrm{C}_{1}$

Figura 53: Modelagem conceitual associada à saída do conector $\mathrm{C}_{1.1}$

Figura 54: Diagrama de classes dos conectores simples

Figura 55: Diagrama de atividades relacionado ao desenvolvimento do conector $\mathrm{C}_{2}$ (terceiro estudo de caso)

Figura 56: Diagrama de casos de uso relacionado ao desenvolvimento do conector $\mathrm{C}_{2}$ (terceiro estudo de caso)

Figura 57: Integração das ferramentas RGui e DAVID através do conector $\mathrm{C}_{2}$

Figura 58: Modelagem conceitual associada à entrada do conector $\mathrm{C}_{2}$

Figura 59: Modelagem conceitual associada à saída do conector $\mathrm{C}_{2}$

Figura 60: Diagrama das classes implementadas e utilizadas pelo conector $\mathrm{C}_{2}$ (segundo estudo de caso) 


\section{LISTA DE TABELA}

Tabela 1: Descrição dos dados de saída relacionados à funcionalidade $\mathrm{DMV}_{13}$

Tabela 2: Mapeamento dos conceitos associados à entrada e à saída do conector $\mathrm{C}_{1}$ (primeiro estudo de caso) aos conceitos da ontologia de referência

Tabela 3: Descrição dos dados relacionados à saída da funcionalidade $R_{5}$ e à entrada do conector $C_{2} 91$

Tabela 4: Mapeamento dos conceitos associados à entrada e saída do conector $\mathrm{C}_{2}$ (primeiro estudo de caso) aos conceitos da ontologia de referência

Tabela 5: Descrição dos dados de entrada do conector $\mathrm{C}_{1.1}$

Tabela 6: Descrição dos dados de saída do conector $\mathrm{C}_{1 .}$

Tabela 7: Descrição dos dados de saída do conector $\mathrm{C}_{1.2}$ 105

Tabela 8: Descrição dos dados de entrada relacionados à funcionalidade $\mathrm{DMV}_{1}$ 106

Tabela 9: Mapeamento dos conceitos associados à entrada e à saída do conector $\mathrm{C}_{1.1}$ (segundo estudo de caso) aos conceitos da ontologia de referência

Tabela 10: Mapeamento revisado dos conceitos associados à entrada e à saída do conector $\mathrm{C}_{1.1}$ (segundo estudo de caso) aos conceitos da ontologia de referência.

Tabela 11: Mapeamento dos conceitos associados à entrada e à saída do conector $\mathrm{C}_{1.2}$ (segundo estudo de caso) aos conceitos da ontologia de referência

Tabela 12: Mapeamento revisado dos conceitos associados à entrada e à saída do conector $\mathrm{C}_{1.2}$ aos conceitos da ontologia de referência

Tabela 13: Mapeamento dos conceitos associados à entrada e à saída do conector $\mathrm{C}_{1.3}$ (segundo estudo de caso) aos conceitos da ontologia de referência

Tabela 14: Mapeamento revisado dos conceitos associados à entrada e à saída do conector $\mathrm{C}_{1.3}$ (segundo estudo de caso) aos conceitos da ontologia de referência.

Tabela 15: Descrição dos dados de saída do conector $\mathrm{C}_{1.2}$

Tabela 16: Descrição dos dados relacionados à saída da funcionalidade $\mathrm{DMV}_{13}$

Tabela 17: Descrição dos dados de entrada relacionados à funcionalidade $\mathrm{TMEV}_{1}$ e à saída do conector.

Tabela 18: Mapeamento dos conceitos associados à entrada e saída do conector $\mathrm{C}_{2}$ (segundo estudo de caso) a conceitos da ontologia de referência.

Tabela 19: Mapeamento revisado dos conceitos associados à entrada e saída do conector $\mathrm{C}_{2}$ (segundo estudo de caso) a conceitos da ontologia de referência 
Tabela 20: Descrição dos dados de entrada do conector $\mathrm{C}_{1 .}$

Tabela 21: Descrição dos dados de saída do conector $C_{1.1}$ (terceiro estudo de caso) .......................... 143

Tabela 22: Descrição dos dados de saída do conector $\mathrm{C}_{1.2}$ (terceiro estudo de caso)

Tabela 23: Mapeamento dos conceitos associados à entrada e à saída do conector a conceitos da ontologia de referência

Tabela 24: Mapeamento revisado dos conceitos associados à entrada e à saída do conector a conceitos da ontologia de referência

Tabela 25: Descrição dos dados relacionados à saída da funcionalidade $\mathrm{R}_{5}$ 160

Tabela 26: Descrição dos dados de entrada relacionados à funcionalidade $\mathrm{R}_{1}$

Tabela 27: Mapeamento dos conceitos associados à entrada e à saída do conector $\mathrm{C}_{2}$ (terceiro estudo de caso) aos conceitos da ontologia de referência

Tabela 28: Mapeamento dos conceitos associados a entrada e saída do conector a conceitos da ontologia de referência revisada. 


\section{INTRODUÇÃO}

\subsection{Motivação}

No decorrer dos últimos anos, modernas técnicas de biologia molecular foram desenvolvidas para quantificar fenômenos moleculares. Técnicas, tais como PCR em tempo real, microarrays de DNA complementares (cDNA) ou de oligonucleotídeos e SAGE (Serial Analysis of Gene Expression), possibilitam medir os níveis de expressão de um gene ou de vários genes concomitantemente, presentes em uma população celular específica ou em um tecido.

O termo expressão gênica refere-se ao processo em que a informação codificada por um determinado gene é decodificada em RNA mensageiro e posteriormente em um produto funcional. Teoricamente, a regulação desse processo em qualquer uma de suas etapas, pode levar a uma expressão gênica diferencial em uma determinada célula. A análise da expressão gênica é capaz de revelar defeitos genéticos, bem como informações sobre o funcionamento dos processos que controlam o ciclo celular.

O metabolismo celular é um processo que transforma uma molécula em outra através de uma série de reações químicas. Assim, o produto formado em uma reação será utilizado como substrato para a seguinte, é a chamada via metabólica. Essas transformações são fundamentais para a diferenciação celular possibilitando que cada célula apresente características necessárias para a função que vai exercer. A expressão gênica é a responsável por coordenar direta ou indiretamente esse processo ativando "comandos" para que as células realizem determinadas reações. A regulação é baseada nas informações provenientes do DNA da célula que foram transcritas.

Devido à grande quantidade de dados produzidos constantemente pelas pesquisas em biologia molecular, há uma necessidade crescente de utilizar métodos computacionais e estatísticos cada vez mais sofisticados para analisar esses dados [1]. A bioinformática, ou biologia computacional, é uma disciplina multidisciplinar que envolve profissionais de diversas áreas, tais como biólogos, bioquímicos, médicos, matemáticos, estatísticos e informatas, no desenvolvimento de sistemas computacionais para auxiliar na extração, armazenamento, recuperação, análise e classificação de dados biológicos.

Diferentes ferramentas computacionais vêm sendo desenvolvidas visando auxiliar a análise e interpretação de fenômenos biológicos. Essas ferramentas normalmente 
implementam um procedimento ou algoritmo específico e podem ser desenvolvidas e utilizadas de forma isolada, e.g., ProfCom [2], Synergizer [3], Prophinder [4], BAGET [5], ou como parte de um ambiente integrado de análise e descoberta de conhecimento, e.g., Ambiente para Descoberta de Conhecimento para Biologia desenvolvido pelo Centro de Bioinformática da Universidade de São Paulo (BIOINFO-USP) [6], IMGT-Kaleidoscope [7], Bosque [8]. Normalmente, a utilização conjunta e integrada de uma série de ferramentas em sequência (pipeline de ferramentas) é necessária para produzir os resultados esperados.

Uma das grandes dificuldades para a integração de ferramentas computacionais é lidar com a heterogeneidade estrutural, sintática e semântica dos dados envolvidos. Este tipo de problema é recorrente quando ocorre a integração de diferentes tipos de aplicações biomédicas como, por exemplo, integração de prontuários eletrônicos de pacientes [9] e integração de bases de dados genéticas [10]. A solução de problemas estruturais e sintáticos é relativamente simples, se comparada com a dificuldade decorrente da heterogeneidade semântica dos dados.

A interoperabilidade semântica permite que duas ou mais ferramentas possam ser integradas de forma consistente, de modo a trabalhar conjuntamente, compartilhando informações e um entendimento comum sobre estas informações. Para isso deve haver um consenso sobre as informações que são transmitidas e recebidas por essas ferramentas. Entende-se por integração semântica consistente, o processo em que as informações trocadas na integração não possuam ambiguidades e incompatibilidades e sejam univocamente entendidas e compartilhadas por todas as ferramentas envolvidas [11].

Outro desafio da integração de sistemas computacionais está na integração do fluxo de atividades (fluxo funcional) entre as ferramentas. Normalmente, espera-se que duas ou mais ferramentas que operem de forma integrada não somente atuem sobre um mesmo conjunto de dados, mas também que ao término de uma atividade, uma segunda atividade possa ser executada (automaticamente) em outra ferramenta. Uma abordagem normalmente utilizada para realizar esta integração é através do uso de programas interpretados (scripts) pelo sistema operacional (shell script) ou por um interpretador específico (interpretador PHP, Perl, Javascript, etc). Contudo, problemas de heterogeneidade em termos de plataformas de hardware, sistemas operacionais e linguagens de programação dificultam, quando não comprometem, o reuso e a integração dessas ferramentas. 
Além das dificuldades inerentes à integração de sistemas computacionais, observa-se que muitas vezes os biologistas (biólogos, médicos, farmacêuticos, bioquímicos, etc) envolvidos com a pesquisa em biologia molecular, não possuem os conhecimentos técnicos necessários para efetuar esta tarefa adequadamente. Esses biologistas se vêem compelidos a aprender fundamentos, técnicas e linguagens de programação para resolver um problema biológico, o que é altamente contraproducente. Neste sentido, alguns autores sugerem a necessidade de um paradigma para o desenvolvimento de ferramentas de bioinformática centrado nos biologistas [1], segundo o qual esses consigam se adaptar facilmente às ferramentas de suporte, de modo a focar no entendimento do fenômeno biológico.

\subsection{Objetivos}

O objetivo geral deste trabalho foi investigar o uso de modelos conceituais no suporte à integração semântica de ferramentas de análise de expressão gênica. De forma específica, este trabalho teve por objetivos:

1) investigar o uso de conectores para a integração de ferramentas de análise de expressão gênica;

2) propor uma abordagem baseada em modelos conceituais em geral e ontologias em particular para o desenvolvimento de conectores para suporte à integração de ferramentas de análise de expressão gênica;

3) especificar uma ontologia de domínio para a análise de expressão gênica;

4) aplicar essa abordagem em um conjunto de estudos de caso para a criação de ambientes integrados para a análise de expressão gênica.

\subsection{Metodologia}

Para atingir os objetivos deste trabalho foi necessário realizar estudos bibliográficos sobre diferentes assuntos. Primeiramente foi feito um estudo bibliográfico visando explorar conceitos, técnicas e modelos no domínio de análise de expressão gênica (atividade 1). $\mathrm{O}$ objetivo desse estudo foi obter uma visão geral sobre a diversidade de abordagens disponíveis para geração e análise de dados de expressão gênica, bem como conhecer ferramentas de suporte. Adicionalmente, esse estudo serviu como base para a definição dos estudos de caso realizados neste projeto.

Um segundo estudo realizado foi relacionado à integração de sistemas computacionais (atividade 2). O objetivo desse estudo foi identificar os principais problemas associados ao 
processo de integração, bem como estudar a função de elementos arquitetônicos em geral e a aplicabilidade de conectores em particular na integração de ferramentas computacionais. Assim, esse estudo serviu como base para a definição de uma abordagem para o desenvolvimento de conectores.

Um terceiro e último estudo realizado foi relacionado a ontologias (atividade 3). Esse estudo procurou explorar ontologias disponíveis no domínio de bioinformática, além de conceitos, técnicas, processos e ferramentas de suporte para o desenvolvimento de ontologias. O objetivo inicial desse estudo foi prover uma base para a especificação de uma ontologia de domínio para a análise de expressão gênica. Adicionalmente e de forma complementar aos dois estudos anteriores, este terceiro estudo foi utilizado para a definição da abordagem de integração semântica baseada em conectores (atividade 4).

Finalmente, após a definição da abordagem, estudos de caso envolvendo diferentes cenários de integração foram definidos de modo a aplicar e avaliar a abordagem proposta neste trabalho (atividade 5).

A Figura 1 ilustra as atividades associadas ao desenvolvimento deste projeto, bem como seus principais relacionamentos.

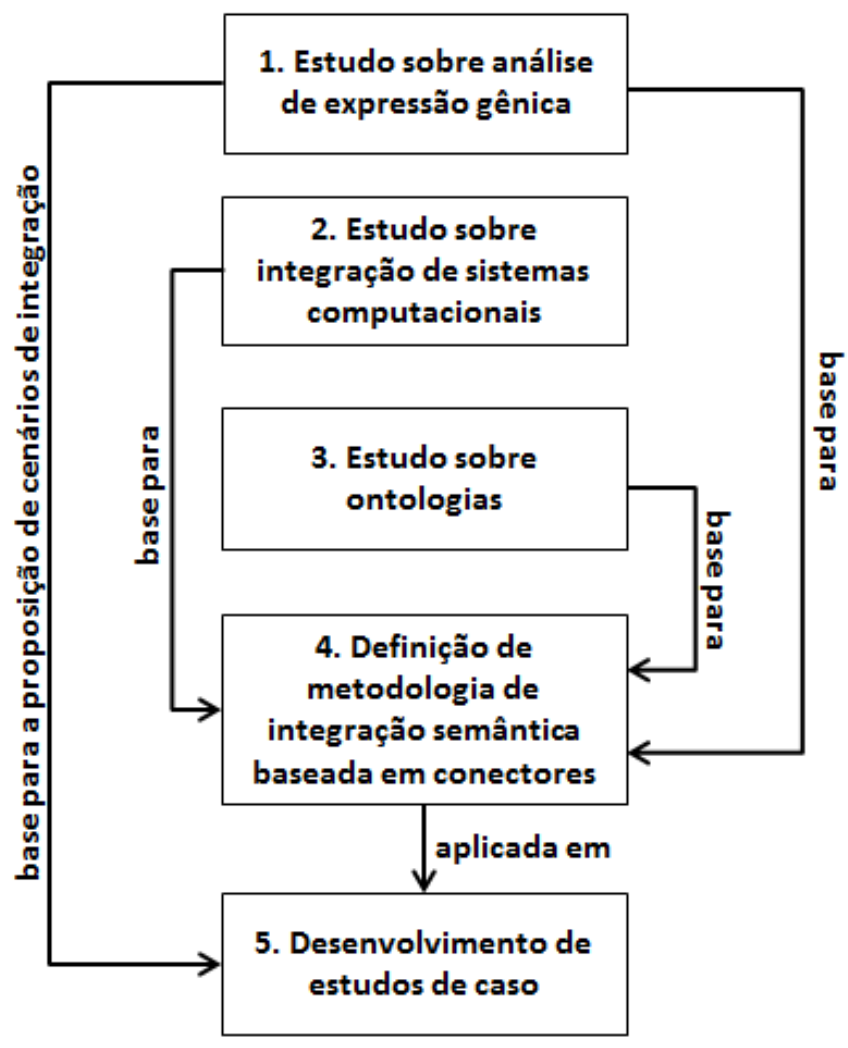

Figura 1: Metodologia de desenvolvimento do projeto 


\subsection{Organização do Documento}

O restante deste documento está organizado da seguinte maneira: o Capítulo 2 apresenta uma visão geral sobre expressão gênica, incluindo abordagens para obtenção dos dados, análise e ferramentas para análise de expressão gênica; o Capítulo 3 apresenta uma visão geral sobre arquitetura e integração de sistemas computacionais, bem como uma discussão sobre os principais desafios relacionados; o Capítulo 4 apresenta uma visão geral sobre ontologias, incluindo aplicações de ontologias na área de bioinformática, integração baseada em ontologias e metodologias de desenvolvimento de ontologias; o Capítulo 5 apresenta a abordagem para a integração semântica de ferramentas de análise de expressão gênica proposta neste trabalho; o Capítulo 6 apresenta uma visão geral dos estudos de caso desenvolvidos para aplicar a abordagem proposta, enquanto que os apêndices A a F apresentam a descrição detalhada dos estudos de caso; finalmente, o Capítulo 7 apresenta as conclusões deste trabalho e sugere alguns trabalhos futuros. 


\section{EXPRESSÃO GÊNICA}

\subsection{Conceitos Básicos}

O ácido desoxirribonucleico (DNA) é um composto orgânico fundamental para a maioria dos seres vivos. Esse composto é formado por duas cadeias longas de unidades básicas denominadas nucleotídeos que se diferenciam pela base nitrogenada: Adenina (A), Guanina (G), Citosina (C) e Timina (T). As cadeias são complementares e pareadas de modo que as bases nitrogenadas estejam associadas: A - T e C - G. A ordem como essas bases aparecem nessa cadeia é denominada "sequência do DNA". Esta sequência armazena as informações genéticas que irão coordenar o desenvolvimento e o funcionamento das funções vitais dos seres vivos [12].

As principais funções designadas ao DNA são armazenar as informações genéticas e possibilitar processos como a replicação e transcrição ou síntese de RNA (ácido ribonucleico). A replicação é o processo de duplicação da informação que está contida no DNA. Já na transcrição ocorre a síntese de moléculas de RNA que são complementares a uma molécula molde de DNA [13] na presença de RNA-polimerase. Esse último está vinculado a um importante processo denominado expressão gênica.

A expressão gênica é um fenômeno biológico regulado por uma complexa rede de interações entre diversas moléculas como DNA, RNA e proteínas. Esse fenômeno consiste em um processo que envolve desde a decodificação da informação que está contida em determinado gene até a formação de um produto funcional como uma proteína (polipeptídeo) ou parte de uma proteína.

Os genes são segmentos de DNA que armazenam informações genéticas importantes aos seres vivos por suas atribuições funcionais. As informações desse segmento contêm apenas um molde para o processo de tradução dessas informações baseado no código genético para formação de um polipeptídeo. O código genético relaciona um tripleto (três nucleotídeos) à formação de seu aminoácido correspondente. Dessa forma, uma sequência linear de aminoácidos irá constituir as proteínas que serão derivadas da informação inicial contida nos genes. Assim, é possível obter um produto gênico funcional (proteína ou RNA) por meio da tradução da informação que está contida no gene e decodificada em um polipeptídeo. 
Apesar de existirem raras exceções, as células constituintes do organismo carregam a mesma informação genética, o DNA. Contudo os genes que são expressos e o nível de expressão dos genes dessas células são distintos. Dessa forma, as células passam por processos de diferenciação em características e funções através da expressão gênica diferencial, mesmo tendo como origem uma informação genética em comum. Em suma, os pesquisadores que estudam a expressão gênica possuem interesse na regulação desse processo através de interceptação da transcrição e da análise dos dados obtidos por técnicas especializadas. Assim, é possível descobrir, por exemplo, a expressão gênica diferencial entre duas amostras [14].

\subsection{Abordagens Para Obtenção de Dados de Expressão Gênica}

Denomina-se genômica funcional a área de pesquisa cujo objetivo é estudar as funções gênicas através da medição simultânea e em larga escala (normalmente milhares) dos níveis de expressão gênica de um genoma [14]. Diferentes técnicas podem ser escolhidas para obter essas medidas. Essas técnicas diferem-se pela tecnologia e/ou abordagem utilizadas na medição da expressão gênica sendo classificadas em: técnicas baseadas em hibridização, técnicas baseada na sequência e demais abordagens.

As técnicas que possuem como fundamento básico a hibridização são baseadas no procedimento em que duas fitas de DNA/RNA emparelham-se caso sejam complementares. A maioria dessas técnicas é de larga escala e baixo custo (salvo algumas exceções como as abordagens de alta resolução e/ou aquelas que utilizam genomas grandes) e normalmente utiliza-se um cDNA marcado com fluorescência. As técnicas de hibridização mais comuns são Northern Blot [15], cDNA Macroarray [16], microrray de DNA[17] e Tiling array [18], sendo as duas últimas as mais importantes em experimentos de larga-escala.

O microarray de DNA [17] é uma técnica que realiza a quantificação simultânea dos níveis de expressão gênica utilizando o processo de hibridização específica. O procedimento básico do microarray envolve inicialmente a extração de RNA das amostras biológicas que estão sob estudo. O RNA é então copiado e marcado com nucleotídeos fluorescentes. Essa amostra de RNA marcado é então hibridizada (ligada) aos cDNAs ou oligonucleotídeos complementares imobilizados nas lâminas de microarrays. As lâminas são então lavadas para a remoção dos RNAs não hibridizados e analisadas em um scanner apropriado. Este aparelho possui uma fonte de luz que excitará os RNAs fluorescentes hibridizados, de modo que a intensidade da fluorescência emitida é proporcional à medida da expressão gênica [14]. 
As técnicas de microarray de DNA podem ser divididas em duas categorias: hibridização one-color e hibridização two-color. A primeira categoria realiza hibridização de uma amostra para cada microarray, marcada com único fluoróforo. A segunda utiliza duas amostras que serão comparadas, marcadas com diferentes fluoróforos (Cy3 e Cy5) e hibridizadas em único microarray. Posteriormente é feita a análise das intensidades relativas de cada fluoróforo [19].

O Tiling array [18] é uma técnica que emprega princípio semelhante ao de microarrays tradicionais. Contudo, as aplicações dessa técnica vão além da medição dos níveis de expressão de RNA a fim de revelar funções e dinâmicas dos cromossomos em larga escala. Essa técnica utiliza marcadores e fragmentos de material genético em estudo que serão hibridizados a sondas fixadas sobre uma superfície sólida. Esses fragmentos são fabricados para o estudo visando cobrir todo o genoma ou regiões do genoma de interesse.

O Tiling array consiste na hibridização do material em estudo com as sondas. $\mathrm{O}$ objetivo da técnica é detectar empiricamente a expressão de transcritos que inicialmente não são conhecidos ou não foram preditos, visando a caracterização de elementos funcionais do material em estudo. $\mathrm{O}$ fato de estudar uma sequência de DNA inteira, mesmo sem ter conhecimento da existência do gene, possibilita descobertas de novas sequências transcritas e elementos de regulação que não foram previstos. Dessa forma, experimentos de Tiling array possibilitam um melhor entendimento dos processos fundamentais dos organismos ou até mesmo a descoberta de novos processos ainda desconhecidos aos pesquisadores.

A abordagem baseada em sequência de DNA procura determinar diretamente a sequência do cDNA em estudo. Essa abordagem possui algumas desvantagens se comparada com a hibridização, por ser de baixo rendimento e alto custo. Essas desvantagens resultaram em uma limitação do uso de técnicas baseadas em sequência de DNA no processo de sequenciamento do cDNA. Contudo, as metodologias atuais visam contornar esses problemas, de modo que esse tipo de abordagem vem sendo cada vez mais utilizado. As principais técnicas associadas são ESTs [20], SAGE [21], MPSS [22] e o RNA-Seq [23], sendo SAGE e RNA-Seq as mais adequadas para quantificação dos níveis de expressão.

O RNA-Seq [23] é uma técnica revolucionária para estudo de transcriptomas. Esta técnica possui alta capacidade de sequenciamento de DNA e possibilita o mapeamento e quantificação dos transcriptomas. O RNA-Seq utiliza tecnologia de sequenciamento em profundidade cujo objetivo é determinar a sequência e o nível de expressão do DNA ou RNA 
celular. Em geral, RNA é convertido em uma biblioteca de cDNA com adaptadores anexados a uma ou ambas as extremidades. Cada molécula é então sequenciada por métodos de larga escala para obtenção de pequenas sequências. Após o sequenciamento, o resultado é alinhado ao genoma ou transcrito de referência. Assim, é possível produzir um mapa de transcrição que consiste na estrutura transcricional e/ou nível de expressão de cada gene.

A conversão de RNAs em uma biblioteca de cDNA é um importante processo que o RNA-Seq realiza. Nesse processo, os adaptadores são adicionados a cada fragmento de cDNA e uma curta sequência é obtida a partir de cada cDNA utilizando uma tecnologia de sequenciamento em larga escala. As sequências resultantes são alinhadas com alguma referência e então classificadas em três tipos: exônico, junções de leitura e cauda poli(A). A partir da classificação em um desses três tipos é então gerado um perfil de expressão para cada gene mostrando, a partir de determinada posição do nucleotídeo, o nível de expressão do RNA [23].

A análise serial da expressão gênica (SAGE) [21] é um método desenvolvido para possibilitar a análise rápida, detalhada, quantitativa e simultânea de um grande número de transcritos (ordem de milhares). SAGE fornece meios para realizar a comparação e a catalogação quantitativa dos genes expressos e os classifica em três categorias de acordo com o resultado de sua análise: normal, em desenvolvimento ou doente. A base para esse método está no uso de pequenas sequências de nucleotídeos (cerca de 9-10 pares de bases que contenham informações suficientes para identificar um único transcrito) e na junção dessas sequências curtas permitindo a análise dos transcritos de forma serial. A análise é feita através da quantificação da frequência de observação do transcrito associando a um nível de expressão correspondente.

Entre as demais abordagens que não se enquadram em nenhuma das anteriores encontra-se o método de PCR em tempo real (qPCR) [24]. Este método possui potencial para detectar e realizar análise quantitativa em alto rendimento de sequências específicas de genes com precisão, rapidez, acurácia e sensitividade comparado aos demais métodos. O objetivo do qPCR é combinar diversos ciclos de amplificação do DNA (aumento da quantidade de material de um alvo específico) com a detecção dos produtos gerados. Como resultados são gerados dados com informações quantitativas proporcionais à detecção de DNAs, cDNAs ou RNAs. A quantificação é baseada na detecção de mudança de fluorescência que altera 
conforme o produto é acumulado na amplificação. Esta mudança é acompanhada a cada ciclo o que possibilita a análise de informações gráficas que são geradas em tempo real.

\subsection{Análise de Expressão Gênica}

Atualmente observa-se que a obtenção de dados relacionados à expressão gênica, auxiliada por diversas ferramentas, superou a capacidade de analisá-los. Existem diferentes ferramentas abertas ou proprietárias que podem ser utilizadas para realizar diferentes tipos de atividades de análise dos dados de expressão gênica $[14,25]$. Ao final deste processo, tem-se como resultado uma lista de valores de genes (diferencialmente) expressos ou valores absolutos do nível de expressão dos genes de uma amostra. Contudo, na maioria das vezes, os dados obtidos através de uma dada técnica de medição de expressão gênica necessitam de algum pós-processamento para possibilitar uma análise coerente. Dessa forma o maior desafio para os biologistas está na interpretação dos dados para obter um melhor entendimento de um determinado fenômeno biológico como conhecer o papel de um conjunto de genes controlador desse fenômeno $[14,25]$. Este processo envolve uma série de atividades relacionadas à interpretação dos dados e das informações obtidas por ferramentas que realizam a quantificação ou qualificação do nível de expressão gênica.

As principais atividades relacionadas ao processo de análise de expressão gênica incluem a normalização dos dados, cálculo do score do gene, identificação de genes diferencialmente expressos, construção de redes regulatórias de genes, agrupamentos por perfis de expressão, exploração e filtragem de um subconjunto de dados a partir de determinada característica, classificação de amostras, edição e criação de alinhamentos, acesso comum a dados de genoma, anotação/classificação da função de um determinado gene, definição, construção e visualização de vias de sinalização e vias metabólicas, entre outros. Alguns desses serviços serão apresentados com mais detalhes a seguir.

A normalização é um procedimento que realiza processamento dos dados buscando corrigir prováveis erros embutidos nos dados. Dessa forma o objetivo da normalização é possibilitar a análise e a comparação de valores dos dados de expressão gênica de diferentes amostras realizando ajustes nos dados para minimizar erros relacionados a efeitos técnicos. Os efeitos técnicos são derivados de variações que não são decorrentes de variações na expressão gênica entre amostras ou entre dados de uma mesma amostra [14]. Existem diversos métodos de normalização como Lowess [26], Cubic Splines [27] e Wavelets [28]. Cada método possui características específicas que o faz ser mais adequado para determinada 
abordagem. Assim, a partir de qual abordagem de obtenção dos dados foi utilizada é recomendado ou até mesmo imprescindível que determinado método de normalização seja aplicado nesses dados. Em geral, as ferramentas que realizam o pré-processamento dos dados realizam a normalização dos dados. Exemplos de ferramentas incluem R/Bioconductor [29], RGui [30] e GeneTrailExpress (GTEX) [31].

A filtragem de um conjunto de dados possibilita ao usuário selecionar um subconjunto de dados a partir de um critério pré-estabelecido. Esse critério pode ser, por exemplo, um valor de threshold escolhido pelo usuário. Dessa forma é possível explorar os dados resultantes que serão apenas um subconjunto dos dados iniciais filtrados por possuírem uma característica definida. Podemos citar o DMV [32], GeneSifter [33], plugins do Excel, Spotfire [34] e R/Bioconductor [29] como exemplos de ferramentas que provêem suporte a esta atividade.

O cálculo do score do gene é uma atividade na qual é feita uma associação de cada gene a um valor de score calculado por diversos métodos (teste-t, média geométrica de $p$ values, entre outros). Partindo desse valor é possível realizar uma classificação do gene em diferentes categorias, como é feito, por exemplo, na análise baseada pelas curvas ROC fazendo um ranking do score de cada gene. Exemplo de ferramentas que provêem suporte a esta atividade incluem R/Bioconductor [29], GeneSifter [33], GeneTrailExpress [31], ErmineJ [35] e plugins do Excel.

Outra atividade bastante utilizada é a identificação dos genes diferencialmente expressos e a identificação dos genes que possuem correlação através dos perfis de expressão que apresentam. Essa identificação pode ser realizada por meio de diversos testes estatísticos como o teste t. Dessa forma, é possível agrupar genes correlacionados e diferenciar quais os genes são expressos e se estes genes são expressos de forma igual. Outra possibilidade está em determinar se os genes podem ser clusterizados em uma mesma categoria funcional. R/Bioconductor [29], ErmineJ [35], TMeV [36] são exemplos de ferramentas que fornecem suporte a essa atividade.

A clusterização e classificação de amostras também são serviços que possibilitam discriminar amostras patológicas de amostras normais partindo de uma característica prédeterminada [37]. Quando se deseja associar categorias de genes a categorias funcionais a partir de dados utiliza-se a clusterização. Dessa forma é possível obter agrupamentos de perfis de expressão gerando uma classificação. Existem diferentes metodologias de clusterização e 
classificação no processo de análise de dados de expressão gênica que podem ser divididos em duas categorias: métodos supervisionados e métodos não supervisionados [14].

Os métodos supervisionados são normalmente utilizados para encontrar genes com níveis de expressão significativamente diferentes entre grupos de amostras e/ou para encontrar genes que corretamente predizem uma característica da amostra (análise de expressão gênica diferencial). Um exemplo de método supervisionado inclui o método de análise do vizinho mais próximo. Os métodos não supervisionados são utilizados para tentar encontrar estruturas ou relacionamentos internos entre o conjunto de dados total ao invés de tentar predizer uma característica. Exemplos de métodos não supervisionados incluem clusterização hierárquica e redes de relevância. Exemplos de ferramentas de clusterização incluem Spotfire[34], GeneSifter [33], TMeV [36], GeneTrailExpress [31] e ErmineJ [35].

A construção de redes regulatórias de genes também é outra atividade bastante utilizada na análise de expressão gênica. As redes são construídas, por inferência, principalmente para correlacionar uma via (pathway) a um determinado gene. Dessa forma é possível inferir a estrutura de uma rede regulatória considerando os valores quantitativos obtidos do nível de expressão de um gene. O nível de expressão de um gene pode depender tanto do seu próprio valor bem como dos valores de expressão de outros genes em tempos anteriores. TMeV [36], Ingenuity System Pathway Analisys [38] e Inferelator [39] são exemplos de ferramentas que realizam essa atividade.

Outra atividade bastante utilizada na análise de expressão gênica é o acesso aos dados de genoma. Diferentes ferramentas disponibilizam bases de dados integrados com informações biológicas sobre o genoma e pathways metabólicos, e servem como uma base de conhecimento de referência para interpretação biológica de dados gerados por experimentos relacionados à análise de expressão gênica. Dessa forma, é possível acessar, comparar, compartilhar e analisar as informações que estão contidas e compartilhadas nesses bancos de dados. Exemplos de ferramentas que disponibilizam bancos de dados genômicos incluem KEGG [40], Biocyc [41], IMGT [7], Bosque [8] e MiMiR [42].

A edição e a criação de alinhamentos é uma atividade que permite que sequências sejam modificadas e posteriormente alinhadas umas às outras. $\mathrm{O}$ alinhamento consiste na comparação de sequências de nucleotídeos em estudo a uma base de dados de sequências já conhecidas buscando similaridades entre elas. Cada ferramenta disponibiliza um processo que realiza um cálculo de pontuação específico para o alinhamento em estudo e, a partir dessa 
pontuação, é possível identificar as sequências que mais se assemelham às da base de dados de referência. Esse serviço está disponível pela ferramenta Blast [43], ClustalW [44], Bosque $[8]$.

Diferentes ambientes integrados para análise de dados de expressão gênica estão disponíveis, por exemplo, IMGT-Kaleidoscope [7], GeneTrailExpress [31], Bosque [8] e MiMiR [42]. Contudo, a maior parte das aplicações são independentes. Isso reforça a necessidade de integração de ferramentas de modo a facilitar o processo de análise por usuários biologistas e até mesmo os usuários de ambientes integrados se beneficiariam com a integração de outras ferramentas, possivelmente complementares, para análise de dados de expressão gênica. 


\section{INTEGRAÇÃO DE SISTEMAS COMPUTACIONAIS}

Com o aumento do número de ferramentas e funcionalidades desenvolvidas e disponibilizadas na área da computação foi necessário aprimorar o processo de desenvolvimento de sistemas computacionais. Assim, esse processo passa a ser elaborado visando evitar o retrabalho e minimizar custos como alocação de recursos pessoais, financeiros e tempo.

O reuso a partir da integração de códigos e/ou serviços passou a ser uma abordagem cada vez mais frequente e importante no processo de desenvolvimento. Existem diversos fatores que contribuíram para a popularização dessa abordagem, tais como: o número crescente de ferramentas desenvolvidas, a disponibilidade do código fonte de algumas ferramentas para reuso e aprimoramento, o aumento na complexidade do desenvolvimento das ferramentas, o aperfeiçoamento da arquitetura de sistemas e a necessidade de redução dos custos.

\subsection{Desafios da Integração de Sistemas Computacionais}

Um sistema computacional é normalmente desenvolvido segundo alguma abordagem sistemática de modo que o sistema seja construído ao longo de várias etapas. Estas etapas são definidas baseadas em algum modelo ou paradigma de desenvolvimento. Exemplos de paradigmas de desenvolvimento incluem desenvolvimento em cascata, desenvolvimento espiral, desenvolvimento incremental, etc.

Grande parte das pesquisas em engenharia de software nos anos 70 e 80 teve como foco o desenvolvimento de notações, técnicas e ferramentas para suporte às atividades de projeto e implementação definidas nestes modelos. Ao longo dos anos 80 e 90, a necessidade de desenvolver sistemas cada vez mais complexos e com recursos cada vez mais limitados contribuiu para o surgimento de novas abordagens de desenvolvimento de software, tais como a orientação a objetos e o desenvolvimento baseado em componentes. Essas abordagens possuem como característica o desenvolvimento com foco no reuso e na integração de código e/ou serviços.

O desenvolvimento de sistemas computacionais a partir do reuso e da integração de (partes de) aplicações existentes é uma atividade cada vez mais utilizada. O crescimento foi motivado pelo aumento da complexidade dos requisitos dos sistemas, pela diminuição do 
tempo de desenvolvimento, dos recursos humanos e financeiros disponíveis nas organizações, pela exigência da maior qualidade do sistema como um todo, entre outros.

Existem situações em que as necessidades dos usuários não conseguem ser atendidas por uma ferramenta isolada. Nessas circunstâncias, os usuários necessitam de ferramentas de apoio integradas para obter funcionalidades complementares visando obter o resultado esperado. Diversos cenários de integração são possíveis através do reuso de aplicações existentes. Os cenários podem envolver a integração de funcionalidades específicas de ferramentas distintas. Nesse caso algumas funcionalidades de uma ferramenta podem ser agregadas a outra ferramenta de modo que elas se complementem e gerem um resultado esperado. Existem cenários que envolvem a integração de dados, em que o resultado gerado (dados) por uma ferramenta é utilizado como entrada para a outra.

Os cenários de integração devem ser planejados e elaborados para que o usuário possa obter um resultado confiável e, além disso, evitar que erros/problemas ocorram em todo o processo de integração. Por isso, os usuários e desenvolvedores de sistemas estão em constante busca pela melhor forma de reutilizar (partes de) aplicações sem comprometer o resultado final gerado. Contudo a integração de (partes de) sistemas para construir um novo sistema não é uma tarefa trivial. Diferentes problemas podem ser identificados no processo de integração. Problemas de baixo nível envolvem, principalmente, incompatibilidades entre linguagens, plataformas e bases de dados dos sistemas envolvidos. Exemplos comuns de problemas desse grupo [45]:

- necessidade de modificar pacotes e/ou ferramentas externas e de reescrever funções e procedimentos existentes. Esse problema está relacionado a incompatibilidades entre os sistemas que serão integrados. Em muitos casos, os sistemas não foram previamente projetados para serem integrados e necessitam de adaptações. Dessa forma há uma necessidade de realizar atividades complementares como modificar pacotes ou funções já existentes para possibilitar a integração;

- código resultante extenso, complexo e com baixo desempenho operacional. Pode ser decorrente de modificações efetuadas. O código gerado pode ser um problema, pois é difícil fazer manutenção e ser compreendido. Além disso, esse código pode conduzir a um baixo desempenho operacional, muito menor que o desempenho das mesmas ferramentas trabalhando separadamente; 
- alta possibilidade de introdução de erros. No processo de integração de sistemas existe a possibilidade de ocorrer erros ao alterar ou inserir alguma nova função. À medida que o processo de integração é realizado, o sistema torna-se mais complexo, o processo de modificação e/ou adaptação do sistema é mais custoso e a probabilidade de ocorrência de erros é maior.

Existe outro tipo de problema que pode ocorrer mesmo quando os sistemas foram desenvolvidos utilizando uma mesma linguagem e uma mesma plataforma operacional. Esses problemas são comuns no processo de integração e são classificados como problemas de alto nível. As principais causas desses problemas são devido ao chamado desalinhamento arquitetônico (architectural mismatch), ou seja, um conjunto de pressuposições feitas por (partes de) uma aplicação sendo reutilizada acerca da estrutura da nova aplicação que será construída. Exemplos destas pressuposições incluem [45]:

- suposições sobre qual componente deverá controlar a sequência de processamento;

- suposições sobre como o ambiente irá manipular os dados gerenciados por um componente;

- suposições sobre os padrões de interação entre os componentes;

- suposições sobre o tipo de dado comunicado;

- suposições sobre a infraestrutura de comunicação;

- suposições sobre a presença ou ausência de determinados elementos de processamento e conexão;

- suposições sobre a ordem segundo a qual componentes devem ser instanciados e combinados no sistema como um todo.

Para lidar com esses problemas a integração deve buscar a interoperabilidade sintática e semântica. A interoperabilidade sintática garante que os dados possam ser lidos e reutilizados por todas as ferramentas envolvidas no processo de integração. A interoperabilidade semântica garante que os dados, além de lidos, serão entendidos. Essa garantia se deve a um entendimento comum definido sobre as informações que são transmitidas e recebidas no processo de integração [11].

\subsection{Arquitetura de Sistemas Computacionais}

A área de arquitetura de sistemas computacionais surgiu como uma necessidade de atuação dentro da área de engenharia de software. A arquitetura desenvolveu-se com enfoque 
na descrição da arquitetura de sistemas computacionais complexos e no uso dessa descrição como base para a definição e análise de requisitos, projeto, implementação, reuso, integração de sistemas e atividades de gerência de software em geral [46].

Diferentes definições de arquitetura de sistemas podem ser encontradas na literatura. Por exemplo, Shaw et al. [47] definem arquitetura como um conjunto de componentes e as interações entre estes componentes. Perry e Wolf [46] definem arquitetura de sistemas como um conjunto de elementos arquitetônicos combinados de uma determinada forma. Esses elementos serão aprofundados na seção 3.3.

A arquitetura de um sistema geralmente é definida por uma descrição em alto nível de abstração, através da especificação dos componentes que o constitui e das interações existentes entre os mesmos. Assim, o estudo da arquitetura permite uma análise elaborada da estrutura ou um conjunto de estruturas de um sistema utilizando o desmembramento do sistema em componentes. Também é possível analisar as propriedades de cada componente do sistema, além dos relacionamentos e comunicação entre eles.

A demanda por sistemas complexos e de qualidade em ambientes heterogêneos vem crescendo continuamente. Concomitantemente, o número de requisitos identificados é cada vez maior embora o cronograma e o orçamento permaneçam restritos. Dessa forma o estudo da arquitetura de sistemas oferece sua contribuição ao processo de desenvolvimento de sistemas computacionais por meio das informações definidas no projeto arquitetônico.

A descrição da arquitetura de um sistema computacional permite uma análise geral, a qual possibilita a integração, o cálculo de custo de manutenção, o desenvolvimento do projeto arquitetônico para o aperfeiçoamento de código e sistema com qualidade, a realização da avaliação da qualidade do código considerando o uso de métricas e o entendimento dos componentes do sistema e seus inter-relacionamentos. Além disso, a descrição da arquitetura de um sistema computacional também é utilizada para assegurar que requisitos não funcionais, tais como desempenho, segurança, confiabilidade, robustez e usabilidade, estejam presentes no sistema [48].

O projeto arquitetônico de um sistema computacional abrange uma série de aspectos estruturais, tais como a forma de organização e arquitetura geral do sistema, protocolos de comunicação e sincronização, atribuição de funcionalidades a componentes do projeto, escalabilidade e desempenho, alternativas de projeto. Tais informações servem de apoio para compreender melhor os requisitos dos usuários, para estimar custos e para facilitar o processo 
de reuso de aplicações. O projeto também oferece informações que possibilitam avaliações aprimoradas sobre consistência e dependência entre sistemas [46]. Assim, é possível realizar o processo de integração de sistemas de forma mais eficiente e confiável com base nas informações contidas no projeto arquitetônico.

Contudo, apesar dos benefícios gerados pelo desenvolvimento do projeto arquitetônico de sistemas, muitos desenvolvedores não conferem a devida importância ao este projeto. Muitos sistemas não possuem projetos arquitetônicos desenvolvidos, enquanto outros são desenvolvidos de forma ad hoc e informal. Com isso, o desenvolvimento do sistema acaba enfrentando problemas, tais como a subutilização devido à má compreensão do mesmo, a impossibilidade de realizar análises do sistema com coerência ou completude, a arquitetura assumida no projeto inicial não ser fidedigna com a evolução do sistema e a falta de ferramentas para auxiliar os projetistas de arquitetura com suas tarefas [49].

Com o intuito de prover suporte para o desenvolvimento de sistemas computacionais, a partir de descrições de alto nível das arquiteturas destes sistemas, surgiram as chamadas linguagens de descrição de arquiteturas (Architectural Description Languages- ADLs). Em geral, o objetivo dessas linguagens é oferecer suporte para o desenvolvimento de sistemas baseados em arquiteturas, utilizando-se das notações formais. As linguagens devem prover uma semântica precisa a fim de evitar ambiguidades e inconsistências nas descrições geradas [50].

Diferentes linguagens de descrição de arquitetura podem ser encontradas na literatura. Exemplos de ADLs incluem Acme [49], Aesop [51], C2 [52] e Darwin [52]. Cada uma dessas linguagens oferece capacidades distintas para o desenvolvimento arquitetônico e posterior análise dos sistemas computacionais em desenvolvimento. Contudo, a integração entre as diversas linguagens é limitada, dado que estas foram desenvolvidas e operam isoladamente das demais.

Acme [49] é uma linguagem de descrição de arquitetura simples e genérica que possui como foco a interconexão arquitetônica predominantemente a nível estrutural. Essa linguagem pode ser utilizada como base para o desenvolvimento de novos projetos arquitetônicos e de novas ferramentas de análises, visando a interconexão de ferramentas que realizam design de arquitetura. Além disso, Acme visa disponibilizar um formato padronizado para uma variedade de ferramentas de arquitetura que apresentam similaridades entre elas. 
Aesop [51] é uma linguagem para o desenvolvimento de ambientes arquitetônicos cujo foco está na especificação de estilos. Entre os estilos arquitetônicos existentes estão a arquitetura em camadas, arquitetura baseadas em objetos e em eventos, e arquitetura centrada em dados. Essa linguagem geralmente é utilizada para prover uma padronização da descrição de arquiteturas buscando direcionar o trabalho dos arquitetos de software no desenvolvimento de sistemas.

C2[52] é uma linguagem de descrição de arquitetura voltada para sistemas distribuídos e dinâmicos. Uma especificação de C2 pode ser caracterizada por uma rede de componentes concorrentes que trabalham conjuntamente através de conectores [53].

Darwin [52] é uma linguagem focada em arquiteturas de sistemas altamente distribuídas cuja dinâmica pode ser modelada por uma estrutura formal definida por essa linguagem. Assim como as demais linguagens, Darwin é utilizada na descrição da arquitetura do sistema através da definição de seus componentes e relacionamentos.

Cada ADL possui características específicas que podem ser mais adequadas para determinadas arquiteturas e também fornecer soluções para problemas específicos. Apesar das diferenças entre as ADLs com relação a definições, características, nível de abstração, notação, etc., há um relativo consenso em relação aos elementos necessários para a descrição de uma arquitetura. Em geral, uma ADL deve modelar explicitamente os componentes, os conectores e a estrutura de interconexão do sistema (configuração arquitetônica) [52].

\subsection{Elementos Arquitetônicos}

Segundo Perry e Wolf [46] a arquitetura de sistemas é composta por elementos arquitetônicos. Existem três diferentes tipos desses elementos que podem ser identificados: elementos de processamento, elementos de dados e elementos de conexão. Os elementos de dados representam as informações que serão utilizadas no processamento. Os elementos de processamento são responsáveis pela transformação dos elementos de dados. Os elementos de conexão são utilizados para conectar e integrar os elementos de dados e processamento em uma mesma estrutura.

Os elementos arquitetônicos são formados por componentes e conectores. Os componentes são representações dos elementos de processamento ou armazenamento de dados (ferramentas, bases de dados, servidores, entre outros). Os conectores são elementos arquitetônicos de conexão utilizados para modelar as interações entre componentes e as regras que controlam essas interações [45]. Exemplos de conectores incluem variáveis 
compartilhadas, entradas de tabelas, buffers, instruções para compiladores, chamadas de procedimento, parâmetros de inicialização, pipes UNIX, estruturas de dados dinâmicas, sequências de chamadas do sistema, etc [47].

Os conectores são construídos a partir de primitivas básicas para transferência de controle e transferência de dados [54]. Conectores podem ser simples, tipicamente implementados em linguagens de programação, ou complexos, compostos a partir de conectores simples, acrescidos de uma arquitetura interna com capacidade de processamento e armazenamento de informação. Os conectores complexos normalmente combinam múltiplas formas de interação.

Outra classificação dos conectores é feita de acordo com os serviços de interação providos. Neste sentido, quatro diferentes tipos de serviços podem ser identificados [54]: comunicação, coordenação, conversão e facilitação. Serviços de comunicação são utilizados para a transmissão de dados entre componentes. Serviços de coordenação são utilizados para a transferência de controle entre componentes. Serviços de conversão são utilizados para transformar a interação provida por um componente na interação requerida por outro componente. Tais serviços são necessários para permitir que componentes heterogêneos e/ou incompatíveis possam interagir uns com os outros, evitando assim problemas de desalinhamento arquitetônico. Finalmente, serviços de facilitação são utilizados para facilitar e otimizar as interações entre componentes. Esses serviços são utilizados para prover, por exemplo, balanceamento de carga, escalonamento e controle de concorrência, de modo a oferecer suporte a requisitos não funcionais e reduzir o acoplamento entre componentes.

Um dado tipo de conector pode prover um ou mais serviços de interação. Por exemplo, uma chamada de procedimento provê tanto serviços de comunicação quanto serviços de coordenação. Conectores de acesso a dados, os quais permitem o acesso a um conjunto de dados mantidos por componente de armazenamento de dados, podem prover tanto serviços de comunicação quanto serviços de conversão. Conectores de adaptação provêem tipicamente serviços de conversão no modelo e/ou protocolo de comunicação ou transformações nos dados. 


\section{ONTOLOGIAS}

\subsection{Introdução a Ontologias}

O crescente aumento de informações geradas na área biomédica tem dificultado o uso e o gerenciamento dessas informações. A busca por informações relevantes é um processo complicado e oneroso quando ocorrem resultados indesejados e/ou até mesmo quando há perda de resultados relevantes. Dessa forma é necessária a adoção de técnicas mais elaboradas para permitir a extração e o uso de forma eficiente do conhecimento contido nos dados.

A modelagem conceitual é uma área de pesquisa multidisciplinar que visa a representação de um domínio de interesse independentemente das escolhas de projeto e das tecnologias utilizadas, já que estas poderiam influenciar na construção de um sistema computacional [55]. Modelos conceituais são utilizados para prover um melhor entendimento das abstrações de um determinado domínio, bem como para facilitar a comunicação entre usuários, projetistas e demais interessados. Além disso, modelos conceituais também são utilizados como base para o processo de desenvolvimento de software.

Outros benefícios da modelagem conceitual incluem a disponibilização de dados científicos de forma que eles sejam facilmente encontrados e recuperados, o compartilhamento de um entendimento comum a fim de permitir o reuso de um determinado domínio, a realização de métodos de apoio à decisão, o oferecimento de dados, entre outras [55].

Diferentes tipos de modelos conceituais e abordagens para a criação de modelos conceituais podem ser encontrados na literatura. Ontologias representam um tipo de modelo conceitual que tem ganhado destaque crescente nos últimos anos. Na ciência da computação, as ontologias foram inicialmente associadas à área de inteligência artificial [55]. Contudo, as ontologias não permaneceram restritas a essa área, mas estão presentes em outras áreas, tais como gerência de conhecimento [56], sistemas de informação [57], tecnologias web (web semântica) [58] e engenharia de software [59, 60].

Muitas áreas de aplicação já se beneficiam com o uso de ontologias, desde sistemas de processamento de linguagem natural até sistemas de raciocínio e suporte a decisões. A utilização de ontologias ganha notoriedade no domínio das ciências biológicas uma vez que provê suporte semântico tanto para termos e conceitos existentes quanto para novas definições 
da área. Além disso, esse domínio dispõe de um vasto repertório de informações para estudo e pesquisa.

Segundo Gruber [61], uma ontologia é definida como uma especificação explícita de uma conceituação. Conceituação é uma descrição formalizada dos conceitos e suas relações. Neste sentido, uma ontologia é uma descrição formal dos conceitos e dos relacionamentos existentes em um determinado domínio. Genericamente uma ontologia é um modelo conceitual que representa um conjunto de conceitos relacionados a um domínio e os relacionamentos entre eles. Uma ontologia deve determinar os termos usados para descrever e representar um domínio de conhecimento através da definição de indivíduos, classes, atributos e relacionamentos.

Alguns autores argumentam que ontologias e modelos conceituais são artefatos distintos, diferindo uns dos outros em função principalmente da generalidade das ontologias [62], i.e., modelos conceituais tendem a ser mais específicos e próximos à implementação, e de seu escopo de (re)utilização [60], enquanto ontologias normalmente abrangem um número potencial de projetos maior do que um modelo conceitual. Contudo, no contexto deste trabalho essa distinção não é relevante, uma vez que modelos conceituais podem ser desenvolvidos com diferentes objetivos e a partir de diferentes pontos de vista [63].

Ontologias podem ser classificadas de acordo com seu grau de generalidade. Neste sentido, Guarino [57] propõe uma classificação baseada em três níveis de generalidade. No nível mais genérico estão as ontologias de alto nível, as quais descrevem conceitos genéricos que são independentes de um domínio ou problema em particular. A seguir encontram-se as ontologias de domínio e as ontologias de tarefa, as quais descrevem respectivamente os conceitos relacionados a um determinado domínio e tarefas ou atividades genéricas como especializações dos conceitos introduzidos nas ontologias de alto nível. Por fim, encontram-se as ontologias de aplicação, as quais descrevem conceitos relacionados tanto a um domínio quanto a uma tarefa em particular, como especializações dos conceitos introduzidos nas respectivas ontologias de domínio e tarefa. Normalmente esses conceitos correspondem a papéis desempenhados por entidades do domínio quando ocorre a execução de uma dada atividade.

\subsection{Ontologias em Bioinformática}

Uma das motivações para o uso e desenvolvimento de ontologias na área de bioinformática é a disponibilidade de grande quantidade de dados biológicos. Em geral, as 
ontologias são utilizadas para a padronização, compartilhamento e gerenciamento destes dados. Dentre as possíveis aplicações das ontologias está a representação formal do conhecimento de modo a possibilitar o compartilhamento e o reuso desse conhecimento. $\mathrm{Na}$ área de bioinformática, ontologias têm sido utilizadas, por exemplo, para disponibilizar um modelo de conceitos biológicos que auxiliam na integração de bases de dados e ferramentas heterogêneas da área [50]. Exemplos de ontologias em bioinformática incluem Gene Ontology (GO) [64], Foundational Model of Anatomy (FMA) Ontology [65], Sequence Ontology (SO) [66], Microarray Gene Expression Data Group (MGED) Ontology (MO) [67] e IMGT Ontology [68]. Cada ontologia possui características peculiares e são destinadas a diferentes propósitos.

Gene Ontology (GO) [64] é uma das ontologias mais conhecidas na área. GO tem como objetivo prover um vocabulário sobre genes e seus produtos. Esse vocabulário é dinâmico, controlado e estruturado para que possa ser aplicado a todos os organismos eucariotos. $\mathrm{O}$ vocabulário pode ser utilizado para manutenção dinâmica do genoma e para a interoperabilidade entre bancos de dados genômicos. O GO é composto por três ontologias independentes: processos biológicos, funções moleculares e componentes celulares. A ontologia de processos biológicos refere-se a algum processo físico ou químico relacionado à área biológica com a participação de um gene ou de um produto gênico. A ontologia de funções moleculares está relacionada à descrição das funções moleculares, como as atividades bioquímicas de um produto de gene. Essa ontologia descreve o evento que ocorre sem especificar onde nem quando. Finalmente, a ontologia de componentes moleculares descreve o local da célula onde um produto gênico está ativo.

Foundational Model of Anatomy (FMA) [65] Ontology é uma ontologia utilizada como referência na área de informática biomédica para classificação de entidades anatômicas. Essa ontologia consiste de classes ou tipos e relacionamentos necessários para a representação simbólica de estruturas anatômicas do corpo humano. Essa representação deve ser desenvolvida de modo que seja entendida pelos humanos e interpretada pelos sistemas computacionais. Essa ontologia não é limitada, isto é, ela pode ser expandida e aplicada a uma variedade de espécies. Assim, o objetivo principal da FMA Ontology é oferecer padronização e consistência para o desenvolvimento de representações das estruturas anatômicas. Exemplos de projetos desenvolvidos com base na FMA incluem a ontologia em neuroanatomia [69], ontologia de físicos em biologia [70], semântica que correlaciona a anatomia de ratos 
(próstata e glândulas mamárias) com anatomia humana [71] e uma ontologia de aplicação FMA-RadLex para anatomia radiológica [72].

Sequence Ontology (SO) [66] é uma ontologia que tem como finalidade descrever as características e as propriedades de sequências biológicas. SO disponibiliza um conjunto de termos e relacionamentos para descrever anotações genômicas com o objetivo de padronizar suas diferentes formas de representação. A partir dessas anotações é possível extrair conhecimento e possibilitar o raciocínio automatizado sobre o seu conteúdo. Dessa forma os processos de troca de dados e análises comparativas de anotações podem ser facilitados.

Microarray Gene Expression Data Group (MGED) Ontology (MO) [67] foi desenvolvida para disponibilizar uma terminologia para anotações de dados de microarray. Além disso, MO oferece uma semântica que possibilita anotações de um experimento de microarray através de um mecanismo consistente para descrever experimentos de genômica funcional. Esse mecanismo consiste em descritores biológicos relacionados às amostras ou ao processamento das mesmas. MO não tenta incorporar termos de ontologias existentes, mas faz referência a outras ontologias, facilitando o reuso de outras ontologias relacionadas a dados de microarray.

O padrão "Minimal Information for the Annotation of a Microarray Experiment" (MIAME) [73] foi concebido para auxiliar no processo de descrição de experimentos de microarray. Este padrão consiste da definição de um conjunto de informações mínimas necessárias para permitir a interpretação de resultados e reprodução de experimentos de microarray. MO provê os termos para que essa descrição esteja de acordo com as especificações do MIAME. A descrição é modelada pelo Microarray Gene Expression Object Model (MAGE-OM) e posteriormente traduzida pelo Microarray Gene Expression Markup Language (MAGE-ML) em um formato padrão baseado em XML para facilitar a troca de dados [74].

Devido à popularização e consequente proliferação das ontologias biomédicas, foi necessário gerenciar e coordenar o processo de desenvolvimento e integração dessas ontologias, papel assumido pelo Open Biomedical Ontologies (OBO) Foundry [75]. Essa organização define um conjunto de princípios que oferecem suporte no processo de integração de dados biomédicos. Além disso, OBO Foundry mantém um conjunto de ontologias interoperáveis e bem estruturadas que incorporam vocabulários de diversas representações biológicas. Para que uma ontologia faça parte deste repositório ela deve estar disponível para 
uso sem restrições, ser mutável, estar bem definida sintaticamente (sem ambiguidades), compartilhar informações comuns e ser desenvolvida através de um esforço colaborativo.

Embora não faça parte do OBO Foundry [75], a IMGT-ONTOLOGY [68] é uma ontologia desenvolvida para as áreas de imunogenética e imunoinformática. Esta ontologia define conceitos para minimizar a complexidade da imunogenética e reduzir a distância entre as esferas biológica e computacional em bioinformática. Nessa perspectiva, IMGT Ontology é componente chave na elaboração e criação de conceitos e normas para modelar o sistema imunológico. Os conceitos são derivados de sete axiomas pré-determinados: identificação, descrição, classificação, numeração, orientação, localização e obtenção. A maioria dos conceitos está relacionada com a descrição e a caracterização de componentes das áreas de imunogenética e imunoinformática.

\subsection{Integração Baseada em Ontologias}

Ontologias têm sido utilizadas como suporte ao processo de desenvolvimento de integração de sistemas computacionais. Normalmente sistemas integrados possuem um domínio de conhecimento comum, o qual engloba tanto informações comuns a uma variedade de aplicações relacionadas, quanto informações específicas para cada aplicação. Desse modo as ontologias servem como ferramentas para compartilhar esse conhecimento comum, definido em um domínio de conhecimento, entre as diversas aplicações. Contudo, as ontologias fornecem não só um meio que possibilita a comunicação não ambígua entre os sistemas a serem integrados, mas também servem para que sistemas de domínios distintos possam compartilhar informações.

A integração de sistemas e bases de dados em bioinformática utilizando ontologias pode ser classificada em duas abordagens. Na primeira abordagem, ontologias são utilizadas como base para a definição de um modelo de dados comum a um grupo de ferramentas ou para a definição de um modelo de referência (padrão) para a descrição de conjuntos de dados biológicos. Exemplos do uso dessa abordagem incluem o sistema IMGT [68] e o modelo MAGE-OM [74].

ImMunoGeneTics (IMGT) [68] é um sistema integrado de referência internacional nas áreas de imunogenética e imunoinformática. Esse sistema consiste em um conjunto de bases de dados de genes, sequências genéticas e estruturas de proteínas, além de ferramentas para a análise de sequências, análise genômica e análise de estrutura 3D das proteínas. Tanto as 
bases de dados quanto as ferramentas foram definidas de acordo com a ontologia IMGTONTOLOGY.

Microarray Gene Expression Object Model (MAGE-OM) [74] é um modelo conceitual criado para descrever formalmente a sintaxe e a estrutura de dados de experimentos de microarray. Esse modelo foi inicialmente desenvolvido pela Microarray Gene Expresssion Data (MGED) Society e posteriormente adotado como padrão pelo Object Management Group (OMG) [76]. Com base no MAGE-OM, foi desenvolvida a MGED Ontology (MO) [67] para prover suporte à anotação semântica e busca em bases de dados de experimentos de microarray. MAGE-OM foi traduzido em uma linguagem de marcação MAGE-ML com suporte do MO para fornecer uma plataforma comum com a finalidade de facilitar a troca de dados entre sistemas. Por fim, foi criada a ferramenta MAGE-SKT que é responsável por facilitar a integração do MAGE-ML aos sistemas [74].

Na segunda abordagem, ontologias são utilizadas na construção de mediadores, os quais representam um modelo de dados global (modelo/ontologia de referência). Esses mediadores são (então) utilizados para a integração de diferentes bases de dados e serviços, também chamados de modelos de dados específicos ou locais. Os mediadores provêem serviços que irão determinar como será a interação entre os componentes. Exemplos do uso dessa abordagem incluem os sistemas TAMBIS [77] e ONTOFUSION [78].

Transparent Access to Multiple Bioinformatics Information Sources (TAMBIS) [77] é um sistema que permite o acesso transparente e de forma integrada a múltiplas bases de dados e ferramentas de análise. O sistema tem como base um modelo conceitual de terminologia biológica, i.e., ontologia de domínio, chamada TAMBIS, e modelos das bases de dados sendo integradas. Consultas são feitas com base nos termos definidos na ontologia e assim mapeados para requisições nas respectivas bases de dados.

ONTOFUSION [78] é um sistema que integra bases de dados biomédicas baseado em ontologias. Esse sistema promove a integração de dados (baseados) em dois processos: mapeamento e unificação. No mapeamento, as representações físicas das bases de dados (esquemas físicos) são mapeadas para os chamados esquemas virtuais, i.e., ontologias ou modelos conceituais que representam a estrutura das informações contidas em uma (dada) base de dados. No processo de unificação, diferentes esquemas virtuais são integrados em um único esquema virtual unificado, i.e., uma ontologia que reflete a estrutura conceitual das informações armazenadas nas diferentes bases de dados. 


\subsection{Metodologias de Desenvolvimento de Ontologias}

O desenvolvimento de uma ontologia não é uma tarefa simples. Em geral, essa atividade é realizada ao longo de várias etapas, por meio de um processo colaborativo. $\mathrm{O}$ processo de desenvolvimento de uma ontologia é análogo em muitos aspectos ao processo de desenvolvimento de software. Neste sentido, Hesse [60] propõe um ciclo de vida de quatro fases inspirado em um paradigma de desenvolvimento de software evolucionário: análise, projeto, implementação e uso operacional.

A fase de análise envolve inicialmente a definição do domínio e dos objetivos da ontologia (focado na solução do problema alvo). Segue-se a identificação das possíveis fontes de conhecimento, como por exemplo, lista de possíveis requisitos das aplicações do domínio e outras ontologias relacionadas. Nessa fase é construído um primeiro glossário de termos e são definidas as linguagens a serem utilizadas na especificação da ontologia.

A fase de projeto envolve inicialmente a definição da estrutura, com possível identificação de sub-ontologias. Nessa fase uma ontologia de referência é desenvolvida com o foco na precisão dos conceitos e na eficiência de comunicação desses conceitos entre os membros de uma comunidade [79]. O objetivo principal dessa ontologia é promover o entendimento comum entre pessoas, não máquinas. O glossário de termos é completado nessa fase, aprimorado e estendido com referências cruzadas.

A fase de implementação envolve a tradução da ontologia de referência para uma ontologia concreta utilizando-se uma linguagem de especificação com características de decidibilidade e eficiência computacional de modo a possibilitar atividades de inferência computacional. Alternativamente, a ontologia de referência pode também ser traduzida para uma linguagem de programação.

Finalmente, a fase de uso operacional envolve a utilização efetiva da ontologia desenvolvida, tanto por usuários quanto por diferentes aplicações. A partir das opiniões e sugestões coletadas ao longo do uso da ontologia, uma revisão da ontologia pode ser justificada e um novo ciclo de desenvolvimento pode ser iniciado.

Diferentes metodologias foram propostas para a criação de ontologias [80]. Tais metodologias utilizam diferentes conjuntos de linguagens, artefatos e atividades neste processo de desenvolvimento. Exemplos de metodologias incluem a metodologia de Uschold e King [81], metodologia de Grüninger e Fox [82], METHONTOLOGY [83] e a abordagem de Amaya Berneras [84]. 
A metodologia de Uschold e King [81] é baseada no processo de desenvolvimento de ontologias através da definição de quatro passos. O primeiro passo consiste em identificar qual o propósito da ontologia a ser construída. O segundo passo consiste no processo de construção da ontologia. Nesse passo são identificados os termos e relacionamentos, realizados os processos de codificação e de integração com ontologias existentes. No terceiro passo é feita avaliação da ontologia e, finalmente a documentação.

A metodologia de Grüninger e Fox [82] é baseada principalmente na construção de modelos lógicos de conhecimento. Para desenvolvimento de uma ontologia seis passos são recomendados. O primeiro passo consiste em formular cenários motivadores do processo de desenvolvimento. No segundo passo são formuladas questões relacionadas aos cenários definidos no passo anterior. O terceiro passo consiste em especificar um vocabulário representativo dos cenários utilizando uma linguagem formal. No quarto passo é feita a formalização das questões utilizando o vocabulário definido no passo anterior. No quinto passo são especificados formalmente os termos e regras da ontologia a ser desenvolvida. $\mathrm{O}$ último passo consiste em obter respostas para as questões formalizadas.

METHONTOLOGY [83] é uma metodologia que permite construir ontologias em alto nível de conhecimento. Primeiramente, essa metodologia sugere um planejamento das atividades a serem realizadas. Nesse passo devem ser definidos o processo de desenvolvimento de ontologias e as técnicas que serão utilizadas para realizar cada atividade. Posteriormente, o desenvolvimento é realizado com base nas atividades definidas no primeiro passo. Esse desenvolvimento deve incluir as etapas de especificação, conceitualização, formalização e implementação da ontologia. $O$ último passo consiste em realizar atividades de suporte como integração, avaliação e documentação das ontologias desenvolvidas.

A abordagem de Amaya Berneras [84] está vinculada ao desenvolvimento de ontologias associadas a aplicações. A cada nova aplicação, uma ontologia representativa dessa aplicação deve ser desenvolvida. A ontologia pode reutilizar e integrar ontologias existentes. Para o desenvolvimento da mesma, três passos são recomendados. O primeiro passo é a especificação da nova aplicação. O segundo passo consiste em estruturar a ontologia, reutilizar e estender o que já existe de outras aplicações. Finalmente, o último passo consiste no aprimoramento e na estruturação da ontologia.

O desenvolvimento de uma ontologia assemelha-se ao desenvolvimento de sistemas computacionais também nos aspectos metodológicos, uma vez que as ontologias são partes de 
um sistema. Assim as metodologias de desenvolvimento de ontologias são similares às metodologias de desenvolvimento de sistemas, com algumas adaptações. Entre as similaridades, ambas as metodologias devem considerar aplicações já existentes e reutilizá-las se possível. Além disso, no processo de implementação e uso operacional o feedback do usuário para quem o desenvolvimento está destinado deve ser considerado [60].

\subsection{Linguagens Para Representação de Ontologias}

As ontologias são utilizadas para representação de conceitos de algum domínio de conhecimento. A formalização desses conceitos pode ser realizada utilizando linguagens para representação de ontologias, de modo que os mesmos sejam compreendidos por máquinas e pessoas. Essas linguagens possibilitam estruturar e expressar as informações em sistemas computacionais de forma clara e sem ambiguidades.

Existem diversas linguagens utilizadas para representação das ontologias, tais como OBO File Format [85], XML (eXtensible Markup Language) [86], XML Schema [86], RDF [87] e RDF Schema [87], UML [88, 89] e OWL [90]. Qualquer linguagem escolhida para a construção da ontologia deve representar juntamente com as definições de conceitos, as relações existentes entre os mesmos.

A Figura 2 ilustra um exemplo extraído da Foundational Model of Anatomy (FMA) Ontology usando uma notação gráfica simplificada. De acordo com essa notação, um retângulo representa um conceito e uma seta direcionada representa uma relação entre dois conceitos. Nesse exemplo, todos os relacionamentos existentes entre os conceitos são do tipo "is a" que representa uma especialização de um nó pai em um nó filho. Dessa forma Short bone e Long bone são especializações de Bone organ, enquanto que Femur e Tibia são especializações de Long bone. Esse exemplo será utilizado como base para ilustrar a aplicação de diferentes linguagens para a representação de ontologias, as quais são apresentadas a seguir. 


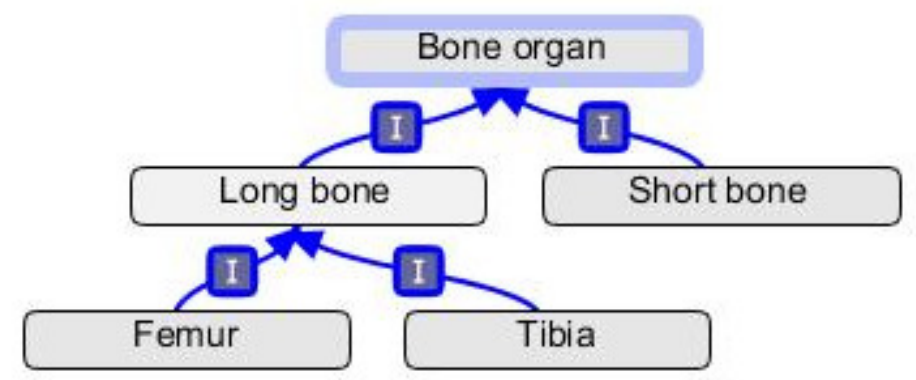

Figura 2: Exemplo de modelo conceitual (adaptado de [65])

\subsubsection{Formato de arquivo do $\mathrm{OBO}$}

OBO File Format [85] é uma linguagem textual de representação de ontologia independente de plataforma, utilizada para visualização e edição de ontologias. Essa linguagem foi planejada para ser facilmente entendida, editável, analisada e extensível com o mínimo de redundância. Inicialmente desenvolvido pelo Gene Ontology Consortium, o OBO File Format é utilizado principalmente na área de bioinformática com a finalidade de armazenar e compartilhar ontologias da área.

A Figura 3 ilustra a representação do modelo descrito na Figura 2 utilizando o formato de arquivo do OBO. Essa representação define cada conceito como uma instância de um termo (palavra-chave Term). Assim, a cada novo conceito uma nova instância de termo deve ser criada. Para cada conceito são definidos os atributos e relacionamentos existentes. Exemplos de atributos incluem a identificação, o nome e a definição do termo. Além dos atributos, relacionamentos podem ser declarados. Para cada relacionamento são declarados o tipo de relacionamento e o conceito (termo) com o qual existe essa relação. Todas as informações contidas entre duas declarações de termo referem-se a um mesmo conceito. 


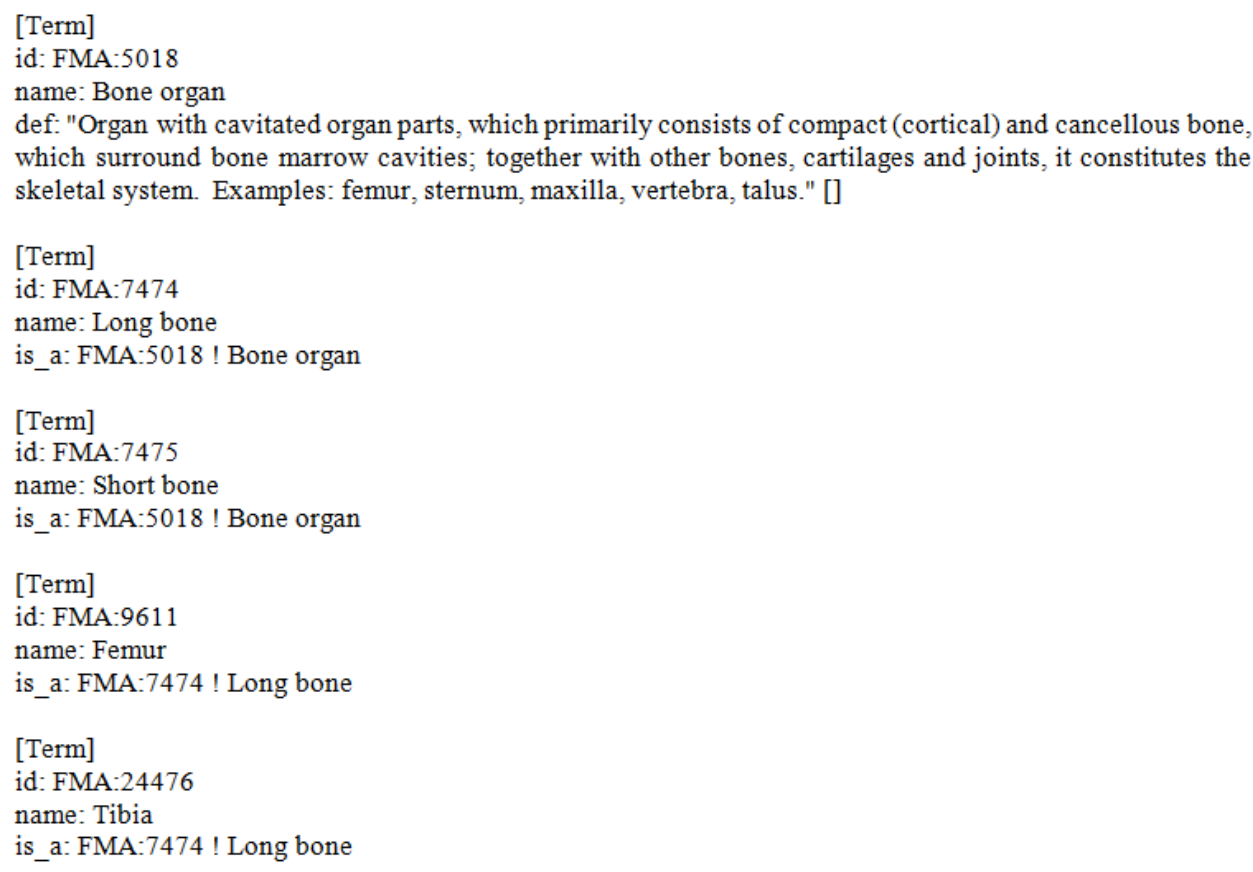

Figura 3: Exemplo de representação usando o Formato de Arquivo do OBO (adaptado de [65])

\subsubsection{XML/Schema XML}

Extensible Markup Language (XML) [86] é uma linguagem de marcação que disponibiliza um formato para a representação de dados de forma estruturada. Desse modo, essa linguagem procura unificar o formato dos dados usados na comunicação entre duas aplicações, além de garantir a codificação em XML de qualquer coisa que possa ser definida na gramática, a chamada expressão universal [11]. Além disso, XML permite que uma mesma informação seja representada de diferentes formas utilizando os recursos da linguagem

Schema XML [11] é uma linguagem baseada no formato XML que disponibiliza um vocabulário para descrição de propriedades e classes de um recurso XML. Essa linguagem define regras para validar a estrutura de um documento XML. As regras podem definir quais elementos, atributos, valores, tipos de dados podem aparecer no documento ou até mesmo definir quais elementos são descendentes de quais elementos.

A Figura 4 ilustra a representação do modelo descrito na Figura 2 utilizando a linguagem XML. Nessa representação cada conceito está definido entre tags, que consistem de palavras entre sinais ' $<$ ' e ' $>$ ', de abertura e fechamento. Toda tag de abertura possui um fechamento associado. A definição de um novo conceito é feita através da criação de uma tag $<$ class-def $>$. Entre a tag de abertura $<$ class-def $>$ e a de fechamento $</$ class-def $>$ são definidos os atributos desse conceito (<class name="value" $>$ ) e relacionamentos (<subclasse-of $>$ ), se 
houver, desse conceito a outro. Cada relacionamento está definido por uma tag <subclass-of> que possui em seu conteúdo, ou seja, até a tag de fechamento </subclasse-of>, a definição do conceito com o qual se relaciona.

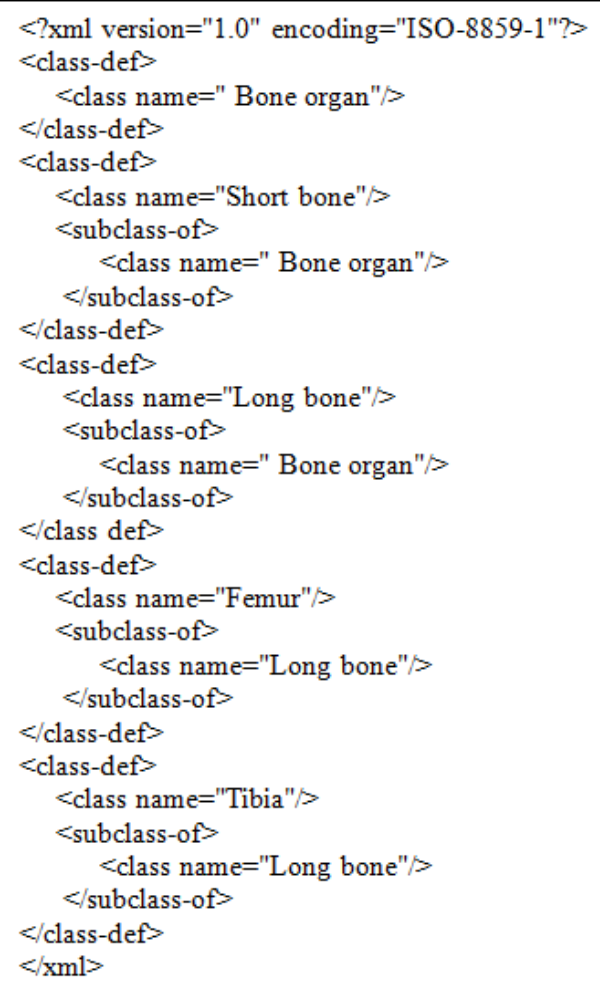

Figura 4: Exemplo de representação usando XML

\subsubsection{Resource Description Framework (RDF)/ RDF Schema}

RDF [87] é uma linguagem de propósito geral baseada em XML usada principalmente para representar informações na Web. Essa linguagem provê recomendações para padronização na definição de metadados e para a representação de dados. A representação de objetos é feita através de notações que determinam um padrão para definição de atributos e valores de modo que os dados possam ser trocados entre aplicações [11]. RDF Schema [87] é uma linguagem que disponibiliza elementos básicos para descrição de ontologias. Essa linguagem também é utilizada na definição de dados para modelos RDF especificando quais objetos podem ser utilizados com quais atributos na representação de dados desses modelos [11].

A Figura 5 ilustra a representação do modelo descrito na Figura 2 utilizando RDF. Essa representação, assim como em XML, utiliza tags para definir conceitos e 
relacionamentos. Para definir um novo conceito, RDF utiliza uma tag <rdf:Class $>$ que possui em seu conteúdo um identificador especificado em $<$ rdfs:ID="value" $>$. O relacionamento de generalização é definido por uma tag de relacionamento < rdfs:subClassOf $>$ que especifica o conceito com o qual se relaciona.

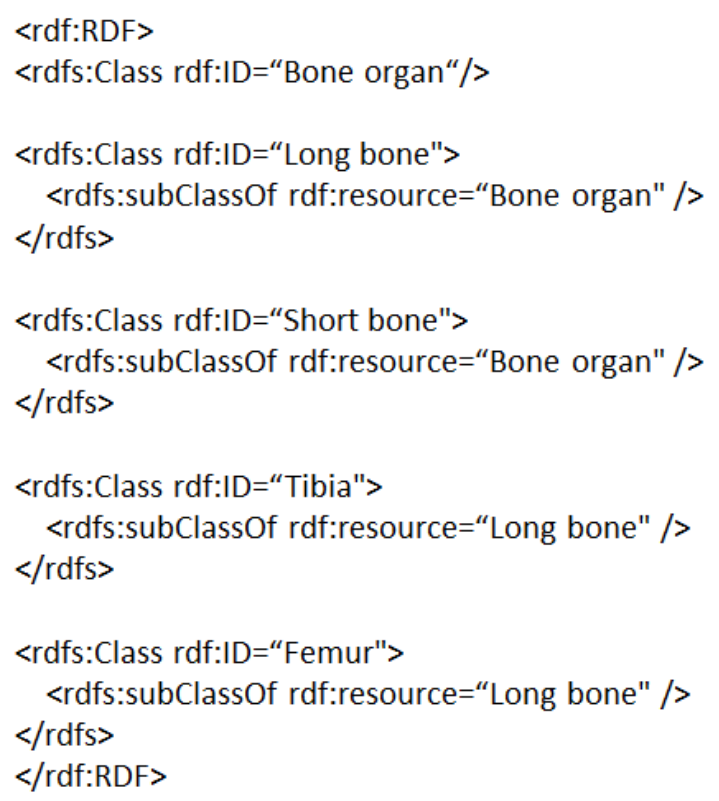

Figura 5: Exemplo de representação usando a linguagem RDF

\subsubsection{Unified Modeling Language (UML)}

Unified Modeling Language (UML) [88, 89] é uma linguagem bastante utilizada na representação de modelos conceituais e ontologias de referência tanto por ser uma linguagem com representação gráfica, com amplo suporte ferramental, quanto por permitir a definição de vocabulários específicos (perfis UML) para a representação de modelos. Essa linguagem foi desenvolvida e padronizada pelo Object Management Group (OMG) para a modelagem de sistemas computacionais orientados a objetos.

UML é definida a partir de uma hierarquia de metamodelagem de quatro níveis. O nível M0 corresponde a objetos em tempo de execução. O nível M1 corresponde a modelos desenvolvidos por usuários e projetistas, por exemplo, em termos de um conjunto de classes. O nível M2 corresponde ao metamodelo UML, isto é, à linguagem propriamente dita. Finalmente, o nível M3 corresponde ao meta-metamodelo UML, isto é, uma linguagem para a definição de linguagens de modelagem, que nesta hierarquia corresponde à linguagem Meta Object Facility (MOF) [91]. 
A Figura 6 ilustra a representação do modelo descrito na Figura 2 utilizando um diagrama de classe UML. Nesse diagrama, cada conceito está representado por um retângulo. Um relacionamento de generalização é representado por uma linha com um triângulo não preenchido ao final. Através dessa representação é possível verificar graficamente cada conceito e os relacionamentos entre eles.

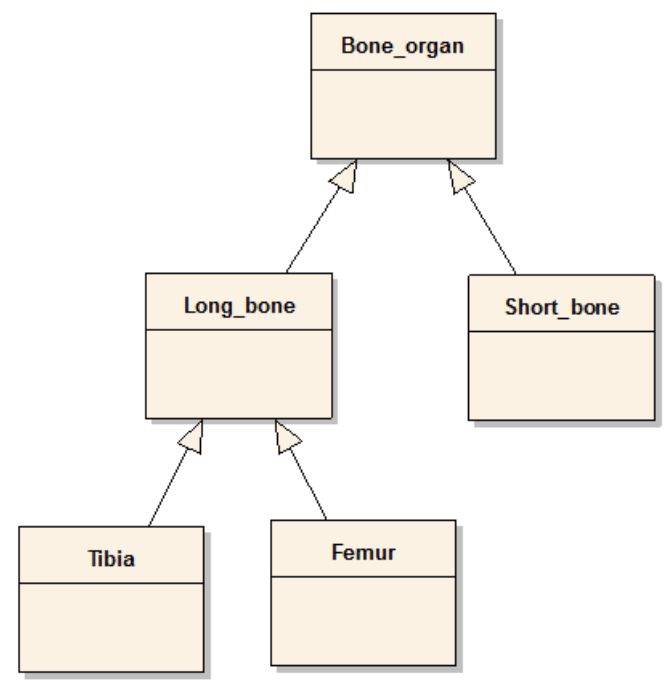

Figura 6: Exemplo de representação usando um diagrama de classe UML

\subsubsection{Web Ontology Language (OWL)}

Web Ontology Language (OWL) [90] é uma das linguagens mais utilizadas para a criação de uma ontologia concreta. A linguagem OWL foi desenvolvida e padronizada pelo World Wide Web Consortium (W3C) para a especificação de ontologias na web. A motivação principal para a criação de OWL foi a necessidade de capturar formalmente o significado da terminologia utilizada em documentos web possibilitando realizar algum processamento sobre os mesmos. Neste sentido, fatores como velocidade de processamento foram priorizados em relação à expressividade da linguagem. OWL pode ser considerada uma família de linguagens dado que OWL provê três sub-linguagens com poder de expressão progressivo: OWL Lite, OWL DL e OWL Full, cada qual uma extensão da linguagem predecessora, respectivamente [92].

Cada uma das três sub-linguagens possui um nível de formalidade e disponibiliza uma liberdade ao usuário para realizar a definição da sua ontologia: OWL Lite é a mais simples e fornece hierarquia de classificação e algumas restrições simples. OWL DL disponibiliza expressividade máxima e garantia de decidibilidade e completude computacional. Oferece 
algumas restrições adicionais comparadas ao Lite. OWL Full fornece expressividade máxima, mas não oferece garantia computacional [92]. Na escolha de uma sub-linguagem devem ser levados em consideração as vantagens de cada uma em relação às demais e o propósito que a linguagem vai ser utilizada.

A Figura 7 ilustra a representação do modelo descrito na Figura 2 utilizando a linguagem OWL. Nessa representação, assim como em XML, também são utilizadas tags para definição de conceitos e relacionamentos. Para cada novo conceito uma tag $<$ Declaration> é definida e possui como conteúdo a declaração de uma classe <Class name="value" $>$, onde value representa o nome da classe. Os relacionamentos são definidos após a apresentação de todos os conceitos. A relação de generalização é definida utilizando a tag < SubClassOf>, onde são especificados os dois conceitos associados a essa relação. Neste caso, o primeiro conceito consiste na subclasse do segundo.

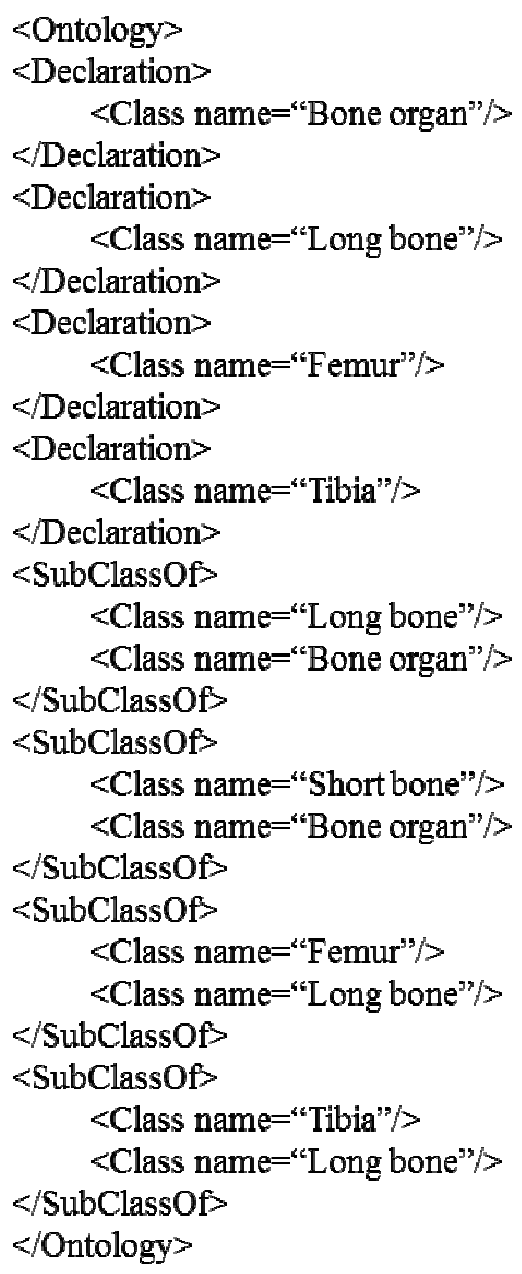

Figura 7: Exemplo de representação usando linguagem OWL 


\section{ABORDAGEM DE INTEGRAÇÃO SEMÂNTICA BASEADA EM CONECTORES}

Este capítulo apresenta uma abordagem para a integração semântica de ferramentas de análise de expressão gênica usando conectores. Esta abordagem consiste de um conjunto de diretrizes que consistem de atividades a serem realizadas para o desenvolvimento de um conector para integrar semanticamente duas ferramentas ou uma fonte de dados e uma ferramenta, bem como de uma ontologia de referência proposta para a área de análise de expressão gênica.

\subsection{Cenários Básicos de Integração}

Uma dada ferramenta $\left(\mathrm{T}_{\mathrm{A}}\right)$ pode ser integrada de diferentes formas a outra ferramenta $\left(\mathrm{T}_{\mathrm{B}}\right)$ ou a uma fonte de dados $(\mathrm{D})$. Neste sentido, cinco cenários básicos de integração podem ser identificados considerando-se apenas o fluxo de dados entre estas entidades (veja Figura 8): i) dados armazenados em $D$ são consumidos por $T_{A}$; ii) dados produzidos por $T_{A}$ são armazenados em $\mathrm{D}$; iii) dados armazenados em $\mathrm{D}$ são consumidos por $\mathrm{T}_{\mathrm{A}}$ e posteriormente dados produzidos por $\mathrm{T}_{\mathrm{A}}$ são armazenados em $\mathrm{D}$; iv) dados produzidos por $\mathrm{T}_{\mathrm{A}}$ são consumidos por $\mathrm{T}_{\mathrm{B}}$; e v) dados produzidos por $\mathrm{T}_{\mathrm{A}}$ são consumidos por $\mathrm{T}_{\mathrm{B}}$ e posteriormente dados produzidos por $\mathrm{T}_{\mathrm{B}}$ são consumidos por $\mathrm{T}_{\mathrm{A}}$.

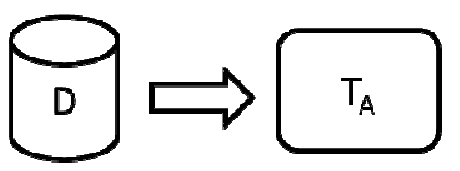

(i)

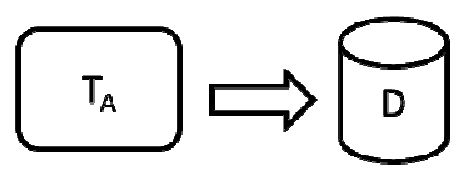

(ii)
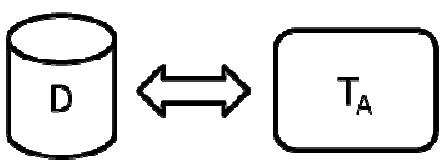

(iii)

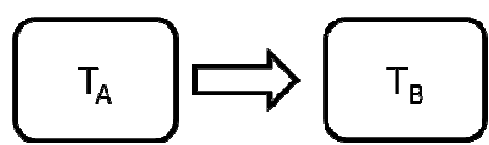

(iv)

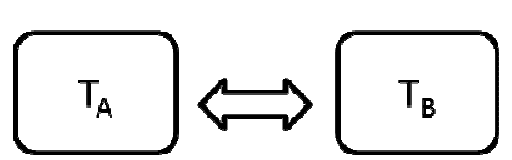

(v)

Figura 8: Cenários básicos de integração

Consideramos que o cenário iii pode ser visto como uma combinação dos cenários i e ii, enquanto que o cenário v pode ser visto como uma variação do cenário iv. Em ambos os casos, há o fluxo bidirecional de dados entre uma fonte de dados e uma ferramenta ou entre 
duas ferramentas. Neste sentido, o conjunto de diretrizes propostos na seção 5.2 levam em consideração apenas os cenários de fluxo unidirecional de dados. Contudo, dado que os cenários iii e v (fluxo bidirecional) representam variações dos cenários i, ii e iv (fluxo unidirecional), as mesmas diretrizes poderão ser aplicadas a estes cenários com pequenas variações.

\subsection{Diretrizes Para Desenvolvimento de Conector}

As atividades abaixo podem ser utilizadas no desenvolvimento de um conector $\mathrm{C}$ para a integração de duas ferramentas A e B ou uma fonte de dados D e uma ferramenta A.

\section{Identificação das principais funcionalidades das ferramentas envolvidas}

Esta atividade tem por objetivo identificar as principais funcionalidades das ferramentas a serem integradas. Estas funcionalidades devem ser especificadas de forma abstrata através da elaboração de documento contendo uma lista $\mathrm{FA}_{1}, \mathrm{FA}_{2}, \ldots, \mathrm{FA}_{\mathrm{N}}$ e $\mathrm{FB}_{1}$, $\mathrm{FB}_{2}, \ldots, \mathrm{FB}_{\mathrm{M}}$ das funcionalidades providas pelas ferramentas $\mathrm{A}$ e $\mathrm{B}$, respectivamente. A partir desta especificação funcional, tem-se uma melhor compreensão dos serviços providos por cada ferramenta e, ao mesmo tempo, uma base para identificar potenciais pontos de interação. Caso a integração seja realizada entre uma fonte de dados e uma ferramenta, devem ser especificadas somente as funcionalidades da ferramenta envolvida.

\section{Descrição inicial do cenário de integração}

Após a identificação das principais funcionalidades providas pelas ferramentas A e B, devemos descrever o cenário de integração a ser considerado no desenvolvimento do conector C. Dado que, em geral, uma ferramenta provê diferentes serviços e considerando-se que os serviços providos por duas ferramentas de interesse podem ser combinados de diferentes formas para a criação de um ambiente integrado para a análise de expressão gênica, tem-se então um conjunto potencialmente grande de possibilidades ou cenários de integração. Neste sentido, esta atividade tem por objetivo delimitar estas possibilidades de modo a descrever o cenário alvo da integração.

A descrição deste cenário pode ser realizada em duas etapas concomitantes. Inicialmente, devemos proceder à seleção das funcionalidades de interesse para o cenário de integração pretendido. Assim, a partir da lista $\mathrm{FA}_{\mathrm{i}}$, e $\mathrm{FB}_{\mathrm{j}}$, das funcionalidades providas pelas ferramentas A e B devemos selecionar o subconjunto das funcionalidades diretamente 
relacionadas ao cenário pretendido. Ao mesmo tempo, devemos realizar uma descrição geral deste cenário. Esta descrição pode ser feita de forma textual e deve, necessariamente, envolver todas as funcionalidades de interesse identificadas. Novamente, caso a integração seja realizada entre uma fonte de dados e uma ferramenta, devem ser selecionadas somente as funcionalidades de interesse da ferramenta envolvida.

\section{Descrição detalhada do cenário de integração}

Após a descrição inicial do cenário de integração, devemos detalhá-lo. Este detalhamento pode ser realizado através do desenvolvimento de diferentes modelos funcionais associados ao cenário de integração. O objetivo desta atividade é detalhar as principais funcionalidades associadas ao cenário de integração, bem como identificar possíveis relacionamentos entre as mesmas. Neste sentido, recomenda-se o desenvolvimento de um modelo de caso de uso e de um modelo de atividades do cenário de integração.

Um modelo de atividades consiste de um diagrama de atividades UML [88,89]. Um diagrama de atividades descreve um comportamento a partir da execução coordenada de uma sequência de atividades. Cada funcionalidade de interesse identificada deve ser mapeada para uma atividade. Além disso, as funcionalidades associadas ao conector também devem ser mapeadas para atividades, pois são essenciais para a integração de duas ferramentas ou de uma ferramenta e uma base de dados. O desenvolvimento desse modelo tem por objetivo prover uma descrição integrada das principais atividades (funcionalidades) do cenário de integração, isto é, sem a preocupação com a vinculação das funcionalidades a suas ferramentas.

Após o desenvolvimento do modelo de atividades, um modelo de caso de uso deverá ser desenvolvido. Um modelo de caso de uso consiste de um diagrama de casos de uso UML $[88,89]$ e de uma descrição detalhada dos casos de uso de interesse. Um diagrama de caso de uso descreve um cenário de interação entre um conjunto de usuários (atores) e um sistema. Essa interação consiste de uma sequência de ações que o sistema executa para produzir um resultado observável para seus usuários.

Os casos de uso serão identificados com base no modelo de atividades desenvolvido e nas funcionalidades associadas ao cenário de integração. De maneira geral, cada atividade identificada pode ser mapeada para um caso de uso. Contudo, duas ou mais atividades relacionadas poderão ser mapeadas para um mesmo caso de uso caso a granularidade das 
mesmas seja baixa. Cada caso de uso identificado estará associado a uma das ferramentas envolvidas na integração ou ao próprio conector. Os atores e suas associações com os casos de uso serão identificados a partir da descrição geral do cenário de integração.

A descrição detalhada dos casos de uso consiste na descrição textual dos principais aspectos associados ao caso de uso. A Figura 9 apresenta o modelo de descrição detalhada de um caso de uso. Para cada caso de uso deverão ser definidos elementos como atores, finalidade e visão geral. Esta descrição também deverá incluir uma descrição numerada das ações iniciadas pelos atores associados ao caso de uso, bem como das ações executadas pela ferramenta em resposta às ações dos atores (sequência típica de eventos). Uma sequência alternativa de eventos também pode ser especificada caso existam ações executadas, tanto pelos atores quanto pelo sistema, que não foram especificadas na sequência típica e que representam possibilidades a serem realizadas no mesmo caso de uso.

\begin{tabular}{|l|l|}
\hline Caso de Uso & Especificar nome do caso de uso $>$ \\
\hline Atores & $<$ Especificar os atores deste caso de uso $>$ \\
\hline Finalidade & $<$ Especificar o propósito deste caso de uso $>$ \\
\hline Visão Geral & $<$ Especificar de maneira geral este caso de uso $>$ \\
\hline
\end{tabular}

Sequência típica de eventos

\begin{tabular}{|l|l|}
\hline \multicolumn{1}{|c|}{ Ação do Ator } & \multicolumn{1}{c|}{ Resposta do sistema } \\
\hline $\begin{array}{l}\text { <specificar ações executada } \\
\text { pelos atores do caso de uso }>\end{array}$ & $\begin{array}{l}\text { <specificar respostas do sistema que } \\
\text { podem ser geradas em decorrência de } \\
\text { alguma ação executada pelos atores do } \\
\text { caso de uso }\end{array}$ \\
\hline
\end{tabular}

Figura 9: Modelo de descrição detalhada de caso de uso

A descrição detalhada dos casos de uso não precisa ser realizada para todos os casos de uso identificados no diagrama, mas apenas para os casos de uso de interesse. O critério para seleção desses casos de uso baseia-se na identificação, a partir do diagrama de atividades, das atividades que estão na região limítrofe, isto é, onde deve ocorrer a interação entre duas ferramentas ou entre uma ferramenta e uma base de dados. Essa região contém as atividades que derivam os casos de uso de interesse os quais devemos detalhar. Além disso, devemos especificar possíveis relacionamentos com outros casos de uso. Ou seja, se houver um caso de uso de interesse que possua algum relacionamento de inclusão ou extensão com outros casos de uso, esses últimos devem ser considerados nessa descrição detalhada. 


\section{Descrição detalhada dos dados de interesse}

Após realizar a descrição detalhada do cenário de integração, devemos realizar uma descrição detalhada dos dados de interesse da integração. Os dados de interesse da integração representam os dados de entrada para o conector que podem ser produzidos por uma ferramenta (ou outro conector) ou armazenados em uma fonte de dados. Além disso, os dados de interesse representam os dados de saída do conector que podem ser consumidos por uma ferramenta (ou outro conector) ou armazenados em uma fonte de dados.

Para realizar a descrição dos dados de interesse devemos primeiramente identificar as funcionalidades $\mathrm{F}_{\mathrm{i}}$ diretamente relacionadas à produção ou ao consumo destes dados. Essas funcionalidades podem ser identificadas a partir da descrição detalhada do cenário de integração, tipicamente associadas aos casos de uso de interesse. Para cada funcionalidade $F_{i}$ identificada, devemos descrever os dados associados a partir da descrição detalhada do cenário de integração. Outras fontes de informações também poderão ser utilizadas no desenvolvimento desta atividade tais como manuais, páginas de ajuda (help) ou qualquer documentação da ferramenta que permita realizar um levantamento de informações sobre os dados que são consumidos ou produzidos.

A Figura 10 ilustra os dados de interesse associados a cada funcionalidade que devemos descrever. Apesar dos dados de interesse serem representados pelos dados de entrada do conector $\left(\mathrm{SFA}_{\mathrm{i}}\right)$ e de saída do conector $\left(\mathrm{EFB}_{\mathrm{j}}\right)$, podemos também identificar os demais dados associados às funcionalidades identificadas $\left(\mathrm{EFA}_{\mathrm{i}}, \mathrm{SFB}_{\mathrm{j}}\right)$. Embora esta identificação possa auxiliar na identificação dos dados de interesse, a mesma não é obrigatória.

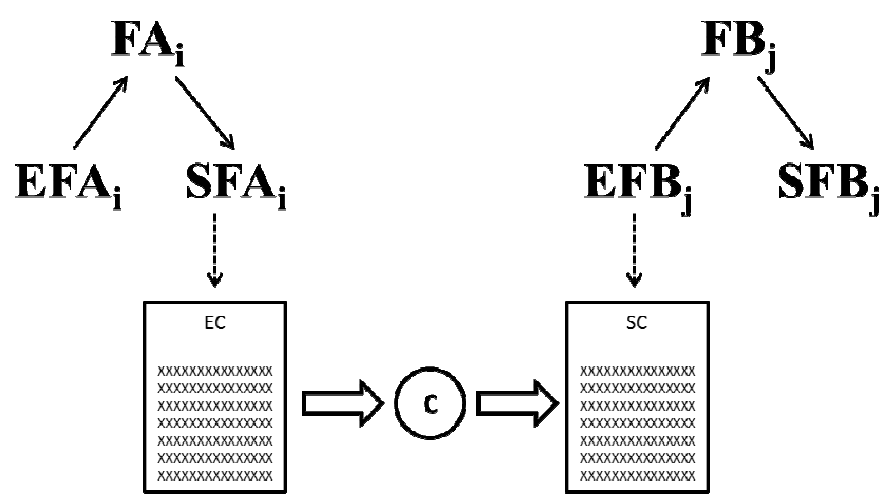

Figura 10: Representação dos dados de entrada e saída do conector 
Existem situações em que o conector é responsável por realizar mais de uma atividade de processamento dos dados, podendo ser considerado como um conector composto. Nestes casos, o conector pode ser decomposto em conectores simples, cada qual responsável por realizar uma atividade específica do processamento dos dados. Dessa forma os dados associados à entrada e à saída de cada um desses conectores simples são considerados de interesse e devem ser descritos assim como os dados associados às funcionalidades.

O formato para descrição de dados consiste de duas tabelas, uma para representação dos dados consumidos e outra para os dados produzidos por cada conector. Assim, para cada novo item de dado identificado, uma linha na tabela é criada. As colunas devem especificar o nome/identificação do item de dado, a descrição semântica do dado e a sintaxe de representação do mesmo. A descrição semântica consiste em uma descrição textual sobre a representação dos dados identificados. A sintaxe de representação consiste em informar o formato de representação (e.g., arquivo texto, arquivo binário, banco de dados, etc), tipo de dado (e.g., inteiro, ponto flutuante, String) e cardinalidade (e.g., única instância, vetor, matriz). Ao final desta atividade temos a descrição detalhada dos dados de interesse utilizados na integração.

\section{Modelagem conceitual dos dados de interesse}

Após a descrição detalhada dos dados de interesse devemos desenvolver um modelo conceitual utilizando diagramas de classe UML $[88,89]$ para representar os dados de interesse envolvidos na integração. O objetivo desta atividade é produzir um modelo abstrato a partir das informações contidas na descrição detalhada realizada na atividade 4. A linguagem UML foi escolhida para criar os modelos conceituais pois trata-se da mesma linguagem utilizada na modelagem da ontologia de referência. Além disso, essa linguagem facilita a criação de modelos concretos dos dados em uma futura implementação envolvendo o domínio representado.

Dois modelos conceituais devem ser especificados para cada conector a ser desenvolvido: um modelo conceitual para representar os dados de entrada do conector e outro para representar os dados de saída do conector. Em cada modelo conceitual devem ser formalizados os conceitos e os relacionamentos fundamentais identificados na descrição detalhada dos dados. Cada item de dado deve ser mapeado para um conceito do modelo 
conceitual. No caso de um conector composto, devem ser especificados dois modelos conceituais para cada conector simples que o compõe.

\section{Mapeamento para ontologia de referência}

Após a modelagem conceitual dos dados de interesse devemos realizar o mapeamento dos conceitos identificados em cada modelo conceitual para uma ontologia de referência. Primeiramente devemos identificar os conceitos semanticamente equivalentes nos conjuntos de dados de interesse da integração. Assim é possível identificar conceitos associados a ferramentas distintas e que são mapeados para um mesmo conceito da ontologia de referência. Essa identificação é uma atividade fundamental para a integração semântica entre duas ferramentas ou entre uma ferramenta e uma fonte de dados. Caso não haja equivalência ou uma forma de obter-se essa equivalência entre esses conjuntos de dados, a integração semântica fica comprometida.

O mapeamento pode ser realizado utilizando-se uma tabela de equivalência para cada conector. Essa tabela contém três colunas: a primeira coluna contém conceitos referentes aos dados consumidos pelo conector; a segunda coluna contém os conceitos presentes na ontologia de referência; e a terceira coluna contém os conceitos referentes aos dados produzidos pelo conector. Cada entrada nas colunas 1 e 3 da tabela devem ser mapeadas para um conceito da ontologia de referência. A Figura 11 ilustra a construção de uma tabela de equivalência. 


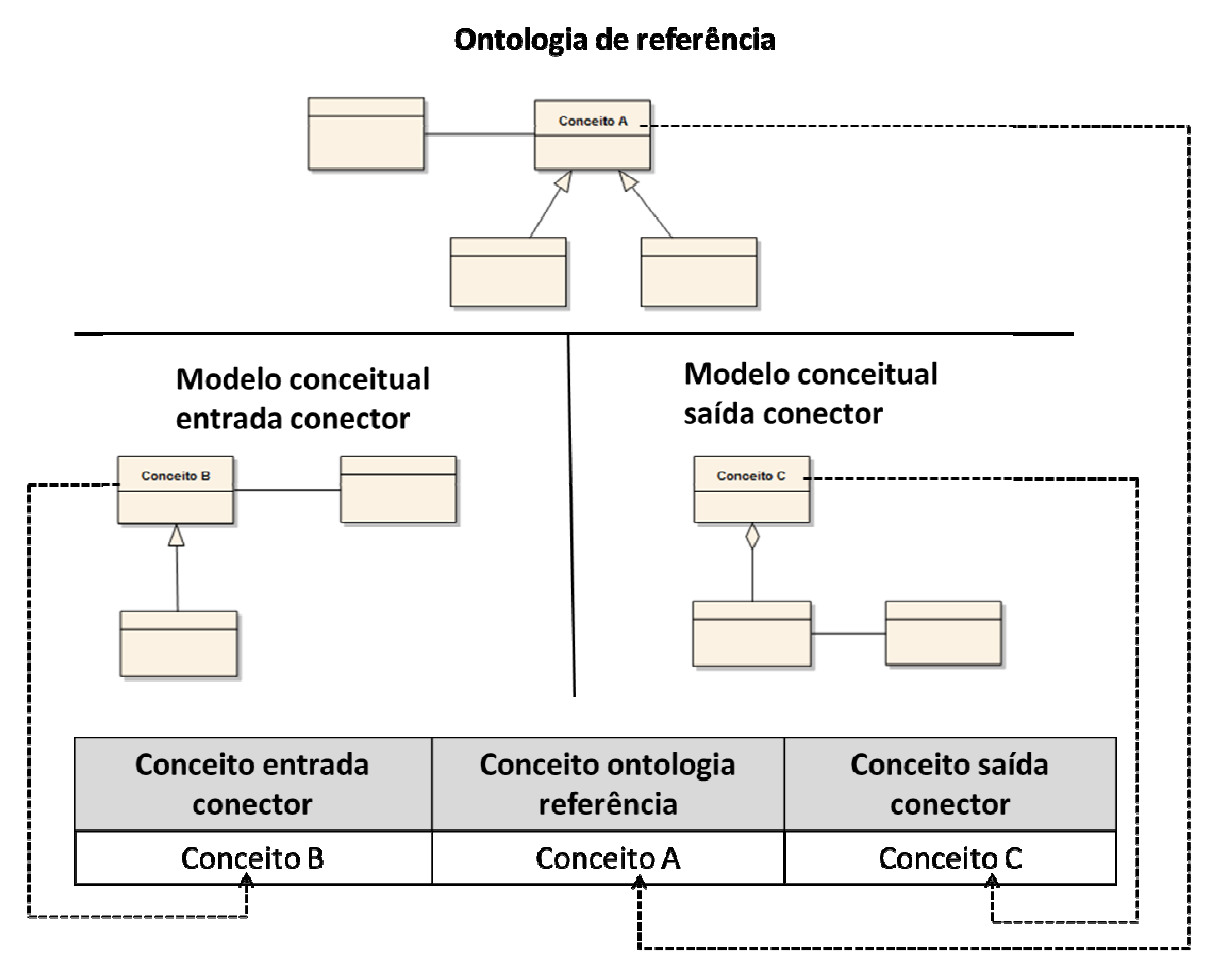

Figura 11: Mapeamento de conceitos dos modelos conceituais para ontologia de referência

De forma ideal, ao final do mapeamento, cada conceito representando um dado consumido pelo conector é mapeado para um conceito da ontologia de referência, o qual também representa um dado produzido pelo conector. Contudo, podem existir situações em que um conceito que representa dados de entrada consumidos pelo conector não possui equivalência com um conceito que representa a saída. Além disso, podem existir situações em que um conceito que representa os dados de saída produzidos pelo conector não encontra equivalência em uma entrada consumida pelo conector.

Ambos os casos podem não representar necessariamente um problema. No primeiro caso, um conceito que representa dados de entrada possivelmente pode representar alguma informação que é utilizada pelo conector para produzir uma saída. Esse conceito também pode representar uma informação que, de fato, não é utilizada no processo de integração. No segundo caso, um conceito que representa os dados de saída pode representar uma informação que possa ser derivada dos dados de entrada. Contudo, caso não seja possível obter qualquer associação ou equivalência entre os dados de entrada e saída do conector não podemos afirmar que integração semântica foi obtida. 
Finalmente, podemos considerar a realização de uma revisão da ontologia de referência de modo a incluir novos conceitos e/ou relacionamentos ou revisar conceitos e relacionamentos existentes na versão atual da ontologia.

\section{Adequação dos dados de interesse}

Após o mapeamento para ontologia de referência devemos identificar a necessidade de conversão sintática e semântica nos dados de interesse de modo a eliminar potenciais incompatibilidades. Para identificar eventuais necessidades de conversão sintática nos dados devemos verificar o formato e a sintaxe de representação de cada conceito de entrada/saída do conector mapeado com sucesso para a ontologia de referência. Um exemplo de conversão sintática é a conversão de formatos de arquivo. Existem situações em que os dados de entrada do conector estão em um arquivo cujo formato não condiz com o formato aceito como saída do conector. Neste caso, torna-se necessária a conversão de formato de arquivo de modo que os dados sejam convertidos em outro formato, modificando a forma em que estão representados, sem sofrer alterações de conteúdo. Caso seja necessária conversão devemos especificar como esta operação de adequação sintática será realizada.

Nesta atividade também devemos identificar a necessidade de realizar adequações semânticas nos dados de interesse de modo a eliminar possíveis incompatibilidades. Para realizar essa identificação devemos realizar uma análise de cada conceito de saída do conector mapeado inicialmente sem sucesso para um conceito de entrada equivalente. Para tornar possível a conversão devemos verificar a possibilidade de obter o conceito de saída a partir do conjunto de dados de entrada ou a partir de outra fonte de dados. Caso seja possível realizar essa operação de adequação semântica, devemos especificar como esta operação de adequação semântica será realizada. Essas adequações devem ser especificadas para cada conector. No caso de um conector composto, as adequações sintáticas e semânticas devem ser especificadas para cada conector simples que o compõem.

\section{Identificação de políticas de acesso e ativação}

Após identificar a necessidade de adequações dos dados de interesse devemos definir as políticas de acesso e ativação do objeto alvo da integração (ferramenta ou fonte de dados). A descrição da política de acesso deve identificar qual a forma de acesso às funcionalidades (local ou remota) desse objeto. Além disso, devemos coletar informações sobre o local de 
instalação lógica do objeto alvo e eventuais restrições de acesso (público ou acesso privado com autorização). Essa descrição representa um requisito relevante para a implementação do conector.

A descrição da política de ativação do objeto alvo também representa um requisito relevante. Nessa descrição deve ser definida a forma com que haverá a transferência de controle (passagem da thread de execução) para o objeto alvo da integração (manual ou automática). A ativação automática só é possível caso haja uma API (interface de programação de aplicações) descrevendo como as funcionalidades do objeto alvo podem ser invocadas. Caso contrário, somente a ativação manual será possível.

As definições das políticas de acesso e ativação devem ser realizadas por meio de uma descrição textual. As informações contidas nessas definições podem ser derivadas de informações descritas no cenário de integração, manuais e páginas de ajuda e documentação da API, se disponível.

\section{Implementação do conector}

Após a identificação das políticas de acesso e ativação devemos realizar a implementação do conector. O objetivo dessa atividade é sistematizar o processo de implementação de modo a facilitar a execução desse processo por parte do desenvolvedor. Esta abordagem não prescreve a linguagem de programação a ser utilizada. Tanto linguagens orientadas a objeto quanto linguagens procedurais podem ser utilizadas. A linguagem mais adequada depende dos recursos oferecidos para implementar a transferência de controle.

As funcionalidades de cada conector a ser implementado estão divididas em quatro blocos funcionais: 1) processamento de entrada; 2) processamento de adequações sintáticas; 3) processamento de adequações semânticas; e 4) processamento de saída e transferência de controle. O primeiro bloco envolve o processamento inicial dos dados de entrada de modo que os mesmos estejam disponíveis para serem utilizados pelo conector. O segundo bloco envolve procedimentos para realizar adequações sintáticas nos dados de entrada. O terceiro bloco envolve procedimentos para realizar adequações semânticas nos dados de entrada. O segundo e o terceiro bloco só são implementados caso haja necessidade de conversões sintática e semântica nos dados. O último bloco envolve processamento dos dados de saída do conector e procedimentos para acesso do objeto alvo da integração e transferência de controle para o mesmo baseados nas políticas de acesso e ativação. Esses procedimentos só 
serão implementados caso o conector seja responsável por realizar o acesso e a ativação de um objeto alvo e, além disso, a ativação automática do mesmo seja possível.

Os requisitos para a implementação de cada bloco funcional podem ser identificados a partir da descrição detalhada dos dados de interesse, informações sobre a adequação sintática e semântica dos dados de interesse e identificação das políticas de acesso e ativação. Os blocos funcionais deverão ser executados nesta ordem. Para isso, deve existir uma thread de controle no conector.

O conector pode ser implementado isoladamente da ferramenta origem da integração $\mathrm{T}_{\mathrm{A}}$ ou de forma integrada. A implementação isolada torna a integração dependente do usuário, uma vez que o mesmo deve ativar manualmente o conector. A implementação de forma integrada torna o processo automático, contudo o desenvolvedor do conector deve ter acesso ao código fonte de $\mathrm{T}_{\mathrm{A}}$ para que possa realizar, a partir da ferramenta, uma transferência de controle para o conector. Cabe ao desenvolvedor identificar a melhor forma de implementar. Finalizada a implementação devemos testar o conector considerando-se o cenário de integração especificado.

\subsection{Ontologia de Referência}

Diferentes ontologias estão disponíveis e são utilizadas na área de bioinformática. Contudo essas ontologias focam aspectos específicos dessa área, como, por exemplo, conceitos relacionados a processos biológicos, componentes celulares, funções moleculares, sequências moleculares, etc. Não há uma ontologia com foco específico no domínio de análise de expressão gênica, embora conceitos relacionados a esse domínio estejam presentes em diversas ontologias. Neste sentido, uma ontologia de referência foi definida especificamente para esse domínio com foco na representação de informações contida nos dados utilizados por ferramentas de análise de expressão gênica. Essa ontologia utiliza alguns conceitos presentes nas ontologias Gene Ontology (GO) [64] e Sequence Ontology (SO) [66], bem como apresenta conceitos e relacionamentos próprios. Uma característica dessa e de outras ontologias é que a mesma deve ser adaptável, isto é, novos conceitos e relacionamentos podem ser incluídos e/ou alterados de acordo com a evolução do conhecimento da área e de outras necessidades específicas.

O desenvolvimento da ontologia de referência foi motivado pela falta de uma ontologia específica do domínio para ser utilizada como suporte à integração de ferramentas 
de análise de expressão gênica. Essa ontologia compartilha informações do domínio de análise de expressão gênica de modo que novas ferramentas possam utilizar essas informações para detectar inconsistências e erros conceituais durante a integração. Desse modo o processo de integração de ferramentas utilizando a ontologia de referência como suporte pode gerar resultados mais confiáveis.

A representação da ontologia de referência utiliza diagramas de classes UML. Essa linguagem foi escolhida por ser bastante conhecida e por permitir uma representação em alto nível de abstração dos conceitos e relacionamentos existentes no domínio. Essa representação é suficiente para suprir as necessidades decorrentes da aplicação da abordagem proposta, uma vez que as informações contidas nessa ontologia são utilizadas apenas como referência para prover suporte à integração de ferramentas de análise de expressão gênica (nenhum processamento automático ou inferência é realizado).

A Figura 12 apresenta um conjunto de conceitos relacionados a ácidos nucleicos. Um conceito é representado por retângulo rotulado. Uma linha sólida interconectando dois conceitos ou um conceito a ele mesmo representa uma associação. Um diamante preenchido ao final de uma associação representa uma associação de composição. Uma linha com um triângulo não preenchido ao final representa uma generalização. Os conceitos com preenchimento cinza representam elementos utilizados de outras ontologias.

Um ácido nucleico (Nucleic_Acid) representa um composto químico formado por uma sequência de nucleotídeos (Nucleotide), os quais representam as unidades básicas desse composto. Existem dois tipos de ácidos nucleicos: DNA (ácido desoxirribonucleico) e RNA (ácido ribonucleico). O DNA representa uma molécula que armazena informações genéticas e pode conter genes (Gene). Esses genes são representados por uma ou mais sequências de bases ordenadas (Base_sequence).

O DNA realiza os processos de replicação (is_replicated_into) e de transcrição (is_transcribed_into). O processo de replicação consiste na duplicação semiconservativa da molécula de DNA que gera outra molécula. O processo de transcrição consiste na síntese de RNA utilizando o DNA como molde. Esses processos estão representados por relações de associação que possuem multiplicidade agregada. A multiplicidade expressa numericamente (valor exato, intervalo ou vários) a quantidade de instâncias de cada conceito que pode ocorrer na relação. Assim, na replicação um DNA pode gerar um ou vários DNAs, enquanto que na transcrição um DNA pode gerar um ou vários RNAs. 
O RNA representa uma estrutura intermediária responsável pela síntese de proteínas da célula. Existem diferente tipos de RNA. No contexto deste trabalho os tipos de RNA mais relevantes incluem RNA mensageiro ( $m R N A)$, RNA ribossômico ( $r R N A)$, RNA transportador $(t R N A)$ e RNA não-codificante (ncRNA).

O RNA mensageiro ( $m R N A)$ é o responsável pelo envio de informações do núcleo da célula para o meio em que a proteína será sintetizada. O RNA ribossômico $(r R N A)$ é o componente primário para a formação dos ribossomos. O RNA transportador (tRNA) é responsável pelo transporte de moléculas de aminoácidos até os ribossomos para formação de proteína. Por último, o RNA não-codificante ( $n c R N A)$ representa um RNA que não é traduzido e nem participa do processo de síntese de proteína.

RNA é um tipo de produto gênico funcional (Functional_Gene_Product). O produto gênico funcional representa o produto gerado como resultado do processamento das informações genéticas contida em um gene. Proteína (Protein) representa um composto orgânico que, assim como o $R N A$, também é um tipo de produto gênico funcional.

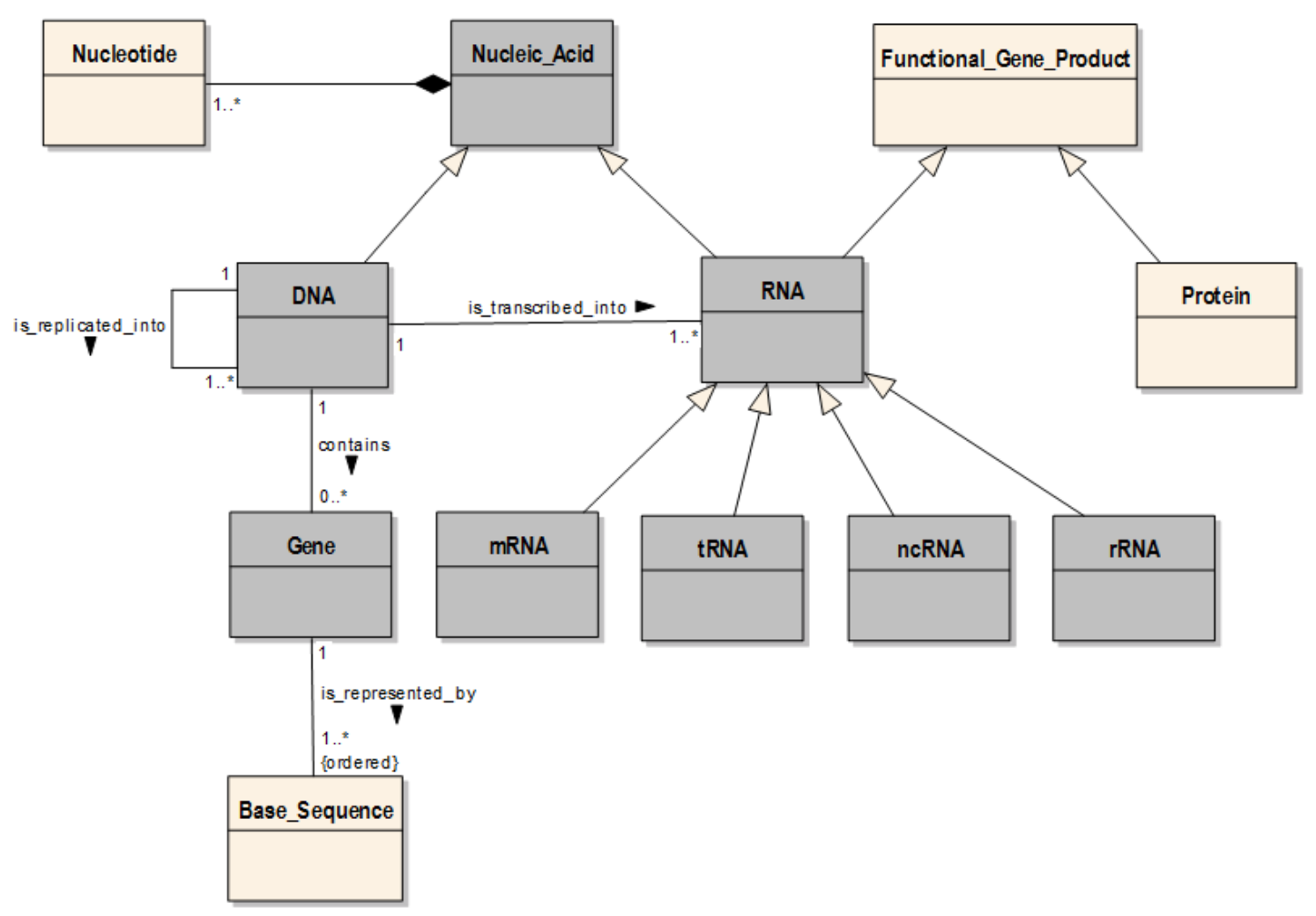

Figura 12: Conceitos e relacionamentos associados a ácidos nucleicos 
A Figura 13 ilustra conceitos relacionados à expressão gênica de um produto funcional. O produto gênico funcional (Functional_Gene_Product) representa a entidade responsável pela ocorrência do processo de expressão gênica (Gene_Expression). Esse processo representa um fenômeno biológico que envolve desde a decodificação da informação contida em um gene até a formação de um produto funcional. Expressão gênica é representada por valores que quantificam o nível que um produto funcional é expresso através de uma medição relativa (Gene_Expression_Value). Esses valores podem ser classificados em valores baseados em RNAs (RNA_Based_Value) ou proteínas (Protein_Based_Value). Tal classificação foi definida com base nas técnicas utilizadas para obter os dados de expressão gênica. Uma condição experimental (Experimental_Condition) representa uma condição sobre a qual experimentos com genes são submetidos para realizar a medição da expressão gênica. A condição experimental (Experimental_Condition) afeta a expressão gênica (Gene_ Expression) e consequentemente torna os valores de expressão gênica (Gene_Expression_ Value) dependentes dessa condição.

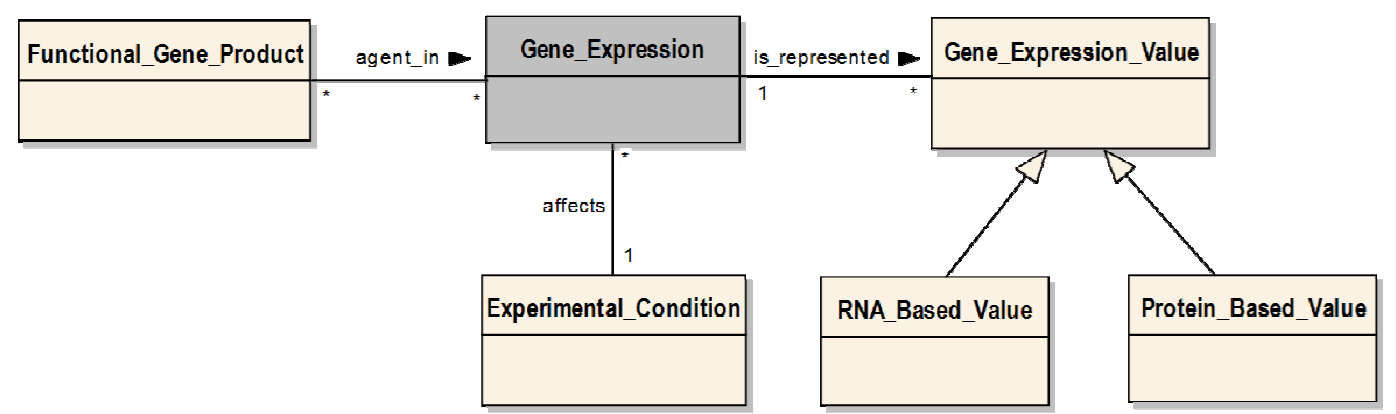

Figura 13: Conceitos e relacionamentos associados à Expressão Gênica

A Figura 14 ilustra conceitos relacionados às abordagens para obtenção de dados de expressão gênica. Gene_Expression_Analysis_Approach representa os diferentes tipos de abordagens disponíveis para a obtenção de dados de expressão gênica baseadas em RNA. Três tipos de abordagens foram identificados: abordagens baseadas em sequências (Sequence_Based_Approach), abordagens baseadas em hibridização (Hybridization_Based_ Approach) e demais abordagens (Other_Approach). Sequence_Based_Approach representa abordagens que utilizam o sequenciamento de genes como método para obtenção de dados de expressão gênica. cDNA_Sequencing, RNA-Seq e SAGE (Tag_Based_Approach) são os tipos mais conhecidos dessa abordagem. 
Hybridization_Based_Approach representa abordagens que realizam a hibridização de elementos como método para obtenção de dados. Abordagens one-color (Onecolor_Microarray) e two-color (Two-color_Microarray) são tipos de Hybridization_Based_Approach. Microarray de oligonucleotídeo one-color (Onecolor_Oligonucleotide) é um tipo de One-color_Microarray. Microarray de Tiling (Tiling_Microarray) é um tipo de One-color_Oligonucleotide. Microarray de impressão (Spotted_Microarray), microarray amplificado (Amplified_Microarray) e microarray de oligonucleotídeo two-color (Two-color_Oligonucleotide) são tipos de Two-color_Microarray. Tilling_With_Reference_Microarray é um tipo de Two-color_Oligonucleotide. Demais abordagens (Other_Approach) representa abordagens que não se enquadram em nenhuma das anteriores. PCR em tempo real ( $q P C R)$ é um tipo de abordagem dessa categoria.

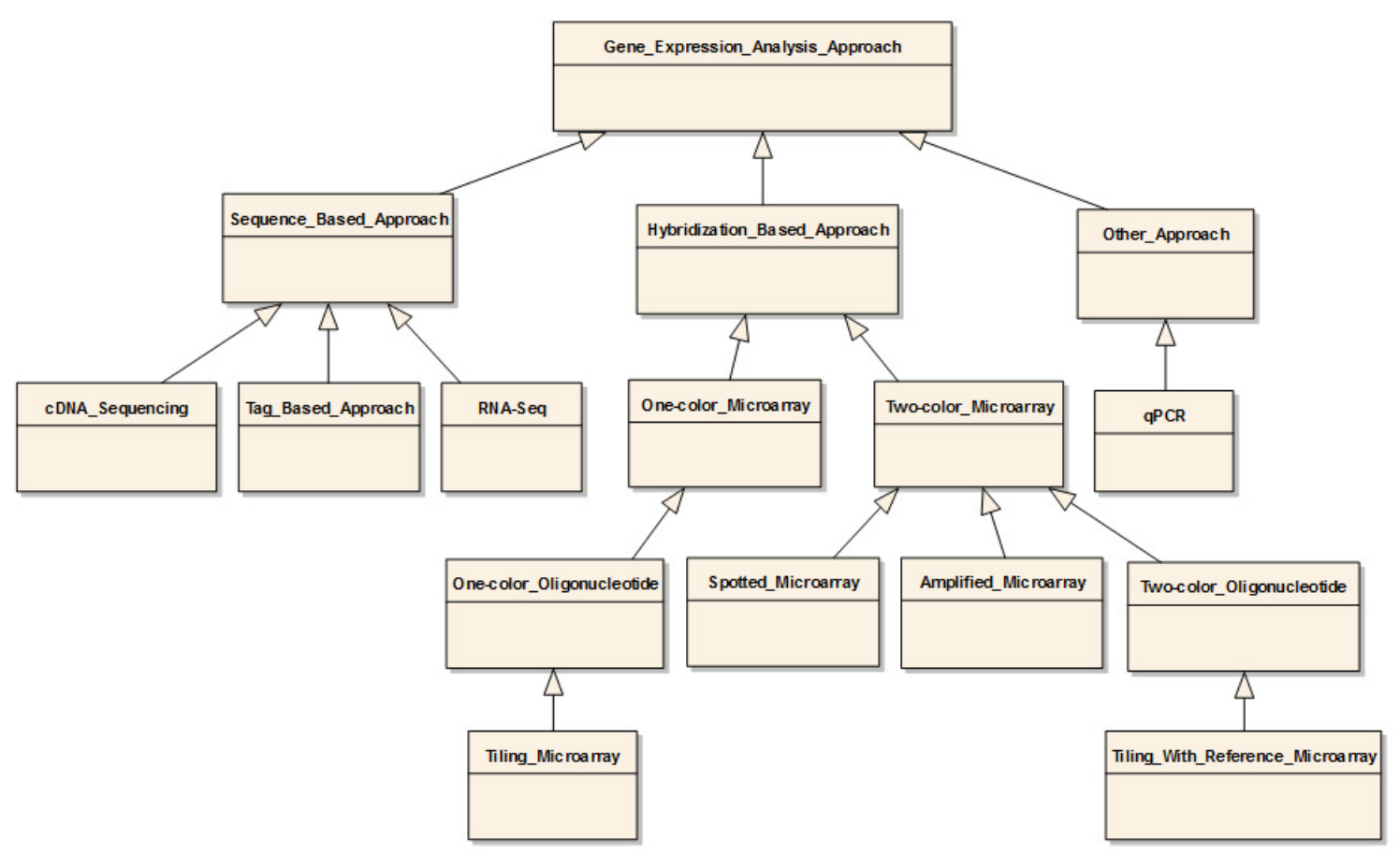

Figura 14: Abordagens para análise de expressão gênica

A Figura 15 apresenta os relacionamentos entre os diferentes tipos de abordagens para obtenção de dados de expressão gênica e os diferentes valores utilizados para a quantificação do nível de expressão gênica. No contexto deste trabalho não foram considerados valores obtidos a partir da expressão de proteínas. Os valores obtidos a partir da expressão de RNA são diferenciados pelo parâmetro utilizado na medição relativa da expressão gênica (razão, 
intensidade, contagem e amplificação). A abordagem Two-color_Microarray é quantificada através de valores baseados na razão (Ratio_Based_Value). A abordagem Onecolor_Microarray é quantificada através de valores baseados em intensidade (Intensity_Based_Value). A abordagem Sequence_Based_Approach é quantificada através de valores baseados em contagem (Count_Based_Value). A abordagem qPCR é quantificada através de valores baseados em amplificação (Amplification_Based_Value).

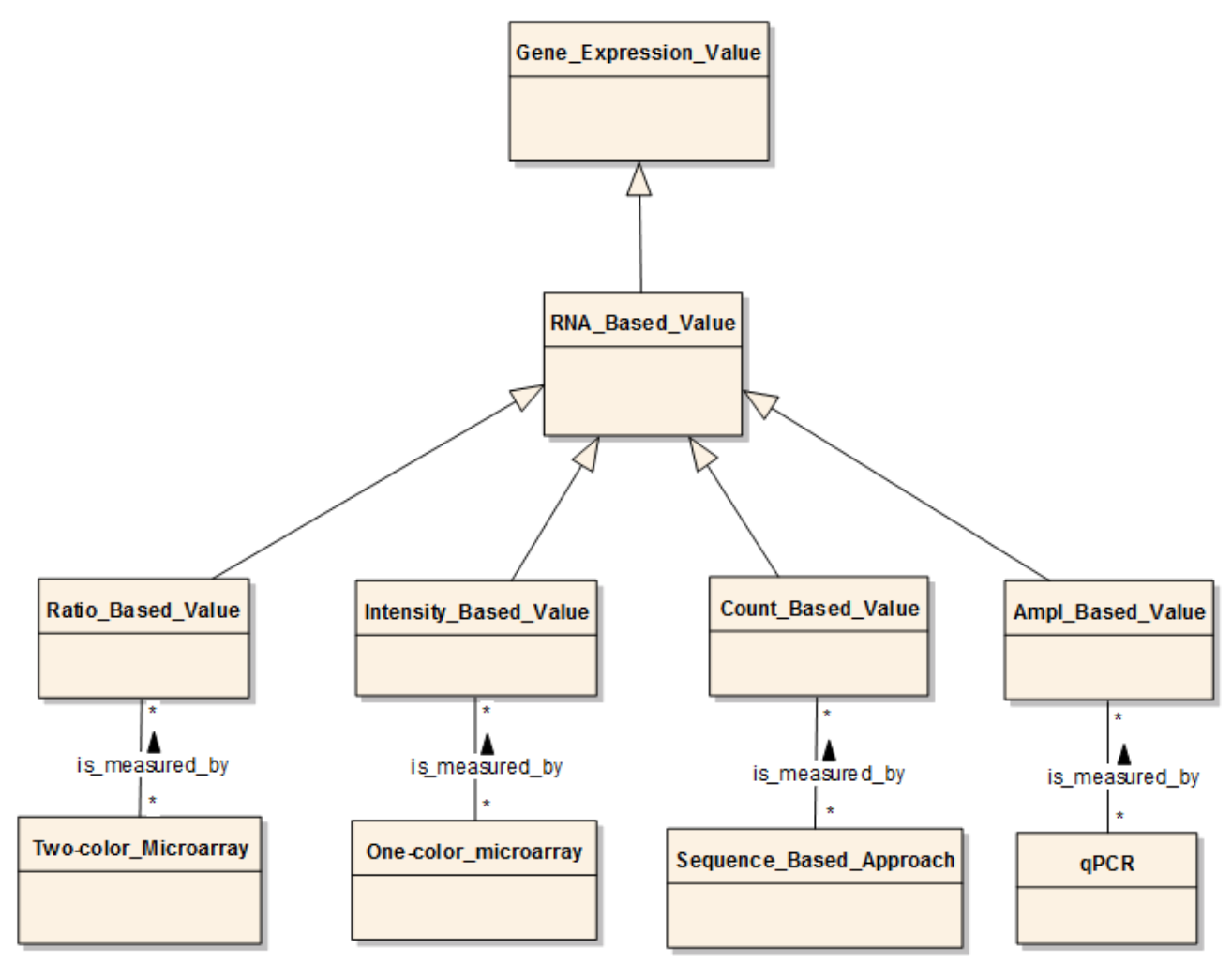

Figura 15: Conceitos e relacionamentos entre os tipos de dados de expressão gênica e valores associados

A Figura 16 apresenta um detalhamento da representação de valores de expressão gênica baseados em contagem. Count_Based_Value representa um valor obtido através da normalização (razão) entre a quantidade de vezes que um gene foi obtido de acordo com uma condição experimental (Sampled_Gene_Amount) dividido pelo número total de genes expressos (Total_Sampled_Gene_Amount) de acordo com a mesma condição. O conceito Total_Sampled_Gene_Amount é relevante apenas se a abordagem para obtenção de dados de expressão gênica é baseada em sequência (Sequence_Based_Approach). Sampled_Gene_ Amount foi modelado como uma classe de associação que representa o número de vezes que 
um gene (Gene) foi obtido de acordo com uma condição experimental (Experimental_ Condition).

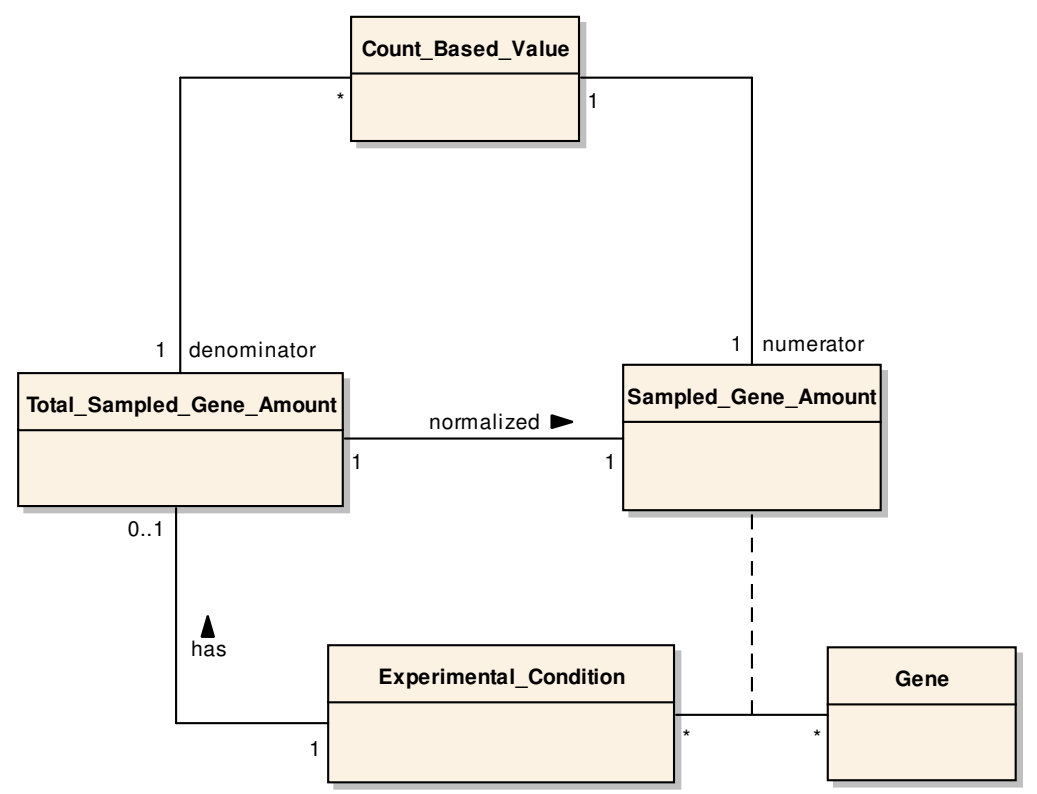

Figura 16: Conceitos e relacionamentos do valor baseado em contagem 


\section{ESTUDOS DE CASO}

Três estudos de caso envolvendo diferentes cenários de integração foram definidos para aplicar a abordagem proposta neste trabalho. O primeiro estudo de caso foi fundamentado em um cenário idealizado pelos desenvolvedores do Gaggle [93] para explorar e analisar a patogenicidade da bactéria Helicobacter pylori utilizando diferentes ferramentas. Em particular, foram utilizadas as ferramentas DMV, RGui e TMeV com o objetivo de realizar a clusterização dos dados de entrada obtidos utilizando a técnica de microarray de DNA. Primeiramente, os dados de microarray passam pelo processo de filtragem de dados utilizando a ferramenta DMV. A filtragem é feita com base em um critério pré-estabelecido. Os dados de saída gerados pelo DMV servem como entrada para a ferramenta RGui. Essa ferramenta, baseada na linguagem R [30], pode ser utilizada para realizar diversas análises estatísticas. Neste caso, esta ferramenta é utilizada para realizar a normalização dos dados. Os dados normalizados são utilizados como entrada para a ferramenta $\mathrm{TMeV}$, que realiza o serviço de clusterização dos dados de microarray.

A Figura 17 ilustra a arquitetura de integração destas ferramentas. Dois conectores são utilizados nesta integração: $C_{1}$, para integrar as ferramentas DMV e RGui, e $C_{2}$, para integrar as ferramentas RGui e TMeV. Esses conectores realizam o processamento e verificação dos dados com a finalidade de garantir que os dados de saída de uma ferramenta sejam consistentes e sirvam como entrada para a ferramenta seguinte. O Apêndice A apresenta os principais aspectos do desenvolvimento do conector $\mathrm{C}_{1}$, enquanto que o Apêndice B apresenta os principais aspectos do desenvolvimento do conector $C_{2}$. 


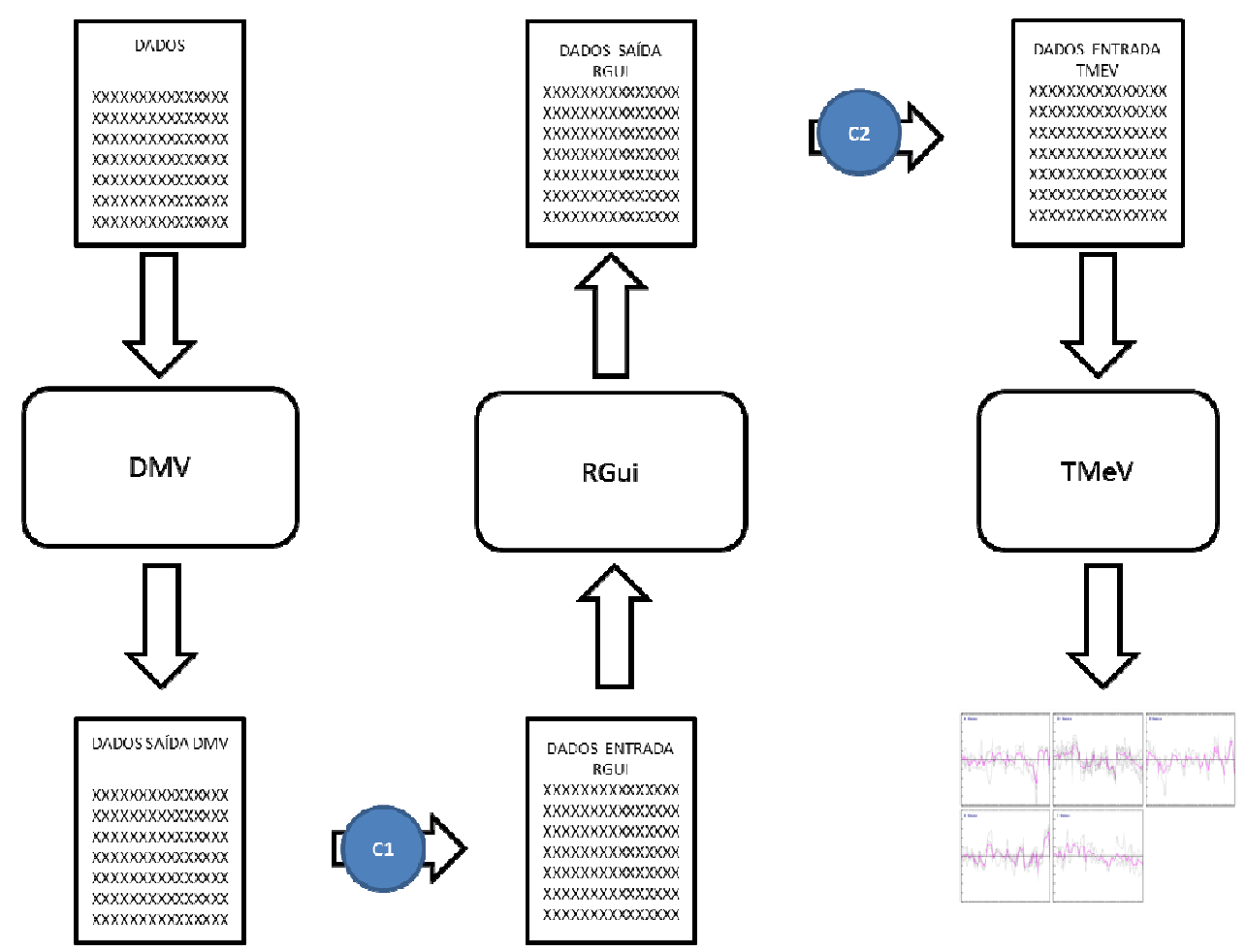

Figura 17: Arquitetura de integração das ferramentas DMV, RGui e TMeV

Apesar do desenvolvimento dos conectores deste estudo de caso utilizar uma abordagem semântica, diferencial da abordagem utilizada pelo Gaggle, constatou-se que a integração das ferramentas envolvidas nesse estudo de caso foi bem simples. Pouco ou nenhum processamento dos dados foi necessário na integração. No geral foi necessário apenas verificar a consistência destes dados sem a necessidade de transformações, uma vez que os dados gerados como saídas de uma ferramenta são dados aceitos como entrada para as ferramentas subsequentes.

Com o intuito de aprimorar a abordagem proposta através de situações mais elaboradas envolvendo eventuais transformações nos dados, foram definidos dois outros estudos de caso. O segundo estudo de caso consiste na integração das ferramentas DMV e $\mathrm{TMeV}$, descritas no primeiro estudo de caso, com o mesmo objetivo de realizar a clusterização dos dados de entrada inicial. Contudo, nesse caso, os dados iniciais utilizados no segundo estudo, resultado da execução de uma abordagem baseada em sequenciamento (RNA-Seq, sequenciamento de cDNA), necessitam que um pré-processamento seja realizado para que possam ser utilizados pelas ferramentas, DMV e TMeV (veja Figura 18). Esse estudo foi baseado em um cenário utilizado por um grupo de pesquisadores do Instituto de 
Matemática e Estatística da Universidade de São Paulo que realizou a estimação usual da abundância dos genes, de modo a agregar diferentes sequências de bases nitrogenadas a um mesmo gene e então realizar a contagem do número de vezes que cada gene foi obtido de acordo com uma dada condição experimental [94].

Inicialmente são utilizados dados de expressão gênica obtidos a partir de uma técnica de sequenciamento de DNA como entrada para este estudo de caso. Essa técnica gera como resultado arquivos de texto com dados estruturados em uma lista de String (cadeia de caracteres). Cada String consiste em uma sequência de bases nitrogenadas (A, C, T, G). Essas sequências possuem tamanho fixo e limitado e podem aparecer diversas vezes no mesmo arquivo. Além disso, as sequências podem ou não ser representativas de algum gene conhecido.

Os arquivos contendo os dados de expressão gênica são processados de modo a produzir arquivos contendo dados de entrada para a ferramenta DMV. Esse processamento é dividido em duas etapas. A primeira etapa consiste na busca e identificação de genes contidos em um repositório de dados BLAST e posterior substituição das sequências gênicas por seus respectivos identificadores, caso o identificador exista. Dessa forma são gerados arquivos que contenham a mesma lista de dados de entrada com a diferença que os valores das sequências de bases que estão associadas a algum gene identificado no BLAST são substituídos por seus respectivos identificadores dos genes.

A segunda etapa consiste no processamento desses dados modificados para que esses dados possam ser filtrados, por algum critério estabelecido, utilizando a ferramenta DMV. Contudo, essa ferramenta necessita de dados numéricos como entrada, o que não condiz com os arquivos gerados na primeira etapa. Desse modo é necessário realizar um processamento dos dados para que os mesmos possam ser convertidos em dados aceitos pela ferramenta DMV. Essa etapa de processamento gera como resultados duas matrizes de dados, uma das quais é utilizada como entrada requerida pela ferramenta DMV.

A primeira matriz consiste no registro da frequência com que cada sequência ou gene aparece em cada arquivo de entrada. Cada linha consiste de uma sequência ou um identificador do gene e cada coluna consiste de um arquivo. Portanto, os valores da matriz consistem na quantidade de vezes que a sequência determinada pela linha apareceu no arquivo na coluna correspondente. Essa matriz é armazenada em um novo arquivo. A segunda matriz consiste no registro do número total de sequências existentes em cada arquivo. Essa matriz 
consiste de múltiplas colunas que representam um arquivo e uma única linha de dados com o registro das quantidades de sequências existentes no arquivo correspondente àquela coluna. Posteriormente, a ferramenta DMV é utilizada para filtrar os dados do primeiro arquivo através de um determinado critério. Dessa forma essa ferramenta gera como saída um subconjunto filtrado dos dados do primeiro arquivo que condiz com um dado critério estabelecido. Contudo, esses dados ainda não servem como entrada para ferramenta $\mathrm{TMeV}$, dado que esta necessita de matrizes com valores reais.

Os dados produzidos pela ferramenta DMV devem ser normalizados para que possam ser utilizados como entrada pela ferramenta $\mathrm{TMeV}$. Essa normalização deve considerar a frequência com que cada sequência (linha da matriz) aparece no arquivo (coluna da matriz). Dessa forma, a entrada da ferramenta TMeV consiste de um arquivo contendo dados obtidos através da divisão do número de vezes que a sequência aparece em cada arquivo (saída do DMV) pelo número total de sequências existentes no arquivo (obtido na segunda matriz). Esse arquivo contendo os dados normalizados é utilizado como entrada para a ferramenta $\mathrm{TMeV}$ para realizar a clusterização dos dados, produzindo como resultado um gráfico pronto para análise.

A Figura 18 ilustra a arquitetura de integração de ferramentas no segundo estudo de caso. Dois conectores são utilizados nesta integração: $\mathrm{C}_{1}$, para transformar dados de expressão gênica produzidos através da técnica de sequenciamento de DNA em dados que possam ser utilizados pela ferramenta DMV, e $\mathrm{C}_{2}$, para normalizar os dados produzidos pela ferramenta DMV para que possam ser utilizados como entrada pela ferramenta $\mathrm{TMeV}$. 


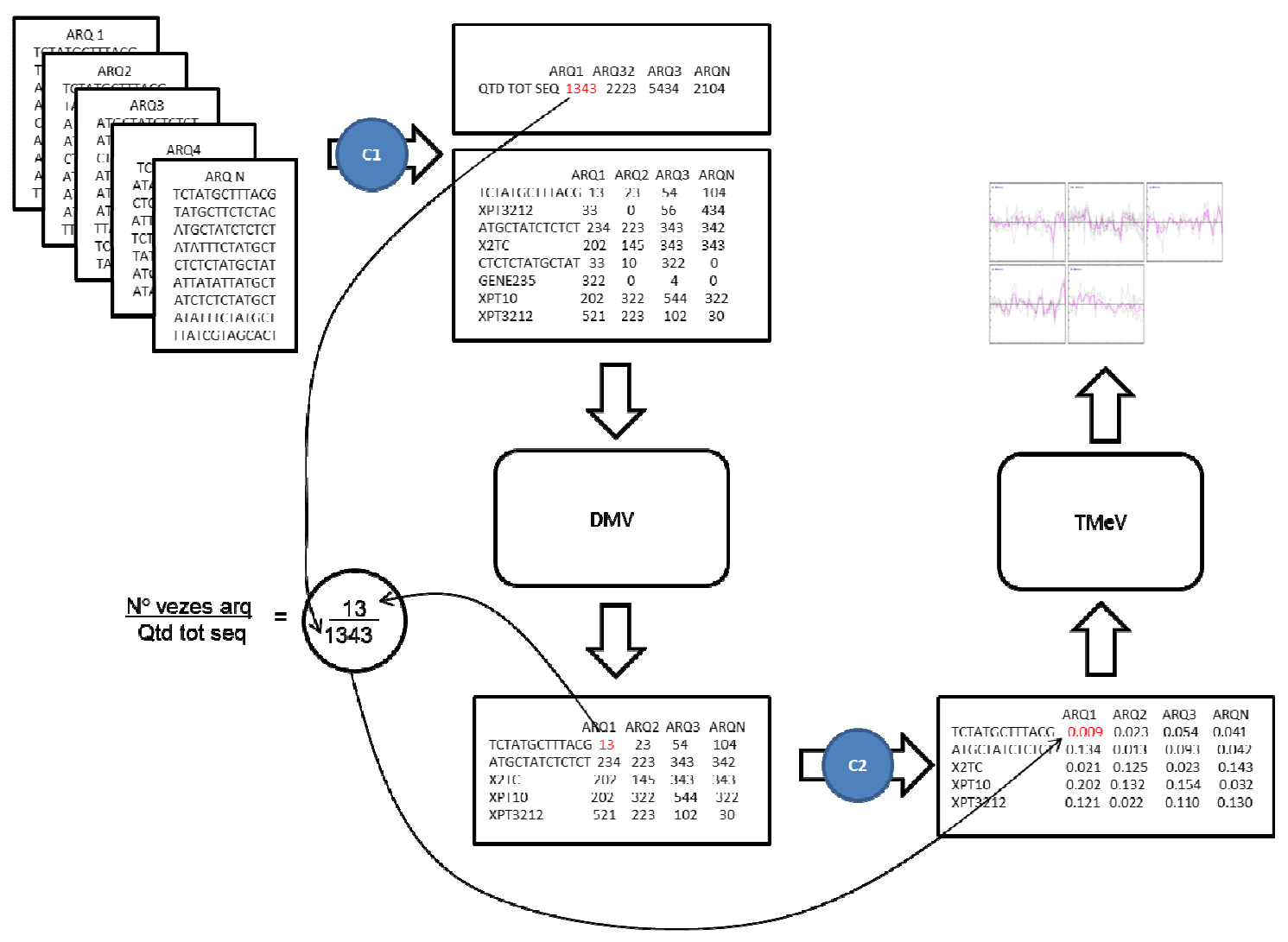

Figura 18: Arquitetura de integração de dados BLAST a ferramentas DMV e TMeV

O terceiro estudo de caso consiste em transformar dados de microarray provenientes da abordagem one-color em dados da abordagem two-color para posterior processamento. Essa transformação pode ser feita a partir da divisão de valores obtidos por duas abordagens one-color de modo a obter uma razão de valores, similar à gerada pela abordagem two-color $[95,96]$. Os dados transformados são utilizados pela ferramenta RGui em um teste de hipótese de modo a selecionar um conjunto de genes de interesse. Os genes selecionados servem então como entrada para a ferramenta DAVID [97], a qual é utilizada na classificação de genes e posterior associação desses a doenças.

Inicialmente são selecionados dados de humanos separados por categorias, tais como doentes e sadios. Cada arquivo possui dados referentes a um indivíduo e estão representados em uma matriz de valores numéricos em que cada linha consiste de um gene e cada coluna um valor de expressão gênica utilizando a abordagem one-color. Para que esses dados possam ser utilizados pela ferramenta RGui para realizar um teste de hipótese, era necessário que os valores de entrada fossem valores provenientes de abordagem two-color. 
Podemos obter valores two-color simulados através do cálculo da razão entre dois valores obtidos pela abordagem one-color $[95,96]$. Para obter essa razão, os valores obtidos pela abordagem one-color devem ser cruzados entre as categorias, ou seja, os dados de cada humano sadio são cruzados com os dados de cada humano doente. As razões são então armazenadas em uma matriz em um novo arquivo. Essa matriz representa em cada linha um gene e em cada coluna a razão entre os valores de expressão do gene em um indivíduo de uma categoria com um indivíduo de outra categoria. O número de colunas deve corresponder ao número de combinações possíveis para que todos os representantes de uma categoria sejam cruzados com todos os representantes das demais categorias.

Um segundo arquivo também deve ser gerado com os dados em uma matriz. Contudo, para compor essa matriz os valores das razões são obtidos através do cruzamento de indivíduos da mesma categoria. Assim a razão é obtida pelo cruzamento de um indivíduo sadio com outro da mesma categoria. Os dois arquivos gerados são utilizados como entrada para a ferramenta RGui para realizar uma análise estatística desses dados.

A ferramenta RGui é utilizada na realização de um teste de hipótese, também conhecido como teste $\mathrm{t}$ [98]. Esse teste pode gerar como resultado uma matriz na qual cada linha consiste de um gene associado a duas colunas, uma com valores numéricos resultantes do teste e outra com valores numéricos de $p$-value. Esses dados são filtrados usando um dado limiar informado pelo usuário, de modo a selecionar somente os identificadores dos genes cujos valores resultantes do teste $\mathrm{t}$ e $p$-value sejam menores que os valores de limiar escolhido. Caso o usuário não defina um valor de limiar, um valor padrão é atribuído para $p$ value de 0,01 e o valor do teste t não é considerado na filtragem. Após a filtragem, temos uma lista de genes que serve como entrada para a ferramenta DAVID. Essa ferramenta aceita como entrada uma lista de genes e, através da análise dos genes listados, gera como saída diferentes informações relacionadas, tais como agrupamentos clusterizados de genes relacionados, lista de associação de genes a doenças, lista de genes relacionados que não estão na lista de entrada, redirecionamento para literaturas relacionadas, etc.

A Figura 19 ilustra a arquitetura de integração de ferramentas no terceiro estudo de caso. Dois conectores são utilizados nesta integração: $\mathrm{C}_{1}$, para simular dados de microarray two-color a partir de dados de microarray one-color de modo a permitir que os mesmos sejam utilizados pela ferramenta $\mathrm{RGui}$, e $\mathrm{C}_{2}$, para realizar o serviço de filtragem dos dados de modo 
a permitir que o resultado gerado pela ferramenta RGui seja utilizado como entrada para ferramenta DAVID.

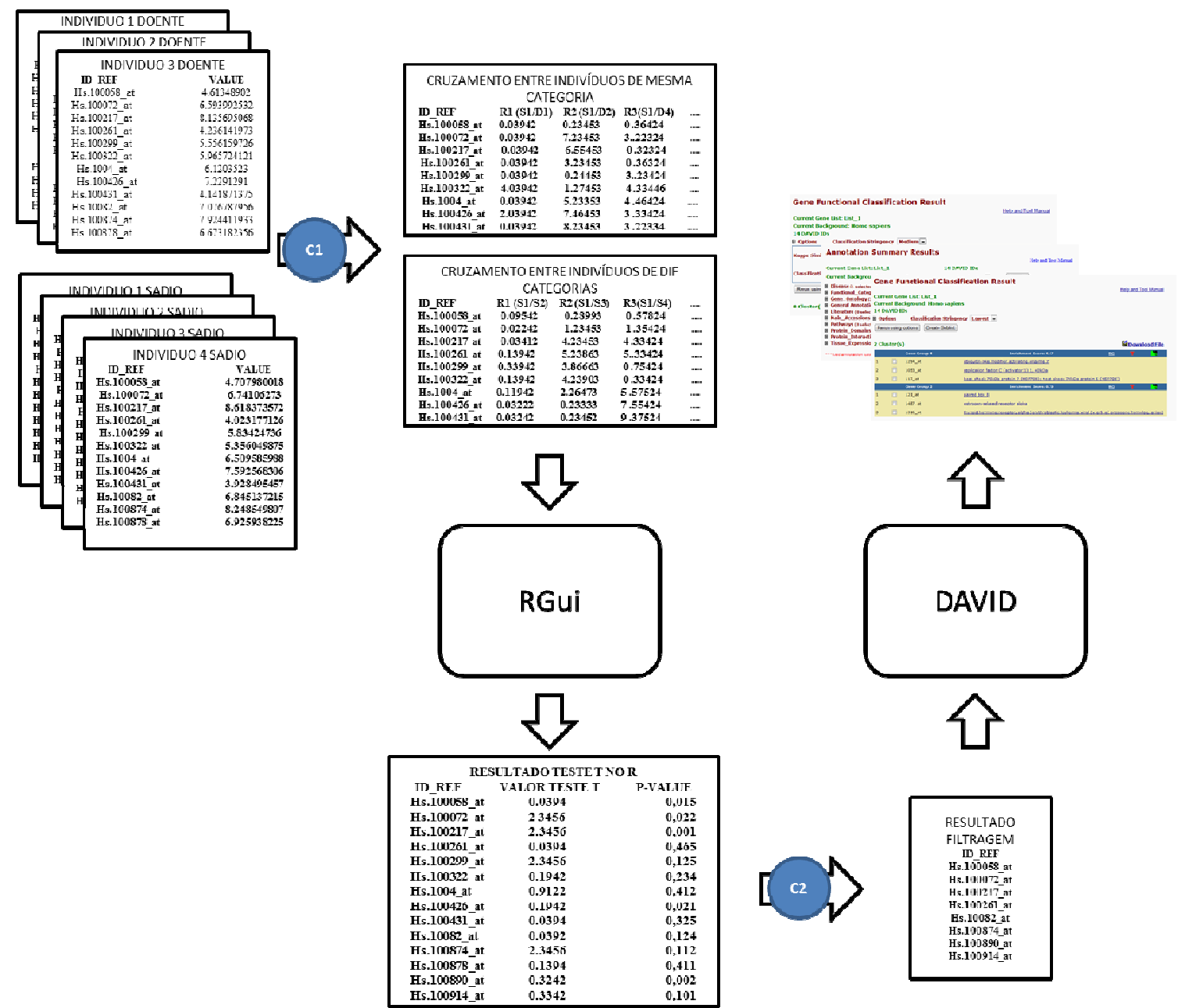

Figura 19: Arquitetura de integração de dados de microarray one-color a ferramentas RGui e DAVID 


\section{CONCLUSÃO}

\subsection{Discussão}

Diferentes problemas surgem quando da integração de um conjunto de dados e/ou ferramentas para a construção de um ambiente adequado (pipeline de ferramentas) para a análise de expressão gênica, tais como a necessidade de interoperabilidade sintática e, principalmente, a necessidade de interoperabilidade semântica dos dados envolvidos na integração. Embora existam diferentes abordagens e plataformas de suporte para a integração semântica de ferramentas e bases de dados no domínio de bioinformática, essas, em geral, são limitadas à realização de consultas integradas a múltiplas fontes de dados. Neste sentido, existe uma carência de abordagens suficientemente abrangentes para tratar uma vasta gama de problemas e, ao mesmo tempo, específicas para a integração de ferramentas de análise de expressão gênica.

A abordagem proposta neste trabalho faz uso de diretrizes e de uma ontologia de referência para prover suporte ao processo de integração de ferramentas de análise de expressão gênica. As diretrizes consistem de um conjunto de atividades que devem ser executadas com o objetivo de desenvolver um conector responsável pela integração de ferramentas e/ou bases de dados utilizadas no processo de análise de expressão gênica. Por sua vez, a ontologia de referência é utilizada como um artefato de apoio visando garantir a interoperabilidade semântica durante o desenvolvimento do conector. Dessa forma, o foco principal da abordagem é prover suporte ao desenvolvimento de um conector de modo a garantir a interoperabilidade semântica dos dados envolvidos no processo de integração.

Existem diferentes abordagens encontradas na literatura para a integração de ferramentas ou bases de dados em bioinformática. Algumas destas propostas provêem suporte à interoperabilidade sintática, e.g., Gaggle [93], enquanto que outras focam também a interoperabilidade semântica, e g., TAMBIS [77] e ONTOFUSION [78]. O propósito geral do Gaggle é prover a integração de ferramentas aplicando uma política de flexibilidade semântica dos dados, ou seja, o significado desses dados pode variar de acordo com o contexto de aplicação no qual estão inseridos. Assim, a aplicação dessa política possibilita transformar qualquer dado em uma das quatro estruturas de dados básicas definidas por esse ambiente, as quais, segundo o Gaggle, são suficientes para representar potencialmente qualquer dado utilizado na integração de ferramentas e bases de dados. Adaptadores 
associados às ferramentas integradas são desenvolvidos de forma manual e são então responsáveis pela conversão dos dados genéricos às estruturas específicas utilizadas pelas ferramentas.

Sistemas e plataformas tais como TAMBIS, SEMEDA [10], ONTOFUSION e ACGT [99] provêem suporte à interoperabilidade semântica através do uso de mediadores. Mediadores representam entidades de software capazes de relacionar (mapear) termos de um modelo ou ontologia global a um modelo (esquema) local ou específico. De maneira geral, tais sistemas são apenas usados para prover suporte à realização de consultas, i.e., recuperação de dados, em fontes de dados heterogêneas de forma integrada e transparente com base nos termos de uma ontologia global. Normalmente nenhum suporte é provido para a adição e/ou alteração das informações nas bases de dados. Adicionalmente, a integração de uma nova fonte de dados requer a adaptação, normalmente manual, de um mediador existente ou o desenvolvimento de um novo mediador, também de forma manual.

Ao compararmos a abordagem proposta neste trabalho para a integração semântica de ferramentas de análise de expressão gênica com outras abordagens, percebe-se que a mesma é mais abrangente e flexível e pode ser utilizada para a construção de cenários que vão muito além de meras consultas. Adicionalmente, as diretrizes propostas provêem suporte à identificação e definição de equivalências semânticas entre os dados produzidos e/ou consumidos pelas ferramentas em suas interações, garantindo assim a interoperabilidade entre as mesmas.

Por outro lado, uma das principais limitações deste trabalho consiste da falta de suporte (semi-) automático para a construção dos conectores, o que pode tornar o processo de desenvolvimento de um conector uma atividade não trivial para um biologista. Contudo, acreditamos que isto não é um problema dado que a abordagem proposta prescreve um conjunto de atividades que devem ser realizadas de forma sistemática para a construção de um conector, o que, além de facilitar o processo de desenvolvimento, minimiza eventuais falhas que o biologista poderia cometer caso optasse por um processo ad hoc de desenvolvimento. Adicionalmente, a abordagem proposta neste trabalho foi aplicada a cenários de integração não triviais onde dificilmente ferramentas ou ambientes de suporte (semi) automatizados obteriam sucesso.

Outra limitação deste trabalho foi o número restrito de ferramentas e bases de dados utilizadas nos estudos de caso. Considerando-se que existem diversas ferramentas e/ou bases 
de dados utilizadas no domínio de análise de expressão gênica para os mais variados propósitos, as quais podem ser combinadas de diferentes maneiras, o número de ferramentas utilizadas nos cenários de integração propostos foi restrito. Embora isto seja uma limitação, esta não inviabiliza a abordagem proposta uma vez que a mesma não está restrita apenas às ferramentas utilizadas. Esta abordagem foi definida de forma a ser mais abrangente possível, sem qualquer restrição a ferramenta ou base de dados utilizadas. Dessa forma, nossa abordagem pode ser aplicada na integração de outras ferramentas ou bases de dados, inclusive envolvendo outros domínios. Isto é possível graças à separação das diretrizes de desenvolvimento de um conector da ontologia de referência, possibilitando assim a aplicação destas diretrizes em outros domínios a partir do uso de ontologias de referências adequadas a estes domínios. Outro cuidado tomado neste trabalho foi a definição de estudos de caso suficientemente abrangentes de modo a envolver diferentes tipos de dados de expressão gênica. Tal cuidado permitiu avaliar a adequação da nossa proposta na identificação de potenciais problemas e suporte à solução dos mesmos através da adequação semântica dos dados quando necessário.

Neste sentido, as principais contribuições deste trabalho foram a definição de um conjunto diretrizes para suporte ao desenvolvimento de conectores e de uma ontologia de referência para o domínio de análise de expressão gênica. As diretrizes foram definidas independentemente da ontologia de referência, o que permite tanto a aplicação dessas diretrizes em outros domínios quanto a modificação (evolução) da ontologia de referência conforme necessário. Outra importante contribuição deste trabalho foi o projeto e a implementação dos conectores propriamente ditos. Embora os conectores tenham sido desenvolvidos tendo em vista um cenário específico, estes podem ser modificados com relativa facilidade de forma a integrar outras ferramentas com características similares às ferramentas utilizadas nos cenários propostos.

\subsection{Conclusão e Trabalhos Futuros}

Este trabalho propôs uma abordagem para a integração semântica de ferramentas de análise de expressão gênica utilizando conectores de software. A aplicação bem sucedida dessa abordagem em diferentes estudos de caso, representativos do domínio, comprovou sua utilidade e eficácia para auxiliar os biologistas a solucionar diferentes problemas e desafios frequentemente encontrados no processo de integração de ferramentas neste domínio. As 
diferentes integrações puderam ser realizadas de forma a evitar a ocorrência de erros, principalmente conceituais, e de modo a gerar resultados com significância biológica.

Diferentes trabalhos futuros poderão complementar os resultados obtidos neste trabalho. Um possível trabalho consiste em automatizar partes do processo de integração de ferramentas de análise de expressão gênica. A partir das diretrizes propostas podemos realizar um levantamento sobre quais atividades do processo de desenvolvimento de um conector podem ser automatizadas de modo a facilitar este processo para um biologista. Em princípio este processo deve ser semi-automatizado e supervisionado dado que podem existir situações em que a automatização completa não será possível ou desejável, devido à existência de variáveis dependentes de escolhas do usuário que podem comprometer a geração do resultado final.

Outro trabalho a ser realizado consiste do desenvolvimento de novos cenários de integração, os quais poderão ser desenvolvidos por outros usuários, tais biólogos e/ou bioinformatas a partir da utilização ou não da nossa abordagem (avaliação comparativa). Dentre os aspectos passíveis de avaliação, podemos citar o tempo de aprendizado das diretrizes, o tempo de desenvolvimento dos conectores e a eficácia da aplicação da abordagem através da verificação da consistência dos dados utilizados na integração e avaliação da confiabilidade dos resultados obtidos. 


\section{REFERÊNCIAS BIBLIOGRÁFICAS}

[1] Kumar, S., Dudley, J. Bioinformatics software for biologists in the genomics era. Bioinformatics, 23(14), pp. 1713-1717, 2007.

[2] Antonov, A.V., Schmidt, T., Wang, Y., Mewes, H.W. ProfCom: a web tool for profiling the complex functionality of gene groups identified from high-throughput data. Nucleic Acids Res. 36:W347-351, 2008.

[3] Berriz, G.F., Roth, F.P. The Synergizer service for translating gene, protein, and other biological identifiers. Bioinformatics, Aug. 2008 (Epub ahead of print).

[4] Lima-Mendez, G., Van Helden, J., Toussaint, A., Leplae, R. Prophinder: a computational tool for prophage prediction in prokaryotic genomes. Bioinformatics, 24(6):863-865, 2008.

[5] Oberto, J. BAGET: a web server for the effortless retrieval of prokaryotic gene context and sequence. Bioinformatics, 24(3):424-425, 2008.

[6] Barrera, J., Cesar, R.M. Jr, Ferreira, J.E., Gubitoso, M.D. An environment for knowledge discovery in biology. Comput Biol Med, 34(5), pp. 427-447, 2004.

[7] Duroux, P., Kaas, Q., Brochet, X., Lane, J., Ginestoux, C., Lefranc, M.P., Giudicelli, V. IMGT-Kaleidoscope, the formal IMGT-ONTOLOGY paradigm. Biochimie, 90 (4), pp. 570$583,2008$.

[8] Ramírez-Flandes, S., Ulloa, O. Bosque: Integrated phylogenetic analysis software. Bioinformatics, Sep 1, [Epub ahead of print], 2008.

[9] 20. Kilic, O., Dogac, A. Achieving clinical statement interoperability using R-MIM and archetype-based semantic transformations. IEEE Trans Inf Technol Biomed, 13(4), pp. 467 477, 2009.

[10] Köhler, J., Schulze-Kremer, S. The semantic metadatabase (SEMEDA): ontology based integration of federated molecular biological data sources. In silico biology, 2(3), pp. 219$231,2002$.

[11] Decker, S., Melnik, S., van Harmelen, F., Fensel, D., Klein, M., Broekstra, J., Erdmann, M., Horrocks, I. The Semantic Web: the roles of XML and RDF. IEEE Internet Computing, 2000 . 
[12] Watson, J.D., Myers, R.M., Caudy, A.A., Witkowski, J.A. DNA Recombinante: Genes e Genomas. $3^{\mathrm{a}}$ edição, Artmed Editora S.A. Porto Alegre, RS, 2009.

[13] Vencio, R.Z.N. Análise estatística na interpretação de imagens: microarranjos de DNA e ressonância magnética funcional. Tese (Doutorado) - Programa de Pós-Graduação em Bioinformática, Universidade de São Paulo. São Paulo: USP, 2006.

[14] Butte, A. The use and analysis of microarray data. Nature reviews. Drug discovery, 1(12), pp. 951-960, 2002.

[15] Rosen, K.M. , Lamperti E.D., Villa-Komaroff L. Optimizing the northern blot procedure. Biotechniques 1990 Apr;8(4):398-403.

[16] Rast, J.P., Amore, G., Calestani, C., Livi, C.B., Ransick, A., Davidson, E.H. Recovery of Developmentally Defined Gene Sets from High-Density cDNA Macroarrays. Division of Biology 156-29, California Institute of Technology, Pasadena, California, 91125.

[17] Rockett, J.C., Hellmann, G.M. Confirming microarray data - is it really necessary? Genomics 83:541, 2004.

[18] Bertone, P., Gerstein, M., Snyder M. Applications of DNA tiling arrays to experimental genome annotation and regulatory pathway discovery. Chromosome Res. 13: 259-274, 2005.

[19] Patterson, T.A., Lobenhofer, E.K., Fulmer-Smentek, S.B., Collins, P.J., Chu, T.M., et al. Performance comparison of one-color and two-color platforms within the MicroArray Quality Control (MAQC) project. Nat Biotechnol 24: 1140-1150, 2006.

[20] Alba, R., Fei, Z., Payton, P., Liu, Y., Moore, S.L., Debbie, P., Cohn, J., D'Ascenzo, M., Gordon, J.S., Rose, J.K., Martin, G., Tanksley, S.D., Bouzayen, M., Jahn, M. M., Giovannoni, J. ESTs, cDNA microarrays, and gene expression profiling: tools for dissecting plant physiology and development. Plant J. 2004 Sep;39(5):697-714.

[21] Velculescu, V.E., Zhang, L., Vogelstein, B., Kinzler, K.W. Serial analysis of gene expression. Science 270, pp. 484-487, 1995.

[22] Reinartz, J., Bruyns, E., Lin, J.Z., Burcham, T., Brenner, S., Bowen, B., Kramer, M., Woychik, R. Massively parallel signature sequencing (MPSS) as a tool for in-depth quantitative gene expression profiling in all organisms. Brief Funct Genomic Proteomic. 2002 Feb;1(1):95-104.

[23] Wang, Z., Gerstein, M., Snyder, M. RNA-Seq: a revolutionary tool for transcriptomics. Nature Reviews Genetics 10, 57-63 (January 2009). 
[24] Heid, C.A., Stevens, J., Livak, K.J., Williams, P.M. Real Time Quantitative PCR Publicado por Cold Spring Harbor Laboratory Press. Disponível em <http://genome. cshlp.org>. Acesso em 16/09/2010.

[25] Anderle, P., Duval, M., Draghici, S., Kuklin, A., Littlejohn, T.G., Medrano, J.F., Vilanova, D., Roberts, M.A. Gene expression databases and data mining. Biotechniques, March, Suppl:36-44, 2003.

[26] Yang, Y.H., Dudoit, S., Luu, P., Lin, D.M., Peng, V., Ngai, J., Speed, T.P. Normalization for cDNA microarray data: a robust composite method addresing single and multiple slide systematic variation. Nucleic Acids Res 2002, 30:e15.

[27] Baird, D., Johnstone, P., Wilson, T. Normalization of microarray data using a spatial mixed model analysis which includes splines. Bioinformatics. 17:3196-205, 2004.

[28] Wang, J., Ma, J.Z., Li M.D. Normalization of cDNA microarray data using wavelet regressions. Combinatorial Chemistry \& High Throughput Screening 2004, 9:783-791.

[29] R/Bioconductor. Disponível em <http://www.bioconductor.org/>. Acesso em 20/02/2011.

[30] R-Project. Disponível em <http://www.r-project.org>. Acesso em 06/08/2010.

[31] Keller, A., Backes, C., Al-Awadhi, M., Gerasch, A., Küntzer, J., Kohlbacher, O., Kaufmann, M., Lenhof, H.P. GeneTrailExpress: a web-based pipeline for the statistical evaluation of microarray experiments. BMC Bioinformatics, 9:552, 2008.

[32] DMV. Disponível em <http://gaggle.systemsbiology.net/docs/geese/dmv.php>. Acesso em $01 / 10 / 2010$.

[33] GeneSifter. Disponível em < http://www.geospiza.com/Products/AnalysisEdition.shtml>. Acesso em 30/03/2011.

[34] Spotfire. Disponível em <http://spotfire.tibco.com/>. Acesso em 20/02/2011.

[35] Lee, H.K., Braynen, W., Keshav, K., Pavlidis, P. ErmineJ: Tool for functional analysis of gene expression data sets, BMC Bioinformatics 2005, 6:269 doi:10.1186/1471-2105-6-269.

[36] Saeed, A.I., Sharov, V., White, J., Li J., Liang, W., Bhagabati, N., Braisted, J., Klapa, M., Currier, T., Thiagarajan, M., Sturn, A., Snuffin, M., Rezantsev, A., Popov, D., Ryltsov, A., Kostukovich, E., Borisovsky, I., Liu, Z., Vinsavich, A., Trush, V., Quackenbush, J. TM4: 
a free, open-source system for microarray data management and analysis. Institute for Genomic Research, Rockville, MD, USA.

[37] Fujita A., Sato J.R., Sogayar M.C., Ferreira C.E. GEDI: a user-friendly toolbox for analysis of large-scale gene expression data. BMC Bioinformatics, 8:457, 2007.

[38] Ingenuit system pathway analysis. Disponível em <http://www.ingenuity.com/>. Acesso em 30/03/2011.

[39] Bonneau, R., Reiss, D. S., Shannon, P., Facciotti, M., Hood, L., Baliga, N.S., Thorsson, $\mathrm{V}$. The Inferelator: an algorithm for learning parsimonious regulatory networks from systemsbiology data sets de novo. Genome Biology 2006, 7:R36 doi:10.1186/gb-2006-7-5-r36

[40] Kanehisa, M., Goto, S., Kawashima, S., Nakaya, A. The KEGG databases at GenomeNet. Nucleic Acids Res. 30, 42-46 (2002).

[41] Karp, P.D., Ouzounis C.A., Moore-Kochlacs C., Goldovsky L., Kaipa P., Ahren D., Tsoka S., Darzentas N., Kunin V. e Lopez-Bigas N. "Expansion of the BioCyc collection of pathway/genome databases to 160 genomes,"

[42] Tomlinson, C., Thimma, M., Alexandrakis, S., Castillo, T., Dennis, J.L., Brooks, A., Bradley, T., Turnbull, C., Blaveri, E., Barton, G., Chiba, N., Maratou, K., Soutter, P., Aitman, T. and Game, L. MiMiR--an integrated platform for microarray data sharing, mining and analysis. BMC Bioinformatics, 9:379, 2008.

[43] Blast. Disponível em <http://blast.ncbi.nlm.nih.gov/Blast.cgi>. Acesso em 20/02/2011.

[44] ClustalW. Disponível em <http://www.ebi.ac.uk/Tools/msa/clustalw2/>. Acesso em 20/02/2011.

[45] Garlan, D., Allen, R., Ockerbloom, J. Architectural Mismatch or Why it's hard to build systems out of existing parts. IEEE Software, 12(6), pp. 17-26, 1995.

[46] Perry, D.E., Wolf, A.L. Foundations for the study of software architecture. ACM SIGSOFT Software Engineering Notes, 17(4), pp. 40-52, 1992.

[47] Shaw, M., DeLine, R., Klein, D.V., Ross, T.L., Young, D.M. and Zelesnik, G. Abstractions for Software Architecture and Tools to Support Them. IEEE Transactions on Software Engineering, 21(4), pp. 314-335, 1995.

[48] Silva Filho, A.M. Arquitetura de software: uma nova área em ciência da computação. Revista Espaço acadêmico - Ano II - No 16 - Setembro/2002 - Mensal - ISSN 1519.6186 
[49] Garlan D., Monroe R., Wile D. ACME: An Architecture Description Interchange Language. Proceedings of CASCON'97, November 1997.

[50] Allen, R.J. A formal Approach to Software Architecture. Carnegie Mellon University Pittsburgh, USA. ISBN:0-591-64744. Maio - 1997.

[51] Garlan, D. An Introduction to the Aesop System, 1995. Disponível em: $<$ http://www.cs.cmu.edu/afs/cs/project/able/www/aesop/html/aesopoverview.ps $>$. Acesso em $18 / 10 / 2010$.

[52] Medvidovic, N., Taylor, R.N. A Classification and Comparison Framework for Software Architecture Description Languages. IEEE Transactions on Software Engineering, 26(1), pp. 70-93, 2000.

[53] Medvidovic, N., Oreizy P., Robbins J.E., Taylor R.N. Using Object-Oriented Typing to Support Architectural Design in the C2 Style. Proceedings of ACM SIGSOFT'96: Fourth Symposium on the Foundations of Software Engineering (FSE4), pages 24-32, San Francisco, CA, October 1996.

[54] Mehta, N.R., Medvidovic, N., Phadke, S. Towards a taxonomy of software connectors. In Proceedings of the 22nd International Conference on Software Engineering (ICSE'00), pp.178-187, 2000.

[55] Guizzardi, G. Ontological Foundations for Structural Conceptual Models. PhD Thesis, University of Twente, 2005.

[56] van Heijst, G., Schreiber, A. Th., Wielinga, B. J. Using explicit ontologies in KBS development. International Journal of Human-Computer Studies, 46(2-3), pp. 183-292, 1997.

[57] Guarino, N. Formal Ontology and Information Systems. In Proceedings of International Conference on Formal Ontology in Information Systems (FOIS'98), IOS Press, pp. 3-15, 1998.

[58] Berners-Lee, T., Hendler, J., Lassila, O. The Semantic Web, Scientific American, May, 2001.

[59] Bachmann, A., Hesse, W., Rub, A., Kop, C., Mayr, H. C., Vöhringer, J. OBSE - an approach to Ontology-based Software Engineering in the practice. In Proceedings of the $2^{\text {nd }}$ International Workshop on Enterprise Modelling and Information Systems Architectures (EMISA'07), pp. 129-142, 2007. 
[60] Hesse, W. Ontologies in the Software Engineering process. In Proceedings of the 2nd GI-Workshop on Enterprise Application Integration (EAI'05), pp. 3-15, 2005. Disponível em $<$ http://sunsite.informatik.rwth-aachen.de/Publications/CEUR-WS/Vol-141>. Acesso em 23/11/2010.

[61] Gruber, T. Toward Principles for the Design of Ontologies Used for Knowledge Sharing. International Journal Human-Computer Studies, 43(5-6), pp. 907-928, 1995.

[62] Spyns, P., Meersman, R., Jarrar, M. Data modelling versus ontology engineering. ACM SIGMOD Record, 31(4), pp. 12-17, 2002.

[63] Ferreira Pires, L., van Sinderen, M., de Farias, C.R.G., Almeida, J.P.A. Use of Models and Modelling Techniques for Service Development. In Mendes, M. de J., Suomi, R., Passos, C. (Org.), Digital Communities in a Networked Society: eCommerce, eGovernment and eBusiness. Kluwer Academic Publishers, pp. 441-456, 2004.

[64] Ashburner, M., et al. Gene Ontology: tool for the unification of biology. Nat Genet. 25(1):25-29, 2000.

[65] Foundational Model of Anatomy. Disponível em <http://sig.biostr.washington. edu/projects/fm/>. Acesso em 20/03/2011.

[66] Eilbeck K., Lewis S.E., Mungall C.J., Yandell M., Stein L., Durbin R., Ashburner M. Sequence Ontology: a tool for the unification of genome annotations. Genome Biology, 2005, 6:R44 doi:10.1186/gb-2005-6-5-r44.

[67] Whetzel, P.L., Parkinson, H., Causton, H.C., Fan, L., Fostel, J., Fragoso, G., Game, L., Heiskanen, M., Morrison, N., Rocca-Serra, P., Sansone, S.A., Taylor, C., White, J., Stoeckert, C.J.Jr. The MGED Ontology: a resource for semantics-based description of microarray experiments. Bioinformatics, 22(7), pp. 866-873, 2006.

[68] Lefranc, M.P., Giudicelli, V., Regnier, L. and Duroux, P. IMGT, a system and an ontology that bridge biological and computational spheres in bioinformatics. Briefings in Bioinformatics, 9(4), pp. 263-275, 2008.

[69] Martin, R.F., Mejino, J.L.V., Bowden, D.M., Brinkley, J.F., Rosse, C. Foundational Model of Neuroanatomy: Implications for the Human Brain Project. American Medical Informatics Association Fall Symposium, pages pp. 438-442, 2001.

[70] Cook, D.L., Mejino, J.L. V., Neal, M.L., Gennari, J.H. Bridging Biological Ontologies and Biosimulation: The Ontology of Physics for Biology. American Medical Informatics Association Fall Symposium, pages pp. 136-140, 2008. 
[71] Travillian, R.S., Gennari, J.H. e Shapiro, L.G. Of Mice and Men: Design of a Comparative Anatomy Information System. American Medical Informatics Association Fall Symposium, 2005.

[72] Mejino J.L.V., Rubin D.L., Brinkley J.F. FMA-RadLex: An Application Ontology of Radiological Anatomy derived from the Foundational Model of Anatomy Reference Ontology. AMIA 2008 Symposium Proceedings pages: 465-469

[73] Brazma, A., Hingamp, P., Quackenbush, J., Sherlock, G., Spellman, P., Stoeckert, C., Aach, J., Ansorge, W., Ball, C.A., Causton, H.C., Gaasterland, T., Glenisson, P., Holstege, F.C., Kim, I.F.,Markowitz, V., Matese, J.C., Parkinson, H., Robinson, A., Sarkans, U., Schulze-Kremer, S., Stewart, J., Taylor, R., Vilo, J., Vingron, M. Minimum information about a microarray experiment (MIAME)-toward standards for microarray data. Nature Genetics, 2001 Dec, 29(4):365-71.

[74] Spellman, P.T. et al. Design and implementation of microarray gene expression markup language (MAGE-ML). Genome Biology, 3(9):research0046.1-0046.9, 2002.

[75] Smith, B., Ashburner, M., Rosse, C., Bard, J., Bug, W., Ceusters, W., Goldberg, L. J., Eilbeck, K., Ireland, A., Mungall, C.J., The OBI Consortium, Leontis, N., Rocca-Serra, P., Ruttenberg, A., Sansone, S.A., Scheuermann, R.H., Shah, N., Whetzel, P.L., Lewis, S. The OBO Foundry: coordinated evolution of ontologies to support biomedical data integration. Nature Biotechnology 25, 1251 - 1255, Novembro, 2007, doi: 10.1038/nbt1346.

[76] OMG. Gene Expression Specification, Version 1.1. OMG Adopted Specification, 2003.

[77] Baker, P.G., Goble, C.A, Bechhofer, S., Paton, N.W., Stevens, R., Brass, A. An ontology for bioinformatics applications. Bioinformatics, 15(6):p. 510-520, 1999.

[78] Pérez-Rey, D., Maojo, V., García-Remesal, M., Alonso-Calvo, R., Billhardt, H., MartinSánchez, F., Sousa, A. ONTOFUSION: Ontology-based integration of genomic and clinical databases. Computers in Biology and Medicine, 36(7-8), pp. 712-730, 2006.

[79] Guizzardi, G. and Halpin, T. Ontological Foundations for Conceptual Modeling. Applied Ontology, 3(1-2), pp.91-110, 2008.

[80] Fernández-López, M., Gómez-Pérez, A. Overview and analysis of methodologies for building ontologies. The Knowledge Engineering Review, 17(2), pp. 129-156, 2002.

[81] Uschold, M., King, M. Towards a methodology for building ontologies. Workshop Held in Conjunction with IJCAI on Basic Ontological Issues in Knowledge Sharing, 1995. Disponível em <http://citeseer.nj.nec.com/uschold95toward.html>. 
[82] Grüninger, M., Fox, M.S. Methodology for the design and evaluation of ontologies. Workshop on Basic Ontological Issues in Knowledge Sharing, 1995. Disponível em <http://www.eil.utoronto.ca/enterprisemodelling/papers/gruninger-ijcai95.pdf>.

[83] Fernández, M., Gómez-Pérez, A., Juristo, N. METHONTOLOGY: from ontological art towards ontological engineering. AAAI Spring Symposium on Ontological Engineering 33-40, 1997. Disponível em <http://delicias.dia.fi.upm.es/ miembros/ASUN/SSS97.ps>.

[84] Bernaras A., Laresgoiti I., Corera J., "Building and reusing ontologies for electrical network applications" - Proceedings of the European Conference on Artificial Intelligence (ECAI'96) 298-302, 1996.

[85] David, Osumi-Sutherland. OBO Format FlyBase. University of Cambridge, Downing Street, Cambridge CB2, 3EH, UK on January 22, 2010.

[86] XML. Disponível em <http://www.w3pdf.com/W3cSpec/XML/2/REC-xml11-20060816. pdf>. Acesso em 02/02/2011.

[87] Knublauch, H. A Semantic Web Primer for Object-Oriented Software Developers. December 2005. Editors' Draft. Disponível em: <http://www.w3.org/2001/sw/ BestPractices/SE/ODSD/20051217>. Acesso em 03/11/2010.

[88] OMG. OMG Unified Modeling Language Infrastructure, Version 2.4 - Beta 2, OMG Available Specification, 2011.

[89] OMG. OMG Unified Modeling Language Superstructure, Version 2.4 - Beta 2, OMG Available Specification, 2011.

[90] Patel-Schneider, P.F., Hayes, P. and Horrocks, I. (eds). OWL Web Ontology Language Semantics and Abstract Syntax. W3C Recommendation, 2004. Disponível em: $<$ http://www.w3.org/TR/owl-semantics/>. Acesso em 03/11/2010.

[91] OMG. Meta Object Facility (MOF) Core Specification, Version 2.4 - Beta 2. OMG Specification, 2011.

[92] McGuinness D.L., van Harmelen, F. OWL Web Ontology Language Overview. Editors, W3C Recommendation, 10 Fevereiro 2004. Última versão disponível em $<$ http://www.w3.org/TR/owl-features/>.

[93] Shannon, P.T., Reiss, D.J., Bonneau, R., Baliga, N.S. The Gaggle: An open-source software system for integrating bioinformatics software and data sources. BMC Bioinformatics 7:176 doi:10.1186/1471-2105-7-176, 2006. 
[94] Vêncio, R.Z.N., Bretani, H., Pereira, C.A.B. Using credibility intervals instead of hypothesis tests in SAGE analysis, Bioinformatics, 19, 2461-2464 (2003).

[95] Okamoto, O.K., Carvalho, A.C.S.R., Marti, L.C., Vêncio, R.Z., Moreira-Filho, C.A. Common molecular pathways involved in human CD133+/CD34+ progenitor cell expansion and cancer. Cancer Cell Int. 2007; 7: 11.

[96] Pascal, L.E., Vêncio, R.Z.N., Vessella, R.L., Ware, C.B., Vêncio, E.F., Denyer, G., Liu, A.Y. Lineage relationship of prostate cancer cell types based on gene expression. BMC Med Genomics. 2011; 4: 46.

[97] Huang, D.W., Sherman, B.T., Lempicki, R.A. Systematic and integrative analysis of large gene lists using DAVID Bioinformatics Resources. Nature Protoc. 2009;4(1):44-57.

[98] Teste t. Disponível em <http://www.socialresearchmethods.net/kb/stat_t.php>. Acesso em 18/04/2011.

[99] Martin, L., Anguita, A., Maojo, V., Bonsma, E., Bucur, A., Vrijnsen, J., Brochhausen, M., Cocos, C., Stenzhorn, H., Tsiknakis, M., Doerr, M., Kondylakis, H., Ontology based Integration of Distributed and Heterogeneous Data, Sources in ACGT. HEALTHINF 2008, Funchal, Portugal. 


\section{APÊNDICE A - Desenvolvimento do conector entre as ferramentas DMV e RGui - Primeiro estudo de caso.}

O primeiro estudo de caso envolve a integração das ferramentas Data MatrixView (DMV), RGui e TMeV. Dois conectores são responsáveis por essa integração. $\mathrm{O}$ conector $\mathrm{C}_{1}$ é o responsável pela integração das ferramentas DMV e RGui. Os principais aspectos da aplicação da abordagem nesse estudo de caso, com o objetivo de promover o desenvolvimento desse conector, estão especificados neste apêndice.

DMV é uma ferramenta desenvolvida na linguagem de programação Java que possibilita, em geral, carregar, exibir, selecionar e explorar dados numéricos gerados por experimentos de larga escala. A linguagem R é utilizada, em geral, como ferramenta para realizar análise exploratória de dados, cálculos estatísticos e gráficos. RGui é uma interface gráfica que possibilita a utilização dessa linguagem.

\section{A1. Identificação das principais funcionalidades das ferramentas envolvidas}

Listagem funcional da ferramenta DMV:

DMV 1 : Importar dados. Esses dados devem estar contidos em arquivo de texto com formato delimitado por tabulações ou em um repositório de dados. Os dados importados são carregados pela ferramenta.

$\mathbf{D M V}_{\mathbf{2}}$ : Exibir dados em uma planilha eletrônica.

$\mathbf{D M V}_{\mathbf{3}}$ : Ajustar largura das colunas da planilha.

$\mathbf{D M V}_{4}$ : Dispor dados em ordem alfanumérica considerando o cabeçalho de cada linha de dados.

DMV $_{\text {5: }}$ Selecionar todos os dados exibidos na planilha.

DMV 6 : Selecionar subconjunto dos dados exibidos a partir de algum critério de seleção. Por exemplo, selecionar dados cujos valores estão acima de um limiar determinado pelo usuário.

DMV $_{7}$ : Criar nova planilha com os dados selecionados.

DMV : Aplicar operações do tipo AND, OR e AVG nos dados selecionados. O resultado é gerado em uma nova linha inserida na planilha.

DMV : Plotar dados selecionados em gráfico de duas dimensões. O resultado é exibido em uma nova guia. 
DMV $_{10}$ : Buscar correlação entre dados selecionados. O resultado é exibido em uma nova guia.

DMV 11: Limpar seleção dos dados.

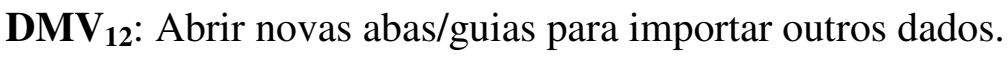

DMV 13: Exportar dados selecionados em arquivos. Esses dados são exportados em um arquivo de texto com formato delimitado por tabulações.

\section{Listagem funcional da ferramenta RGui:}

$\mathbf{R}_{\mathbf{1}}$ : Importar dados. Esses dados devem estar contidos em arquivo cujo formato é aceito por esta ferramenta. Os dados importados são carregados pela mesma.

$\mathbf{R}_{2}$ : Importar pacotes de funções. Essas funções ficam disponíveis para serem utilizadas por esta ferramenta.

$\mathbf{R}_{3}$ : Disponibilizar uma coleção integrada de ferramentas para análise de dados.

$\mathbf{R}_{\mathbf{4}}$ : Aplicar facilidades gráficas para exibição de dados.

$\mathbf{R}_{5}$ : Exportar dados em arquivo. $\mathrm{O}$ formato desse arquivo deve ser especificado pelo usuário.

$\mathrm{R}$ pode ser utilizado como um sistema de estatísticas. O usuário pode implementar uma nova função ou utilizar funções disponíveis nos dados.

$\mathbf{R}_{\mathbf{6}}$ : Aplicar função de normalização nos dados.

$\mathbf{R}_{7}$ : Aplicar funções aritméticas nos dados utilizando os seguintes operadores: "+", "-", "*", "^", "\%\%", "\%/\%", "/".

$\mathbf{R}_{\mathbf{8}}$ : Aplicar funções de comparação nos dados utilizando os seguintes operadores: "==", ">", "<", "!=", "<=", ">=".

$\mathbf{R}_{\mathbf{9}}$ : Aplicar funções lógicas nos dados utilizando os seguintes operadores: "\&", "I".

$\mathbf{R}_{10}$ : Aplicar funções matemáticas nos dados utilizando: "abs", "sign", "sqrt", "ceiling", "floor", "trunc", "cummax", "cummin", "cumprod", "cumsum", "log", "log10", "log2", "log1p", "acos", "acosh", "asin", "asinh", "atan", "atanh", "exp", "expm1", "cos", "cosh", "sin", "sinh", "tan", "tanh", "gamma", "lgamma", "digamma", "trigamma", "round", "signif".

$\mathbf{R}_{11}$ : Aplicar funções de sumarização nos dados utilizando: "max", "min", "range", "prod", "sum", "any", "all".

$\mathbf{R}_{12}$ : Aplicar função para realizar teste de hipóteses: "teste t". 


\section{A2. Descrição inicial do cenário de integração}

Subconjunto de funcionalidades diretamente relacionadas ao cenário de integração:

DMV 1 : Importar dados. Esses dados devem estar contidos em arquivo de texto com formato delimitado por tabulações ou em um repositório de dados. Os dados importados são carregados pela ferramenta.

$\mathbf{D M V}_{\mathbf{2}}$ : Exibir dados em uma planilha eletrônica.

DMV 6 : Selecionar subconjunto dos dados exibidos a partir de algum critério de seleção. Por exemplo, selecionar dados cujos valores estão acima de um limiar determinado pelo usuário.

DMV 13: Exportar dados selecionados em arquivos. Esses dados são exportados em um arquivo de texto com formato delimitado por tabulações.

$\mathbf{R}_{\mathbf{1}}$ : Importar dados. Esses dados devem estar contidos em arquivo cujo formato é aceito por esta ferramenta. Os dados importados são carregados pela mesma.

$\mathbf{R}_{\mathbf{5}}$ : Exportar dados em arquivo. O formato desse arquivo deve ser especificado pelo usuário.

$\mathbf{R}_{\mathbf{6}}$ : Aplicar função de normalização nos dados.

O cenário envolve a integração de serviços providos pela ferramenta DataMatrixView (DMV) e o ambiente integrado da linguagem R (RGui). A ferramenta DMV é utilizada para selecionar, a partir de algum critério, um subconjunto de dados. RGui é utilizado para realizar a normalização dos dados. Inicialmente o usuário da ferramenta DMV importa dados contidos em arquivo texto (formato delimitado por tabulações). Esses dados são carregados em uma matriz e disponibilizados para uso $\left(\mathbf{D M V} \mathbf{V}_{\mathbf{1}}\right)$. Com os dados carregados, DMV exibe os mesmos em uma planilha eletrônica $\left(\mathbf{D M V}_{2}\right)$. O usuário escolhe um valor de threshold (limiar) como critério de seleção de um subconjunto de dados. Apenas os dados que possuem valores acima desse limiar são selecionados $\left(\mathbf{D M V} \mathbf{V}_{\mathbf{6}}\right)$. O usuário então exporta o subconjunto de dados selecionados em um arquivo texto com formato delimitado por tabulações $\left(\mathbf{D M V}_{\mathbf{1 3}}\right)$.

Após filtragem de dados, o arquivo gerado por DMV deve ser processado (verificado e validado) para que possa ser aceito pelo ambiente integrado da linguagem $\mathrm{R}$ (RGui). O usuário da ferramenta RGui importa os dados filtrados pela ferramenta DMV, realizando alguma transformação se necessário. Esses dados são carregados em uma matriz e disponibilizados para uso $\left(\mathbf{R}_{\mathbf{1}}\right)$. Em seguida o usuário normaliza esses dados utilizando uma função de normalização disponível em RGui $\left(\mathbf{R}_{\mathbf{6}}\right)$. Finalmente o usuário exporta os dados normalizados em arquivo texto com formato delimitado por tabulações $\left(\mathbf{R}_{\mathbf{5}}\right)$. 


\section{A3. Descrição detalhada do cenário de integração}

A Figura 20 ilustra o diagrama de atividades elaborado a partir da descrição inicial do cenário de integração. As atividades "Importação de dados contidos em arquivo”, "Exibição dos dados em planilha eletrônica", "Seleção de dados a partir de um threshold" e “Exportação dos dados selecionados em arquivo” são realizadas pelo DMV. A atividade "Processamento dos dados" é realizada pelo conector, enquanto que as atividades "Importação de dados contidos em arquivo", "Normalização dos dados" e "Exportação dos dados normalizados em arquivo” são realizadas pela ferramenta RGui.

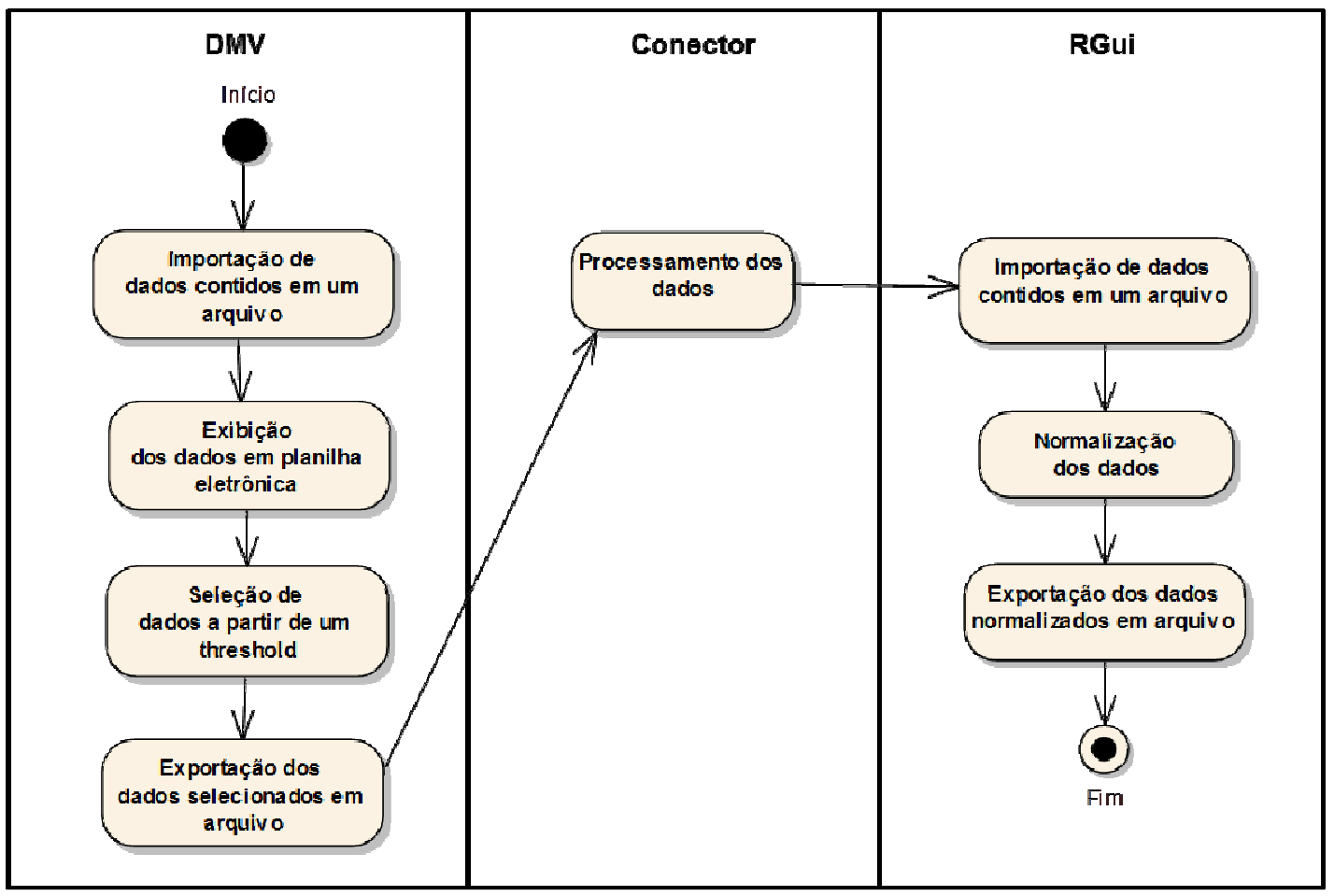

Figura 20: Diagrama de atividades relacionado ao desenvolvimento do conector $C_{1}$ (primeiro estudo de caso)

A Figura 21 ilustra os casos de uso derivados do diagrama de atividades. Os casos de uso "Importar dados de arquivos e carregar em uma matriz", "Exibir matriz de dados em planilha eletrônica", "Selecionar dados com valores acima de threshold” e "Exportar dados selecionados em arquivo" estão associados à ferramenta DMV. O caso de uso "Processar dados" está associado ao conector, enquanto que os casos de uso "Importar dados de arquivos e carregar em uma matriz", "Normalizar dados" e "Exportar dados normalizados em arquivo" estão associados à ferramenta RGui. Os casos de uso de interesse foram 
identificados em cinza. A descrição detalhada desses casos de uso é apresentada na seção A3.1.

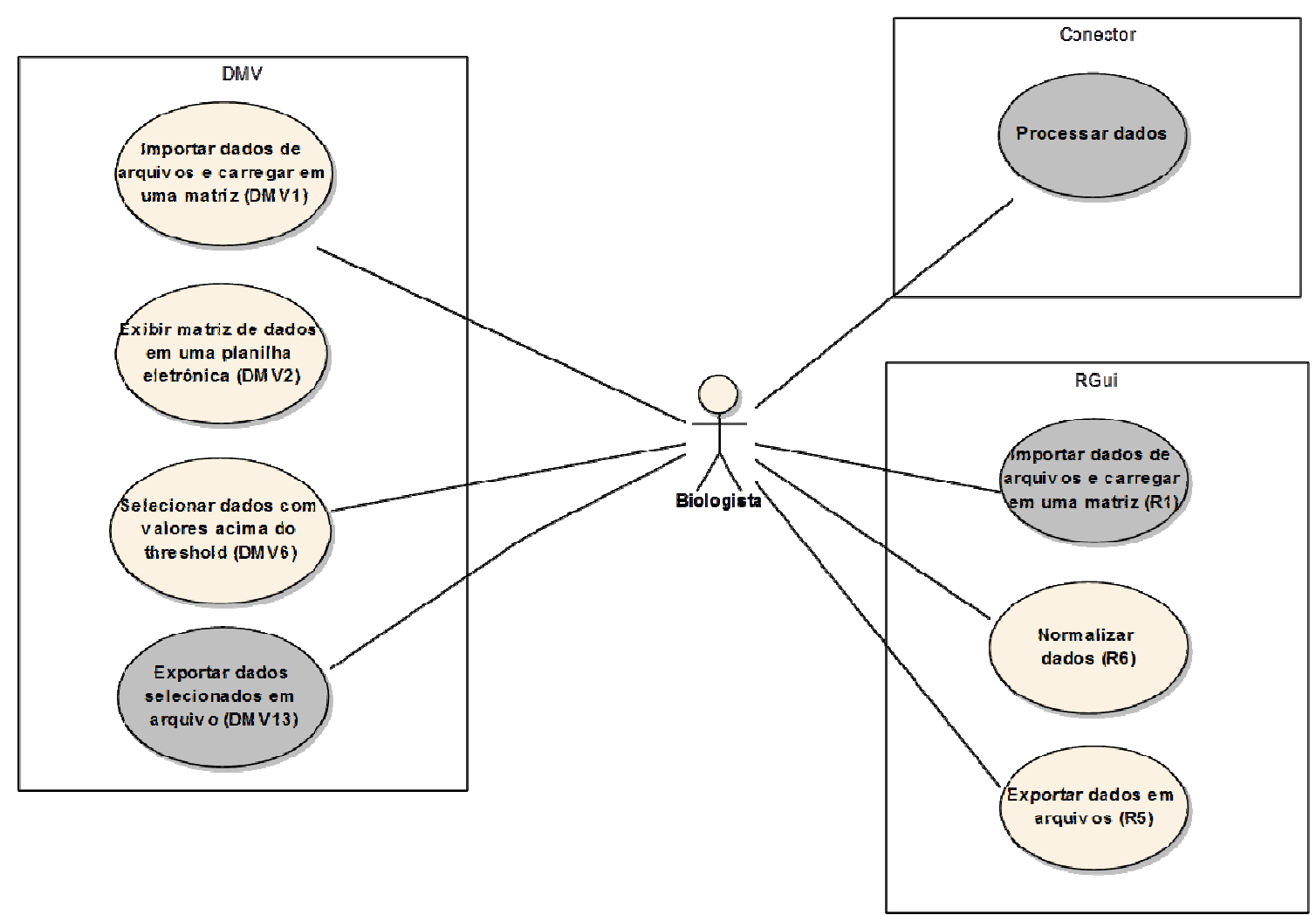

Figura 21: Diagrama de casos de uso relacionado ao desenvolvimento do conector $C_{1}$ (primeiro estudo de caso)

\section{A3.1. Casos de uso expandido}

\begin{tabular}{|l|l|}
\hline Caso de Uso & Exportar dados selecionados em arquivo (DMV) \\
\hline Atores & Biologista (iniciador) \\
\hline Finalidade & $\begin{array}{l}\text { Exportar dados de interesse, selecionados a partir de algum critério, em } \\
\text { um arquivo texto com formato delimitado por tabulações. }\end{array}$ \\
\hline Visão Geral & $\begin{array}{l}\text { O biologista opta por exportar em um arquivo um subconjunto de dados } \\
\text { que foram selecionados a partir de algum critério. O biologista deve } \\
\text { definir o nome do arquivo e o diretório onde o mesmo será gravado. Por } \\
\text { fim, o arquivo é gerado. }\end{array}$ \\
\hline
\end{tabular}

Sequência típica de eventos

\begin{tabular}{|l|l|}
\hline \multicolumn{1}{|c|}{ Ação do Ator } & \multicolumn{1}{c|}{ Resposta do sistema } \\
\hline $\begin{array}{l}\text { 1. Este caso de uso é iniciado quando o } \\
\text { biologista requisita a exportação de } \\
\text { dados previamente selecionados. }\end{array}$ & $\begin{array}{l}\text { 2. O sistema requisita nome do arquivo e } \\
\text { o diretório onde o mesmo será } \\
\text { armazenado. }\end{array}$ \\
\hline $\begin{array}{l}\text { 3. O biologista informa o nome e o } \\
\text { diretório de armazenamento do arquivo. }\end{array}$ & $\begin{array}{l}\text { 4. O sistema cria um arquivo texto com } \\
\text { formato delimitado por tabulações no } \\
\text { diretório especificado contendo os }\end{array}$ \\
\hline
\end{tabular}


dados selecionados.

\begin{tabular}{|l|l|}
\hline Caso de Uso & Processar dados (Conector) \\
\hline Atores & Biologista (iniciador) \\
\hline Finalidade & Processamento dos dados para serem utilizados pela ferramenta RGui. \\
\hline Visão Geral & $\begin{array}{l}\text { O biologista opta por realizar a integração das ferramentas DMV e } \\
\text { RGui. O conector é responsável por realizar o processamento dos dados } \\
\text { de modo a possibilitar essa integração. Neste caso o processamento } \\
\text { envolve a verificação e a validação dos dados. Por fim, a ferramenta } \\
\text { RGui é ativada. }\end{array}$ \\
\hline
\end{tabular}

Sequência típica de eventos

\begin{tabular}{|l|l|}
\hline \multicolumn{1}{|c|}{ Ação do Ator } & \multicolumn{1}{c|}{ Ação do sistema } \\
\hline $\begin{array}{l}\text { 1. Este caso de uso é iniciado quando o } \\
\text { biologista informa a localização do } \\
\text { arquivo contendo os dados de entrada e o } \\
\text { diretório esperado de armazenamento dos } \\
\text { dados de saída e requisita a integração } \\
\text { das ferramentas DMV e RGui. }\end{array}$ & $\begin{array}{l}\text { 2. O sistema realiza a verificação e } \\
\text { validação dos dados. }\end{array}$ \\
\hline & $\begin{array}{l}\text { 3. O sistema cria um arquivo contendo os } \\
\text { dados de saída. }\end{array}$ \\
\hline
\end{tabular}

Sequência alternativa de eventos

\begin{tabular}{|l|l|}
\hline \multicolumn{1}{|c|}{ Ação do Ator } & \multicolumn{1}{c|}{ Resposta do sistema } \\
\hline $\begin{array}{l}\text { 1. Este caso de uso é iniciado quando o } \\
\text { biologista informa a localização do } \\
\text { arquivo contendo os dados de entrada e o } \\
\text { diretório esperado de armazenamento dos } \\
\text { dados de saída e requisita a integração } \\
\text { das ferramentas DMV e RGui. O } \\
\text { biologista também requisita a ativação } \\
\text { automática da ferramenta RGui. }\end{array}$ & 2. O sistema realiza a verificação e \\
validação dos dados.
\end{tabular}

\begin{tabular}{|l|l|}
\hline Caso de Uso & Importar dados de arquivos e carregar em uma matriz (RGui) \\
\hline Atores & Biologista (iniciador) \\
\hline Finalidade & $\begin{array}{l}\text { Carregar dados contidos em arquivo para que possam ser normalizados } \\
\text { pela ferramenta RGui. }\end{array}$ \\
\hline Visão Geral & $\begin{array}{l}\text { O biologista opta por importar dados contidos em arquivos que devem } \\
\text { estar em um dos formatos aceitos pela ferramenta. Esses dados são } \\
\text { carregados para que possam ser manipulados pela ferramenta RGui. } \\
\text { Neste cenário de integração, os dados são carregados para serem } \\
\text { normalizados. }\end{array}$ \\
\hline
\end{tabular}


Sequência típica de eventos

\begin{tabular}{|l|l|}
\hline \multicolumn{1}{|c|}{ Ação do Ator } & \multicolumn{1}{c|}{ Resposta do sistema } \\
\hline $\begin{array}{l}\text { 1. Este caso de uso é iniciado quando o } \\
\text { biologista requisita a importação de } \\
\text { dados contidos em um arquivo. }\end{array}$ & $\begin{array}{l}\text { 2. O sistema informa os arquivos } \\
\text { existentes em um dado diretório e } \\
\text { requisita a seleção do arquivo desejado. }\end{array}$ \\
\hline $\begin{array}{l}\text { 3. O biologista informa o arquivo que } \\
\text { contém os dados de interesse. }\end{array}$ & $\begin{array}{l}\text { 4. Caso o arquivo esteja em um formato } \\
\text { aceito pelo sistema, os dados contidos } \\
\text { no arquivo são carregados para serem } \\
\text { normalizados. }\end{array}$ \\
\hline
\end{tabular}

Sequência alternativa de eventos

\begin{tabular}{|c|c|}
\hline Ação do Ator & Resposta do sistema \\
\hline $\begin{array}{l}\text { 1. Este caso de uso é iniciado quando o } \\
\text { biologista requisita a importação de } \\
\text { dados contidos em um arquivo. }\end{array}$ & $\begin{array}{l}\text { 2. O sistema informa os arquivos } \\
\text { existentes em um dado diretório e } \\
\text { requisita a seleção do arquivo desejado. }\end{array}$ \\
\hline $\begin{array}{l}\text { 3. O biologista informa o arquivo que } \\
\text { contém os dados de interesse. }\end{array}$ & $\begin{array}{l}\text { 4. Caso o arquivo não esteja em um } \\
\text { formato aceito pelo sistema, uma } \\
\text { mensagem de erro é exibida. }\end{array}$ \\
\hline
\end{tabular}

\section{A4. Descrição detalhada dos dados de interesse}

A Figura 22 ilustra uma representação da integração das ferramentas DMV e RGui através do conector $\mathrm{C}_{1}$. A primeira ferramenta gera dados que serão utilizados como entrada para o conector $\mathrm{C}_{1}\left(\mathrm{EC}_{1}\right)$ enquanto que a segunda consome dados que serão produzidos pelo mesmo $\left(\mathrm{SC}_{1}\right)$. A descrição detalhada desses dados de interesse (entrada e saída associadas ao conector) está relacionada às funcionalidades $D_{M V V}$ e $R_{1}$ associadas às ferramentas $D M V$ e RGui respectivamente.

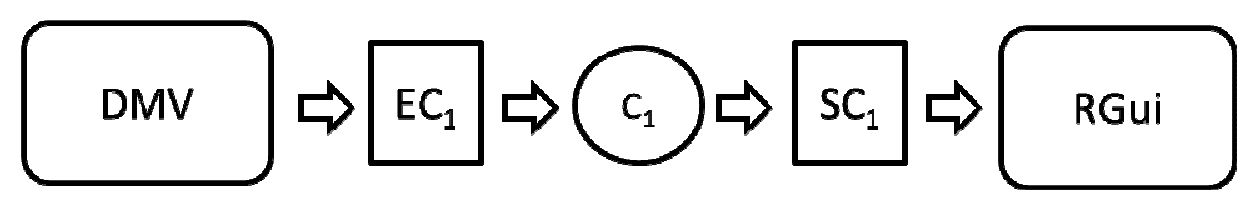

Figura 22: Integração das ferramentas DMV e RGui através do conector $C_{1}$

\section{Funcionalidade responsável por gerar os dados de entrada do conector (DMV $\left.{ }_{13}\right)$ :}

Exportar dados selecionados pela ferramenta em arquivo.

$\mathbf{E C}_{1}$ : Os dados de entrada do conector consistem nos dados gerados pela ferramenta DMV como resultado da funcionalidade $\mathrm{DMV}_{13}$ e devem estar contidos em arquivo texto com formato delimitado por tabulações. Esses dados devem consistir de dados selecionados pela ferramenta DMV e estar representados por uma matriz na qual cada linha deve representar um 
gene e cada coluna uma condição experimental. Os valores da matriz devem associar um gene a uma condição e consistir de valores numéricos de expressão gênica de microarray. A Tabela 1 apresenta a descrição desses dados.

Tabela 1: Descrição dos dados de saída relacionados à funcionalidade $\mathrm{DMV}_{13}$

\begin{tabular}{|c|c|c|}
\hline Item de dado & Descrição semântica & Sintaxe de representação \\
\hline $\begin{array}{r}\text { Valor de } \\
\text { expressão gênica }\end{array}$ & $\begin{array}{l}\text { Dado que representa um valor de expressào } \\
\text { gènica associado a um gene dada uma condiçào } \\
\text { experimernlyl }\end{array}$ & $\begin{array}{l}\text { Conjunto de valores do tipo ponto flutuante contidos em } \\
\text { uma matriz de dados de um arquivo texto delimitado por } \\
\text { lalulaçoses }\end{array}$ \\
\hline $\begin{array}{r}\text { Identificador de } \\
\text { um gene }\end{array}$ & $\begin{array}{l}\text { Dado que representa um identificador de um } \\
\text { gene }\end{array}$ & $\begin{array}{l}\text { Conjunto de valores do tipo String apresentados na primeira } \\
\text { coluna da matriz de dados }\end{array}$ \\
\hline $\begin{array}{r}\text { Condição } \\
\text { experimental }\end{array}$ & $\begin{array}{l}\text { Dado que descreve a condiçào experimental na } \\
\text { qual um dado valor de expressão gènica foi } \\
\text { obtido }\end{array}$ & $\begin{array}{l}\text { Conjunto de valores do tipo String apresentados na primeira } \\
\text { linha da matriz de dados }\end{array}$ \\
\hline
\end{tabular}

Funcionalidade responsável por consumir os dados de saída do conector $\left(\mathbf{R}_{1}\right)$ : Importar dados de arquivos para realizar a normalização dos mesmos.

SC $_{1}$ : Os dados de saída do conector consistem nos dados consumidos pela ferramenta RGui através da funcionalidade $R_{1}$ e devem estar contidos em arquivos texto cujo formato é delimitado por tabulações. A descrição desses dados é a mesma associada aos dados de entrada do conector (veja Tabela 1) e deve consistir de uma matriz em que cada linha deve representar um gene e cada coluna uma condição experimental. Os valores da matriz devem associar um gene a uma condição e consistir de valores numéricos de expressão gênica de microarray. A função de normalização, disponível pela ferramenta RGui, será aplicada nesses dados.

\section{A5. Modelagem conceitual dos dados de interesse}

A Figura 23 ilustra a modelagem conceitual dos dados de interesse associados à entrada do conector $\left(\mathrm{EC}_{1}\right)$. A partir da descrição detalhada dos dados de interesse é possível identificar genes e condições experimentais. Cada gene é cruzado com uma condição experimental gerando valores de expressão gênica. Dessa forma, para cada valor de expressão gênica existe um gene e uma condição experimental associados.

Os seguintes conceitos foram identificados: Gene, que representa um gene cujo valor de expressão gênica foi mensurado; Condicao_Experimental, que representa a condição experimental em que os genes são submetidos para a medição da expressão gênica e Valor_Expressao_Genica, que representa um valor que quantifica o nível que um Gene está 
expresso através de uma medição relativa. Valor_Expressao_Genica foi modelado como uma classe de associação definida entre Gene e Condicao_Experimental.

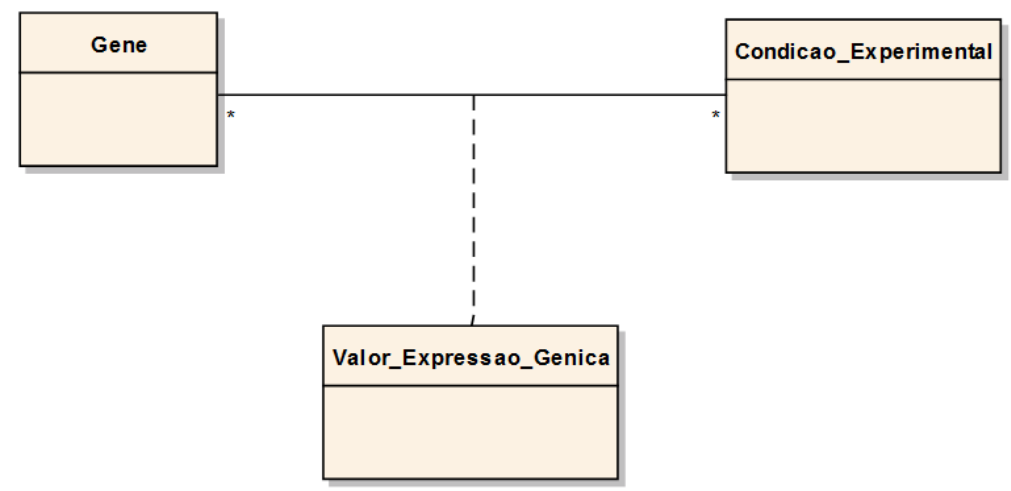

Figura 23: Modelagem conceitual associada à entrada do conector $C_{1}$ (primeiro estudo de caso)

A modelagem dos dados associados à saída do conector $\left(\mathrm{SC}_{1}\right)$ é idêntica à modelagem conceitual dos dados associados à entrada do conector (veja Figura 23). Cada linha representa um gene cujo valor de expressão gênica foi obtido de acordo com uma condição experimental representada em cada coluna.

\section{A6. Mapeamento para ontologia de referência}

A Tabela 2 apresenta o mapeamento entre os conceitos de cada modelo conceitual a conceitos da ontologia de referência. Nessa situação todos os conceitos associados à entrada $\mathrm{e}$ à saída do conector foram mapeados com sucesso para conceitos da ontologia de referência. Portanto nenhuma adequação foi necessária.

Tabela 2: Mapeamento dos conceitos associados à entrada e à saída do conector $\mathrm{C}_{1}$ (primeiro estudo de caso) aos conceitos da ontologia de referência

\begin{tabular}{|c|c|c|}
\hline $\begin{array}{c}\text { Conceito entrada } \\
\text { conector }\end{array}$ & $\begin{array}{c}\text { Conceito ontologia } \\
\text { referência }\end{array}$ & $\begin{array}{c}\text { Conceito saída } \\
\text { conector }\end{array}$ \\
\hline Expressao_Genica & RNA_Based_Value & Expressao_Genica \\
\hline Condicao_Experimental & Experimental_Condition & Condicao_Experimental \\
\hline Gene & Gene & Gene \\
\hline
\end{tabular}




\section{A7. Adequação dos dados de interesse}

A adequação sintática dos dados consiste na conversão dos dados extraídos de um arquivo texto em dados numéricos e dados textuais. A adequação semântica dos dados consiste na transformação dos dados numéricos e textuais em representações dos conceitos identificados na modelagem conceitual. Dessa forma os valores de dados numéricos devem ser associados a valores de expressão gênica, enquanto que os valores textuais devem ser associados a informações sobre genes e condições experimentais.

\section{A8. Identificação de políticas de acesso e ativação}

A ferramenta RGui disponibiliza acesso local às suas funcionalidades e pode ser instalada em qualquer diretório. Não existem restrições de acesso à ferramenta, o usuário define as configurações básicas de instalação dessa ferramenta. A transferência de controle pode ser automática ou manual a partir da execução do conector.

\section{A9. Implementação do conector}

A Figura 24 ilustra o diagrama de classes UML do conector $\mathrm{C}_{1}$. Todas as classes foram implementadas utilizando a linguagem de programação Java.

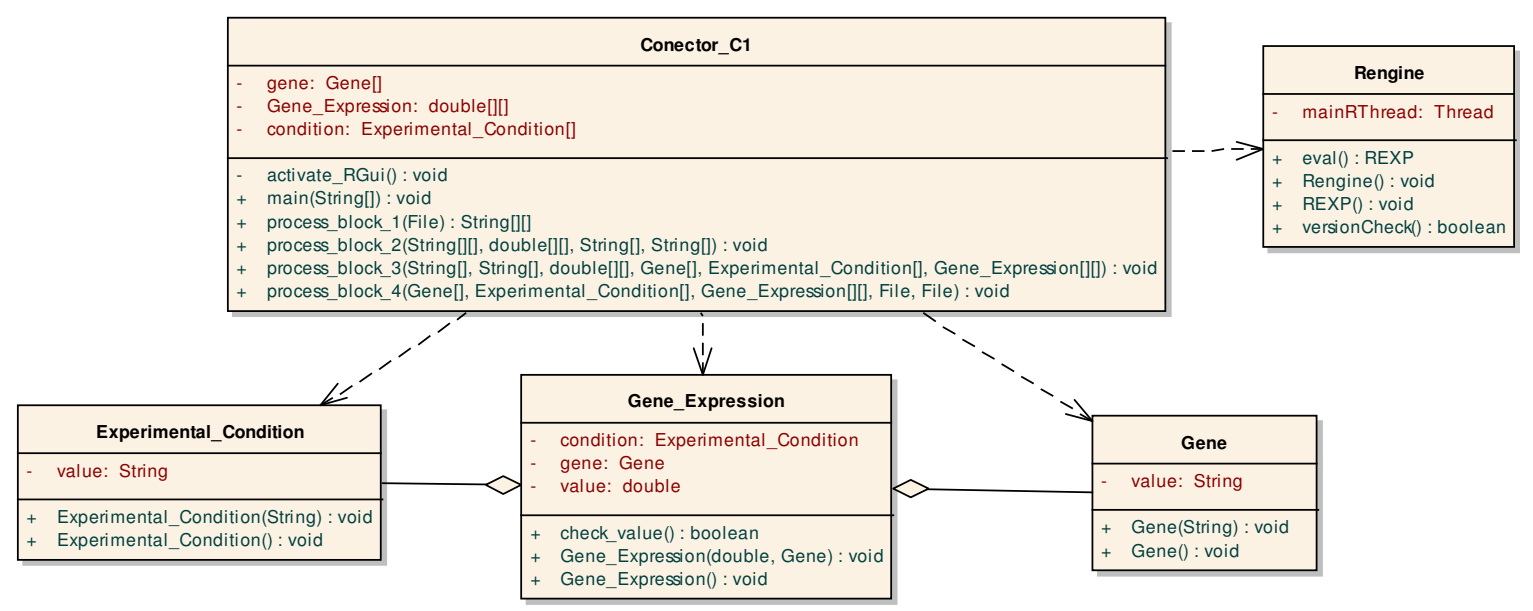

Figura 24: Diagrama de classes do conector $C_{1}$ (primeiro estudo de caso)

As classes Gene_Expression, Gene e Experimental_Condition foram criadas a partir dos conceitos identificados nos modelos conceituais. Gene é uma classe para representação de 
genes e, neste caso, armazena o identificador do gene. Experimental_Condition é uma classe para representação de condições experimentais nas quais os genes são submetidos para medição da expressão gênica. Gene_Expression é uma classe de associação para representação de valores de expressão gênica, cada um associado a um gene e uma condição experimental.

O blocos funcionais da classe Conector_C1, implementados como métodos da mesma, são executados sequencialmente, de modo que um bloco é executado somente após o término do bloco anterior. O método main recebe como parâmetros o identificador do arquivo com os dados de entrada, o identificador do diretório onde serão armazenados os dados de saída desse conector e o identificador do arquivo utilizado na ativação automática da ferramenta, se houver. O método process_block1 realiza o processamento inicial dos dados. Esse método recebe como parâmetro um identificador de arquivo (File) representando o arquivo utilizado como entrada do conector e retorna uma matriz de String que representam os dados contidos no arquivo.

O método process_block2 realiza a adequação sintática através da transformação dos dados extraídos do arquivo de entrada (matriz de String) em dados numéricos e textuais de acordo com a informação que representam. Esse método recebe como parâmetros uma matriz de String que contém os dados que foram extraídos do arquivo, uma matriz de double, que armazena os valores contidos no conteúdo da matriz, e dois vetores de String que armazenam os valores do cabeçalho contidos na primeira linha e na primeira coluna da matriz.

O método process_block3 realiza a adequação semântica através da transformação das estruturas de dados definidas e instanciadas em process_block2 em instâncias das classes criadas a partir da modelagem conceitual (associação semântica). Esse método recebe como parâmetros dois vetores de String e uma matriz de double instanciados em process_block2, um vetor de genes (Gene), um vetor de condições experimentais (Experimental_Condition) e uma matriz de valores de expressão gênica (Gene_Expression). Dessa forma, os valores contidos nos vetores de String são transformados em valores de Experimental_Condition e Gene, já os valores contidos na matriz de double são transformados em valores de Gene_Expression.

O método process_block4 realiza o processamento dos dados de saída do conector e a eventual ativação automática da ferramenta RGui. Esse método recebe como parâmetros vetores de gene(Gene), condições experimentais (Experimental_Condition), uma matriz de 
dados de expressão gênica (Gene_Expression) e dois identificadores de arquivo (File), um para identificar o diretório onde os dados de saída serão armazenados e outro para identificar o arquivo utilizado na ativação automática da ferramenta RGui. Essa ativação é implementada através da função activate_RGui e realiza a transferência de controle (passagem da thread de execução) para uma instância de RGUi executada em uma máquina virtual Java. Para realizar essa ativação são utilizados métodos disponíveis na classe Rengine que possibilitam, além de executar a ferramenta, definir quais os dados a serem carregados na inicialização da ferramenta. 


\section{APÊNDICE B - Desenvolvimento do conector entre as ferramentas RGui e TMeV - Primeiro estudo de caso.}

$\mathrm{O}$ conector $\mathrm{C}_{2}$ é o responsável pela integração das ferramentas RGui e TIGR Microarray expression Viewer (TMeV). A linguagem $\mathrm{R}$ é utilizada, em geral, como ferramenta para realizar análise exploratória de dados, cálculos estatísticos e gráficos. RGui é uma interface gráfica que possibilita a utilização dessa linguagem. TMeV é uma ferramenta desktop que realiza o processamento de dados genômicos através de uma variedade de algoritmos para clusterização, visualização, classificação e análises estatísticas.

\section{B1. Identificação das funcionalidades das ferramentas envolvidas}

Listagem funcional da ferramenta RGui:

O Apêndice A (seção A1) apresenta a listagem funcional desta ferramenta.

\section{Listagem funcional da ferramenta TMeV:}

TMEV $\mathbf{1}_{1}$ Importar dados de arquivos em formatos específicos. Esses arquivos devem estar contidos em arquivo cujo formato é aceito por esta ferramenta e são carregados pela mesma.

$\mathbf{T M E V}_{\mathbf{2}}$ : Carregar preferências para utilização desta ferramenta.

TMEV $_{3}$ : Conectar a uma base de dados.

$\mathbf{T M E V}_{4}$ : Exibir dados. Esses dados podem ser representados por único array ou por vários arrays que constituem um conjunto de dados de expressão. Os dados são exibidos em uma interface de visualização. Em geral, essa interface exibe um gráfico que representa um mapa de expressão linear ou uma matriz de distância dos genes.

TMEV 5: Imprimir ou salvar a imagem de exibição dos dados apresentada na interface de visualização desta ferramenta.

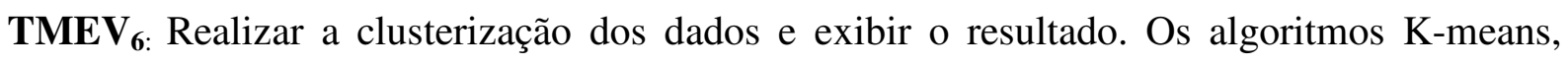
hierárquico, teste-T, análise de significância, análise de genes podem ser utilizados na clusterização.

TMEV 7 : Realizar análise estatística dos dados e exibir resultado. Os métodos TesteT, ANOVA, estimação bayesiana, ranking do produto, BRIDGE, análise de significância para dados de microarrays, testes não paramétricos podem ser utilizados na análise.

TMEV8: Classificar dados e exibir resultado. TMeV disponibiliza algoritmos de classificação como k vizinhos mais próximos, análise discriminante, classificação Shrunken, entre outros. 
TMEV9: Realizar redução dos dados e exibir resultado. Essa redução consiste da aplicação de redes de relevância, análise de componente principal, análise de correspondência e mapeamento de expressão.

TMEV $_{10}$ : Realizar meta-análise e exibir resultado. Essa meta-análise consiste da aplicação de algoritmos de análise de um conjunto de genes enriquecidos e cluster EASE.

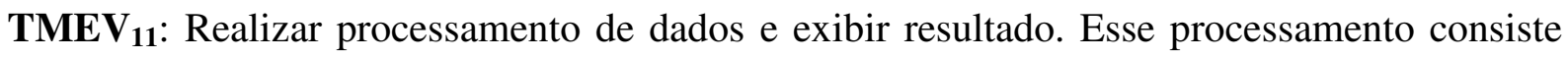
de seleção de genes, redes bayesianas e mineração de dados.

\section{B2. Descrição inicial do cenário de integração}

Subconjunto de funcionalidades diretamente relacionadas ao cenário de integração:

$\mathbf{R}_{\mathbf{1}}$ : Importar dados. Esses dados devem estar contidos em arquivo cujo formato é aceito por esta ferramenta. Os dados importados são carregados pela mesma.

$\mathbf{R}_{\mathbf{5}}$ : Exportar dados em arquivo. O formato desse arquivo deve ser especificado pelo usuário.

$\mathbf{R}_{\mathbf{6}}$ : Aplicar função de normalização nos dados.

TMEV $_{1}$ : Importar dados de arquivos em formatos específicos. Esses arquivos devem estar contidos em arquivo cujo formato é aceito por esta ferramenta e são carregados pela mesma.

TMEV $_{4}$ : Exibir dados. Esses dados podem ser representados por único array ou por vários arrays que constituem um conjunto de dados de expressão. Os dados são exibidos em uma interface de visualização. Em geral, essa interface exibe um gráfico que representa um mapa de expressão linear ou uma matriz de distância dos genes.

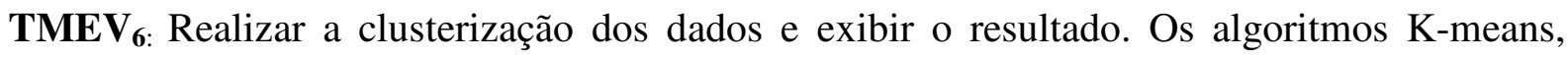
hierárquico, teste-T, análise de significância, análise de genes podem ser utilizados na clusterização.

O cenário envolve a integração de serviços providos pelo ambiente integrado da linguagem R (RGui) e a ferramenta TIGR Microarray expression Viewer (TMeV). RGui é utilizado para realizar a normalização dos dados. TMeV é utilizado para realizar a clusterização desses dados normalizados. Sugere-se que a clusterização dos dados seja aplicada em dados corretamente normalizados visando minimizar a interferência de erros associados a ruídos ou qualquer outro fator externo.

Inicialmente o usuário da ferramenta RGui importa dados contidos em arquivos texto (formato delimitado por tabulações). Esses dados são carregados por essa ferramenta e 
disponibilizados $\left(\mathbf{R}_{\mathbf{1}}\right)$. Em seguida o usuário normaliza esses dados carregados utilizando uma função de normalização disponível em RGui $\left(\mathbf{R}_{7}\right)$. O usuário então exporta os dados normalizados em um arquivo texto com formato delimitado por tabulações $\left(\mathbf{R}_{\mathbf{6}}\right)$.

Após processo de normalização de dados, o arquivo gerado por RGui deve ser processado (verificado e validado) para que possa ser aceito pela ferramenta $\mathrm{TMeV}$. O usuário da ferramenta $\mathrm{TMeV}$ importa os dados normalizados pela ferramenta RGui, contidos no arquivo processado $\left(\mathbf{T M E V}_{\mathbf{1}}\right)$. Com os dados carregados, $\mathrm{TMeV}$ exibe os mesmos em uma interface de visualização $\left(\mathbf{T} \mathbf{M E V} \mathbf{V}_{4}\right)$. O usuário escolhe um algoritmo para clusterização dos dados (por exemplo, o algoritmo K-means) e então o resultado é exibido (TMEV $\mathbf{\text { }}$ ).

\section{B3. Descrição detalhada do cenário de integração}

A Figura 25 ilustra o diagrama de atividades elaborado a partir da descrição inicial do cenário de integração. As atividades "Importação de dados contidos em arquivo”, "Normalização dos dados" e "Exportação dos dados normalizados em arquivo" são realizadas pela ferramenta RGui . A atividade "Processamento dos dados" é realizada pelo conector, enquanto que as atividades "Importação de dados de expressão gênica contidos em arquivo", "Exibição dos dados importados" e "Clusterização dos dados utilizando algoritmo K-means" são realizadas pela ferramenta $\mathrm{TMeV}$.

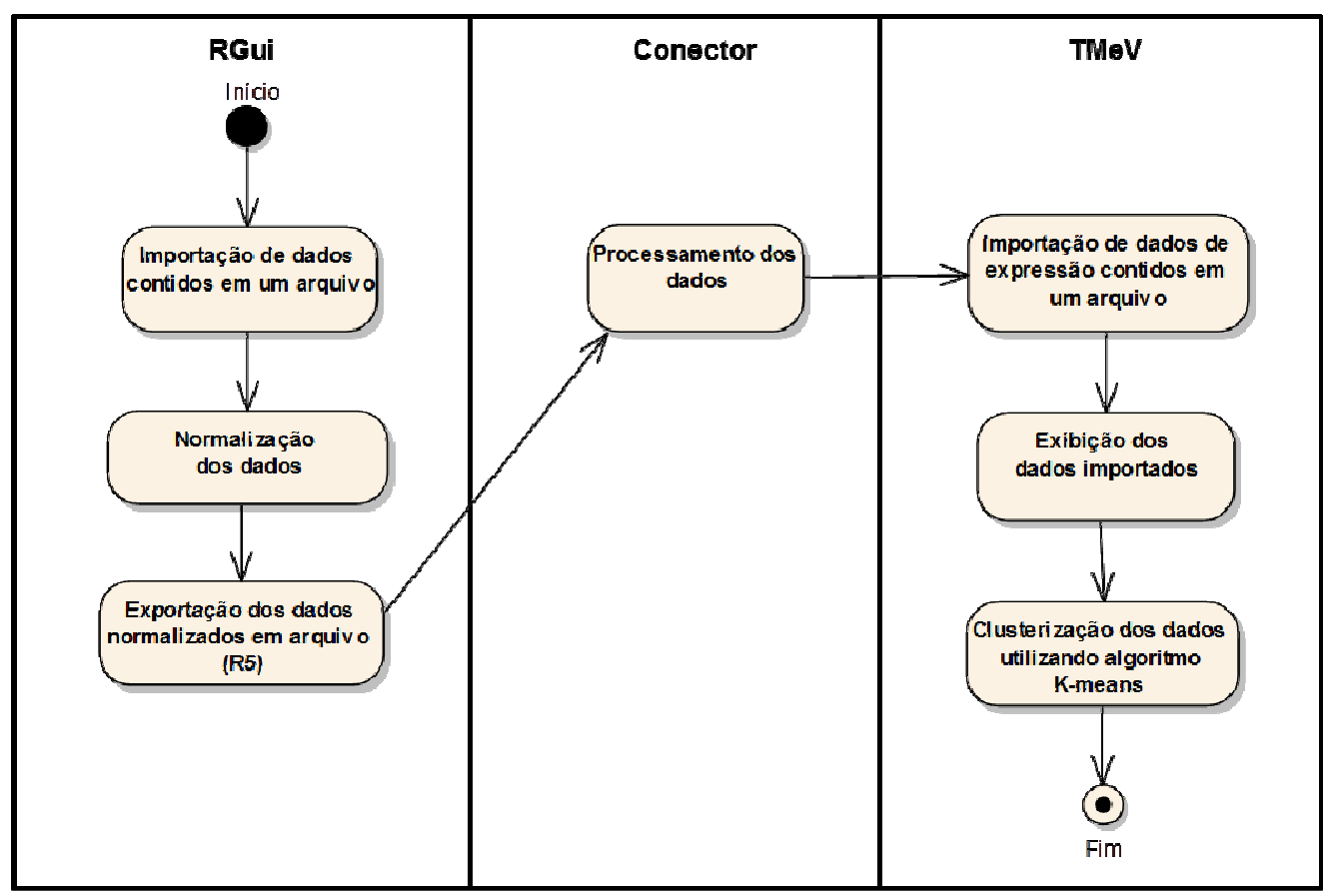

Figura 25: Diagrama de atividades relacionado ao desenvolvimento do conector $C_{2}$ (primeiro estudo de caso) 
A Figura 26 ilustra os casos de uso derivados do diagrama de atividades. Os casos de uso "Importar dados de arquivos e carregar em uma matriz", "Normalizar dados" e “Exportar dados normalizados em arquivo” estão associados à ferramenta RGui. O caso de uso "Processar dados" está associado ao conector, enquanto que os casos de uso "Importar dados de expressão de arquivos", "Exibir dados importados" e "Realizar clusterização dos dados utilizando algoritmo K-means” estão associados à ferramenta TMeV. Os casos de uso de interesse foram identificados em cinza. A descrição detalhada desses casos de uso é apresentada na seção B3.1.

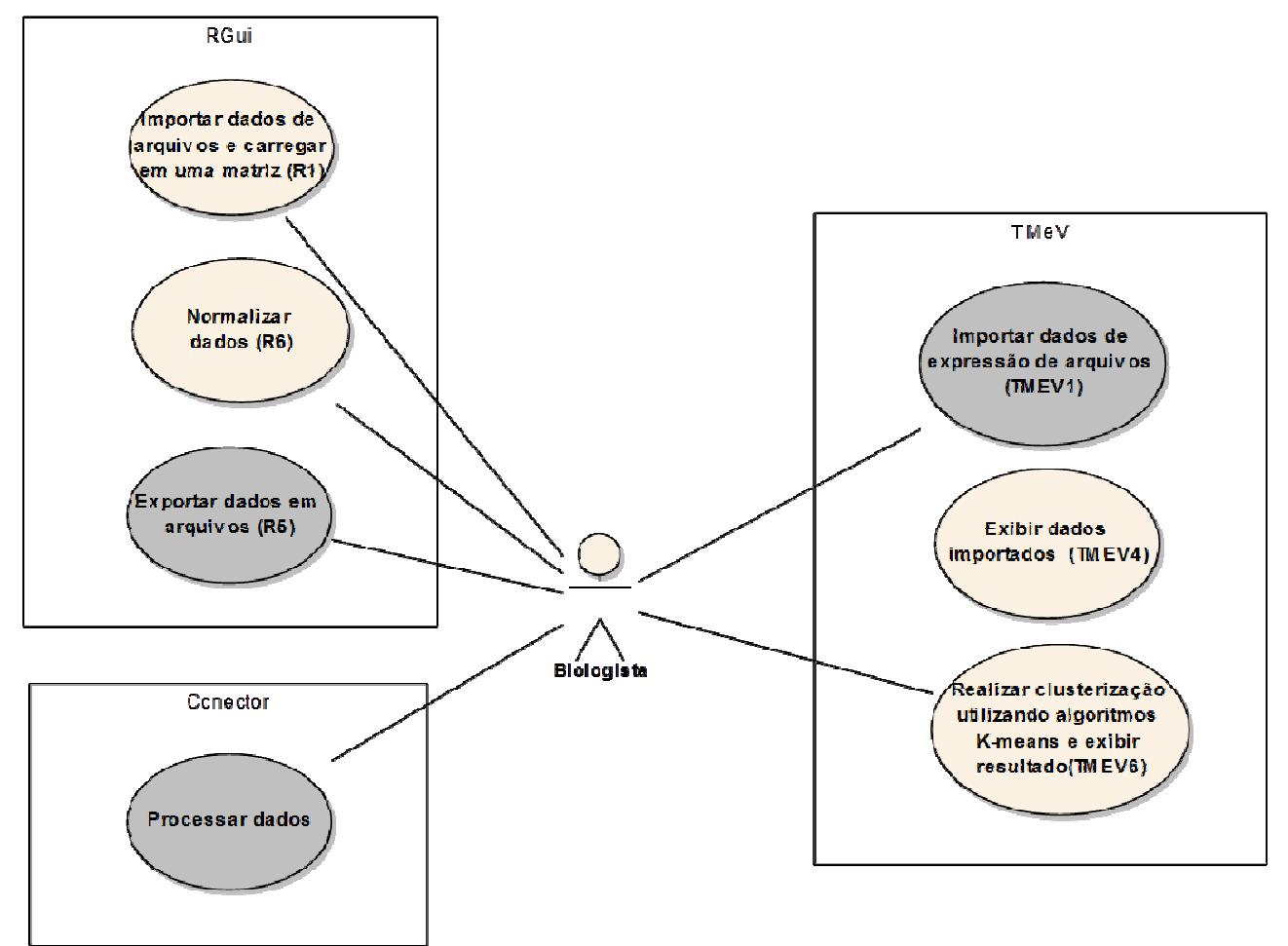

Figura 26: Diagrama de casos de uso relacionado ao desenvolvimento do conector $\mathrm{C}_{2}$ (primeiro estudo de caso)

\section{B3.1. Casos de uso expandido}

\begin{tabular}{|l|l|}
\hline Caso de Uso & Exportar dados em arquivo (RGui) \\
\hline Atores & Biologista (iniciador) \\
\hline Finalidade & $\begin{array}{l}\text { Exportar os dados normalizados pela ferramenta em um arquivo texto } \\
\text { com formato delimitado por tabulações. }\end{array}$ \\
\hline Visão Geral & $\begin{array}{l}\text { Após realizar a normalização dos dados, o biologista opta por exportar } \\
\text { os dados modificados. O biologista deve definir o nome e o diretório } \\
\text { onde o mesmo será gravado. Por fim, o arquivo é gerado. }\end{array}$ \\
\hline
\end{tabular}


Sequência típica de eventos

\begin{tabular}{|l|l|}
\hline \multicolumn{1}{|c|}{ Ação do Ator } & \multicolumn{1}{c|}{ Resposta do sistema } \\
\hline \begin{tabular}{l} 
1. $\begin{array}{l}\text { Este caso de uso é iniciado quando o } \\
\text { biologista requisita a exportação de } \\
\text { dados normalizados. }\end{array}$ \\
\hline $\begin{array}{l}\text { 3. O biologista informa o nome e o } \\
\text { diretório de armazenamento do arquivo. }\end{array}$
\end{tabular} & $\begin{array}{l}\text { 2. O sistema requisita nome do arquivo e } \\
\text { o diretório onde o mesmo será } \\
\text { armazenado. }\end{array}$ \\
\hline $\begin{array}{l}\text { O sistema cria o arquivo de texto em } \\
\text { diretório especificado contendo os } \\
\text { dados normalizados. }\end{array}$ \\
\hline
\end{tabular}

\begin{tabular}{|l|l|}
\hline Caso de Uso & Processar dados (Conector) \\
\hline Atores & Biologista (iniciador) \\
\hline Finalidade & $\begin{array}{l}\text { Processamento dos dados de modo a serem utilizados pela ferramenta } \\
\text { TMeV. }\end{array}$ \\
\hline Visão Geral & $\begin{array}{l}\text { O biologista opta por realizar a integração das ferramentas RGui e } \\
\text { TMeV. O conector é responsável por realizar o processamento dos } \\
\text { dados de modo a possibilitar essa integração. Neste caso o } \\
\text { processamento envolve a verificação e a validação dos dados. Por fim, a } \\
\text { ferramenta TMeV é ativada. }\end{array}$ \\
\hline
\end{tabular}

Sequência típica de eventos

\begin{tabular}{|l|l|}
\hline \multicolumn{1}{|c|}{ Ação do Ator } & \multicolumn{1}{c|}{ Ação do sistema } \\
\hline $\begin{array}{l}\text { 1. Este caso de uso é iniciado quando o } \\
\text { biologista informa a localização do } \\
\text { arquivo contendo os dados de entrada e } \\
\text { diretório esperado de armazenamento dos } \\
\text { dados de saída e requisita a integração } \\
\text { das ferramentas RGui e TMeV. }\end{array}$ & $\begin{array}{l}\text { 2. O sistema realiza a verificação e } \\
\text { validação dos dados. }\end{array}$ \\
\hline & $\begin{array}{l}\text { 3. O sistema cria um arquivo contendo os } \\
\text { dados de saída. }\end{array}$ \\
\hline
\end{tabular}

Sequência alternativa de eventos

\begin{tabular}{|l|l|}
\hline \multicolumn{1}{|c|}{ Ação do Ator } & \multicolumn{1}{|c|}{ Resposta do sistema } \\
\hline $\begin{array}{l}\text { 1. Este caso de uso é iniciado quando o } \\
\text { biologista informa a localização do } \\
\text { arquivo contendo os dados de entrada e } \\
\text { diretório esperado de armazenamento dos } \\
\text { dados de saída e requisita a integração } \\
\begin{array}{l}\text { das ferramentas RGui e TMeV. O } \\
\text { biologista também requisita a ativação } \\
\text { automática da ferramenta TMeV. }\end{array}\end{array}$ & $\begin{array}{l}\text { 2. O sistema realiza a verificação e } \\
\text { validação dos dados. }\end{array}$ \\
\hline & $\begin{array}{l}\text { 3. O sistema cria um arquivo contendo os } \\
\text { dados de saída. }\end{array}$ \\
\hline & $\begin{array}{l}\text { 4. O sistema realiza a ativação automática } \\
\text { da ferramenta TMeV. }\end{array}$ \\
\hline
\end{tabular}




\begin{tabular}{|l|l|}
\hline Caso de Uso & $\begin{array}{l}\text { Importar dados de expressão gênica de arquivos em formatos específicos } \\
\text { (TMeV) }\end{array}$ \\
\hline Atores & Biologista (iniciador) \\
\hline Finalidade & $\begin{array}{l}\text { Carregar dados contidos em arquivos para que possam ser manipulados } \\
\text { pela ferramenta. }\end{array}$ \\
\hline Visão Geral & $\begin{array}{l}\text { O biologista opta por importar dados contidos em arquivos que estejam } \\
\text { em um dos formatos aceitos pela ferramenta. Esses dados são carregados } \\
\text { pela ferramenta para que possam ser manipulados. Neste cenário de } \\
\text { integração, os dados serão carregados para serem clusterizados. }\end{array}$ \\
\hline
\end{tabular}

Sequência típica de eventos

\begin{tabular}{|l|l|}
\hline \multicolumn{1}{|c|}{ Ação do Ator } & \multicolumn{1}{c|}{ Resposta do sistema } \\
\hline $\begin{array}{l}\text { 1. Este caso de uso é iniciado quando o } \\
\text { biologista requisita a importação de } \\
\text { dados contidos em um arquivo. }\end{array}$ & $\begin{array}{l}\text { 2. O sistema informa os arquivos } \\
\text { existentes em um dado diretório e } \\
\text { requisita a seleção do arquivo desejado. }\end{array}$ \\
\hline $\begin{array}{l}\text { 3. O biologista informa o arquivo que } \\
\text { contém os dados de interesse. }\end{array}$ & $\begin{array}{l}\text { 4. Caso o arquivo esteja em um formato } \\
\text { aceito pelo sistema, os dados contidos } \\
\text { no arquivo são carregados de modo que } \\
\text { os mesmos possam ser clusterizados. }\end{array}$ \\
\hline
\end{tabular}

Sequência alternativa de eventos

\begin{tabular}{|l|l|}
\hline \multicolumn{1}{|c|}{ Ação do Ator } & \multicolumn{1}{c|}{ Resposta do sistema } \\
\hline $\begin{array}{l}\text { 1. Este caso de uso é iniciado quando o } \\
\text { biologista requisita a importação de } \\
\text { dados contidos em um arquivo. }\end{array}$ & $\begin{array}{l}\text { 2. O sistema informa os arquivos } \\
\text { existentes em um dado diretório e } \\
\text { requisita a seleção do arquivo desejado. }\end{array}$ \\
\hline $\begin{array}{l}\text { 3. O biologista informa o arquivo que } \\
\text { contém os dados de interesse. }\end{array}$ & $\begin{array}{l}\text { 4. Caso o arquivo não esteja em um } \\
\text { formato aceito pelo sistema, uma } \\
\text { mensagem de erro é exibida. }\end{array}$ \\
\hline
\end{tabular}

\section{B4. Descrição detalhada dos dados de interesse}

A Figura 27 ilustra uma representação da integração das ferramentas RGui e TMeV através do conector $\mathrm{C}_{2}$. A primeira ferramenta gera os dados que servirão de entrada para conector $\mathrm{C}_{2}\left(\mathrm{EC}_{2}\right)$ enquanto que a segunda consome dados que serão produzidos pelo mesmo $\left(\mathrm{SC}_{2}\right)$. A descrição detalhada desses dados de interesse (entrada e saída associadas ao

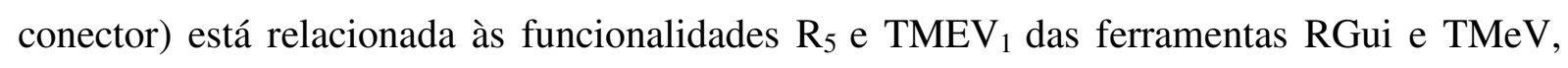
respectivamente.

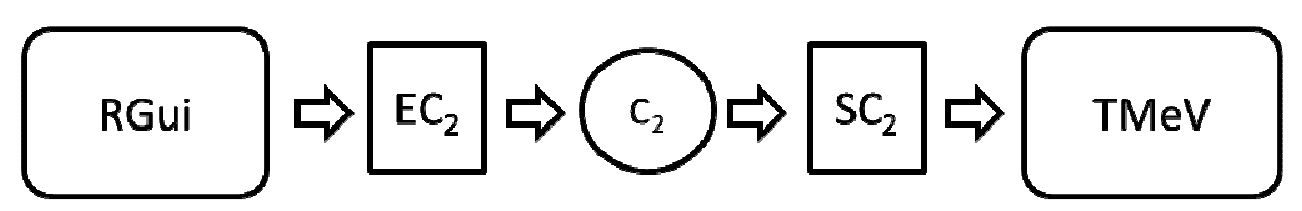

Figura 27: Integração das ferramentas RGui e TMeV através do conector $\mathrm{C}_{2}$ 
Funcionalidade responsável por gerar os dados de entrada do conector $\left(\mathbf{R}_{\mathbf{5}}\right)$ : Exportar dados normalizados pela ferramenta em arquivo.

$\mathbf{E C}_{2}$ : Os dados de entrada do conector consistem nos dados gerados pela ferramenta RGui como resultado da funcionalidade $\mathrm{R}_{5}$ e devem estar contidos em arquivo texto com formato delimitado por tabulações. Esses dados devem consistir de dados normalizados pela ferramenta RGui e estar representados por uma matriz na qual cada linha deve representar um gene e cada coluna uma condição experimental. Os valores da matriz devem associar um gene a uma condição e consistir de valores numéricos de expressão gênica de dados de microarray. A Tabela 3 apresenta a descrição desses dados.

Tabela 3: Descrição dos dados relacionados à saída da funcionalidade $\mathbf{R}_{5} \mathbf{e}$ à entrada do conector $\mathbf{C}_{2}$

\begin{tabular}{|c|c|c|}
\hline Item de dado & Descrição semântica & Sintaxe de representação \\
\hline $\begin{array}{r}\text { Valor de } \\
\text { expressão gênica }\end{array}$ & $\begin{array}{l}\text { Dado que representa um valor de expressào } \\
\text { gênica associado a um gene dada uma condiçăo } \\
\text { cxpcrimcntal }\end{array}$ & $\begin{array}{l}\text { Conjunto de valores do tipo ponto flutuante contidos em } \\
\text { uma matriz de dados de um arquivo texto delimitado por } \\
\text { tabulacõcs }\end{array}$ \\
\hline $\begin{array}{r}\text { Identificador de } \\
\text { um gene }\end{array}$ & $\begin{array}{l}\text { Dado que representa um identificador de um } \\
\text { gene }\end{array}$ & $\begin{array}{l}\text { Conjunto de valores do tipo String apresentados na primeira } \\
\text { coluna da matriz de dados }\end{array}$ \\
\hline $\begin{array}{r}\text { Condição } \\
\text { experimental }\end{array}$ & $\begin{array}{l}\text { Dado que destreve a condição experimental na } \\
\text { qual um dado valor de expressăo gènica tói } \\
\text { obtido }\end{array}$ & $\begin{array}{l}\text { Conjumlo de valores do lipo Slring apresentados na primeira } \\
\text { linha da matriz de dados }\end{array}$ \\
\hline
\end{tabular}

\section{Funcionalidade responsável por consumir os dados gerados pelo conector $\left(\mathrm{TMEV} \mathrm{V}_{1}\right)$ :} Importar dados de arquivos em formatos específicos para realizar a clusterização dos mesmos. $\mathbf{S C}_{2}$ : Os dados de saída do conector consistem nos dados consumidos pela ferramenta TMeV através da funcionalidade $\mathrm{TMEV}_{1}$ e devem estar contidos em arquivos texto cujo formato é delimitado por tabulações. Para o cenário de integração adotado, os dados consumidos consistem de dados contidos em arquivos texto cujo formato é delimitado por tabulações. A descrição desses dados é a mesma associada aos dados de entrada do conector (veja Tabela 3) e deve consistir de uma matriz em que cada linha deve representar um gene e cada coluna uma condição experimental. Os valores da matriz deve associar um gene a uma condição e consistir de valores numéricos de expressão gênica de dados de microarray. A clusterização dos dados, disponível pela ferramenta, será aplicada nesses dados.

\section{B5. Modelagem conceitual dos dados de interesse}

A modelagem conceitual dos dados de interesse associados à entrada do conector $\mathrm{C}_{2}$ foi realizada $\left(\mathrm{EC}_{2}\right)$. A partir da descrição detalhada dos dados de interesse é possível 
identificar que a modelagem conceitual (veja Figura 28) é a mesma relacionada à entrada do conector $\mathrm{C}_{1}$.

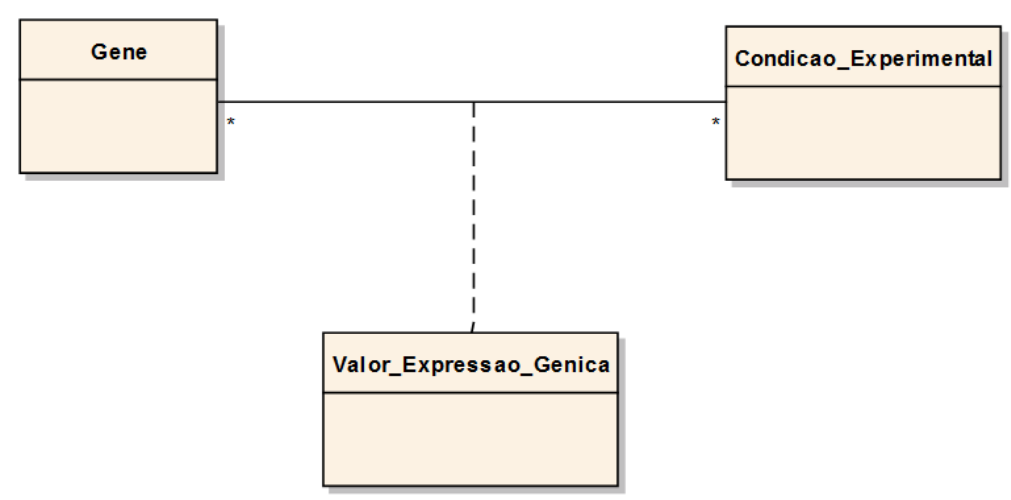

Figura 28: Modelagem conceitual associada à entrada do conector $C_{2}$ (primeiro estudo de caso)

A modelagem dos dados associados à saída do conector $\left(\mathrm{SC}_{2}\right)$ é idêntica à modelagem conceitual dos dados associados à entrada do conector (veja Figura 28). Cada linha representa um gene cujo valor de expressão gênica foi obtido de acordo com uma condição experimental representada em cada coluna.

\section{B6. Mapeamento para ontologia de referência}

A Tabela 4 apresenta o mapeamento entre os conceitos de cada modelo conceitual a conceitos da ontologia de referência. Nessa situação todos os conceitos associados à entrada e à saída do conector foram mapeados com sucesso para conceitos da ontologia de referência. Portanto nenhuma adequação foi necessária.

Tabela 4: Mapeamento dos conceitos associados à entrada e saída do conector $C_{2}$ (primeiro estudo de caso) aos conceitos da ontologia de referência

\begin{tabular}{|c|c|c|}
\hline $\begin{array}{c}\text { Conceito entrada } \\
\text { conector }\end{array}$ & $\begin{array}{c}\text { Conceito ontologia } \\
\text { referência }\end{array}$ & $\begin{array}{c}\text { Conceito saída } \\
\text { conector }\end{array}$ \\
\hline Expressao_Genica & RNA_Based_Value & Expressao_Genica \\
\hline Condicao_Experimental & Experimental_Condition & Condicao_Experimental \\
\hline Gene & Gene & Gene \\
\hline
\end{tabular}




\section{B7. Adequação dos dados de interesse}

A adequação sintática dos dados consiste na conversão dos dados extraídos de um arquivo texto em dados numéricos e dados textuais. A adequação semântica dos dados consiste na transformação dos dados numéricos e textuais em representações dos conceitos identificados na modelagem conceitual. Dessa forma os valores de dados numéricos devem ser associados a valores de expressão gênica, enquanto que os valores textuais devem ser associados a informações sobre genes e condições experimentais.

\section{B8. Identificação de políticas de acesso e ativação}

A ferramenta $\mathrm{TMeV}$ disponibiliza acesso local às suas funcionalidades e pode ser instalado em qualquer diretório. O usuário define as configurações básicas na instalação da ferramenta. Não existe restrição de acesso à mesma. A transferência de controle deve ser automática a partir da execução do conector.

\section{B9. Implementação do conector}

A Figura 29 ilustra o diagrama de classes UML do conector $\mathrm{C}_{2}$. Todas as classes foram implementadas utilizando a linguagem de programação Java.

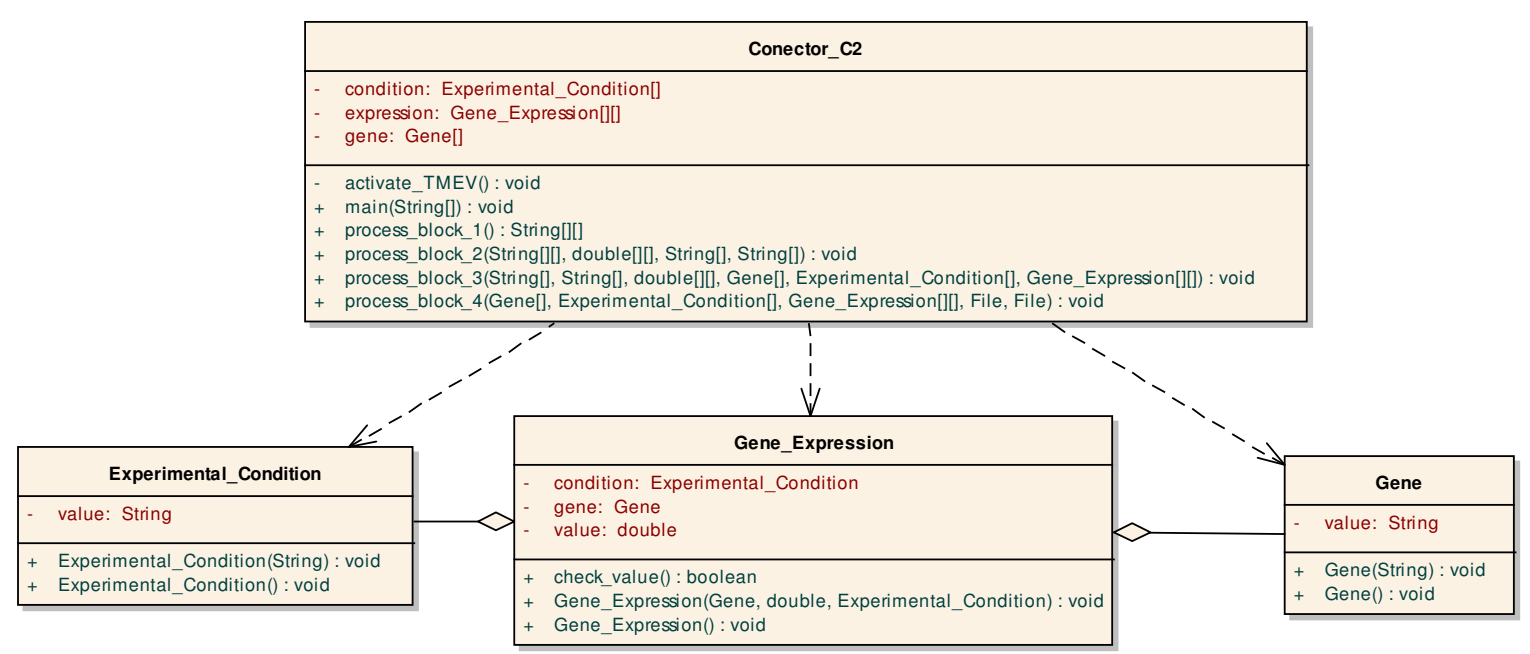

Figura 29: Diagrama de classes do conector $C_{2}$ (primeiro estudo de caso) 
As classes Gene_Expression, Gene e Experimental_Condition foram criadas a partir dos conceitos identificados nos modelos conceituais. Gene é uma classe para representação de genes e, neste caso, armazena o identificador do gene. Experimental_Condition é uma classe para representação de condições experimentais nas quais os genes são submetidos para medição da expressão gênica. Gene_Expression é uma classe de associação para representação de valores de expressão gênica, cada um associado a um gene e uma condição experimental.

Os blocos funcionais da classe Conector_C2, implementados como métodos da mesma, são executados sequencialmente, de modo que um bloco é executado somente após o término do bloco anterior. O método main recebe como parâmetros o identificador do arquivo com os dados de entrada, o identificador do diretório onde serão armazenados os dados de saída desse conector e o identificador do arquivo utilizado na ativação automática da ferramenta, se houver. O método process_blockl realiza o processamento inicial dos dados. Esse método recebe como parâmetro identificador de arquivo (File) representando o arquivo utilizado como entrada do conector e retorna uma matriz de String que representam os dados contidos no arquivo.

O método process_block2 realiza a adequação sintática através da transformação dos dados extraídos do arquivo de entrada (matriz de String) em dados numéricos e textuais de acordo com a informação que representam. Esse método recebe como parâmetros uma matriz de String que contém os dados que foram extraídos do arquivo, uma matriz de double, que armazena os valores contidos no conteúdo da matriz, e dois vetores de String que armazenam os valores do cabeçalho contidos na primeira linha e na primeira coluna da matriz.

O método process_block3 realiza a adequação semântica através da transformação das estruturas de dados definidas e instanciadas em process_block 2 em instâncias das classes criadas a partir da modelagem conceitual (associação semântica). Esse método recebe como parâmetros dois vetores de String e uma matriz de double instanciados em process_block2, um vetor de genes (Gene), um vetor de condições experimentais (Experimental_Condition) e uma matriz de valores de expressão gênica (Gene_Expression). Dessa forma, os valores contidos nos vetores de String são transformados em valores de Experimental_Condition e Gene, já os valores contidos na matriz de double são transformados em valores de Gene_Expression. 
O método process_block4 realiza o processamento dos dados de saída do conector e a eventual ativação automática da ferramenta $\mathrm{TMeV}$. Esse método recebe como parâmetros vetores de gene (Gene), condições experimentais (Experimental_Condition), uma matriz de dados de expressão gênica (Gene_Expression) e dois identificadores de arquivo (File), um para identificar o diretório onde os dados de saída serão armazenados e outro para identificar o arquivo utilizado na ativação automática da ferramenta TMeV. Essa ativação é implementada através da função activate_TMEV e realiza a transferência de controle (passagem da thread de execução) para a ferramenta TMeV através da execução de um arquivo com extensão bat como um processo. Esse arquivo bem como o código fonte dessa ferramenta são disponibilizados pelos desenvolvedores da mesma. Diferentemente da ativação da ferramenta RGui, a execução da ferramenta TMeV como um processo foi realizada já que não existem métodos que permitam inicializar a mesma com dados carregados. 


\section{APÊNDICE C - Desenvolvimento do conector responsável pela integração de um banco de dados com a ferramenta DMV - Segundo estudo de caso.}

O segundo estudo de caso envolve a integração de um banco de dados contendo informações biológicas às ferramentas DataMatrixView (DMV) e TMeV. Dois conectores serão responsáveis por essa integração. $\mathrm{O}$ conector $\mathrm{C}_{1}$ é o responsável pela integração do banco de dados do NCBI à ferramenta DMV. Os principais aspectos da aplicação da abordagem para este estudo de caso, com o objetivo de promover o desenvolvimento desse conector, estão especificados neste apêndice.

O banco de dados é um repositório de dados público que contém dados genômicos funcionais sobre experimentos e perfis de expressão gênica. A ferramenta DMV foi desenvolvida na linguagem de programação Java e possibilita, em geral, carregar, exibir, selecionar e explorar dados numéricos gerados por experimentos de larga escala.

\section{C1. Identificação das principais funcionalidades das ferramentas envolvidas}

Listagem funcional da ferramenta DMV:

O Apêndice A (seção A1) apresenta a listagem funcional desta ferramenta.

\section{C2. Descrição inicial do cenário de integração}

Subconjunto de funcionalidades diretamente relacionadas ao cenário de integração:

DMV $_{1}$ : Importar dados. Esses dados devem estar contidos em arquivo de texto com formato delimitado por tabulações ou em um repositório de dados. Os dados importados são carregados pela ferramenta.

$\mathbf{D M V}_{2}$ : Exibir dados em uma planilha eletrônica.

DMV6: Selecionar subconjunto dos dados exibidos a partir de algum critério de seleção. Por exemplo, selecionar dados cujos valores estão acima de um limiar determinado pelo usuário.

DMV $_{13}$ : Exportar dados selecionados em arquivos. Esses dados são exportados em um arquivo de texto com formato delimitado por tabulações.

O cenário envolve a integração do banco de dados do NCBI aos serviços providos pela ferramenta DataMatrixView (DMV). Os dados contidos no banco são resultados de abordagens baseadas em sequenciamento com a finalidade de obter uma medição relativa da expressão gênica. Esses dados estão estruturados em listas de String e contidos em arquivos 
texto, acessados localmente. Cada String consiste de uma sequência de bases nitrogenadas de tamanho fixo que pode aparecer diversas vezes em um mesmo arquivo. Cada arquivo é resultado de sequenciamentos obtidos de acordo com uma condição experimental.

Os dados armazenados no banco de dados são extraídos e processados em três etapas de modo a serem utilizados pela ferramenta DMV. A primeira etapa consiste na identificação de genes. Nessa etapa é feita a substituição das sequências de bases nitrogenadas pelos identificadores dos genes que essas representam em cada arquivo. Para isso é necessário realizar uma busca em um repositório de dados BLAST por cada sequência contida em cada arquivo. Caso haja associação entre a sequência de bases a algum gene conhecido, o identificador desse gene substitui o valor dessa sequência. Caso contrário, a sequência permanece inalterada no arquivo.

A segunda etapa consiste na contagem do número total de genes existentes em cada um dos arquivos, a partir das listas de genes geradas na primeira etapa. Cada lista foi obtida de acordo com uma condição experimental distinta e está contida em um arquivo. Os dados resultantes devem ser representados em uma matriz cujo cabeçalho de cada coluna contém uma condição experimental e, uma linha de dados para informar essa quantidade total. Esses dados são armazenados em um arquivo texto cujo formato é separado por tabulações.

A terceira etapa consiste na transformação dos dados contidos em diferentes arquivos, que consistem de lista de genes geradas na primeira etapa, em uma matriz de dados numéricos. Essa matriz informa o número de vezes que cada gene foi obtido de acordo com cada condição experimental. Para isso é realizada a contagem do número de vezes que cada gene está representado em cada arquivo e o resultado é armazenado em uma matriz de dados numéricos que representa um identificador de gene em cada linha e um arquivo (condição experimental) em cada coluna. Os valores dessa matriz representam a quantidade de vezes que um gene foi obtido de acordo com uma condição experimental. A matriz é armazenada em um arquivo texto cujo formato é separado por tabulações.

Após processamento dos dados, o usuário da ferramenta DMV importa os dados gerados na terceira etapa. Esses dados são carregados em uma matriz e disponibilizados para uso pela ferramenta DMV (DMV 1$)$. Com os dados carregados, DMV exibe os mesmos em uma planilha eletrônica $\left(\mathbf{D M V}_{\mathbf{2}}\right)$. O usuário escolhe um valor de threshold (limiar) como critério para seleção de um subconjunto de dados. Apenas os dados cujos valores estão acima 
desse limiar serão selecionados $\left(\mathbf{D M V} \mathbf{V}_{\mathbf{6}}\right)$. O usuário então exporta o subconjunto de dados em um arquivo texto com formato delimitado por tabulações ( $\left.\mathbf{D M V} \mathbf{V}_{\mathbf{1 3}}\right)$.

\section{C3. Descrição detalhada do cenário de integração}

A Figura 30 ilustra o diagrama de atividades elaborado a partir da descrição inicial do cenário de integração. As atividades "Identificação de genes", "Contagem do número total de genes", "Transformação dos dados em uma matriz de valores numéricos" são realizadas pelo conector, enquanto que as atividades "Seleção de dados a partir de um threshold", "Exibição dos dados em planilha eletrônica", "Importação de dados contidos em um arquivo" e "Exportação dos dados selecionados em arquivo” são realizadas pela ferramenta DMV.

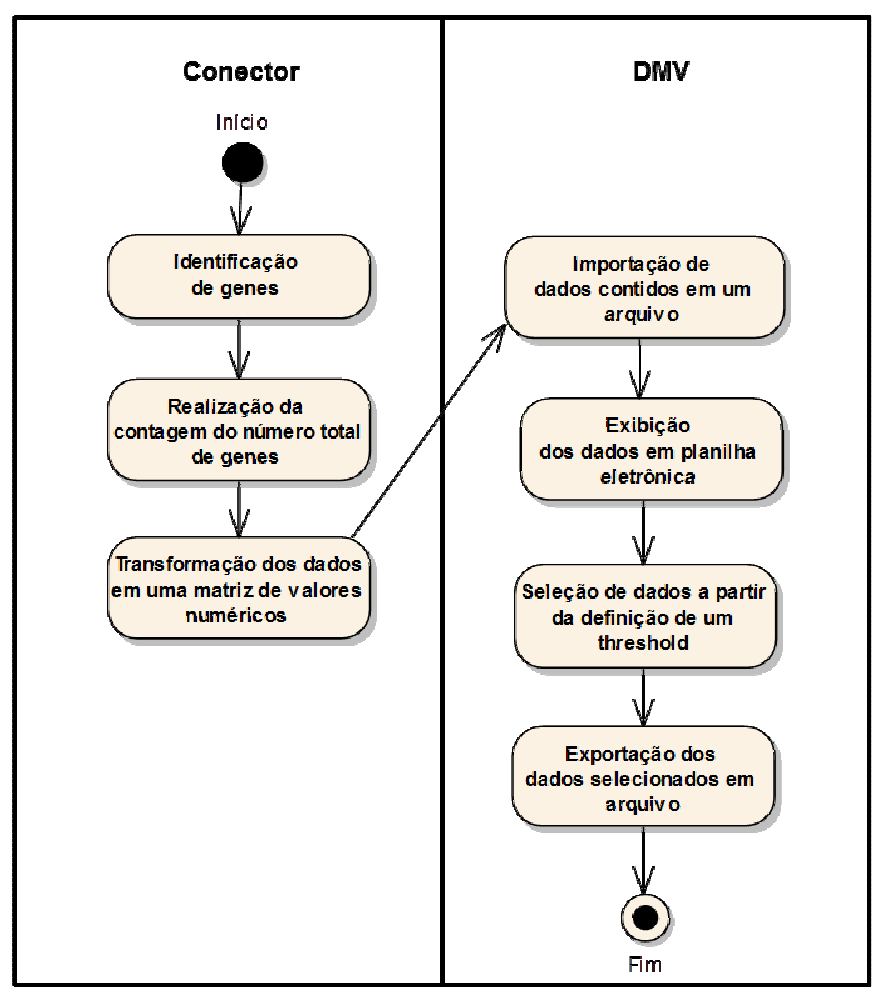

Figura 30: Diagrama de atividades relacionado ao desenvolvimento do conector $C_{1}$ (segundo estudo de caso)

A Figura 31 ilustra os casos de uso derivados do diagrama de atividades. Os casos de uso "Processar dados", "Identificar genes", "Realizar contagem total de genes" e "Transformar dados em matriz numérica” estão associados ao conector, enquanto que os casos de uso "Importar dados de arquivos e carregar em uma matriz", "Exibir matriz de dados em uma planilha eletrônica", "Selecionar dados com valores acima do threshold" e 
"Exportar dados selecionados em arquivo" estão associados à ferramenta DMV. Os casos de uso de interesse foram identificados em cinza. A descrição detalhada desses casos de uso é apresentada na seção C3.1.

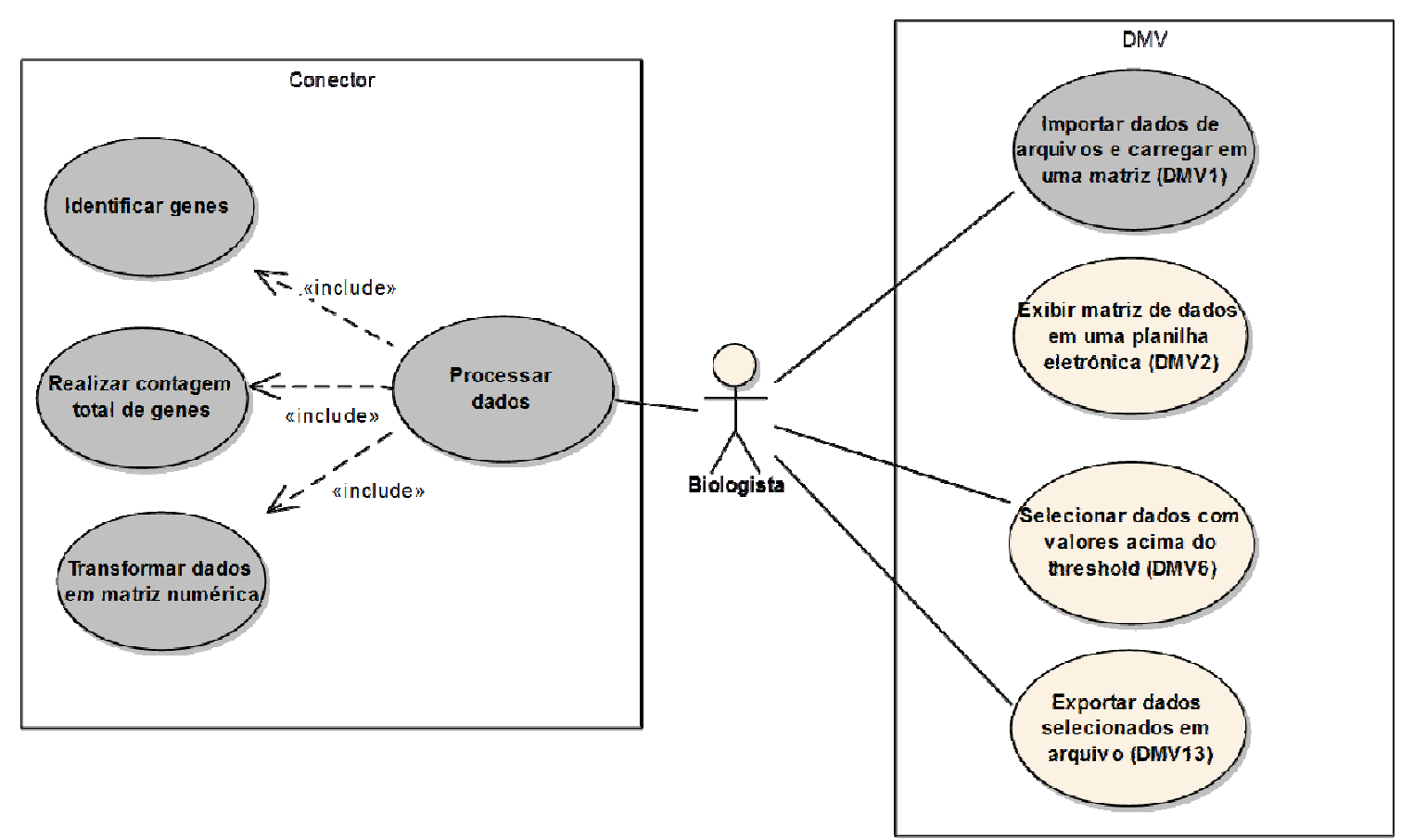

Figura 31: Diagrama de casos de uso relacionado ao desenvolvimento do conector $C_{1}$ (segundo estudo de caso)

\section{C3.1. Casos de uso expandido}

\begin{tabular}{|l|l|}
\hline Caso de Uso & Processar dados (Conector) \\
\hline Atores & Biologista (iniciador) \\
\hline Finalidade & $\begin{array}{l}\text { Recuperar e transformar dados de expressão gênica, obtidos por uma } \\
\text { abordagem baseada em sequência, de modo a serem utilizados pela } \\
\text { ferramenta DMV. }\end{array}$ \\
\hline Visão Geral & $\begin{array}{l}\text { O biologista opta por realizar a transformação dos dados objetivando a } \\
\text { integração de uma base de dados à ferramenta DMV. Essa integração é } \\
\text { realizada por um conector responsável pelo processamento dos dados. } \\
\text { Neste caso, o processamento envolve a identificação de genes, a } \\
\text { contagem total de genes e a transformação dos dados em matriz } \\
\text { numérica. Por fim, a ferramenta DMV é ativada. }\end{array}$ \\
\hline
\end{tabular}

Sequência típica de eventos

\begin{tabular}{|l|l|}
\hline \multicolumn{1}{|c|}{ Ação do Ator } & \multicolumn{1}{c|}{ Resposta do sistema } \\
\hline $\begin{array}{l}\text { 1. Este caso de uso é iniciado quando o } \\
\text { biologista informa a localização dos }\end{array}$ & $\begin{array}{l}\text { 2. O sistema executa o caso de uso } \\
\text { Identificar genes. }\end{array}$ \\
\hline
\end{tabular}




\begin{tabular}{|l|l|}
\hline $\begin{array}{l}\text { arquivos contendo os dados de entrada e } \\
\text { o diretório esperado de armazenamento } \\
\text { dos dados de saída e requisita a } \\
\text { transformação dos dados para possibilitar } \\
\text { a integração da base de dados à } \\
\text { ferramenta DMV. }\end{array}$ & \\
\hline & $\begin{array}{l}\text { 3. O sistema executa o caso de uso } \\
\text { Realizar contagem total dos genes. }\end{array}$ \\
\hline & $\begin{array}{l}\text { 4. O sistema executa o caso de uso } \\
\text { Transformar dados em matriz } \\
\text { numérica. }\end{array}$ \\
\hline
\end{tabular}

Sequência alternativa de eventos

\begin{tabular}{|l|l|}
\hline \multicolumn{1}{|c|}{ Ação do Ator } & \multicolumn{1}{c|}{ Resposta do sistema } \\
\hline $\begin{array}{l}\text { 1. Este caso de uso é iniciado quando o } \\
\text { biologista informa a localização dos } \\
\text { arquivos contendo os dados de entrada e } \\
\text { o diretório esperado de armazenamento } \\
\text { dos dados de saída e requisita a } \\
\text { transformação dos dados para possibilitar } \\
\begin{array}{l}\text { a integração da base de dados à } \\
\text { ferramenta DMV. O biologista também } \\
\text { requisita a ativação automática da } \\
\text { ferramenta DMV. }\end{array}\end{array}$ & $\begin{array}{l}\text { 2. O sistema executa o caso de uso } \\
\text { Identificar genes. }\end{array}$ \\
\hline & $\begin{array}{l}\text { 3. O sistema executa o caso de uso } \\
\text { Realizar contagem total dos genes. }\end{array}$ \\
\hline & $\begin{array}{l}\text { 4. O sistema executa o caso de uso } \\
\text { Transformar dados em matriz } \\
\text { numérica. }\end{array}$ \\
\hline & $\begin{array}{l}\text { 5. O sistema realiza a ativação automática } \\
\text { da ferramenta DMV. }\end{array}$ \\
\hline
\end{tabular}

\begin{tabular}{|l|l|}
\hline Caso de Uso & Identificar genes (Conector) \\
\hline Atores & Biologista (indireto) \\
\hline Finalidade & Identificação dos genes a partir sequências de bases nitrogenadas \\
\hline Visão Geral & $\begin{array}{l}\text { A partir de uma lista de sequências de bases nitrogenadas é feita uma } \\
\text { consulta em um banco de dados BLAST para procurar associações entre } \\
\text { cada uma dessas sequências a genes conhecidos. }\end{array}$ \\
\hline
\end{tabular}

Sequência típica de eventos

\begin{tabular}{|l|l|}
\hline \multicolumn{1}{|c|}{ Ação do Ator } & \multicolumn{1}{c|}{ Resposta do sistema } \\
\hline $\begin{array}{l}\text { 1. Este caso de uso é iniciado como } \\
\text { resultado da execução do caso de uso } \\
\text { Processar dados. }\end{array}$ & $\begin{array}{l}\text { 2. O sistema busca em um banco de dados } \\
\text { e substitui sequências de bases } \\
\text { nitrogenadas pelos respectivos }\end{array}$ \\
& $\begin{array}{l}\text { identificadores do gene caso haja } \\
\text { associação. Caso contrário nenhuma } \\
\text { alteração é realizada. }\end{array}$ \\
\hline & 3. O sistema cria um arquivo que contém \\
\hline
\end{tabular}


esses dados substituídos.

\begin{tabular}{|l|l|}
\hline Caso de Uso & Realizar contagem de genes (Conector) \\
\hline Atores & Biologista (indireto) \\
\hline Finalidade & $\begin{array}{l}\text { Contar o número total de genes obtidos de acordo com uma condição } \\
\text { experimental. }\end{array}$ \\
\hline Visão Geral & $\begin{array}{l}\text { A partir de listas de genes é feita contagem do número de genes que } \\
\text { estão contidos em cada arquivo. Esses números são armazenados em } \\
\text { uma matriz. Cada coluna representa um arquivo (condição experimental) } \\
\text { e uma linha sobre o número total de genes que aparece em cada arquivo. }\end{array}$ \\
\hline
\end{tabular}
Sequência típica de eventos

\begin{tabular}{|l|l|}
\hline \multicolumn{1}{|c|}{ Ação do Ator } & \multicolumn{1}{c|}{ Resposta do sistema } \\
\hline $\begin{array}{l}\text { 1. Este caso de uso é iniciado como } \\
\text { resultado da execução do caso de uso } \\
\text { Processar dados. }\end{array}$ & $\begin{array}{l}\text { 2. O sistema realiza a contagem do } \\
\text { número total de genes que estão } \\
\text { contidos em todos os arquivos obtidos } \\
\text { de acordo com uma condição } \\
\text { experimental e gera uma matriz para } \\
\text { armazenar esses números. }\end{array}$ \\
\hline & $\begin{array}{l}\text { 3. O sistema cria um arquivo que contém } \\
\text { essa matriz gerada. }\end{array}$ \\
\hline
\end{tabular}

\begin{tabular}{|l|l|}
\hline Caso de Uso & Transformar dados em matriz numérica (Conector) \\
\hline Atores & Biologista (indireto) \\
\hline Finalidade & Transformar listas de genes em uma matriz de números. \\
\hline Visão Geral & $\begin{array}{l}\text { A partir de listas de genes é feita contagem do número de vezes que cada } \\
\text { gene aparece em cada arquivo. Como resultado é gerado uma matriz } \\
\text { para armazenar esses valores. Cada linha representa um gene e cada } \\
\text { coluna um arquivo obtido de acordo com uma condição experimental. } \\
\text { Os valores dessa matriz informam o número de vezes que cada gene } \\
\text { aparece em cada um dos arquivos. }\end{array}$ \\
\hline
\end{tabular}

Sequência típica de eventos

\begin{tabular}{|l|l|}
\hline \multicolumn{1}{|c|}{ Ação do Ator } & \multicolumn{1}{c|}{ Resposta do sistema } \\
\hline $\begin{array}{l}\text { 1. Este caso de uso é iniciado como } \\
\text { resultado da execução do caso de uso } \\
\text { Processar dados. }\end{array}$ & $\begin{array}{l}\text { 2. O sistema identifica quais os genes são } \\
\text { únicos em todos os arquivos. }\end{array}$ \\
\hline & $\begin{array}{l}\text { 3. O sistema realiza a contagem do } \\
\text { número de vezes que cada gene } \\
\text { identificado aparece em cada arquivo e } \\
\text { armazena o resultado em uma matriz. }\end{array}$ \\
\hline & $\begin{array}{l}\text { 4. O sistema cria um arquivo que contém } \\
\text { essa matriz gerada. }\end{array}$ \\
\hline
\end{tabular}




\begin{tabular}{|l|l|}
\hline Caso de Uso & Importar dados de arquivo (DMV) \\
\hline Atores & Biologista (iniciador) \\
\hline Finalidade & $\begin{array}{l}\text { Carregar dados contidos em arquivo para que possam ser utilizados pela } \\
\text { ferramenta. }\end{array}$ \\
\hline Visão Geral & $\begin{array}{l}\text { O biologista opta por importar dados contidos em arquivos que estejam } \\
\text { em um dos formatos aceitos pela ferramenta. Esses dados são carregados } \\
\text { para que possam ser filtrados pela ferramenta DMV. }\end{array}$ \\
\hline
\end{tabular}

\section{Sequência típica de eventos}

\begin{tabular}{|l|l|}
\hline \multicolumn{1}{|c|}{ Ação do Ator } & \multicolumn{1}{c|}{ Resposta do sistema } \\
\hline $\begin{array}{l}\text { 1. Este caso de uso é iniciado quando o } \\
\text { biologista requisita a importação de } \\
\text { dados contidos em um arquivo. }\end{array}$ & $\begin{array}{l}\text { 2. O sistema informa os arquivos } \\
\text { existentes em um dado diretório e } \\
\text { requisita a seleção do arquivo desejado. }\end{array}$ \\
\hline $\begin{array}{l}\text { 3. O biologista informa o arquivo que } \\
\text { contém os dados de interesse. }\end{array}$ & $\begin{array}{l}\text { 4. Caso o arquivo esteja em um formato } \\
\text { aceito pelo sistema, os dados contidos } \\
\text { no arquivo são carregados em uma } \\
\text { matriz de modo que os mesmos possam } \\
\text { ser filtrados. }\end{array}$ \\
\hline
\end{tabular}

Sequência alternativa de eventos

\begin{tabular}{|l|l|}
\hline \multicolumn{1}{|c|}{ Ação do Ator } & \multicolumn{1}{c|}{ Resposta do sistema } \\
\hline $\begin{array}{l}\text { 1. Este caso de uso é iniciado quando o } \\
\text { biologista requisita a importação de } \\
\text { dados contidos em um arquivo. }\end{array}$ & $\begin{array}{l}\text { 2. O sistema informa os arquivos } \\
\text { existentes em um dado diretório e } \\
\text { requisita a seleção do arquivo desejado. }\end{array}$ \\
\hline $\begin{array}{l}\text { 3. O biologista informa o arquivo que } \\
\text { contém os dados de interesse. }\end{array}$ & $\begin{array}{l}\text { 4. Caso o arquivo não esteja em um } \\
\text { formato aceito pelo sistema, uma } \\
\text { mensagem de erro é exibida. }\end{array}$ \\
\hline
\end{tabular}

\section{C3.2. Refinamento arquitetônico do cenário de integração}

$\mathrm{O}$ conector $\mathrm{C}_{1}$ é responsável por realizar o caso de uso "Processar dados" que está associado às atividades de identificação dos genes, contagem do número total de genes e transformação dos dados em valores numéricos. Esse conector foi identificado como um conector composto formado por três conectores simples: $\mathrm{C}_{1.1}, \mathrm{C}_{1.2}$ e $\mathrm{C}_{1.3}$. Cada conector simples é responsável por executar um caso de uso de interesse. $\mathrm{C}_{1.1}$ é responsável pela execução do caso de uso "Identificar genes", $\mathrm{C}_{1.2}$ é responsável pela execução do caso de uso "Realizar contagem total de genes", enquanto que $\mathrm{C}_{1.3}$ é responsável pela execução do caso de uso "Transformar dados em matriz numérica". Após a transformação dos dados é possível utilizar a ferramenta DMV para "Importar dados de arquivos e carregar em uma matriz". A Figura 32 ilustra a integração do banco de dados à ferramenta DMV através do conector $\mathrm{C}_{1} \mathrm{e}$ a decomposição do mesmo em $\mathrm{C}_{1.1}, \mathrm{C}_{1.2}$ e $\mathrm{C}_{1.3}$. 


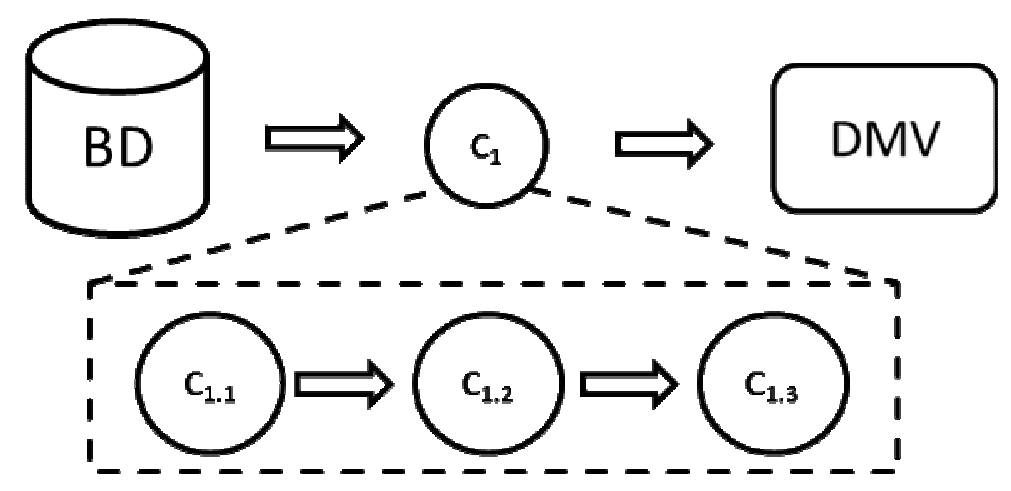

Figura 32: Integração do banco de dados à ferramenta DMV através do conector $C_{1}$

\section{C4. Descrição detalhada dos dados de interesse}

A descrição detalhada dos dados de interesse (entrada e saída associadas ao conector $\mathrm{C}_{1}$ ) envolve a descrição dos dados extraídos do banco de dados e dos dados relacionados à ferramenta DMV (funcionalidade $\mathrm{DMV}_{1}$ ). A Figura 33 ilustra uma representação da integração do banco de dados à ferramenta DMV através dos conectores $C_{1.1}, C_{1.2}$ e $C_{1.3}$ que compõem $\mathrm{C}_{1} \cdot \mathrm{EC}_{1.1}$ representa os dados extraídos do conector que servirão de entrada para o conector $\mathrm{C}_{1.1} . \mathrm{SC}_{1.1}$ representa os dados que serão produzidos pelo conector $\mathrm{C}_{1.1}$ e consumidos pelos conectores $\mathrm{C}_{1.2}$ e $\mathrm{C}_{1.3}$. $\mathrm{SC}_{1.2}$ representa os dados que serão produzidos por $\mathrm{C}_{1.2}$ e $\mathrm{SC}_{1.3}$ representa os dados que serão produzidos pelo conector $\mathrm{C}_{1.3}$ e consumidos pela ferramenta DMV. As descrições detalhadas desses dados estão especificadas para cada conector.

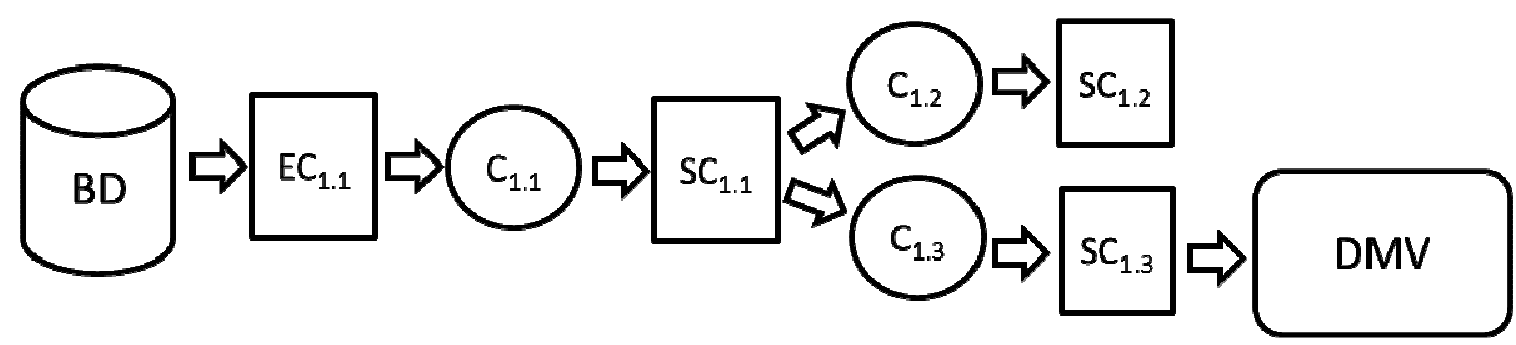

Figura 33: Representação da integração do banco de dados à ferramenta DMV através dos conectores $\mathrm{C}_{1.1}, \mathrm{C}_{1.2}$ e $\mathrm{C}_{1.3}$

\section{C4.1. Descrição detalhada dos dados de interesse associados a $C_{1.1}$}

$\mathbf{C}_{1.1}$ : Conector responsável por realizar a identificação dos genes a partir de sequências de bases nitrogenadas. 
EC $_{1.1}$ : Os dados de entrada do conector $\mathrm{C}_{1.1}$ consistem nos dados extraídos do banco de dados. Esses dados devem estar contidos em arquivos formato sra (Short Read Archive) $e$ devem representar vetores de sequências de bases nitrogenadas. Cada linha do arquivo apresenta um elemento desse vetor. Cada arquivo representa uma condição experimental na qual essas sequências foram obtidas. A Tabela 5 apresenta a descrição desses dados.

Tabela 5: Descrição dos dados de entrada do conector $C_{1.1}$

\begin{tabular}{|r|l|l|}
\hline Item de dado & \multicolumn{1}{|c|}{ Descrição semântica } & \multicolumn{1}{|c|}{ Sintaxe de representação } \\
\hline $\begin{array}{r}\text { Condição } \\
\text { experimental }\end{array}$ & $\begin{array}{l}\text { Dado que descreve a condiçào experimental na qual } \\
\text { foram obtidas sequências que podem representar } \\
\text { genes, visando obter valores de expressào gênica }\end{array}$ & $\begin{array}{l}\text { Valor do tipo String representado através do nome } \\
\text { do arquivo texto que contém os dados }\end{array}$ \\
\hline $\begin{array}{r}\text { Sequência de bases } \\
\text { nitrogenadas }\end{array}$ & $\begin{array}{l}\text { Dado que rcprcscnta uma scqućncia dc bascs } \\
\text { nitrogenadas, que por sua vez, pode representar um } \\
\text { gene conhecido }\end{array}$ & $\begin{array}{l}\text { Conjunto de valorcs do tipo String aprcscntados cm } \\
\text { listas contidas em arquivos texto delimitado por } \\
\text { tabulações }\end{array}$ \\
\hline
\end{tabular}

$\mathbf{S C}_{1.1}$ : Os dados de saída do conector $\mathrm{C}_{1.1}$ devem estar contidos em arquivos texto e devem representar vetores de identificadores de genes. Cada linha desses arquivos apresenta um identificador do gene que possui associação a uma sequência de bases nitrogenadas. Cada arquivo representa uma condição experimental na qual as sequências, associadas aos genes identificados, foram obtidas. A Tabela 6 apresenta a descrição desses dados.

Tabela 6: Descrição dos dados de saída do conector $\mathbf{C}_{1.1}$

\begin{tabular}{|r|l|l|}
\hline Item de dado & \multicolumn{1}{|c|}{ Descrição semântica } & \multicolumn{1}{|c|}{ Sintaxe de representação } \\
\hline $\begin{array}{r}\text { Condição } \\
\text { experimental }\end{array}$ & $\begin{array}{l}\text { Dado que descreve a condição experimental na qual } \\
\text { foram obtidas sequências que podem representar } \\
\text { genes, visando obter valores de expressão gênica }\end{array}$ & $\begin{array}{l}\text { Valor do tipo String representado através do nome } \\
\text { do arquivo texto que contém os dados }\end{array}$ \\
\hline $\begin{array}{r}\text { Identificador de } \\
\text { gene }\end{array}$ & Dado que representa um identificador de um gene & $\begin{array}{l}\text { Conjunto de valores do tipo String apresentados em } \\
\text { listas contidas em arquivos texto delimitado por } \\
\text { tabulações }\end{array}$ \\
\hline
\end{tabular}

\section{C4.2. Descrição detalhada dos dados de interesse associados a $C_{1.2}$}

$\mathbf{C}_{1.2}$ : Conector responsável por realizar a contagem do número total de genes existentes em cada lista de genes (arquivo) obtidos de acordo com uma condição experimental.

$\mathbf{E C}_{1.2}$ : Os dados de entrada do conector $\mathrm{C}_{1.2}$ consistem nos dados de saída do conector $\mathrm{C}_{1.1}$ $\left(\mathrm{SC}_{1.1}\right)$. Esses dados devem estar contidos em arquivos texto e devem representar vetores de identificadores de genes. Cada linha desses arquivos apresenta um identificador do gene que possui associação a uma sequência de bases nitrogenadas. Cada arquivo representa uma condição experimental na qual as sequências, associadas aos genes identificados, foram 
obtidas. A descrição desses dados é a mesma associada à saída do conector $\mathrm{C}_{1.1}$ (veja Tabela $6)$.

$\mathbf{S C}_{1.2}$ : Os dados de saída do conector $\mathrm{C}_{1.2}$ devem estar contidos em um arquivo texto e devem representar uma matriz na qual cada coluna deve apresentar uma condição experimental e uma linha de dados deve informar o número total de genes obtidos de acordo com essas condições. A Tabela 7 apresenta a descrição desses dados.

Tabela 7: Descrição dos dados de saída do conector $\mathbf{C}_{1.2}$

\begin{tabular}{|r|l|l|}
\hline Item de dado & \multicolumn{1}{|c|}{ Descrição semântica } & \multicolumn{1}{|c|}{ Sintaxe de representação } \\
\hline $\begin{array}{r}\text { Condição } \\
\text { experimental }\end{array}$ & $\begin{array}{l}\text { Dado que descreve a condiçăo experimental na qual } \\
\text { foram obtidas sequências que podem representar } \\
\text { genes, visando obter valores de expressão gênica }\end{array}$ & $\begin{array}{l}\text { Conjunto de valores do tipo String apresentados na } \\
\text { primeira linha da matriz de dados contido em um } \\
\text { arquivo texto delimitado por tabulações }\end{array}$ \\
\hline $\begin{array}{r}\text { Número total de } \\
\text { genes }\end{array}$ & $\begin{array}{l}\text { Dado que representa a quantidade total de genes que } \\
\text { foram obtidos de acordo com uma condição } \\
\text { experimental }\end{array}$ & $\begin{array}{l}\text { Conjunto de valores do tipo inteiro contidos na } \\
\text { segunda linha da matriz de dados contido em um } \\
\text { arquivo texto delimitado por tabulações }\end{array}$ \\
\hline
\end{tabular}

\section{C4.3. Descrição detalhada dos dados de interesse associados a $C_{1.3}$}

$\mathbf{C}_{1.3}$ : Conector responsável por realizar a transformação dos dados de entrada que consistem de uma lista de genes em uma matriz numérica.

EC $_{1.3}$ : Os dados de entrada do conector $\mathrm{C}_{1.3}$ consistem nos dados de saída do conector $\mathrm{C}_{1.1}$ $\left(\mathrm{SC}_{1.1}\right)$. Esses dados devem estar contidos em arquivos texto e devem representar vetores de identificadores de genes. Cada linha desses arquivos apresenta um identificador do gene que possui associação a uma sequência de bases nitrogenadas. Cada arquivo representa uma condição experimental na qual as sequências, associadas aos genes identificados, foram obtidas. A descrição desses dados é a mesma associada à saída do conector $\mathrm{C}_{1.1}$ (veja Tabela $6)$.

SC $_{\text {1.3 }}$ : Os dados de saída do conector $\mathrm{C}_{1.3}$ consistem nos dados consumidos pela ferramenta DMV através da funcionalidade $\mathrm{DMV}_{1}$ (importar dados de arquivos para filtragem dos dados). Esses dados devem estar contidos em arquivos texto com formato delimitado por tabulações e devem estar representados por uma matriz. Cada linha deve representar um identificador de gene e cada coluna um arquivo de dados obtido de acordo com uma condição experimental. Os valores da matriz devem associar um gene a uma condição e consistir de 
valores numéricos que representa o número de vezes que um gene foi obtido de acordo com uma condição. A Tabela 8 apresenta a descrição desses dados.

Tabela 8: Descrição dos dados de entrada relacionados à funcionalidade $\mathrm{DMV}_{1}$

\begin{tabular}{|r|l|l|}
\hline \multicolumn{1}{|c|}{ Item de dado } & \multicolumn{1}{|c|}{ Descrição textual } & Formato de representação \\
\hline $\begin{array}{r}\text { Identificador de um } \\
\text { gene }\end{array}$ & Dado que representa um identificador de um gene & $\begin{array}{l}\text { Conjunto de valores do tipo String apresentados na } \\
\text { primeira coluna da matriz de dados contidos em um } \\
\text { arquivo texto delimitado por tabulações }\end{array}$ \\
\hline $\begin{array}{r}\text { Condição } \\
\text { experimental }\end{array}$ & $\begin{array}{l}\text { Dado que descreve a condiçăo experimental na qual } \\
\text { foram obtidas sequências que podem representar } \\
\text { genes, visando obter valores de expressão gênica }\end{array}$ & $\begin{array}{l}\text { Conjunto de valores do tipo String apresentados na } \\
\text { primeira linha da matriz de dados contidos em um } \\
\text { arquivo texto delimitado por tabulações }\end{array}$ \\
\hline $\begin{array}{r}\text { Quantidade de } \\
\text { genes }\end{array}$ & $\begin{array}{l}\text { Dado que representa a quantidade de vezes que um } \\
\text { gene foi obtido de acordo com uma condiçăo } \\
\text { experimental }\end{array}$ & $\begin{array}{l}\text { Conjunto de valores do tipo inteiro contidos em } \\
\text { uma matriz de dados contidos em um arquivo texto } \\
\text { delimitado por tabulações }\end{array}$ \\
\hline
\end{tabular}

\section{C5. Modelagem conceitual dos dados de interesse}

A modelagem conceitual foi realizada separadamente para cada conector simples, $\mathrm{C}_{1.1}$, $\mathrm{C}_{1.2}$ e $_{1.3}$, que forma $\mathrm{C}_{1}$.

\section{C5.1. Modelagem conceitual dos dados de interesse associados a $C_{1.1}$}

A Figura 34 ilustra a modelagem conceitual dos dados de interesse associados à entrada do conector $\mathrm{C}_{1.1}\left(\mathrm{EC}_{1.1}\right)$. A partir da descrição detalhada dos dados de interesse é possível identificar uma sequência de bases nitrogenadas em cada linha dos arquivos de entrada. Essas sequências foram obtidas de acordo com diferentes condições experimentais e podem aparecer diversas vezes em um mesmo arquivo. Cada arquivo representa uma condição experimental diferente.

Dessa forma os seguintes conceitos foram identificados: Sequencia_Bases, que representa uma sequência de bases nitrogenadas ordenadas e Condicao_Experimental, que representa a condição experimental através de cada arquivo que contém as sequências. Dessa forma cada arquivo representa o conceito Condicao_Experimental e contém um conjunto de sequências, representantes do conceito Sequencia_Bases. Os arquivos são utilizados como entrada para o conector $\mathrm{C}_{1.1}$, responsável por realizar o serviço de identificação de genes. 


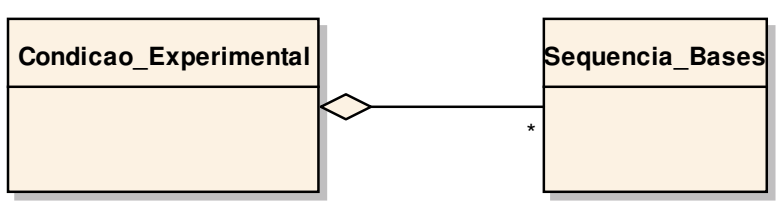

Figura 34: Modelagem conceitual associada à entrada do conector $C_{1.1}$ (segundo estudo de caso)

A Figura 35 ilustra a modelagem conceitual dos dados associados à saída do conector $\mathrm{C}_{1.1}\left(\mathrm{SC}_{1.1}\right)$. Esse conector realiza o serviço de identificação dos genes, utilizando sequências de bases nitrogenadas como entrada e gera como saída vetores de identificadores de genes. Nesta situação os seguintes conceitos foram identificados: Gene, que representa um gene cujo valor de expressão gênica é mensurado e Condicao_Experimental, que representa a condição experimental através de cada arquivo que contém os genes.

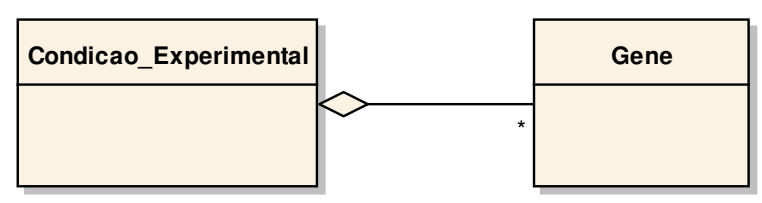

Figura 35: Modelagem conceitual associada à saída do conector $\mathrm{C}_{1.1}$ (segundo estudo de caso)

\section{C5.2. Modelagem conceitual dos dados de interesse associados a $C_{1.2}$}

A modelagem conceitual dos dados associados à entrada do conector $\mathrm{C}_{1.2}\left(\mathrm{EC}_{1.2}\right)$ é idêntica à modelagem conceitual dos dados associados à saída do conector $\mathrm{C}_{1.1}\left(\mathrm{SC}_{1.1}\right)$ (veja Figura 35). Esses dados consistem de vetores de genes contidos em arquivos que representam condições experimentais. Gene e Condicao_Experimental são os conceitos identificados.

A Figura 36 ilustra a modelagem conceitual dos dados associados à saída do conector $\mathrm{C}_{1.2}\left(\mathrm{SC}_{1.2}\right)$. Esses dados representam o resultado gerado pelo conector responsável pela contagem do número total de genes obtidos de acordo com cada uma das condições experimentais. Cada arquivo de dados representa uma condição experimental. Nesta situação os seguintes conceitos foram identificados: Condicao_Experimental, que representa a condição experimental em que os genes são submetidos para a medição da expressão gênica; Total_Genes, que representa o número total de genes identificados de acordo com uma condição experimental. 


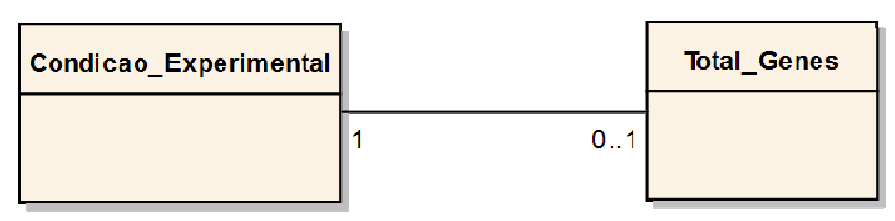

Figura 36: Modelagem conceitual associada à saída do conector $C_{1.2}$

\section{C5.3. Modelagem conceitual dos dados de interesse associados a $C_{1.3}$}

A modelagem conceitual dos dados associados à entrada do conector $\mathrm{C}_{1.3}\left(\mathrm{EC}_{1.3}\right)$ é idêntica à modelagem conceitual dos dados associados à saída do conector $\mathrm{C}_{1.1}\left(\mathrm{SC}_{1.1}\right)$ (veja Figura 35). Esses dados consistem de vetores de genes contidos em arquivos que representam condições experimentais. Gene e Condicao_Experimental são os conceitos identificados.

A Figura 37 ilustra a modelagem conceitual dos dados associados à saída do conector $\mathrm{C}_{1.3}$. A partir da descrição detalhada dos dados de interesse é possível identificar genes e condições experimentais. Para cada associação de um gene e uma condição experimental existe um número associado que expressa a quantidade de vezes que um gene foi obtido de acordo com uma condição.

Os seguintes conceitos foram identificados: Gene, que representa um gene cujo valor de expressão gênica foi mensurado; Condicao_Experimental, que representa a condição experimental em que os genes são submetidos para a medição da expressão gênica; Quantidade_Gene, que representa um valor que quantifica o número de vezes que um determinado gene é expresso em uma dada condição experimental. Quantidade_Gene foi modelada como uma classe de associação definida entre Condicao_Experimental e Gene.

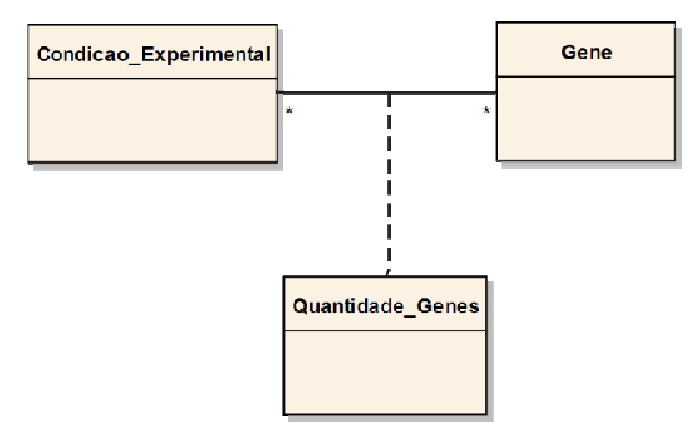

Figura 37: Modelagem conceitual associada à saída do conector $\mathrm{C}_{1.3}$ (segundo estudo de caso) 


\section{C6. Mapeamento para ontologia de referência}

O mapeamento para ontologia de referência foi realizado separadamente para cada conector simples, $\mathrm{C}_{1.1}, \mathrm{C}_{1.2}$ e $\mathrm{C}_{1.3}$, que forma $\mathrm{C}_{1}$.

\section{C6.1. Mapeamento para ontologia de referência associado ao conector $C_{1.1}$}

A Tabela 9 apresenta o mapeamento entre os conceitos associados à entrada e à saída do conector $\mathrm{C}_{1.1}$ aos conceitos da ontologia de referência.

Tabela 9: Mapeamento dos conceitos associados à entrada e à saída do conector $\mathrm{C}_{1.1}$ (segundo estudo de caso) aos conceitos da ontologia de referência

\begin{tabular}{|c|c|c|}
\hline $\begin{array}{c}\text { Conceito entrada } \\
\text { conector }\end{array}$ & $\begin{array}{c}\text { Conceito ontologia } \\
\text { referência }\end{array}$ & $\begin{array}{c}\text { Conceito saída } \\
\text { conector }\end{array}$ \\
\hline Sequencia_Bases & Base_Sequence & \\
\hline Condicao_Experimental & Experimental_Condition & Condicao_Experimental \\
\hline & Gene & Gene \\
\hline
\end{tabular}

Neste mapeamento os conceitos estão corretamente associados a seus respectivos conceitos da ontologia de referência. Existem conceitos que não estão associados a seus respectivos dados de entrada ou saída do conector. Essa falta de associação é justificada pela transformação dos dados de entrada do conector que representam Sequencia_Bases em Gene. O conector responsável por essa transformação realiza o serviço de identificação do gene que associa instâncias de Sequencia_Bases a Genes. Dessa forma, Gene pode ser obtido a partir de um consulta a um banco de dados BLAST que relaciona sequências de bases a genes conhecidos. Assim, Gene (conceito de saída do conector) pode ser obtido a partir de Sequencia_Bases (conceito de entrada do conector).

A Tabela 10 apresenta o mapeamento revisado dos conceitos associados à entrada e à saída do conector aos conceitos da ontologia. Para essa situação não foi necessário inserir novos conceitos na ontologia de referência, mas é necessária uma transformação dos dados para tornar possível a associação entre conceitos distintos associados à entrada e à saída do conector e assim possibilitar um mapeamento completo de todos os conceitos. 
Tabela 10: Mapeamento revisado dos conceitos associados à entrada e à saída do conector $\mathrm{C}_{1.1}$ (segundo estudo de caso) aos conceitos da ontologia de referência

\begin{tabular}{|c|c|c|}
\hline $\begin{array}{c}\text { Conceito entrada } \\
\text { conector }\end{array}$ & $\begin{array}{c}\text { Conceito ontologia } \\
\text { referência }\end{array}$ & $\begin{array}{c}\text { Conceito saída } \\
\text { conector }\end{array}$ \\
\hline Sequencia_Bases & Base_Sequence/Gene & Gene \\
\hline Condicao_Experimental & Experimental_Condition & Condicao_Experimental \\
\hline
\end{tabular}

\section{C6.2. Mapeamento para ontologia de referência associado ao conector $C_{1.2}$}

A Tabela 11 apresenta o mapeamento entre os conceitos associados à entrada e à saída do conector $\mathrm{C}_{1.2}$ aos conceitos da ontologia de referência.

Tabela 11: Mapeamento dos conceitos associados à entrada e à saída do conector $\mathrm{C}_{1.2}$ (segundo estudo de caso) aos conceitos da ontologia de referência

\begin{tabular}{|c|c|c|}
\hline $\begin{array}{c}\text { Conceito entrada } \\
\text { conector }\end{array}$ & $\begin{array}{c}\text { Conceito ontologia } \\
\text { referência }\end{array}$ & $\begin{array}{c}\text { Conceito saída } \\
\text { conector }\end{array}$ \\
\hline Gene & Gene & Condicao_Experimental \\
\hline Condicao_Experimental & Experimental_Condition & Total_Genes \\
\hline & & \\
\hline
\end{tabular}

Neste mapeamento existe um conceito associado à saída do conector que não possui equivalência na ontologia de referência. Além disso, existem situações em que conceitos não estão associados a seus respectivos conceitos de entrada ou saída associados ao conector. A falta de associação entre os conceitos de entrada e saída é justificada pela transformação dos dados de entrada do conector realizada pelo conector $\mathrm{C}_{1.2}$, responsável por realizar a contagem total do número de genes obtidos de acordo com cada condição experimental.

O conceito de entrada Gene não está associado diretamente a nenhum conceito de saída, mas é utilizado para obter Total_Genes. O conceito de saída Total_Genes pode ser obtido a partir da contagem do número de ocorrências de Gene em cada arquivo que representa uma Condicao_Experimental.

Gene e Condicao_Experimental possuem conceitos equivalentes na ontologia de referência, contudo Total_Genes não possui. Dessa forma, a inserção desse conceito na ontologia de referência é necessária, pois representa uma informação importante associada a Condicao_Experimental. Para isso foi realizada uma revisão da ontologia de forma a 
viabilizar a adição desse conceito. A Figura 38 ilustra a parte da ontologia modificada com a inserção de um novo conceito Total_Sampled_Gene_Amount.

Uma condição experimental (Experimental_Condition) representa condições sobre os quais experimentos com genes são submetidos para realizar a medição da expressão gênica. A condição experimental (Experimental_Condition) afeta a expressão gênica (Gene_Expression) e pode possuir uma quantidade de genes identificados (Total_Sampled_Gene_Amount) de acordo com essa condição. Dessa forma, deve existir uma quantidade (Total_Sampled_Gene_Amount) associada a uma condição experimental (Experimental_ Condition) caso a abordagem para obtenção de dados de expressão gênica seja baseada em sequência. Caso contrário, essa quantidade não precisa ser informada.

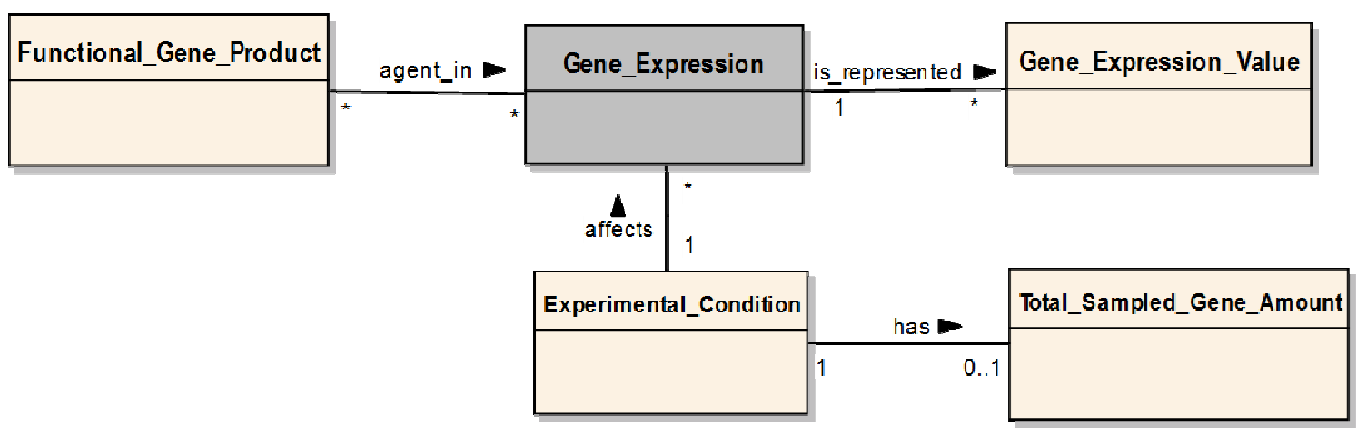

Figura 38: Adição do conceito Total_Sampled_Gene_Amount na ontologia de referência

A .

Tabela 12 apresenta a adequação do mapeamento realizada após a revisão da ontologia. O conceito de entrada Gene não está diretamente associado a nenhum conceito de saída, contudo ele é utilizado para obter Total_Genes através da contagem do número de ocorrências de Gene em uma Condicao_Experimental. O conceito de saída Total_Genes foi mapeado para o conceito inserido na ontologia de referência Total_Sampled_Gene_Amount.

Tabela 12: Mapeamento revisado dos conceitos associados à entrada e à saída do conector $\mathrm{C}_{1.2}$ aos conceitos da ontologia de referência 


\begin{tabular}{|c|c|c|}
\hline $\begin{array}{c}\text { Conceito entrada } \\
\text { conector }\end{array}$ & $\begin{array}{c}\text { Conceito ontologia } \\
\text { referência }\end{array}$ & $\begin{array}{c}\text { Conceito saída } \\
\text { conector }\end{array}$ \\
\hline Gene & Gene & - \\
\hline Condicao_Experimental & Experimental_Condition & Condicao_Experimental \\
\hline$($ Gene $)$ & $\begin{array}{c}\text { Total_Sampled_Gene_Am } \\
\text { ount }\end{array}$ & Total_Genes \\
\hline
\end{tabular}

\section{C6.3. Mapeamento para ontologia de referência associado ao conector $C_{1.3}$}

A Tabela 13 apresenta o mapeamento entre os conceitos associados à entrada e à saída do conector $\mathrm{C}_{1.3}$ aos conceitos da ontologia de referência.

Tabela 13: Mapeamento dos conceitos associados à entrada e à saída do conector $\mathrm{C}_{1.3}$ (segundo estudo de caso) aos conceitos da ontologia de referência

\begin{tabular}{|c|c|c|}
\hline $\begin{array}{c}\text { Conceito entrada } \\
\text { conector }\end{array}$ & $\begin{array}{c}\text { Conceito ontologia } \\
\text { referência }\end{array}$ & $\begin{array}{c}\text { Conceito saída } \\
\text { conector }\end{array}$ \\
\hline Gene & Gene & Gene \\
\hline Condicao_Experimental & Experimental_Condition & Condicao_Experimental \\
\hline & & Quantidade_Genes \\
\hline
\end{tabular}

Neste mapeamento existe um conceito associado à saída do conector que não possui equivalência na ontologia de referência. Além disso, esse conceito não está associado a seu respectivo conceito de entrada associado ao conector. A falta de associação entre os conceitos de entrada e saída é justificada pela transformação dos dados de entrada em uma matriz de valores numéricos que representam Quantidade_Genes realizada pelo conector $\mathrm{C}_{1.2}$. Essa transformação consiste na contagem do número de vezes que um Gene foi obtido de acordo com uma Condicao_Experimental. Dessa forma Quantidade_Genes pode ser obtido a partir de Genes, utilizado como entrada para o conector.

O conceito de saída Quantidade_Genes não possui equivalência na ontologia de referência. Para isso foi realizada uma revisão da mesma de forma a viabilizar a adição desse conceito. A Figura 39 ilustra a parte da ontologia modificada com a inserção de novos conceitos para dar suporte à inserção do conceito Sampled_Gene_Amount.

Uma condição experimental (Experimental_Condition) representa condições sobre as quais experimentos com genes são submetidos para realizar a medição da expressão gênica. 
Sampled_Gene_Amount foi modelado como uma classe de associação que representa o número de vezes que um gene (Gene) foi identificado em uma condição experimental (Experimental_Condition). O valor de expressão gênica baseado pela contagem (Count_Based_Value) é obtido através da normalização que consiste na razão entre a quantidade de vezes que um gene foi obtido de acordo com uma condição experimental (Sampled_Gene_Amount) dividido pelo número total de genes expressos (Total_Sampled_Gene_Amount) obtidos de acordo com a mesma condição.

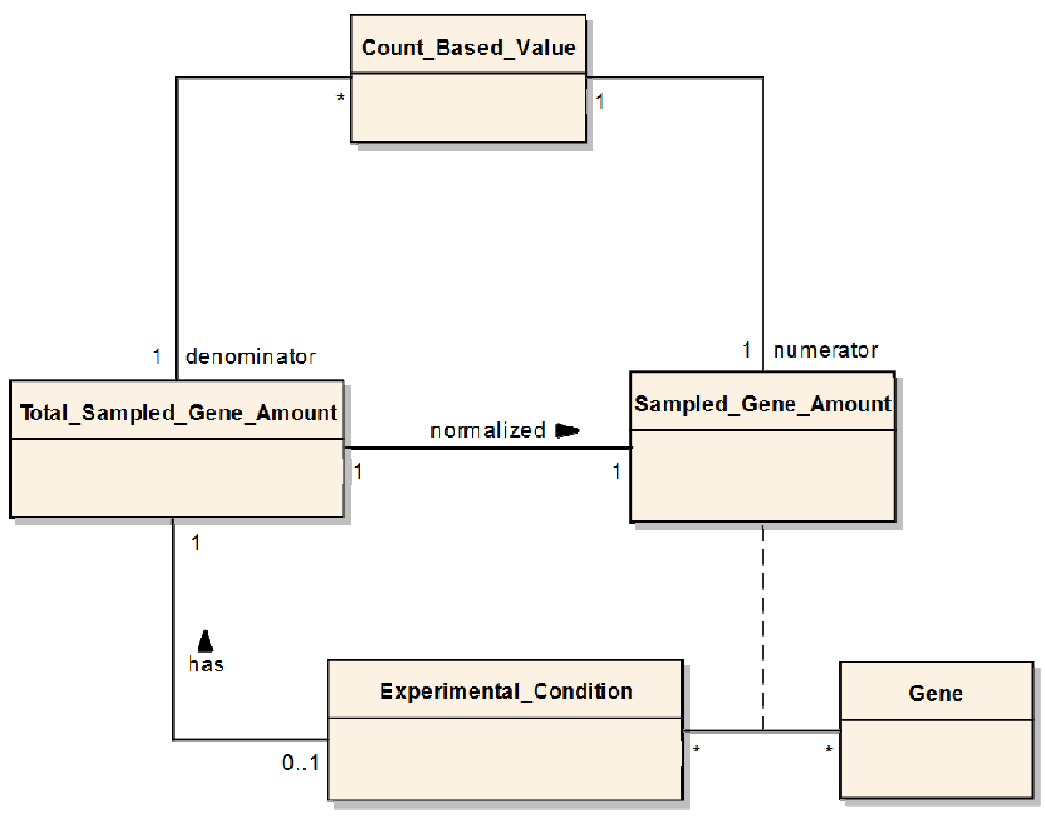

Figura 39: Ontologia de referência revisada

A Tabela 14 apresenta a adequação do mapeamento realizada após a revisão da ontologia. O conceito de saída Quantidade_Genes foi mapeado para o conceito inserido na ontologia de referência Sampled_Gene_Amount e foi obtido através da contagem do número de ocorrências de um Gene em uma Condicao_Experimental. 
Tabela 14: Mapeamento revisado dos conceitos associados à entrada e à saída do conector $\mathrm{C}_{1.3}$ (segundo estudo de caso) aos conceitos da ontologia de referência

\begin{tabular}{|c|c|c|}
\hline $\begin{array}{c}\text { Conceito entrada } \\
\text { conector }\end{array}$ & $\begin{array}{c}\text { Conceito ontologia } \\
\text { referência }\end{array}$ & $\begin{array}{c}\text { Conceito saída } \\
\text { conector }\end{array}$ \\
\hline Gene & Gene & Gene \\
\hline Condicao_Experimental & Experimental_Condition & Condicao_Experimental \\
\hline $\begin{array}{c}\text { (Gene e } \\
\text { Condicao_Experimental) }\end{array}$ & Sampled_Gene_Amount & Quantidade_Genes \\
\hline
\end{tabular}

\section{C7. Adequação dos dados de interesse}

As adequações sintáticas e semânticas que devem ser realizadas foram definidas separadamente para cada conector simples, $\mathrm{C}_{1.1}, \mathrm{C}_{1.2}$ e $\mathrm{C}_{1.3}$, que forma $\mathrm{C}_{1}$.

\section{C7.1. Adequação dos dados de interesse associados ao conector $C_{1.1}$}

Os dados de entrada consistem de arquivos extensão sra. Cada arquivo contém uma lista de sequência de bases nitrogenadas, resultado da execução de uma abordagem baseada em sequência para medição da expressão gênica. Contudo nesses arquivos existem outras informações não relevantes para este cenário de integração. Apenas a lista de sequências de bases nitrogenadas representa os dados de interesse. Dessa forma é necessário extrair apenas os dados de interesse desses arquivos com extensão sra. A adequação sintática consiste de duas etapas. A primeira consiste na conversão dos arquivos sra para o formato FASTA. Assim, $\mathrm{C}_{1.1}$ é responsável por extrair apenas a lista de sequências de bases nitrogenadas de cada arquivo e salvar essa lista em um arquivo FASTA. Cada sequência deve estar separada por uma quebra de linha. A segunda etapa consiste na conversão dos dados contidos nos arquivos FASTA em listas de String.

A adequação semântica consiste em transformar as listas de String em listas de sequências de bases nitrogenadas. Posteriormente deve ser feita a transformação dessas listas de sequências em listas de genes. Para isso é necessário realizar a substituição dos valores das sequências que representam genes conhecidos pelos seus respectivos identificadores de genes através de uma consulta a um banco de dados BLAST para encontrar associações entre as sequências a um gene identificado no banco. Caso exista, o valor do identificador do gene deve substituir o valor da sequência. 


\section{C7.2. Adequação dos dados de interesse associados ao conector $C_{1.2}$}

A adequação sintática consiste na conversão dos dados extraídos de um arquivo texto em uma lista de String. A adequação semântica consiste em transformar as listas de String em listas de sequências de bases nitrogenadas e posteriormente realizar a contagem do número de genes existentes em cada arquivo que representa uma condição experimental. Esses dados devem ser armazenados em um novo arquivo que não será utilizado pela ferramenta DMV, mas será utilizado posteriormente pelo conector $\mathrm{C}_{2}$ deste mesmo estudo de caso.

\section{C7.3. Adequação dos dados de interesse associados ao conector $C_{1.3}$}

A adequação sintática consiste na conversão dos dados extraídos de um arquivo texto em uma lista de String. A adequação semântica consiste em transformar as listas de String em listas de sequências de bases nitrogenadas e posteriormente realizar a contagem do número de ocorrências de cada gene em cada arquivo. Esses números devem ser informados em uma matriz que apresenta um gene em cada linha e um arquivo representando uma condição experimental em cada coluna. Os valores dessa matriz devem informar o número de vezes que cada gene foi obtido em cada condição experimental.

\section{C8. Identificação de políticas de acesso e ativação}

A ferramenta DMV disponibiliza acesso local às suas funcionalidades e pode ser instalada em qualquer diretório. Não existem restrições de acesso a essa ferramenta, o usuário define as configurações básicas de instalação dessa ferramenta. A transferência de controle pode ser manual ou automática a partir da execução do conector. Contudo, essa ferramenta não permite sua inicialização com os dados já carregados na memória e armazenados em alguma variável. Assim, o usuário deve requisitar a importação de dados manualmente.

\section{C9. Implementação do conector}

A Figura 40 ilustra o diagrama de classes UML dos três conectores simples identificados. Todas as classes foram implementadas utilizando a linguagem de programação Java. 


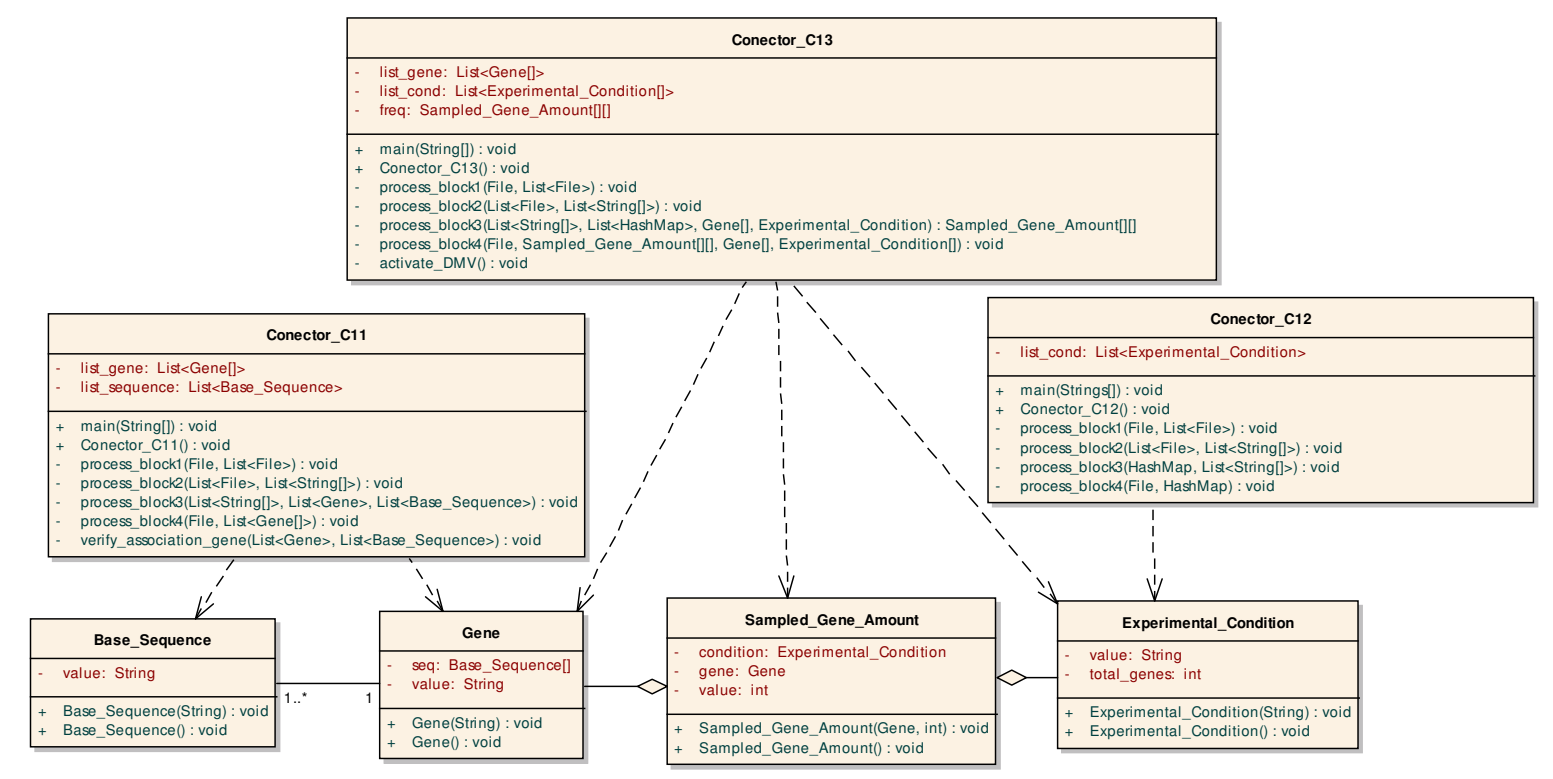

Figura 40: Diagrama de classes dos conectores simples

As classes Base_Sequence, Gene, Experimental_Condition e Sampled_Gene_Amount foram criadas a partir dos conceitos identificados nos modelos conceituais. Base_Sequence é uma classe para representação de sequências de bases nitrogenadas que são obtidas a partir da execução de uma abordagem baseada em sequência para medição da expressão gênica. Gene é uma classe para representação de genes e, neste caso armazena o identificador do gene. Essa classe possui associada uma ou mais sequências de bases nitrogenadas. Experimental_Condition é uma classe para representação de condições experimentais nas quais os genes são submetidos para medição da expressão gênica. Sampled_Gene_Amount é uma classe de associação para representação da quantidade de vezes que cada gene identificado foi obtido de acordo com cada condição experimental.

As classes Conector_C11, Conector_C12 e Conector_C13 representam os conectores simples $\mathrm{C}_{1.1}, \mathrm{C}_{1.2}$ e $\mathrm{C}_{1.3}$, respectivamente. Cada conector simples foi modelado e implementado como uma aplicação Java. Dessa forma, cada conector pode ser (re)utilizado e executado independentemente dos demais conectores. A classe Conector_C1 (não representada no diagrama da Figura 40) representa o conector composto C1. Esta classe é responsável pela composição e execução individual de cada um dos conectores simples.

Os conectores $\mathrm{C}_{1.1}, \mathrm{C}_{1.2}$ e $\mathrm{C}_{1.3}$ são executados sequencialmente e nesta ordem. Somente após o término da execução de um conector, outro conector é executado. Cada conector é executado como um processo independente e dessa forma possui uma thread de controle 
responsável pela execução de seus blocos funcionais, implementados como métodos de suas respectivas classes. Estes blocos também são executados de forma sequencial, de modo que um bloco é executado somente após o término da execução do bloco anterior.

$\mathrm{O}$ primeiro conector, $\mathrm{C}_{1.1}$, é responsável por realizar a identificação de genes a partir de dados que representam sequências de bases nitrogenadas. O método main recebe como parâmetros o identificador do diretório que contém os arquivos com os dados de entrada e o identificador do diretório onde serão armazenados os dados de saída desse conector. Os dados de entrada consistem de arquivos cujos dados representam sequências de bases nitrogenadas e estão contidos em um diretório informado pelo usuário. Os dados de saída consistem de arquivos cujos dados representam genes. Os atributos dessa classe consistem de uma lista de vetores de sequências de bases (Base_Sequence) e uma lista de vetores de genes (Gene).

O método process_block1 realiza o processamento inicial dos dados através do preenchimento da lista com os arquivos que estão contidos no diretório. Esse método recebe como parâmetro um identificador de arquivo (File) que identifica o diretório informado pelo usuário e uma lista de arquivos (File) com os arquivos de entrada contidos nesse diretório. $\mathrm{O}$ método process_block2 realiza a transformação sintática dos dados contidos nesses arquivos (veja seção C7.1). Esse método recebe como parâmetros uma lista de arquivos de entrada (File) e uma lista de vetores String para armazenar os dados contidos nos arquivos de entrada preenchida nesse método. O método process_block3 realiza a transformação semântica dos dados (veja seção C7.1). Esse método recebe como parâmetros uma lista de vetores String que contém os dados dos arquivos de entrada transformados sintaticamente, uma lista de vetores para armazenar sequências de bases nitrogenadas contidas na primeira lista e uma lista de vetores de genes para armazenar listas de gene associadas às listas de sequências. As duas últimas listas são preenchidas nesse método, o qual utiliza o método auxiliar verify_association_gene para realizar a associação entre genes e sequências de bases nitrogenadas. O método process_block4 realiza o processamento dos dados de saída do conector. Esse método recebe como parâmetros uma lista de vetores de genes gerados no método process_block3 que representam os dados de saída, e um identificador de arquivo (File) representando o diretório que irá conter esses dados. De forma padrão, esse diretório está contido no diretório dos dados de entrada. 
$\mathrm{O}$ segundo conector, $\mathrm{C}_{1.2}$, é responsável por realizar a contagem do número total de genes que estão contidos em cada arquivo. O método main recebe como parâmetros o identificador do diretório que contém os arquivos com os dados de entrada e o identificador do diretório onde serão armazenados os dados de saída desse conector. Os dados de entrada desse conector consistem de arquivos cujos dados representam genes e estão contidos no diretório informado pelo usuário. Os dados de saída consistem de um arquivo que contém o número total de genes existente em cada arquivo de entrada. $\mathrm{O}$ atributo dessa classe consiste de uma lista de condições experimentais.

O método process_block1 realiza o processamento inicial dos dados. Esse método recebe como parâmetro um objeto do tipo File que contém o diretório dos arquivos que serão utilizados como entrada e uma lista de arquivos (File) a ser preenchida nesse método com os identificadores dos arquivos contidos no diretório especificado. O método process_block2 recebe como parâmetro a lista de arquivos (File) de entrada e uma lista de vetores de String para armazenar os dados contidos nos arquivos de entrada. Esse método realiza a transformação sintática dos dados contidos nesses arquivos (veja seção C7.2). O método process_block3 recebe como parâmetro uma lista de vetores de String que armazena os dados dos arquivos de entrada arquivos transformados sintaticamente e uma tabela hash para armazenar o número de genes identificados em cada condição experimental. Esse método realiza a transformação semântica dos dados (veja seção C7.2). O método process_block4 é responsável pelo processamento dos dados de saída do conector. Os parâmetros desse método consistem de uma tabela hash que contém os dados que serão salvos em um arquivo e de um identificador de arquivo (File) representando o diretório em que esse arquivo será criado. Novamente, de forma padrão esse diretório está contido no diretório dos dados de entrada.

$\mathrm{O}$ último conector, $\mathrm{C}_{1.3}$, é responsável por realizar a transformação dos dados em matriz numérica. $\mathrm{O}$ método main recebe como parâmetros o identificador do diretório que contém os arquivos com os dados de entrada, o identificador do diretório onde serão armazenados os dados de saída desse conector e o identificador do arquivo utilizado na ativação automática da ferramenta, se houver. Os dados de entrada desse conector consistem de arquivos cujos dados representam genes e estão contidos no diretório informado pelo usuário como parâmetro do método main. Os dados de saída consistem de um arquivo que contém o número de vezes que cada gene foi identificado em cada arquivo de entrada (condição experimental). Os atributos dessa classe consistem de uma lista de vetores de 
genes (Gene), um vetor de condições experimentais (Experimental_Condition) e uma matriz do número de vezes que cada gene foi obtido em uma amostra (Sampled_Gene_Amount).

O método process_block1 realiza o processamento inicial dos dados e recebe como parâmetro um objeto File que identifica o diretório dos arquivos que serão utilizados como entrada e uma lista de objetos (File) a ser preenchida nesse método com os identificadores dos arquivos contidos no diretório especificado. O método process_block2 recebe como parâmetro a lista de arquivos (File) de entrada e uma lista de vetores String para armazenar os dados contidos nos arquivos de entrada preenchidos nesse método. Esse método realiza a transformação sintática dos dados contidos nesses arquivos (veja seção C7.3). O método process_block3 recebe como parâmetro uma lista de vetores String que armazena os dados dos arquivos de entrada transformados sintaticamente, uma lista de tabelas hash para armazenar o resultado da contagem do número de vezes que cada gene é obtido de acordo com cada condição experimental, um vetor de genes e um vetor de condições experimentais. Esse método realiza a transformação semântica dos dados (veja seção C7.3) e retorna uma matriz do número de vezes que cada gene foi obtido em uma amostra (Sampled_Gene_Amount). O método process_block4 é responsável pelo processamento dos dados de saída do conector e pela ativação automática da ferramenta DMV. Os parâmetros desse método consistem da matriz do número de vezes que cada gene foi obtido em uma amostra (Sampled_Gene_Amount), um vetor de genes (Gene), um vetor de condições experimentais (Experimental_Condition), todos contendo dados que serão salvos em um arquivo, e dois objetos do tipo File, um para identificar o diretório onde esse arquivo será criado e outro para identificar o arquivo responsável pela ativação automática da ferramenta DMV. De forma padrão esse diretório está contido no diretório dos dados de entrada. A ativação automática da ferramenta DMV é realizada através da execução do arquivo jnlp como um processo para inicialização da mesma. Essa ativação é implementada através da função activate_DMV. Assim como a ferramenta $\mathrm{TMeV}$, DMV não possibilita carregar os dados na inicialização da ferramenta. 


\section{APÊNDICE D - Desenvolvimento do conector responsável pela integração das ferramentas DMV e TMEV-Segundo estudo de caso.}

$\mathrm{O}$ conector $\mathrm{C}_{2}$ é o responsável pela integração das ferramentas DMV e TIGR Microarray expression Viewer (TMeV). A ferramenta DMV foi desenvolvida na linguagem de programação Java e possibilita, em geral, carregar, exibir, selecionar e explorar dados numéricos gerados por experimentos de larga escala. TMeV é uma ferramenta desktop que realiza o processamento de dados genômicos através de uma variedade de algoritmos para clusterização, visualização, classificação e análises estatísticas.

\section{D1. Identificação das principais funcionalidades das ferramentas envolvidas}

\section{Listagem funcional da ferramenta DMV:}

A listagem funcional está apresentada na seção A1 do Apêndice A.

Listagem funcional da ferramenta TMeV:

A listagem funcional está apresentada na seção B1 do Apêndice B.

\section{D2. Descrição inicial do cenário de integração}

Subconjunto de funcionalidades diretamente relacionadas ao cenário de integração:

DMV 1 : Importar dados. Esses dados devem estar contidos em arquivo de texto com formato delimitado por tabulações ou em um repositório de dados. Os dados importados são carregados pela ferramenta.

$\mathbf{D M V}$ : Exibir dados em uma planilha eletrônica.

DMV $_{6}$ : Selecionar subconjunto dos dados exibidos a partir de algum critério de seleção. Por exemplo, selecionar dados cujos valores estão acima de um limiar determinado pelo usuário.

DMV 13: Exportar dados selecionados em arquivos. Esses dados são exportados em um arquivo de texto com formato delimitado por tabulações.

TMEV $_{1}$ : Importar dados de arquivos em formatos específicos. Esses arquivos devem estar contidos em arquivo cujo formato é aceito por esta ferramenta e são carregados pela mesma.

TMEV $_{4}$ : Exibir dados. Esses dados podem ser representados por único array ou por vários arrays que constituem um conjunto de dados de expressão. Os dados são exibidos em uma 
interface de visualização. Em geral, essa interface exibe um gráfico que representa um mapa de expressão linear ou uma matriz de distância dos genes.

TMEV 6: Realizar a clusterização dos dados e exibir o resultado. Os algoritmos K-means, hierárquico, teste-T, análise de significância, análise de genes podem ser utilizados na clusterização.

O cenário envolve a integração de serviços providos pela ferramenta Data Matrix View (DMV) e a ferramenta TIGR Microarray expression Viewer (TMeV). A ferramenta DMV é utilizada para selecionar, a partir de algum critério, um subconjunto de dados. TMeV é utilizado para realizar a clusterização dos dados.

Inicialmente o usuário da ferramenta DMV importa dados contidos em arquivo texto (formato delimitado por tabulações). Esses dados são carregados em uma matriz e disponibilizados para uso $\left(\mathbf{D M V} \mathbf{V}_{\mathbf{1}}\right)$. Com os dados carregados, DMV exibe os mesmos em uma planilha eletrônica $\left(\mathbf{D M V} \mathbf{V}_{\mathbf{2}}\right)$. O usuário escolhe um valor de threshold (limiar) como critério de seleção de um subconjunto de dados. Apenas os dados que possuem valores acima desse limiar são selecionados $\left(\mathbf{D M V}_{\mathbf{6}}\right)$. O usuário então exporta o subconjunto de dados selecionados em um arquivo texto com formato delimitado por tabulações ( $\mathbf{D M V} \mathbf{1 3})$.

Após a filtragem de dados, o arquivo gerado por DMV deve ser processado (transformado e validado) para que possa ser aceito pela ferramenta $\mathrm{TMeV}$ para realizar a clusterização. Sugere-se que a clusterização dos dados seja aplicada em dados normalizados visando minimizar a interferência de erros associados a ruídos ou qualquer outro fator externo. $\mathrm{O}$ usuário da ferramenta $\mathrm{TMeV}$ importa os dados filtrados pela ferramenta DMV e transformados através da normalização. Esses dados são carregados em uma matriz e disponibilizados para uso (TMEV $)_{1}$. Com os dados carregados, TMeV exibe os mesmos em uma interface de visualização $\left(\mathbf{T} \mathbf{M E V} \mathbf{V}_{4}\right)$. Finalmente o usuário escolhe um algoritmo para clusterização dos dados (exemplo: algoritmo K-means) $\left(\mathbf{T M E V}_{\mathbf{6}}\right.$ ) e o resultado dessa atividade é exibido $\left(\mathbf{T M E V}_{4}\right)$.

\section{D3. Descrição detalhada do cenário de integração}

A Figura 41 ilustra o diagrama de atividades elaborado a partir da descrição inicial do cenário de integração. As atividades "Importação de dados contidos em arquivo”, "Exibição dos dados em planilha eletrônica", "Seleção de dados a partir de um threshold" e 
"Exportação dos dados selecionados em arquivo" são realizadas pelo DMV. A atividade "Normalização dos dados" é realizada pelo conector, enquanto que as atividades "Importação de dados de expressão gênica contidos em arquivo”, "Exibição dos dados importados", "Clusterização dos dados utilizando algoritmo K-means" e "Exibição do resultado da clusterização" são realizadas pela ferramenta $\mathrm{TMeV}$.

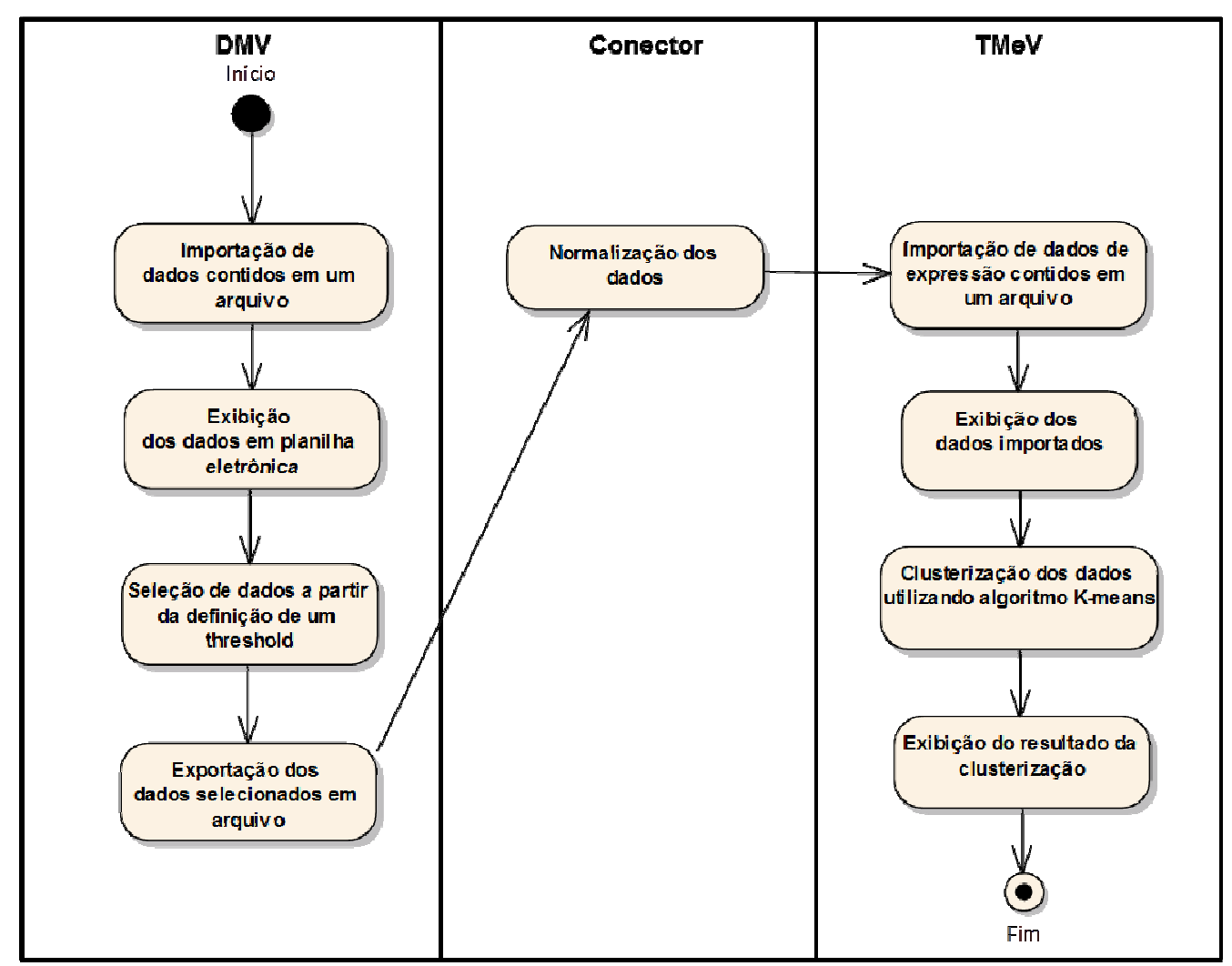

Figura 41: Diagrama de atividades relacionado ao desenvolvimento do conector $\mathrm{C}_{2}$ (segundo estudo de caso)

A Figura 42 ilustra os casos de uso derivados do diagrama de atividades. Os casos de uso "Importar e carregar dados em uma matriz", "Exibir matriz de dados", "Selecionar dados” e "Exportar dados selecionados" estão associados à ferramenta DMV. Os casos de uso "Processar dados" e "Normalizar dados" estão associados ao conector, enquanto que os casos de uso "Importar e carregar valores de expressão gênica”, "Exibir dados", "Realizar clusterização dos dados utilizando algoritmo K-means” e “Exibir dados clusterizados” estão associados à ferramenta $\mathrm{TMeV}$. Os casos de uso de interesse foram identificados em cinza. A descrição detalhada desses casos de uso é apresentada na seção D3.1. 


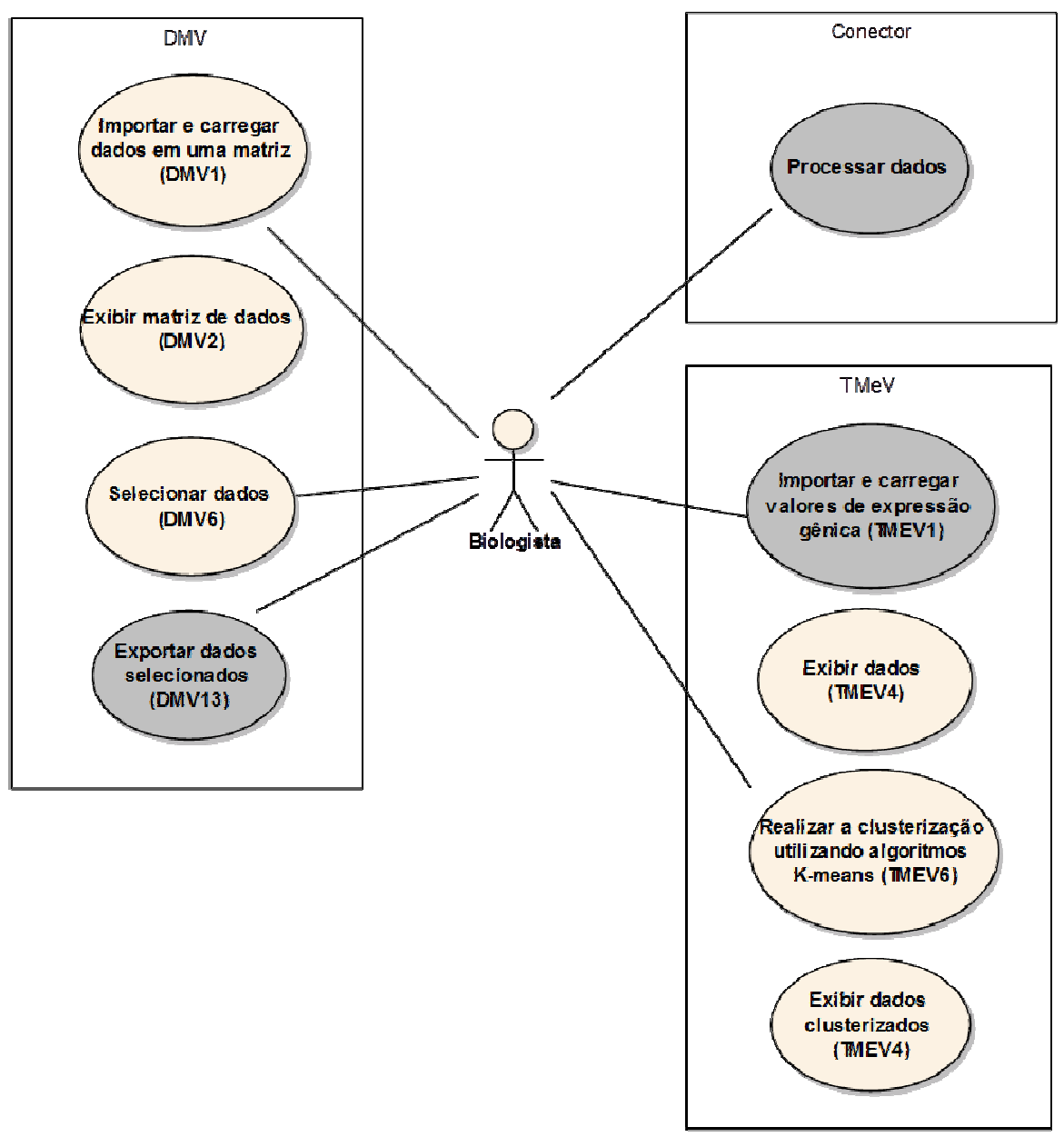

Figura 42: Diagrama de casos de uso relacionado ao desenvolvimento do conector $\mathrm{C}_{2}$ (segundo estudo de caso)

\section{D3.1. Casos de uso expandido}

\begin{tabular}{|l|l|}
\hline Caso de Uso & Exportar dados selecionados (DMV) \\
\hline Atores & Biologista (iniciador) \\
\hline Finalidade & $\begin{array}{l}\text { Exportar dados de interesse, selecionados a partir de algum critério, em } \\
\text { um arquivo texto com formato delimitado por tabulações. }\end{array}$ \\
\hline Visão Geral & $\begin{array}{l}\text { Após a seleção de dados de interesse, o biologista opta por exportar } \\
\text { esses dados em um arquivo. O biologista deve definir o nome do arquivo } \\
\text { e o diretório onde o mesmo será gravado. Por fim, o arquivo é gerado. }\end{array}$ \\
\hline
\end{tabular}

\section{Sequência típica de eventos}

\begin{tabular}{|l|l|}
\hline \multicolumn{1}{|c|}{ Ação do Ator } & \multicolumn{1}{c|}{ Resposta do sistema } \\
\hline $\begin{array}{l}\text { 1. Este caso de uso é iniciado quando o } \\
\text { biologista requisita a exportação de } \\
\text { dados previamente selecionados. }\end{array}$ & $\begin{array}{l}\text { 2. O sistema requisita nome do arquivo e } \\
\text { o diretório onde o mesmo será } \\
\text { armazenado. }\end{array}$ \\
\hline 3. O biologista informa o nome e o & 4. O sistema cria um arquivo texto com \\
\hline
\end{tabular}


diretório de armazenamento do arquivo.

formato delimitado por tabulações no diretório especificado contendo apenas os dados selecionados.

\begin{tabular}{|l|l|}
\hline Caso de Uso & Processar dados (Conector) \\
\hline Atores & Biologista (iniciador) \\
\hline Finalidade & $\begin{array}{l}\text { Recuperar e transformar dados obtidos pela contagem de genes em } \\
\text { valores de expressão gênica de modo a serem utilizados pela ferramenta } \\
\text { TMeV }\end{array}$ \\
\hline Visão Geral & $\begin{array}{l}\text { O biologista opta por realizar o processamento dos dados através do } \\
\text { conector responsável por normalizar os dados de modo a permitir a } \\
\text { integração das ferramentas DMV e TMeV. Por fim, a ferramenta TMeV } \\
\text { é ativada. }\end{array}$ \\
\hline
\end{tabular}

Sequência típica de eventos

\begin{tabular}{|l|l|}
\hline \multicolumn{1}{|c|}{ Ação do Ator } & \multicolumn{1}{c|}{ Ação do sistema } \\
\hline $\begin{array}{l}\text { 1. Este caso de uso é iniciado quando o } \\
\text { biologista informa a localização do } \\
\text { arquivo contendo os dados de entrada e } \\
\text { diretório esperado de armazenamento dos } \\
\text { dados de saída e requisita a } \\
\text { transformação dos dados para possibilitar } \\
\text { a integração das ferramentas DMV e } \\
\text { TMeV. }\end{array}$ & $\begin{array}{l}\text { 2. O sistema realiza a leitura do arquivo } \\
\text { de entrada informado que contém o } \\
\text { número de vezes que cada gene foi } \\
\text { identificado em uma condição } \\
\text { experimental. }\end{array}$ \\
\hline & $\begin{array}{l}\text { 3. O sistema realiza a leitura do arquivo } \\
\text { que contém o número total de genes } \\
\text { identificados em cada condição } \\
\text { experimental. }\end{array}$ \\
\hline & $\begin{array}{l}\text { 4. O sistema realiza a normalização que } \\
\text { consiste na divisão do número de vezes } \\
\text { que cada gene foi identificado pelo } \\
\text { número total de genes identificados em } \\
\text { uma condição experimental. }\end{array}$ \\
\hline & $\begin{array}{l}\text { 5. O sistema cria um arquivo no diretório } \\
\text { especificado que contém o resultado da } \\
\text { normalização. }\end{array}$ \\
\hline
\end{tabular}

Sequência alternativa de eventos

\begin{tabular}{|c|c|}
\hline Ação do Ator & Resposta do sistema \\
\hline $\begin{array}{l}\text { 1. Este caso de uso é iniciado quando o } \\
\text { biologista informa a localização do } \\
\text { arquivo contendo os dados de entrada e } \\
\text { diretório esperado de armazenamento } \\
\text { dos dados de saída e requisita a } \\
\text { transformação dos dados para } \\
\text { possibilitar a integração das ferramentas } \\
\text { DMV e TMeV. O biologista também } \\
\text { requisita a ativação automática da } \\
\text { ferramenta TMeV. }\end{array}$ & $\begin{array}{l}\text { 2. O sistema realiza a leitura do arquivo } \\
\text { de entrada informado que contém o } \\
\text { número de vezes que cada gene foi } \\
\text { identificado em uma condição } \\
\text { experimental. }\end{array}$ \\
\hline
\end{tabular}




\begin{tabular}{|l|l|}
\hline & $\begin{array}{l}\text { 3. O sistema realiza a leitura do arquivo } \\
\text { que contém o número total de genes } \\
\text { identificados em cada condição } \\
\text { experimental. }\end{array}$ \\
\hline $\begin{array}{l}\text { 4. O sistema realiza a normalização que } \\
\text { consiste na divisão do número de vezes } \\
\text { que cada gene foi identificado pelo } \\
\text { número total de genes identificados em } \\
\text { uma condição experimental. }\end{array}$ \\
\hline $\begin{array}{l}\text { 5. O sistema cria um arquivo no diretório } \\
\text { especificado que contém o resultado da } \\
\text { normalização. }\end{array}$ \\
\hline $\begin{array}{l}\text { 6. O sistema realiza a ativação automática } \\
\text { da ferramenta TMeV. }\end{array}$ \\
\hline
\end{tabular}

\begin{tabular}{|l|l|}
\hline Caso de Uso & Importar e carregar valores de expressão gênica (TMeV) \\
\hline Atores & Biologista (iniciador) \\
\hline Finalidade & $\begin{array}{l}\text { Carregar dados contidos em arquivos para que possam ser manipulados } \\
\text { pela ferramenta. }\end{array}$ \\
\hline Visão Geral & $\begin{array}{l}\text { O biologista opta por importar dados contidos em arquivos que estejam } \\
\text { em um dos formatos aceitosl pela ferramenta TMeV. Esses dados devem } \\
\text { estar devidamente normalizados para que possam ser clusterizados pela } \\
\text { ferramenta. }\end{array}$ \\
\hline
\end{tabular}

Sequência típica de eventos

\begin{tabular}{|l|l|}
\hline \multicolumn{1}{|c|}{ Ação do Ator } & \multicolumn{1}{c|}{ Resposta do sistema } \\
\hline $\begin{array}{l}\text { 1. Este caso de uso é iniciado quando o } \\
\text { biologista requisita a importação de } \\
\text { dados contidos em um arquivo. }\end{array}$ & $\begin{array}{l}\text { 2. O sistema informa os arquivos } \\
\text { existentes em um dado diretório e } \\
\text { requisita a seleção do arquivo desejado. }\end{array}$ \\
\hline $\begin{array}{l}\text { 3. O biologista informa o arquivo que } \\
\text { contém os dados de interesse. }\end{array}$ & $\begin{array}{l}\text { 4. Caso o arquivo esteja em um formato } \\
\text { aceito pelo sistema, os dados contidos } \\
\text { no arquivo são carregados de modo que } \\
\text { os mesmos possam ser clusterizados. }\end{array}$ \\
\hline
\end{tabular}

Sequência alternativa de eventos

\begin{tabular}{|l|l|}
\hline \multicolumn{1}{|c|}{ Ação do Ator } & \multicolumn{1}{c|}{ Resposta do sistema } \\
\hline $\begin{array}{l}\text { 1. Este caso de uso é iniciado quando o } \\
\text { biologista requisita a importação de } \\
\text { dados contidos em um arquivo. }\end{array}$ & $\begin{array}{l}\text { 2. O sistema informa os arquivos } \\
\text { existentes em um dado diretório e } \\
\text { requisita a seleção do arquivo desejado. }\end{array}$ \\
\hline $\begin{array}{l}\text { 3. O biologista informa o arquivo que } \\
\text { contém os dados de interesse. }\end{array}$ & $\begin{array}{l}\text { 4. Caso o arquivo não esteja em um } \\
\text { formato aceito pelo sistema, os dados } \\
\text { contidos no arquivo não são carregados } \\
\text { e uma mensagem de erro é exibida. }\end{array}$ \\
\hline
\end{tabular}




\section{D4. Descrição detalhada dos dados de interesse}

A Figura 43 ilustra uma representação da integração das ferramentas DMV e TMeV através do conector $C_{2}$. A ferramenta DMV e o conector $C_{1.2}$ geram os dados que servirão de entrada para o conector $\mathrm{C}_{2}\left(\mathrm{EC}_{2}\right)$, enquanto que a ferramenta $\mathrm{TMeV}$ consome os dados que serão produzidos pelo mesmo $\left(\mathrm{SC}_{2}\right)$. A descrição detalhada dos dados de interesse (entrada e saída associadas ao conector) está relacionada às funcionalidades $\mathrm{DMV}_{13}$ e $\mathrm{TMEV}_{1}$ das ferramentas DMV e TMeV, respectivamente.

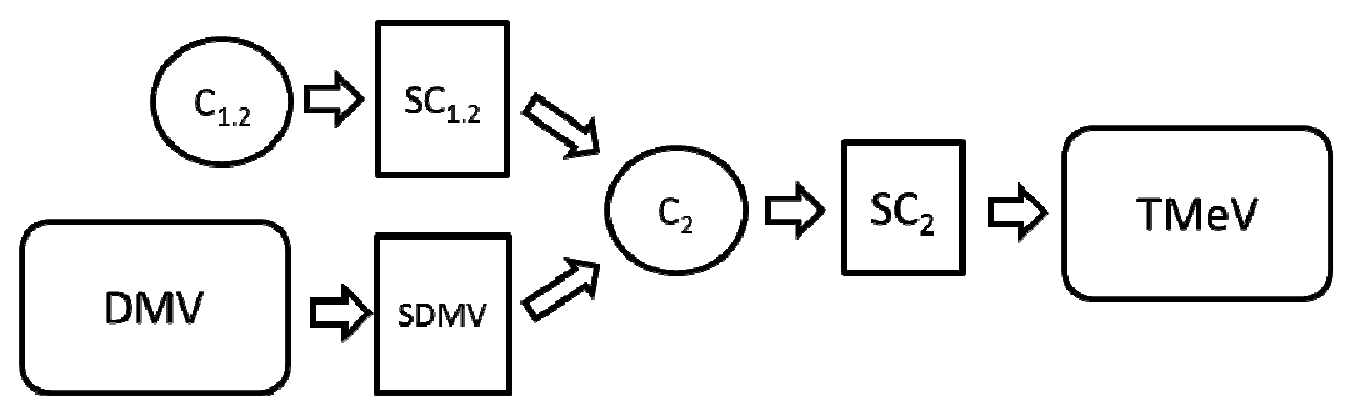

Figura 43: Integração das ferramentas DMV e TMeV através do conector $C_{2}$

Funcionalidade responsável por gerar os dados de entrada do conector $\left(\mathrm{DMV}_{13}\right)$ : Exportar dados selecionados pela ferramenta em arquivo.

$\mathbf{E C}_{2}$ : Os dados de entrada do conector consistem nos dados gerados pela ferramenta DMV como resultado da funcionalidade $\mathrm{DMV}_{13}$ (SDMV) e nos dados gerados pelo conector $\mathrm{C}_{1.2}$ $\left(\mathrm{SC}_{1.2}\right)$. A descrição dos dados gerados pelo conector $\mathrm{C}_{1.2}\left(\mathrm{SC}_{1.2}\right)$ foi realizada na seção $\mathrm{C} 4.2$ do Apêndice C. Esses dados devem estar contidos em um arquivo texto que representem uma matriz na qual cada coluna deve apresentar uma condição experimental e uma linha de dados deve informar o número total de genes obtidos de acordo com cada condição. A Tabela 15 apresenta a descrição desses dados.

Tabela 15: Descrição dos dados de saída do conector $\mathbf{C}_{1.2}$

\begin{tabular}{|r|l|l|}
\hline Item de dado & \multicolumn{1}{|c|}{ Descrição semântica } & \multicolumn{1}{|c|}{ Sintaxe de representação } \\
\hline $\begin{array}{r}\text { Condição } \\
\text { experimental }\end{array}$ & $\begin{array}{l}\text { Dado que descreve a condiçăo experimental na qual } \\
\text { foram obtidas sequéncias que podem representar } \\
\text { genes, visando obter valores de expressão gênica }\end{array}$ & $\begin{array}{l}\text { Conjunto de valores do tipo String apresentados na } \\
\text { primeira linha da matriz de dados contido em um } \\
\text { arquivo texto delimitado por tabulações }\end{array}$ \\
\hline $\begin{array}{r}\text { Número total de } \\
\text { genes }\end{array}$ & $\begin{array}{l}\text { Dado que representa a quantidade total de genes que } \\
\text { foram obtidos de acordo com uma condição } \\
\text { experimental }\end{array}$ & $\begin{array}{l}\text { Conjunto de valores do tipo inteiro contidos na } \\
\text { segunda linha da matriz de dados contido em um } \\
\text { arquivo texto delimitado por tabulaçōes }\end{array}$ \\
\hline
\end{tabular}


Os dados de entrada do conector $\mathrm{C}_{2}$ também são formados pelos dados gerados pela ferramenta DMV. Esses dados devem estar contidos em arquivo texto com formato delimitado por tabulações. A representação dos dados é feita através de uma matriz na qual cada linha deve representar um gene e cada coluna uma condição experimental. Os valores da matriz devem associar um gene a uma condição e consistir de valores numéricos que representam o número de vezes que cada um desses genes foi identificado em uma condição. A Tabela 16 apresenta a descrição desses dados.

Tabela 16: Descrição dos dados relacionados à saída da funcionalidade $\mathrm{DMV}_{13}$

\begin{tabular}{|r|l|l|}
\hline \multicolumn{1}{|c|}{ Item de dado } & \multicolumn{1}{|c|}{ Descrição semântica } & \multicolumn{1}{c|}{ Sintaxe de representação } \\
\hline $\begin{array}{r}\text { Identificador de } \\
\text { um gene }\end{array}$ & $\begin{array}{l}\text { Dado que representa um identificador de } \\
\text { um gene }\end{array}$ & $\begin{array}{l}\text { Conjunto de valores do tipo String apresentados } \\
\text { na primeira coluna da matriz de dados em um } \\
\text { arquivo texto delimitado por tabulações }\end{array}$ \\
\hline $\begin{array}{r}\text { Condição } \\
\text { experimental }\end{array}$ & $\begin{array}{l}\text { Dado que descreve a condição experimental } \\
\text { na qual um dado valor de expressão gênica } \\
\text { foi obtida }\end{array}$ & $\begin{array}{l}\text { Conjunto de valores do tipo String apresentados } \\
\text { na primeira linha da matriz de dados em um } \\
\text { arquivo texto delimitado por tabulações }\end{array}$ \\
\hline $\begin{array}{r}\text { Quantidade de de } \\
\text { genes }\end{array}$ & $\begin{array}{l}\text { Dado que representa a quantidade de vezes } \\
\text { que um gene aparece dada uma condição } \\
\text { experimental }\end{array}$ & $\begin{array}{l}\text { Conjunto de valores do tipo inteiro contidos em } \\
\text { uma matriz de dados em um arquivo texto } \\
\text { delimitado por tabulações }\end{array}$ \\
\hline
\end{tabular}

\section{Funcionalidade responsável por consumir os dados gerados pelo conector $\left(\mathrm{TMEV} \mathrm{V}_{1}\right)$ :}

Importar dados de arquivos em formatos específicos para realizar a clusterização dos mesmos. $\mathbf{S C}_{2}$ : Os dados de saída do conector consistem nos dados consumidos pela ferramenta TMeV através da funcionalidade $\mathrm{TMEV}_{1}$. Esses dados devem estar contidos em arquivos texto cujo formato é delimitado por tabulações. Para o cenário de integração adotado, os dados consumidos devem consistir de uma matriz em que cada linha deve representar um gene e cada coluna uma condição experimental. Os valores da matriz devem consistir de valores baseados em contagens que representam uma medição relativa da expressão de um gene obtida de acordo com uma condição experimental. A clusterização dos dados, disponível pela ferramenta, é aplicada nesses dados. A Tabela 17 apresenta a descrição desses dados. 
Tabela 17: Descrição dos dados de entrada relacionados à funcionalidade $T M E V_{1}$ e à saída do conector

\begin{tabular}{|c|c|c|}
\hline Item de dado & Descrição semântica & Sintaxe de representação \\
\hline $\begin{array}{r}\text { Identificador de } \\
\text { um gene }\end{array}$ & $\begin{array}{l}\text { Dado que representa um identificador de um } \\
\text { gene }\end{array}$ & $\begin{array}{l}\text { Conjunto de valores do tipo String apresentados na primeira } \\
\text { coluna da matriz de dados de um arquivo texto delimitado } \\
\text { por tabulaçooss }\end{array}$ \\
\hline $\begin{array}{r}\text { Condição } \\
\text { experimental }\end{array}$ & $\begin{array}{l}\text { Dado que descreve a condição experimental na } \\
\text { qual um dado valor de expressào gênica foi } \\
\text { obtido }\end{array}$ & $\begin{array}{l}\text { Conjunto de valores do tipo String apresentados na primeira } \\
\text { linha da matriz de dados de um arquivo texto delimitado } \\
\text { por tabulações }\end{array}$ \\
\hline $\begin{array}{r}\text { Valor de } \\
\text { expressão gênica }\end{array}$ & $\begin{array}{l}\text { Dado que represcnta um valor de cxpressào } \\
\text { génica associado a um gene dada uma condiçăo } \\
\text { experimental }\end{array}$ & $\begin{array}{l}\text { Conjunto de valores do tipo ponto flutuante contidos cm } \\
\text { uma matriz de dados de um arquivo texto delimitado por } \\
\text { tabulaçues }\end{array}$ \\
\hline
\end{tabular}

\section{D5. Modelagem conceitual dos dados de interesse}

A modelagem conceitual dos dados de interesse associados à entrada do conector $\mathrm{C}_{2}$ $\left(\mathrm{EC}_{2}\right)$ consiste de dois modelos conceituais, um para representa os dados gerados pelo conector $\mathrm{C}_{1.2}$ e outro para representar os dados gerados pela ferramenta DMV. A Figura 44 ilustra a modelagem conceitual dos dados associados à saída do conector $\mathrm{C}_{1.2}\left(\mathrm{SC}_{1.2}\right)$. Esses dados representam o resultado gerado pelo conector responsável pela contagem do número total de genes obtidos de acordo com cada uma das condições experimentais. Cada arquivo de dados representa uma condição experimental. Nesta situação os seguintes conceitos foram identificados: Condicao_Experimental, que representa a condição experimental em que os genes são submetidos para a medição da expressão gênica; Total_Genes, que representa o número total de genes identificados de acordo com uma condição experimental.

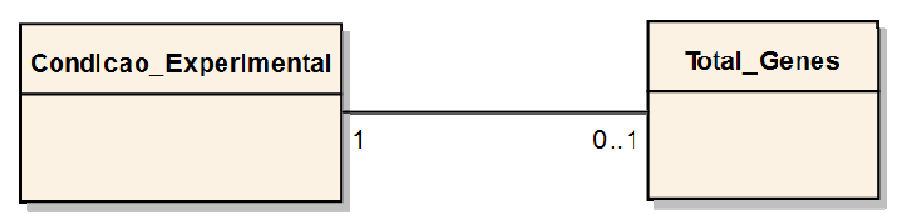

Figura 44: Modelagem conceitual associada à saída do conector $C_{1.2}$

A Figura 45 ilustra a modelagem conceitual dos dados associados à saída da ferramenta DMV (SDMV). A partir da descrição detalhada dos dados de interesse é possível identificar gene e condição experimental. Cada gene é cruzado com uma condição experimental gerando um número de vezes que o gene foi obtido de acordo com a condição. Dessa forma, para cada quantidade de genes existe um gene e uma condição experimental associados. 
Os seguintes conceitos foram identificados: Gene, que representa um gene cuja sequência de bases representante foi identificada; Condicao_Experimental, que representa a condição experimental em que os experimentos foram submetidos para a obtenção dos dados; Quantidade_Genes, que representa um valor que quantifica o número de vezes que um Gene foi obtido de acordo com uma determinada condição experimental. Quantidade_Genes foi modelada como uma classe de associação definida entre Condicao_Experimental e Gene.

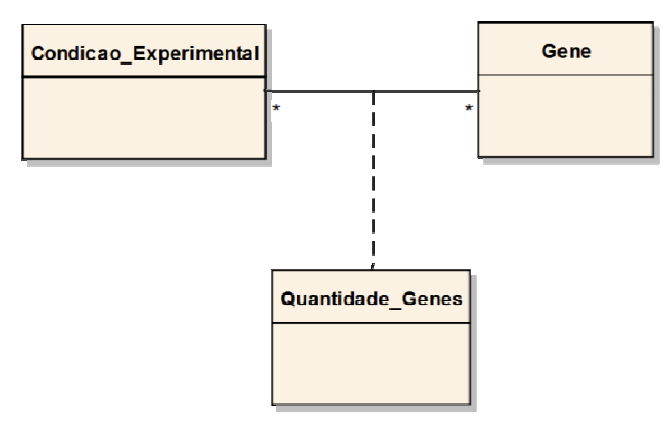

Figura 45: Modelagem conceitual associada à saída da ferramenta DMV

A Figura 46 ilustra a modelagem conceitual dos dados de interesse associados à saída do conector $\left(\mathrm{SC}_{2}\right)$. A clusterização dos dados deve ser realizada sobre valores normalizados que representam a medição relativa de expressão gênica. A normalização é realizada através do cálculo da razão entre a quantidade de vezes que um gene é obtido de acordo com uma condição experimental pelo número total de genes relacionados à mesma. Assim, a partir da descrição detalhada dos dados de interesse é possível identificar genes e condições experimentais. Cada gene é cruzado com uma condição experimental gerando um valor de expressão gênica associado. Dessa forma, para cada valor de expressão gênica existe um gene e uma condição experimental associados.

Os seguintes conceitos foram identificados: Gene, que representa um gene cujo valor de expressão gênica foi mensurado; Condicao_Experimental, que representa a condição experimental em que os genes são submetidos para a medição da expressão gênica e Valor_Expressao_Genica, que representa um valor que quantifica o nível que um Gene está expresso através de uma medição relativa. Valor_Expressao_Genica foi modelado como uma classe de associação definida entre Condicao_Experimental e Gene. 


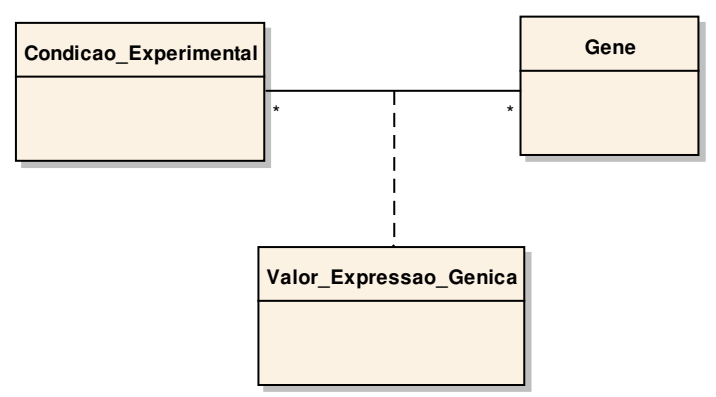

Figura 46: Modelagem conceitual associada à saída do conector $\mathrm{C}_{2}$ (segundo estudo de caso)

\section{D6. Mapeamento para ontologia de referência}

A Tabela 18 apresenta o mapeamento entre os conceitos associados à entrada e à saída do conector aos conceitos da ontologia de referência.

Tabela 18: Mapeamento dos conceitos associados à entrada e saída do conector $\mathrm{C}_{2}$ (segundo estudo de caso) a conceitos da ontologia de referência

\begin{tabular}{|c|c|c|}
\hline $\begin{array}{c}\text { Conceito entrada } \\
\text { conector }\end{array}$ & $\begin{array}{c}\text { Conceito ontologia } \\
\text { referência }\end{array}$ & $\begin{array}{c}\text { Conceito saída } \\
\text { conector }\end{array}$ \\
\hline Gene & Gene & Gene \\
\hline Condicao_Experimental & Experimental_Condition & Condicao_Experimental \\
\hline Quantidade_Genes & Sampled_Gene_Amount & \\
\hline Total_Genes & Total_Sampled_Gene_Amount & \\
\hline & Count_Based_Value & Valor_Expressao_Genica \\
\hline
\end{tabular}

Neste mapeamento todos os conceitos foram mapeados para conceitos da ontologia de referência. Contudo os conceitos relacionados à entrada do conector, Quantidade_Genes e Total_Genes, associados aos conceitos Sampled_Gene_Amount e Total_Gene_Amount da ontologia de referência respectivamente, não possuem conceitos de saída associados. Além disso, o conceito relacionado à saída do conector, Valor_Expressao_ Genica, associado ao conceito Count_Based_Value da ontologia de referência, não possui um conceito de entrada do conector associado.

A falta de associação entre os conceitos de entrada e saída é justificada pela transformação dos dados de entrada realizada pelo conector $\mathrm{C}_{2}$ em valores que representam Valor_Expressao_Genica. Dessa forma, apesar de não existir uma associação direta entre os 
conceitos Quantidade_Genes, Total_Genes e Valor_Expressao_Genica, o último conceito pode ser obtido utilizando o primeiro e o segundo conceitos. Dessa forma, Valor_Expressao_ Genica pode ser obtido a partir do cálculo da razão entre Quantidade_Genes e Total_Genes.

A Tabela 19 apresenta a adequação do mapeamento dos conceitos associados à entrada e saída do conector a conceitos da ontologia. Para essa situação não foi necessário inserir novos conceitos na ontologia de referência, mas é necessária uma transformação semântica dos dados para tornar possível a associação entre conceitos distintos associados à entrada e à saída do conector e assim possibilitar um mapeamento completo de todos os conceitos.

Tabela 19: Mapeamento revisado dos conceitos associados à entrada e saída do conector $\mathrm{C}_{2}$ (segundo estudo de caso) a conceitos da ontologia de referência

\begin{tabular}{|c|c|c|}
\hline $\begin{array}{c}\text { Conceito entrada } \\
\text { conector }\end{array}$ & $\begin{array}{c}\text { Conceito ontologia } \\
\text { referência }\end{array}$ & $\begin{array}{c}\text { Conceito saída } \\
\text { conector }\end{array}$ \\
\hline Gene & Gene & Gene \\
\hline Condicao_Experimental & Experimental_Condition & Condicao_Experimental \\
\hline $\begin{array}{c}\text { (Quantidade_Genes e } \\
\text { Total_Genes })\end{array}$ & Count_Based_Value & Valor_Expressao_Genica \\
\hline
\end{tabular}

\section{D7. Adequação dos dados de interesse}

Os dados gerados por DMV estão contidos em arquivos texto e consistem de uma matriz de dados previamente filtradas que contém informações sobre o número de vezes que cada gene de um subconjunto de genes foi obtido de acordo com uma condição experimental. Os dados gerados pelo conector $\mathrm{C}_{1.2}$ também estão contidos em arquivos texto e consistem de uma matriz de dados que informa o número total de genes identificados de acordo com uma condição experimental. A adequação sintática dos dados consiste na conversão dos dados extraídos desses arquivos texto em dados numéricos e textuais.

A adequação semântica dos dados consiste na transformação dos dados numéricos e textuais em representações dos conceitos identificados na modelagem conceitual. Dessa forma os valores de dados numéricos devem ser transformados para serem associados a valores de expressão gênica, enquanto que os valores textuais devem ser associados a informações sobre genes e condições experimentais. Para associar os dados numéricos a valores de expressão gênica deve ser realizada uma transformação nesses dados. Essa transformação consiste na normalização cujo objetivo é tornar viável a clusterização e gerar resultados com significância 
biológica. Os dados normalizados representam uma medição relativa da expressão gênica. A normalização deve ser realizada pelo conector e consiste na divisão do número de vezes que um gene é obtido de acordo com uma dada condição experimental pelo número total de genes identificados de acordo com a mesma. Dessa forma é possível gerar dados numéricos que representam valores de expressão gênica.

\section{D8. Identificação de políticas de acesso e ativação}

A ferramenta $\mathrm{TMeV}$ disponibiliza acesso local às suas funcionalidades e pode ser instalada em qualquer diretório. Não existe restrição de acesso a essa ferramenta. A transferência de controle pode ser manual ou automática a partir da execução do conector.

\section{D9. Implementação do conector}

A Figura 47 ilustra o diagrama de classes UML do conector $\mathrm{C}_{2}$. Todas as classes foram implementadas utilizando a linguagem de programação Java.

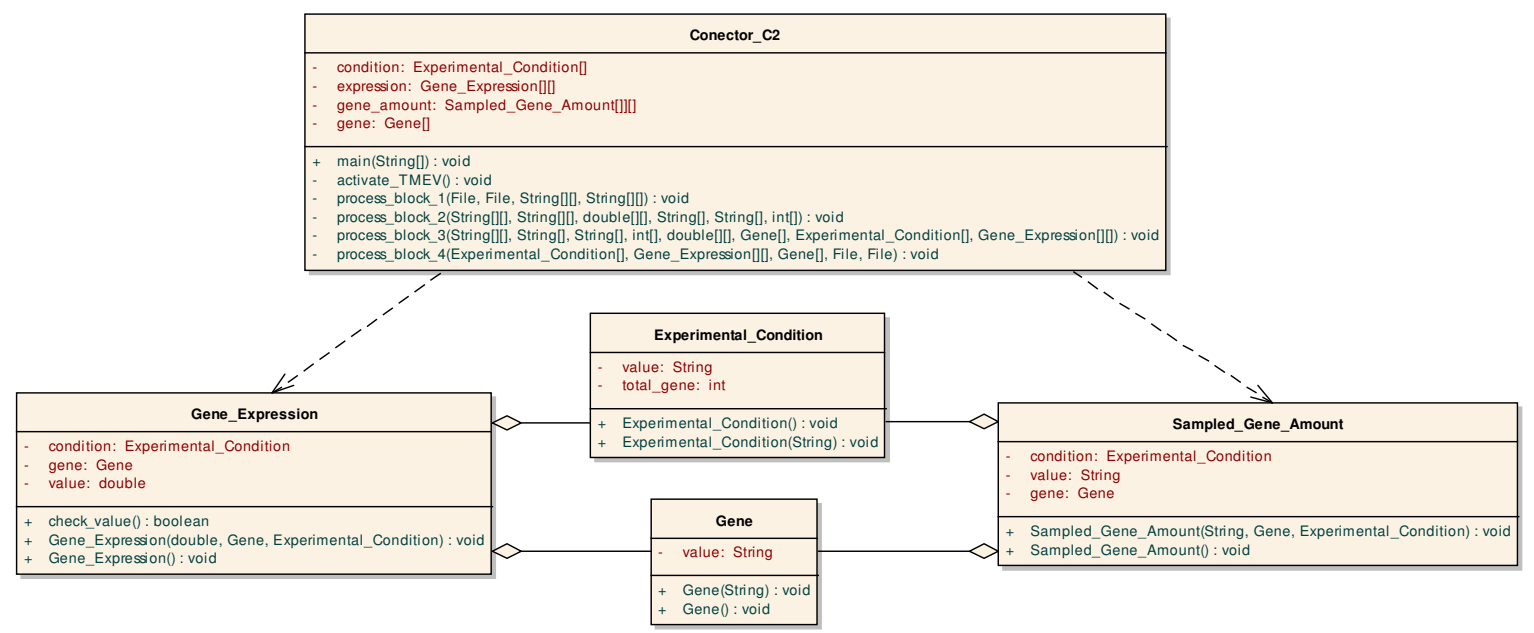

Figura 47: Diagrama de classes do conector $C_{2}$ (segundo estudo de caso)

As classes Experimental_Condition, Sampled_Gene_Amount, Gene e Gene_Expression foram criadas a partir dos conceitos identificados nos modelos conceituais. Gene é uma classe para representação de genes e, neste caso, armazena o identificador do gene. Experimental_Condition é uma classe para representação de condições experimentais nas quais os genes são submetidos para medição da expressão gênica e armazena um número total de genes que são identificados associados à condição, se houver. Sampled_Gene_Amount é uma classe para representação do número de vezes que um gene 
foi identificado de acordo com uma condição experimental. Gene_Expression é uma classe para representação dos valores de expressão gênica baseados em contagem relacionado a um gene em uma condição experimental. Esses valores são calculados através da razão entre o valor atribuído a Sampled_Gene_Amount e o número total de genes identificadas em uma condição experimental obtido como resultado do desenvolvimento do conector $\mathrm{C}_{1}$. Esse número total está representado como um atributo de Experimental_Condition.

Os blocos funcionais da classe Conector_C2, implementados como métodos da mesma, são executados sequencialmente, de modo que um bloco é executado somente após o término do bloco anterior. Os atributos dessa classe consistem de um vetor de genes (Gene), um vetor de condições experimentais (Experimental_Condition), uma matriz de valores de expressão gênica (Gene_Expression) e uma matriz das quantidades de vezes que cada gene foi obtido em uma amostra (Sampled_Gene_Amount). O método main recebe como parâmetros o identificador do diretório que contém os arquivos com os dados de entrada, o identificador do diretório onde serão armazenados os dados de saída desse conector e o identificador do arquivo utilizado na ativação automática da ferramenta, se houver. O método process_block1 realiza o processamento inicial dos dados. Esse método recebe como parâmetros dois identificadores de arquivo (File), um para cada arquivo de entrada e duas matrizes de String para armazenar os dados contidos nesses arquivos. O primeiro identificador (File) representa o arquivo que contém dados gerados pela ferramenta DMV e o segundo identificador representa o arquivo gerado pelo primeiro conector deste estudo de caso, que contém informações sobre o total de genes associados a cada condição experimental. Os dados são carregados e disponibilizados em duas matrizes de String.

O método process_block2 realiza a adequação sintática através da transformação dos dados extraídos dos arquivos de entrada (matrizes de String) em dados numéricos e textuais de acordo com a informação que representam. Esse método recebe como parâmetros duas matrizes de String que contém os dados que foram extraídos de cada arquivo de entrada, uma matriz de double, que armazena os valores contidos na matriz do arquivo gerado por DMV, dois vetores de String que armazenam os valores do cabeçalho contidos na primeira linha e na primeira coluna da matriz desse arquivo e um vetor de inteiros, que armazena os valores armazenados no arquivo obtidos através do conector $\mathrm{C}_{1}$.

O método process_block3 realiza a transformação semântica dos dados através da transformação das estruturas de dados definidas e instanciadas em process_block2 em 
instâncias das classes criadas a partir da modelagem conceitual (associação semântica). Esse método recebe como parâmetros uma matriz de String que contém os dados que foram extraídos do arquivo, uma matriz de double, que armazena os valores contidos no conteúdo da matriz, dois vetores de String que armazenam os valores do cabeçalho contidos na primeira linha e na primeira coluna da matriz, um vetor de inteiros, que armazena os valores obtidos pelo conector $\mathrm{C}_{1}$, e dados que são preenchidos nesse método, um vetor de genes (Gene), um vetor de condições experimentais (Experimental_Condition), e um vetor de dados de expressão gênica (Gene_Expression). A transformação dos dados que representam o número de vezes que cada gene foi obtido em uma amostra (Sampled_Gene_Amount) em dados de expressão gênica (Gene_Expression) deve ser realizada. Essa transformação é feita através da divisão dos valores de instâncias de cada número de vezes (Sampled_ Gene_Amount) pelo número total de genes obtidos de acordo com uma determinada condição experimental.

O método process_block4 realiza o processamento dos dados de saída do conector e pela ativação automática da ferramenta $\mathrm{TMeV}$. Esse método recebe como parâmetros uma matriz de dados de expressão gênica (Gene_Expression), um vetor de genes (Gene), um vetor de condições experimentais (Experimental_Condition), todos contendo dados que serão salvos em um arquivo, e dois identificadores de arquivo (File), um para o diretório onde esse arquivo será criado e outro identificador para o arquivo responsável pela ativação automática da ferramenta TMeV. A ativação automática é implementada através da função activate_TMeV e realiza a transferência de controle (passagem da thread de execução) para a ferramenta TMeV através da execução de um arquivo com extensão bat como um processo. Esse arquivo, bem como o código fonte do $\mathrm{TMeV}$, são disponibilizados pelos desenvolvedores dessa ferramenta. 


\section{APÊNDICE E - Desenvolvimento do conector entre banco de dados e a ferramenta RGui - Terceiro estudo de caso.}

O terceiro estudo de caso envolve a integração de um banco de dados contendo informações biológicas às ferramentas RGui e DAVID. Dois conectores serão responsáveis por essa integração. $\mathrm{O}$ conector $\mathrm{C}_{1}$ é o responsável pela integração do banco de dados do NCBI à ferramenta RGui. Os principais aspectos da aplicação da abordagem para este estudo de caso, com o objetivo de promover o desenvolvimento desse conector, estão especificados neste apêndice.

O banco de dados é um repositório de dados público que contém dados genômicos funcionais sobre experimentos e perfis de expressão gênica. A linguagem R é utilizada, em geral, como ferramenta para realizar análise exploratória de dados, cálculos estatísticos e gráficos. RGui é uma interface gráfica que possibilita a utilização dessa linguagem.

\section{E1. Identificação das principais funcionalidades das ferramentas envolvidas}

Listagem funcional da ferramenta RGui:

O Apêndice A (seção A1) apresenta a listagem funcional desta ferramenta.

\section{E2. Descrição inicial do cenário de integração}

Subconjunto de funcionalidades diretamente relacionadas ao cenário de integração:

$\mathbf{R}_{\mathbf{1}}$ : Importar dados. Esses dados devem estar contidos em arquivo cujo formato é aceito por esta ferramenta. Os dados importados são carregados pela mesma.

$\mathbf{R}_{5}$ : Exportar dados em arquivo. O formato desse arquivo deve ser especificado pelo usuário. $\mathbf{R}_{\mathbf{1 2}}$ : Aplicar função para realizar teste de hipóteses: "teste $\mathrm{t}$ "

O cenário envolve a integração do banco de dados do NCBI aos serviços providos pela ferramenta RGui. Os dados contidos no banco são resultados da execução de uma abordagem baseada em hibridização do tipo microarray one-color. Esses dados estão estruturados em uma matriz e contidos em arquivos texto cujo formato é delimitado por tabulações, acessados localmente. Nessa matriz estão representados identificadores de genes e seus respectivos valores de expressão. Os dados são extraídos do banco e processados de modo a serem utilizados pela ferramenta RGui para realizar testes de hipóteses. 
Os dados utilizados em testes de hipóteses devem consistir de valores produzidos a partir da execução de abordagens microarray two-color para gerar resultados estatisticamente significantes. Dessa forma, é possível realizar uma análise estatística coerente do resultado da aplicação de testes de hipóteses (teste t) nos dados.

Os dados extraídos do banco de dados, que consistem de dados obtidos de abordagens one-color, devem ser transformados em dados de abordagens two-color. Essa transformação consiste no cálculo da razão entre dois valores de expressão gênica obtidos de abordagens one-color associados a um mesmo gene de indivíduos distintos. Dessa forma é possível gerar valores simulados de abordagens two-color. Para realizar essa transformação são realizados dois tipos de cruzamentos dos dados. O primeiro consiste no cruzamento de dados derivados de indivíduos submetidos à mesma condição experimental representando a mesma categoria (intragrupos) e o segundo consiste no cruzamento de dados derivados de indivíduos submetidos a condições distintas representando categorias distintas (intergrupos). Para cada tipo de cruzamento um arquivo é gerado.

Após processamento dos dados, o usuário do ambiente integrado da linguagem $\mathrm{R}$ (RGui) importa os dados contidos nos dois arquivos gerados. Esses dados são carregados em matrizes e disponibilizados para uso $\left(\mathbf{R}_{\mathbf{1}}\right)$. Em seguida o usuário realiza a aplicação de testes de hipóteses nesses dados utilizando uma função de teste t disponível em RGui $\left(\mathbf{R}_{\mathbf{1 2}}\right)$. Como resultado RGui gera uma lista de genes com seus respectivos valores resultado do teste t. $\mathrm{O}$ usuário então exporta os dados resultantes para um arquivo texto com formato delimitado por tabulações $\left(\mathbf{R}_{\mathbf{5}}\right)$.

\section{E3. Descrição detalhada do cenário de integração}

A Figura 48 ilustra o diagrama de atividades elaborado a partir da descrição inicial do cenário de integração. As atividades "Transformação dos dados para valores obtidos por abordagens two-color (cruzamentos intergrupos)" e "Transformação dos dados para valores obtidos por abordagens two-color (cruzamentos intragrupos)” são realizadas pelo conector, enquanto que as atividades "Importação de dados contidos em um arquivo", "Aplicação de teste de hipóteses" e "Exportação dos dados resultantes em arquivo” são realizadas pela ferramenta RGui. 


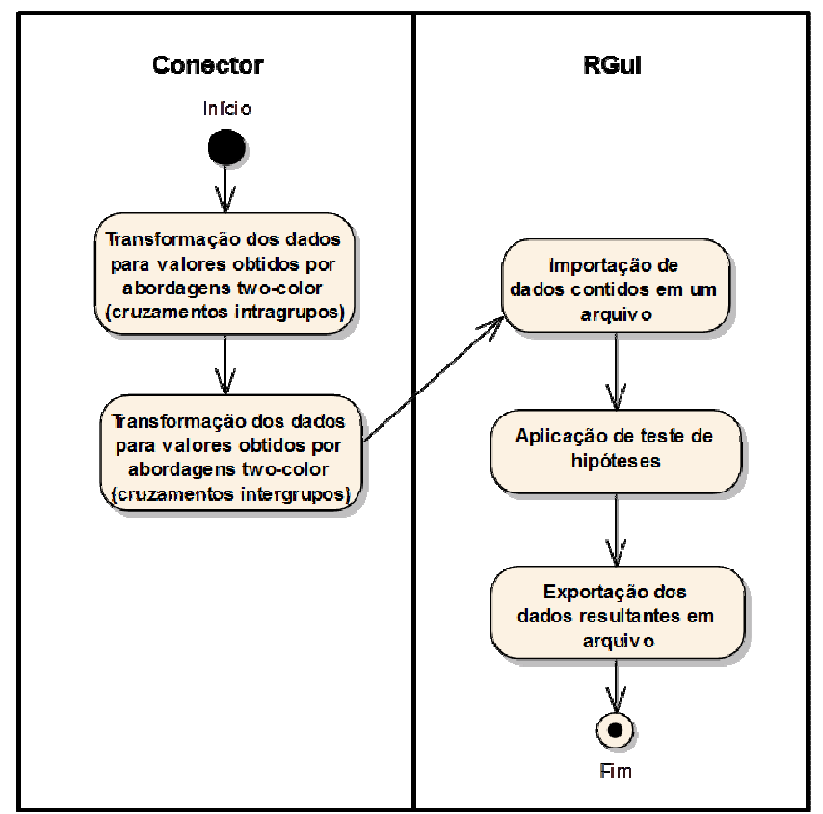

Figura 48: Diagrama de atividades relacionado ao desenvolvimento do conector $C_{1}$ (terceiro estudo de caso)

A Figura 49 ilustra os casos de uso derivados do diagrama de atividades. Os casos de uso "Processar dados", "Transformar dados obtidos por abordagens one-color em dados obtidos por abordagens two-color através do cruzamento de indivíduos do mesmo grupo (cruzamentos intragrupos)" e "Transformar dados obtidos por abordagens one-color em dados obtidos por abordagens two-color através do cruzamento de indivíduos de grupos distintos (cruzamentos intergrupos)” estão associados ao conector, enquanto que os casos de uso "Importar e carregar dados em uma matriz”, “Aplicar teste de hipóteses nos dados” e “Exportar dados em arquivo” estão associados à ferramenta RGui. Os casos de uso de interesse foram identificados em cinza. A descrição detalhada desses casos de uso é apresentada na seção E3.1. 


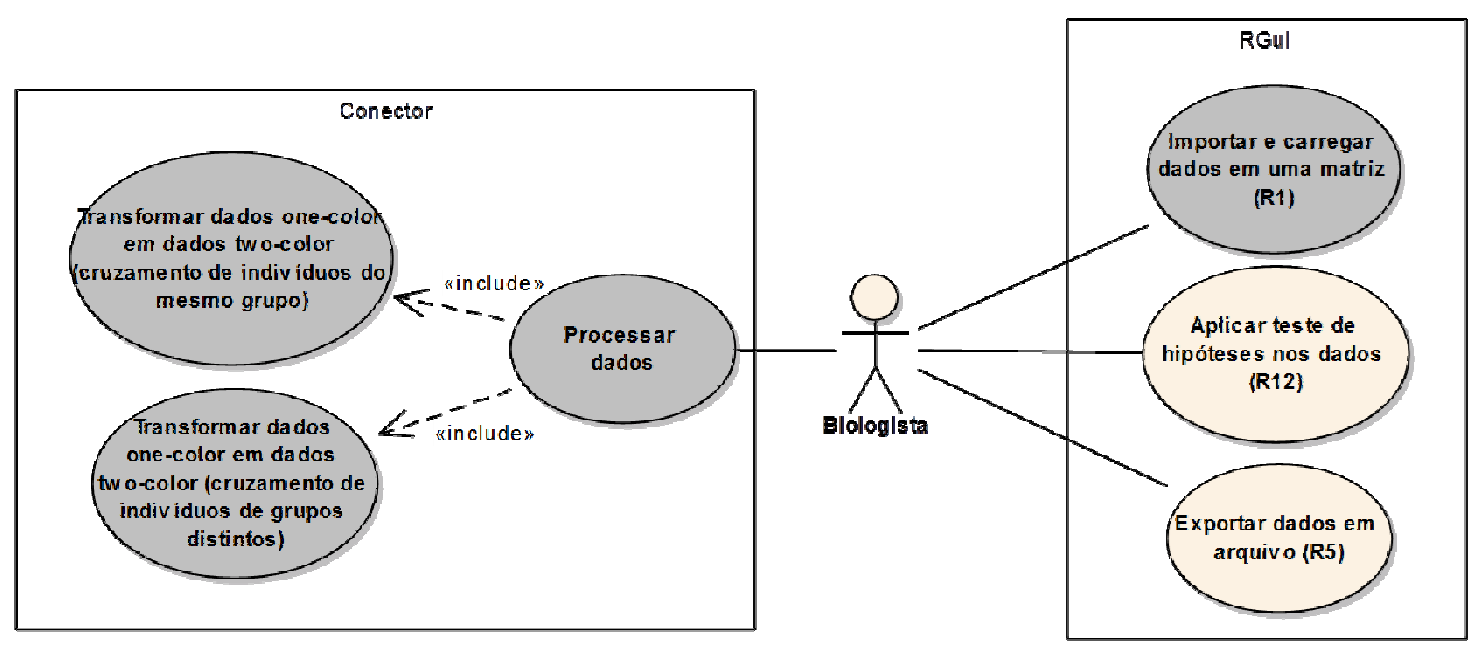

Figura 49: Diagrama de casos de uso relacionado ao desenvolvimento do conector $\mathrm{C}_{1}$ (terceiro estudo de caso)

\section{E3.1. Casos de uso expandido}

\begin{tabular}{|l|l|}
\hline Caso de Uso & Processar dados (Conector) \\
\hline Atores & Biologista (iniciador) \\
\hline Finalidade & $\begin{array}{l}\text { Recuperar e transformar dados de expressão gênica, gerados de } \\
\text { abordagens one-color em dados gerados de abordagens two-color, de } \\
\text { modo a serem utilizados pela ferramenta RGui. }\end{array}$ \\
\hline Visão Geral & $\begin{array}{l}\text { O biologista opta por realizar a transformação dos dados objetivando a } \\
\text { integração de uma base de dados à ferramenta RGui. Essa integração é } \\
\text { realizada por um conector responsável pelo processamento dos dados. } \\
\text { Neste caso, o processamento envolve a transformação dos dados obtidos } \\
\text { por abordagens one-color em dados obtidos por abordagens two-color. } \\
\text { Essa transformação realiza o cruzamento de dados de indivíduos do } \\
\text { mesmo grupo e o cruzamento de dados de indivíduos de grupos } \\
\text { distintos. Por fim, a ferramenta RGui é ativada. }\end{array}$ \\
\hline
\end{tabular}

Sequência típica de eventos

\begin{tabular}{|l|l|}
\hline \multicolumn{1}{|c|}{ Ação do Ator } & \multicolumn{1}{c|}{ Resposta do sistema } \\
\hline $\begin{array}{l}\text { 1. Este caso de uso é iniciado quando o } \\
\text { biologista informa a localização dos } \\
\text { arquivos contendo os dados de entrada e } \\
\text { o diretório esperado de armazenamento } \\
\text { dos dados de saída e requisita a } \\
\text { transformação dos dados para possibilitar } \\
\begin{array}{l}\text { a integração da base de dados à } \\
\text { ferramenta RGui. }\end{array}\end{array}$ & $\begin{array}{l}\text { 2. O sistema executa o caso de uso } \\
\text { Transformar dados obtidos por } \\
\text { abordagens one-color em dados } \\
\text { obtidos por abordagens two-color } \\
\text { (cruzamento de indivíduos do mesmo } \\
\text { grupo) }\end{array}$ \\
\hline & $\begin{array}{l}\text { 3. O sistema executa o caso de uso } \\
\text { Transformar dados obtidos por } \\
\text { abordagens one-color em dados } \\
\text { obtidos por abordagens two-color } \\
\text { (cruzamento de individuos de grupos }\end{array}$ \\
\hline
\end{tabular}




\begin{tabular}{|c|c|}
\hline & distintos) \\
\hline \multicolumn{2}{|c|}{ Sequência alternativa de eventos } \\
\hline Ação do Ator & Resposta do sistema \\
\hline \multirow[t]{3}{*}{$\begin{array}{l}\text { 1. Este caso de uso é iniciado quando o } \\
\text { biologista informa a localização dos } \\
\text { arquivos contendo os dados de entrada e } \\
\text { o diretório esperado de armazenamento } \\
\text { dos dados de saída e requisita a } \\
\text { transformação dos dados para possibilitar } \\
\text { a integração da base de dados à } \\
\text { ferramenta RGui. O biologista também } \\
\text { requisita a ativação automática da } \\
\text { ferramenta RGui. }\end{array}$} & $\begin{array}{l}\text { 2. O sistema executa o caso de uso } \\
\text { Transformar dados obtidos por } \\
\text { abordagens one-color em dados } \\
\text { obtidos por abordagens two-color } \\
\text { (cruzamento de indivíduos do mesmo } \\
\text { grupo) }\end{array}$ \\
\hline & $\begin{array}{l}\text { 3. O sistema executa o caso de uso } \\
\text { Transformar dados obtidos por } \\
\text { abordagens one-color em dados } \\
\text { obtidos por abordagens two-color } \\
\text { (cruzamento de indivíduos de grupos } \\
\text { distintos) }\end{array}$ \\
\hline & $\begin{array}{l}\text { 4. O sistema realiza a ativação automática } \\
\text { da ferramenta RGui. }\end{array}$ \\
\hline
\end{tabular}

\begin{tabular}{|l|l|}
\hline Caso de Uso & $\begin{array}{l}\text { Transformar dados obtidos por abordagens one-color em dados obtidos } \\
\text { por abordagens two-color através do cruzamento de indivíduos do } \\
\text { mesmo grupo - cruzamento intragrupos (Conector) }\end{array}$ \\
\hline Atores & Biologista (indireto) \\
\hline Finalidade & $\begin{array}{l}\text { Transformar dados obtidos por abordagens one-color em dados obtidos } \\
\text { por abordagens two-color realizando o cruzamento de dados de } \\
\text { indivíduos de mesma categoria. }\end{array}$ \\
\hline Visão Geral & $\begin{array}{l}\text { Os dados extraídos do banco de dados NCBI consistem de resultados de } \\
\text { abordagens one-color derivados de indivíduos de diversas categorias. } \\
\text { Esses dados são transformados em dados de abordagens two-color } \\
\text { obtidos através da razão entre dois valores one-color derivados de } \\
\text { indivíduos da mesma categoria (grupo). Todas as combinações possíveis } \\
\text { são realizadas. }\end{array}$ \\
\hline
\end{tabular}

Sequência típica de eventos

\begin{tabular}{|l|l|}
\hline \multicolumn{1}{|c|}{ Ação do Ator } & \multicolumn{1}{c|}{ Resposta do sistema } \\
\hline $\begin{array}{l}\text { 1. Este caso de uso é iniciado como } \\
\text { resultado da execução do caso de uso } \\
\text { Processar dados. }\end{array}$ & $\begin{array}{l}\text { 2. O sistema identifica todas as } \\
\text { combinações possíveis dos cruzamentos } \\
\text { entre indivíduos de mesma categoria }\end{array}$ \\
\hline & $\begin{array}{l}\text { 3. O sistema calcula a razão entre os } \\
\text { valores derivados dos indivíduos } \\
\text { associados a cada combinação } \\
\text { identificada. }\end{array}$ \\
\hline & $\begin{array}{l}\text { 4. O sistema cria um arquivo que contém } \\
\text { as razões geradas pelos cruzamentos }\end{array}$ \\
\hline
\end{tabular}




\begin{tabular}{|l|l|}
\hline Caso de Uso & $\begin{array}{l}\text { Transformar dados obtidos por abordagens one-color em dados obtidos } \\
\text { por abordagens two-color através do cruzamento entre indivíduos de } \\
\text { grupos distintos - cruzamento intergrupos (Conector) }\end{array}$ \\
\hline Atores & Biologista (indireto) \\
\hline Finalidade & $\begin{array}{l}\text { Transformar dados obtidos por abordagens one-color em dados obtidos } \\
\text { por abordagens two-color realizando o cruzamento de dados de } \\
\text { indivíduos de categorias distintas. }\end{array}$ \\
\hline Visão Geral & $\begin{array}{l}\text { Os dados extraídos do banco de dados NCBI consistem de resultados de } \\
\text { abordagens one-color derivados de indivíduos de diversas categorias. } \\
\text { Esses dados são transformados em dados simulados de abordagens two- } \\
\text { color através do cálculo da razão entre dois valores one-color derivados } \\
\text { de indivíduos de categorias (grupos) distintas. Todas as combinações } \\
\text { possíveis são realizadas. }\end{array}$ \\
\hline
\end{tabular}

Sequência típica de eventos

\begin{tabular}{|l|l|}
\hline \multicolumn{1}{|c|}{ Ação do Ator } & \multicolumn{1}{c|}{ Resposta do sistema } \\
\hline $\begin{array}{l}\text { 1. Este caso de uso é iniciado como } \\
\text { resultado da execução do caso de uso } \\
\text { Processar dados. }\end{array}$ & $\begin{array}{l}\text { 2. O sistema identifica todas as } \\
\text { combinações possíveis dos cruzamentos } \\
\text { entre indivíduos de categorias distintas. }\end{array}$ \\
\hline & $\begin{array}{l}\text { 3. O sistema calcula a razão entre os } \\
\text { valores derivados dos indivíduos } \\
\text { associados a cada combinação } \\
\text { identificada. }\end{array}$ \\
\hline & $\begin{array}{l}\text { 4. O sistema cria um arquivo que contém } \\
\text { as razões geradas pelos cruzamentos } \\
\text { dos dados derivados desses indivíduos. }\end{array}$ \\
\hline
\end{tabular}

\begin{tabular}{|l|l|}
\hline Caso de Uso & Importar dados de arquivos (RGui) \\
\hline Atores & Biologista (iniciador) \\
\hline Finalidade & $\begin{array}{l}\text { Carregar dados contidos em arquivos para que possam ser utilizados } \\
\text { pela ferramenta. }\end{array}$ \\
\hline Visão Geral & $\begin{array}{l}\text { O biologista opta por importar dados contidos em arquivos que estejam } \\
\text { em um dos formatos aceitos pela ferramenta. Esses dados estão contidos } \\
\text { em dois arquivos (cruzamentos intergrupos, cruzamentos intragrupos) e } \\
\text { são carregados para que possam ser utilizados em um teste de hipóteses } \\
\text { pela ferramenta RGui. }\end{array}$ \\
\hline
\end{tabular}

Sequência típica de eventos

\begin{tabular}{|l|c|}
\hline \multicolumn{1}{|c|}{ Ação do Ator } & \multicolumn{1}{c|}{ Resposta do sistema } \\
\hline $\begin{array}{l}\text { 1. Este caso de uso é iniciado quando o } \\
\text { biologista requisita a importação de } \\
\text { dados contidos em arquivos. }\end{array}$ & $\begin{array}{l}\text { 2. O sistema informa os arquivos } \\
\text { existentes em um dado diretório e } \\
\text { requisita a seleção do arquivo desejado. }\end{array}$ \\
\hline $\begin{array}{l}\text { 3. O biologista informa os arquivos que } \\
\text { contém os dados de interesse }\end{array}$ & $\begin{array}{l}\text { 4. Caso os arquivos estejam em um } \\
\text { formato aceito pelo sistema, os dados } \\
\text { contidos nos arquivos são carregados }\end{array}$ \\
\hline \multicolumn{2}{|c|}{140}
\end{tabular}


em matrizes para serem utilizados.

Sequência alternativa de eventos

\begin{tabular}{|l|l|}
\hline \multicolumn{1}{|c|}{ Ação do Ator } & \multicolumn{1}{c|}{ Resposta do sistema } \\
\hline $\begin{array}{l}\text { 1. Este caso de uso é iniciado quando o } \\
\text { biologista requisita a importação de } \\
\text { dados contidos em arquivos. }\end{array}$ & $\begin{array}{l}\text { 2. O sistema informa os arquivos } \\
\text { existentes em um dado diretório e } \\
\text { requisita a seleção do arquivo desejado. }\end{array}$ \\
\hline $\begin{array}{l}\text { 3. O biologista informa os arquivos que } \\
\text { contém os dados de interesse }\end{array}$ & $\begin{array}{l}\text { 4. Caso o arquivo não esteja em um } \\
\text { formato aceito pelo sistema, os dados } \\
\text { contidos no arquivo não são carregados } \\
\text { e uma mensagem de erro é exibida. }\end{array}$ \\
\hline
\end{tabular}

\section{E3.2. Refinamento arquitetônico do cenário de integração}

$\mathrm{O}$ conector $\mathrm{C}_{1}$ é responsável por realizar o caso de uso "Processar dados". Esse conector foi identificado como um conector composto formado por dois conectores simples: $\mathrm{C}_{1.1}$ e $\mathrm{C}_{1.2}$. Cada conector simples é responsável por executar um caso de uso de interesse. $\mathrm{C}_{1.1}$ é responsável pela execução do caso de uso "Transformar dados em dados two-color realizando cruzamento entre indivíduos do mesmo grupo (intragupos)", enquanto que $\mathrm{C}_{1.2}$ é responsável pela execução do caso de uso "Transformar dados em dados two-color realizando cruzamento entre indivíduos de grupos distintos (intergupos)". Após o processamento dos dados é possível utilizar a ferramenta RGui para "Importar e carregar dados em uma matriz". A Figura 50 ilustra a integração do banco de dados à ferramenta RGui através do conector $\mathrm{C}_{1}$ e a decomposição do mesmo em $\mathrm{C}_{1.1}$ e $\mathrm{C}_{1.2}$

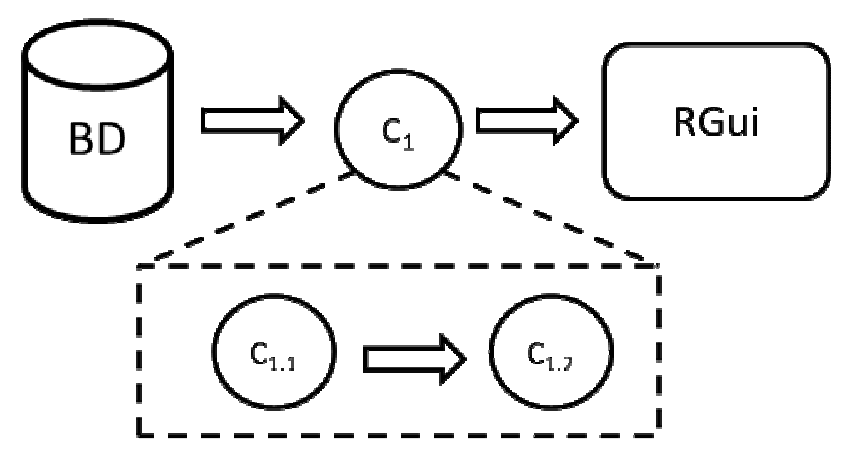

Figura 50: Integração do banco de dados à ferramenta RGui através do conector $C_{1}$

\section{E4. Descrição detalhada dos dados de interesse.}

A descrição detalhada dos dados de interesse (entrada e saída associadas ao conector $\mathrm{C}_{1}$ ) envolve a descrição dos dados extraídos do banco de dados e dos dados associados à ferramenta RGui (funcionalidade $\mathrm{R}_{1}$ ). A Figura 51 ilustra uma representação da integração do 
banco de dados à ferramenta RGui através dos conectores $\mathrm{C}_{1.1}$ e $\mathrm{C}_{1.2}$ que compõem $\mathrm{C}_{1}$. $\mathrm{EC}_{1}$ representa os dados extraídos do banco de dados que servirão de entrada para os conectores $\mathrm{C}_{1.1}$ e $\mathrm{C}_{1.2}$. $\mathrm{SC}_{1.1}$ e $\mathrm{SC}_{1.2}$ representam os dados que serão produzidos pelo conector $\mathrm{C}_{1.1}$ e $\mathrm{C}_{1.2}$, respectivamente, e consumidos pela ferramenta RGui. As descrições detalhadas desses dados estão especificadas para cada conector.

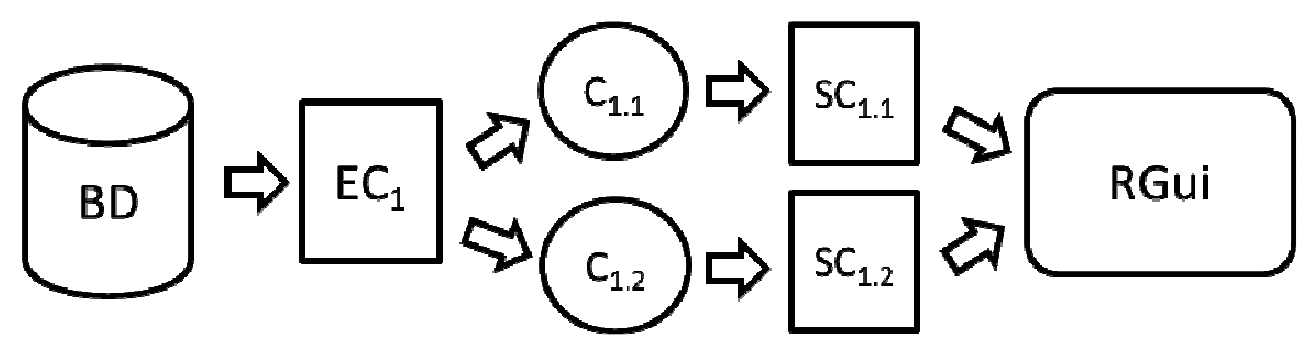

Figura 51: Dados de entrada e saída associados aos conectores $C_{1.1}$ e $C_{1.2}$ (terceiro estudo de caso)

\section{E4.1. Descrição detalhada dos dados de interesse associados a $C_{1.1}$}

$\mathbf{C}_{1.1}$ : Conector responsável por realizar a transformação dos dados para valores obtidos por abordagens two-color realizando cruzamentos entre indivíduos do mesmo grupo (intragrupos).

$\mathbf{E C}_{1}$ : Os dados de entrada do conector $\mathrm{C}_{1.1}$ consistem nos dados extraídos do banco de dados. Esses dados devem estar contidos em arquivos texto com formato delimitado por tabulações. Cada arquivo representa uma condição experimental e contém dados que devem representar genes associados a valores de expressão gênica, resultados da execução de uma abordagem one-color. A Tabela 20 apresenta a descrição desses dados.

Tabela 20: Descrição dos dados de entrada do conector $\mathbf{C}_{\mathbf{1 . 1}}$

\begin{tabular}{|c|c|c|}
\hline Item de dado & Descrição semântica & Sintaxe de representação \\
\hline Identificador de um gene & Dado que representa um identificador de um gene & $\begin{array}{l}\text { Conjunto de valores do tipo String apresentados } \\
\text { na primeira coluua da malriz de dados em uml } \\
\text { arquivo texto delimitado por tabulaçòes }\end{array}$ \\
\hline $\begin{array}{r}\text { Valor de expressão gênica } \\
\text { obtido pela abordagem } \\
\text { one-color }\end{array}$ & $\begin{array}{l}\text { Dado que representa umı valor de expressão gênica } \\
\text { gerado de uma abordagem one-color e associado a } \\
\text { umn gene eml umla condiçăo experimentlal }\end{array}$ & $\begin{array}{l}\text { Conjunto de valures do lipo ponlo lluluarte } \\
\text { apresentados na segunda coluna da matriz de } \\
\text { daclus ein uml arçuivo lexto delirnilado por } \\
\text { tabulações }\end{array}$ \\
\hline Condição experimental & $\begin{array}{l}\text { Dado que descreve a condiçăo experimental yu } \\
\text { qual valores de expressão genes são obtidos }\end{array}$ & $\begin{array}{l}\text { Válor do lipo String representado alravés do } \\
\text { nome do arquivo que contém os dados }\end{array}$ \\
\hline
\end{tabular}

$\mathbf{S C}_{1.1}$ : Os dados de saída do conector $\mathrm{C}_{1.1}$ devem estar contidos em arquivos texto delimitados por tabulações e devem representar valores de expressão gênica associados a diversos genes 
identificados, resultado da execução de abordagens two-color. Esses valores devem ser simulados através da razão entre dois valores derivados de indivíduos do mesmo grupo (condição experimental). A combinação de condições experimentais que os genes foram submetidos para gerar o valor de expressão gênica one-color gera uma nova condição associada aos valores simulados. A Tabela 21 apresenta a descrição desses dados.

Tabela 21: Descrição dos dados de saída do conector $C_{1.1}$ (terceiro estudo de caso)

\begin{tabular}{|r|l|l|}
\hline \multicolumn{1}{|c|}{ Item de dado } & \multicolumn{1}{|c|}{ Descrição semântica } & \multicolumn{1}{|c|}{ Sintaxe de representação } \\
\hline Identificador de um gene & $\begin{array}{l}\text { Dado que representa um identificador de um } \\
\text { gene }\end{array}$ & $\begin{array}{l}\text { Conjunto de valores do tipo String apresentados } \\
\text { na primeira coluna da matriz de dados em um } \\
\text { arquivo tcxto dclimitado por tabulaçôcs }\end{array}$ \\
\hline $\begin{array}{r}\text { Valor de expressão gênica } \\
\text { obtido pela abordagem } \\
\text { two-color }\end{array}$ & $\begin{array}{l}\text { Dado que representa um valor de expressão } \\
\text { gênica associaclo a um gene dada uma condição } \\
\text { experimental, obtido através da razào de valores } \\
\text { de individuos da mesma categoria }\end{array}$ & $\begin{array}{l}\text { Conjunto de valores do tipo ponto flutuante } \\
\text { apresentaclos na matriz de dados em um arquivo } \\
\text { texto delimitado por tabulaçôes }\end{array}$ \\
\hline $\begin{array}{r}\text { Condição } \\
\text { experimental }\end{array}$ & $\begin{array}{l}\text { Dado que descreve a combinação de condições } \\
\text { cxperimentais nas quais os valorcs de cxprcssão } \\
\text { gênica săo obtidos attificialmente }\end{array}$ & $\begin{array}{l}\text { Conjunto de valores do tipo String apresentados } \\
\text { na primcira linha da matriz dc dados cm um } \\
\text { arquivo texto delimitado por tabulaçôes }\end{array}$ \\
\hline
\end{tabular}

\section{E4.2. Descrição detalhada dos dados de interesse associados a $C_{1.2}$}

$\mathbf{C}_{1.2}$ : Conector responsável por realizar a transformação dos dados para valores obtidos por abordagens two-color realizando cruzamentos entre indivíduos de grupos distintos (intergrupos).

$\mathbf{E C}_{1}$ : Os dados de entrada do conector $\mathrm{C}_{1.2}$ são os mesmos de entrada do conector $\mathrm{C}_{1.1} \mathrm{e}$ consistem nos dados extraídos do banco de dados. Esses dados devem estar contidos em arquivos texto com formato delimitado por tabulações. Cada arquivo representa uma condição experimental e contém dados que devem representar genes associados a valores de expressão gênica, resultados da execução de uma abordagem one-color (veja Tabela 20).

$\mathbf{S C}_{1.2}$ : Os dados de saída do conector $\mathrm{C}_{1.2}$ devem estar contidos em arquivos texto delimitados por tabulações e devem representar valores de expressão gênica associados a diversos genes identificados, resultado da execução de abordagens two-color. A descrição desses dados é similar à descrição de $\mathrm{SC}_{1.1}$, contudo os valores devem ser simulados através da razão entre dois valores derivados de indivíduos de grupos distintos (condição experimental). A combinação das condições experimentais, que os genes foram submetidos para gerar o valor de expressão gênica one-color, gera uma nova condição associada aos valores simulados. A Tabela 22 apresenta a descrição desses dados. 
Tabela 22: Descrição dos dados de saída do conector $\mathrm{C}_{1.2}$ (terceiro estudo de caso)

\begin{tabular}{|c|c|c|}
\hline Item de dado & Descrição semântica & Sintaxe de representação \\
\hline Identificador de um gene & $\begin{array}{l}\text { Dado que representa um identificador de um } \\
\text { gene }\end{array}$ & $\begin{array}{l}\text { Conjunto de valores do tipo String apresentados } \\
\text { na primeira coluna da matriz de dados }\end{array}$ \\
\hline $\begin{array}{r}\text { Valor de expressão gênica } \\
\text { obtido pela abordagem } \\
\text { two-color }\end{array}$ & $\begin{array}{l}\text { Dado quc reprcsenta um valor dc cxpressào } \\
\text { gẻnica associada a um gene dada uma condição } \\
\text { experimental, obtido através da razào de valores } \\
\text { de individuos de diferentes categorias }\end{array}$ & $\begin{array}{l}\text { Conjunto dc valorcs do tipo ponto flutuantc } \\
\text { contidos em uma matriz de dados em um arquivo } \\
\text { texto delimitado por tabulaçoses }\end{array}$ \\
\hline $\begin{array}{l}\text { Condição experimental/ } \\
\text { Descritor dos individuos }\end{array}$ & $\begin{array}{l}\text { Dado que descrcve a combinaçào de condiçõcs } \\
\text { experimentais nas quais o valor de expressāo } \\
\text { gênica foi obtido artificialmente }\end{array}$ & $\begin{array}{l}\text { Conjunto de valores do tipo String aprescntados } \\
\text { na primeira linha da matriz de dados }\end{array}$ \\
\hline
\end{tabular}

\section{E5. Modelagem conceitual dos dados de interesse.}

A modelagem conceitual foi realizada separadamente para cada conector simples, $\mathrm{C}_{1.1}$ e $\mathrm{C}_{1.2}$, que forma $\mathrm{C}_{1}$.

\section{E5.1. Modelagem conceitual dos dados de interesse associados a $C_{1.1}$}

A Figura 52 ilustra a modelagem conceitual dos dados de interesse associados à entrada do conector $\mathrm{C}_{1.1}\left(\mathrm{EC}_{1.1}\right)$. Cada arquivo representa dados derivados de um indivíduo submetido a uma dada condição experimental para medição da expressão gênica. Para cada linha do arquivo de entrada existe um identificador de gene que aparece uma única vez em cada arquivo associado a um valor de expressão gênica obtido através da abordagem onecolor.

Dessa forma os seguintes conceitos foram identificados: Gene, que representa um gene cujo valor de expressão gênica foi mensurado; Condicao_Experimental, que representa a condição experimental em que os genes são submetidos para a medição da expressão gênica e Valor_Expressao_Genica, que representa um valor que quantifica o nível que um Gene está expresso através de uma medição relativa, resultado da execução de uma abordagem onecolor.Valor_Expressao_Genica foi modelado como uma classe de associação definida entre Gene e Condicao_Experimental. 


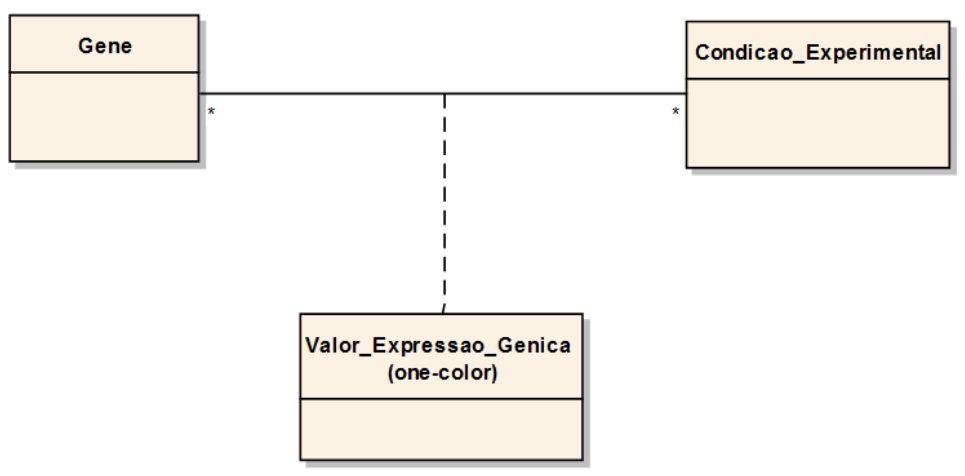

Figura 52: Modelagem conceitual associada à entrada do conector $\mathbf{C}_{1.1}$

A Figura 53 ilustra a modelagem conceitual dos dados associados à saída do conector $\mathrm{C}_{1.1}\left(\mathrm{SC}_{1.1}\right)$. Esse conector realiza o serviço de transformação dos dados obtidos por abordagens one-color em dados obtidos por abordagens two-color a partir do cruzamento de dados derivados de indivíduos do mesmo grupo/condição experimental. A partir da descrição detalhada dos dados de interesse é possível identificar genes, condições experimentais e valores de expressão gênica. Para cada associação de um gene com uma condição experimental existe um valor de expressão gênica two-color.

Os seguintes conceitos foram identificados: Gene, que representa um gene cujo valor de expressão gênica foi mensurado; Condicao_Experimental, que representa a condição experimental em que os genes são submetidos para a medição da expressão gênica e Valor_Expressao_Genica, que representa um valor que quantifica o nível que um Gene está expresso através de uma medição relativa. Valor_Expressao_Genica foi modelado como uma classe de associação definida entre Gene e Condicao_Experimental e, além disso, é resultado de combinações de dados derivados de indivíduos do mesmo grupo obtidos de abordagens one-color. Dessa forma, dados de expressão gênica de abordagens two-color são simulados.

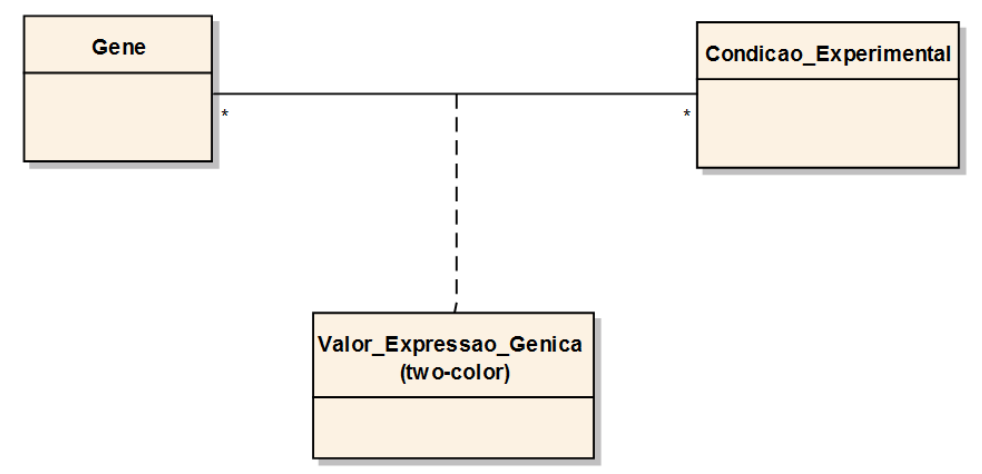

Figura 53: Modelagem conceitual associada à saída do conector $\mathbf{C}_{1.1}$ 


\section{E5.2. Modelagem conceitual dos dados de interesse associados a $C_{1.2}$}

A modelagem conceitual dos dados de interesse associados à entrada do conector $\mathrm{C}_{1.2}$ $\left(\mathrm{EC}_{1.2}\right)$ é idêntica à modelagem conceitual dos dados associados à entrada do conector $\mathrm{C}_{1.1}$ $\left(\mathrm{EC}_{1.1}\right)$ (veja Figura 52). Cada arquivo representa dados derivados de um indivíduo submetido a uma dada condição experimental para medição da expressão gênica. Para cada linha do arquivo de entrada existe um identificador de gene que aparece uma única vez em cada arquivo associado a um valor de expressão gênica obtido através da abordagem one-color.

A modelagem conceitual dos dados associados à saída do conector $\mathrm{C}_{1.2}\left(\mathrm{SC}_{1.2}\right)$ é idêntica à modelagem conceitual dos dados associados à saída do conector $\mathrm{C}_{1.1}\left(\mathrm{SC}_{1.1}\right)$ (veja Figura 53). Apesar do conector $\mathrm{C}_{1.2}$ realizar o serviço de transformação dos dados obtidos por abordagens one-color em dados two-color a partir do cruzamento de dados derivados de indivíduos de diferentes grupos/condições experimentais, não há necessidade de realizar nenhuma modificação na modelagem conceitual dos dados de saída do conector $\mathrm{C}_{1.1}\left(\mathrm{SC}_{1.1}\right)$.

\section{E6. Mapeamento para ontologia de referência.}

O mapeamento para ontologia de referência foi realizado separadamente para cada conector simples, $\mathrm{C}_{1.1}$ e $\mathrm{C}_{1.2}$, que forma $\mathrm{C}_{1}$.

\section{E6.1. Mapeamento para ontologia de referência associado ao conector $C_{1.1}$}

A Tabela 23 apresenta o mapeamento entre os conceitos associados à entrada e à saída do conector $\mathrm{C}_{1.1}$ aos conceitos da ontologia de referência.

Tabela 23: Mapeamento dos conceitos associados à entrada e à saída do conector a conceitos da ontologia de referência

\begin{tabular}{|c|c|c|}
\hline $\begin{array}{c}\text { Conceito entrada } \\
\text { conector }\end{array}$ & $\begin{array}{c}\text { Conceito ontologia } \\
\text { referência }\end{array}$ & $\begin{array}{c}\text { Conceito saída } \\
\text { conector }\end{array}$ \\
\hline Gene & Gene & Gene \\
\hline Condicao_Experimental & Experimental_Condition & Condicao_Experimental \\
\hline $\begin{array}{c}\text { Valor_Expressao_Genica } \\
\text { (one-color) }\end{array}$ & Intensity_Based_Value & \\
\hline & Ratio_Based_Value & $\begin{array}{c}\text { Valor_Expressao_Genica } \\
\text { (two-color) }\end{array}$ \\
\hline
\end{tabular}


Neste mapeamento todos os conceitos estão corretamente associados a seus respectivos conceitos da ontologia de referência, mas alguns não estão associados a seus respectivos dados de entrada ou saída do conector. $\mathrm{O}$ conceito de entrada Valor_Expressao_Genica (one-color) que está associado ao conceito Intensity_Based_Value não possui nenhum conceito associado à saída do conector e o conceito de saída Valor_Expressao_Genica (two-color) que está associado ao conceito Ratio_Based_Value também não possui nenhum conceito associado à entrada do conector.

Essa falta de associação é justificada pela transformação dos dados de entrada do conector que representam Valor_Expressao_Genica obtidos pela abordagem one-color em Valor_Expressao_Genica obtidos pela abordagem two-color. O conector responsável por essa transformação realiza todos os possíveis cruzamentos entre os indivíduos do mesmo grupo. Dessa forma é possível obter Valor_Expressao_Genica (associado a Ratio_Based_Value) através da adequação de Valor_Expressao_Genica (associado a Intensity_Based_Value). Essa adequação consiste na razão entre dois valores one-color associados a um mesmo gene e derivados de diferentes indivíduos de categoria/condição comum, gerando artificialmente um valor two-color de um gene.

A Tabela 24 apresenta o mapeamento dos conceitos associados à entrada e à saída do conector $\mathrm{C}_{1.1}$ a conceitos da ontologia. Para essa situação não foi necessário inserir novos conceitos na ontologia de referência, mas é necessária uma transformação semântica dos dados para tornar possível a associação entre conceitos distintos associados à entrada e à saída do conector e assim possibilitar um mapeamento completo de todos os conceitos.

Tabela 24: Mapeamento revisado dos conceitos associados à entrada e à saída do conector a conceitos da ontologia de referência

\begin{tabular}{|c|c|c|}
\hline $\begin{array}{c}\text { Conceito entrada } \\
\text { conector }\end{array}$ & $\begin{array}{c}\text { Conceito ontologia } \\
\text { referência }\end{array}$ & $\begin{array}{c}\text { Conceito saída } \\
\text { conector }\end{array}$ \\
\hline Gene & Gene & Gene \\
\hline Condicao_Experimental & Experimental_Condition & Condicao_Experimental \\
\hline $\begin{array}{c}\text { Valor_Expressao_Genica } \\
\text { (one-color) }\end{array}$ & Ratio_Based_Value & $\begin{array}{c}\text { Valor_Expressao_Genica } \\
\text { (two-color) }\end{array}$ \\
\hline
\end{tabular}




\section{E6.2. Mapeamento para ontologia de referência associado ao conector $C_{1.2}$}

$\mathrm{O}$ mapeamento entre os conceitos associados à entrada e à saída do conector $\mathrm{C}_{1.2}$ aos conceitos da ontologia de referência é igual ao mapeamento do conector $\mathrm{C}_{1.1}$ (veja Tabela 23). De forma análoga, os dados de entrada do conector que representam Valor_Expressao_Genica obtido pela abordagem one-color devem ser transformados para Valor_Expressao_Genica obtido pela abordagem two-color. A diferença está que o conector responsável por essa transformação deve realizar o cruzamento entre indivíduos de grupos/condições distintos. Dessa forma, Valor_Expressao_Genica obtido pela abordagem two-color podem ser obtidos a partir de combinações de Valor_Expressao_Genica obtidos pela abordagem one-color.

$\mathrm{O}$ mapeamento revisado dos conceitos associados à entrada e à saída do conector $\mathrm{C}_{1.2}$ é o mesmo associado ao conector $\mathrm{C}_{1.1}$ (veja Tabela 24$)$.

\section{E7. Adequação dos dados de interesse}

As adequações sintáticas e semânticas que devem ser realizadas foram definidas separadamente para cada conector simples, $\mathrm{C}_{1.1}$ e $\mathrm{C}_{1.2}$, que forma $\mathrm{C}_{1}$.

\section{E7.1. Adequação dos dados de interesse associados ao conector $C_{1.1}$}

Os dados de entrada inicial consistem de arquivos texto cujos dados estão separados por tabulações. Cada arquivo contém dados associados a um indivíduo que foram obtidos de acordo com uma condição experimental, o que confere uma característica diferenciada. Esses dados informam os valores de expressão gênica de genes identificados. Contudo, existem informações consideradas irrelevantes nesses arquivos que devem ser filtradas. Dessa forma a adequação sintática consiste de duas etapas. A primeira para extrair apenas os dados de interesse dos arquivos que consistem nos identificadores de genes e seus respectivos valores de expressão gênica. A segunda etapa consiste na conversão dos dados extraídos em dados numéricos e textuais.

A adequação semântica consiste na transformação dos dados numéricos e textuais em dados one-color. Posteriormente esses dados são transformados em dados two-color. Para possibilitar a transformação de valores one-color em two-color é necessário realizar o cruzamento entre indivíduos de mesma categoria/condição. Cada grupo de indivíduo possui uma característica comum e deve possuir mais de um representante. $\mathrm{O}$ cruzamento consiste 
em dividir o valor de expressão gênica associado a um gene em um arquivo pelo valor de expressão gênica associado ao mesmo gene em outros arquivos e assim gerar um novo arquivo com os resultados desses cruzamentos $[95,96]$. Cada arquivo representa dados de um indivíduo associado a uma condição experimental.

\section{E7.2. Adequação dos dados de interesse associados ao conector $C_{1.2}$}

A adequação sintática dos dados de interesse associados ao conector $\mathrm{C}_{1.2}$ é a mesma associada ao conector $\mathrm{C}_{1.1}$. Essa adequação é realizada em duas etapas: a primeira etapa consiste na extração dos dados de interesse dos arquivos, isto é, identificadores de genes e seus respectivos valores de expressão gênica; a segunda etapa consiste na conversão dos dados extraídos em dados numéricos e textuais.

A adequação semântica também é similar a adequação realizada pelo conector $\mathrm{C}_{1.1} \mathrm{e}$ consiste na transformação dos dados numéricos e textuais em dados obtidos por abordagens one-color. Posteriormente esses dados são transformados em dados correspondentes a dados obtidos por uma abordagem two-color. Contudo, o conector $\mathrm{C}_{1.2}$ realiza cruzamentos entre indivíduos de grupos distintos e assim gera um novo arquivo com todos os valores resultantes desses cruzamentos.

\section{E8. Identificação de políticas de acesso e ativação.}

A ferramenta RGui disponibiliza acesso local às suas funcionalidades e pode ser instalada em qualquer diretório. Não existem restrições de acesso a essa ferramenta. A transferência de controle pode ser manual ou automática a partir da execução do conector.

\section{E9. Implementação do conector.}

A Figura 54 ilustra o diagrama de classes UML dos conectores simples identificados. Todas as classes foram implementadas utilizando a linguagem de programação Java. 


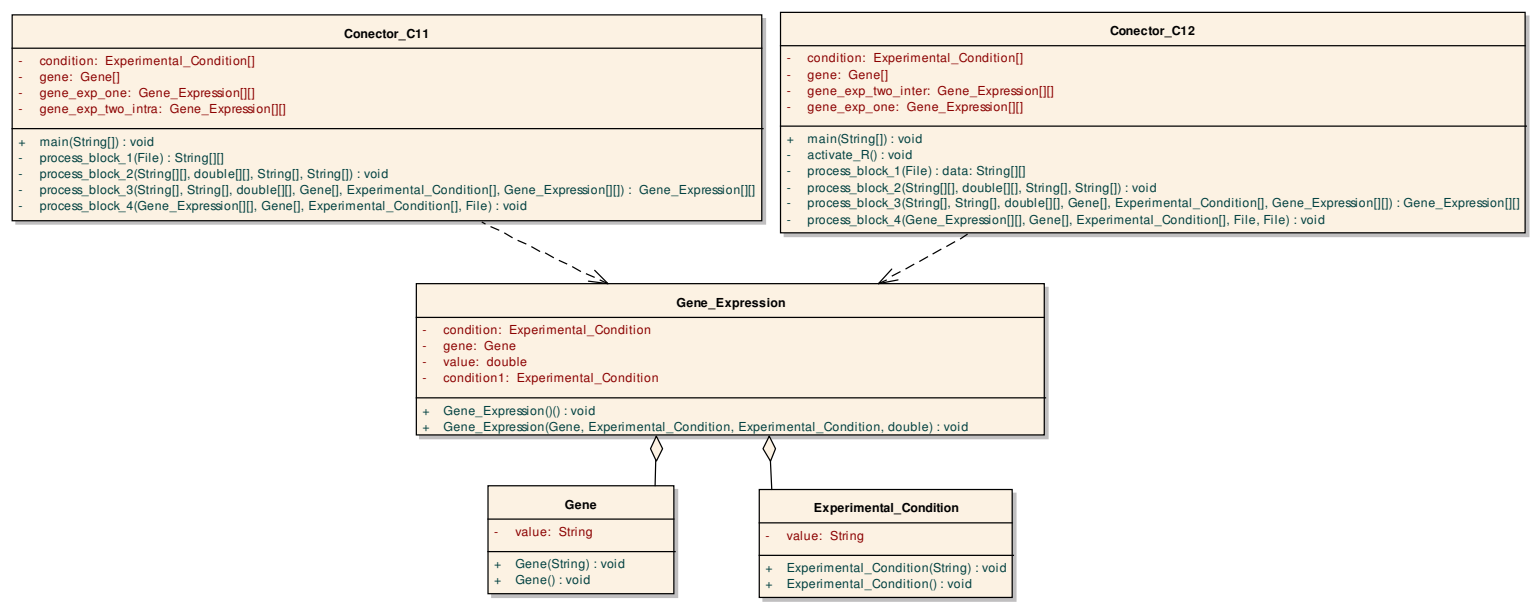

Figura 54: Diagrama de classes dos conectores simples

As classes Experimental_Condition, Gene e Gene_Expression foram criadas a partir dos conceitos identificados nos modelos conceituais. Gene é uma classe para representação de genes e, neste caso armazena o identificador do gene. Essa classe possui associada uma ou mais sequências de bases nitrogenadas. Experimental_Condition é uma classe para representação de condições experimentais nas quais os genes são submetidos para medição da expressão gênica. Gene_Expression é uma classe de associação para representação de valores de expressão gênica, cada um associado a um gene e uma condição experimental. Esse valor de expressão gênica está associado a um gene e pode ser obtido por abordagem one-color e, portanto, apresenta apenas uma condição experimental associada, ou pode ser gerado artificialmente pela razão de dois valores obtidos por abordagens one-color e possui duas condições experimentais associadas na geração desse valor.

As classes Conector_C11 e Conector_C12 representam os conectores simples $\mathrm{C}_{1.1} \mathrm{e}$ $\mathrm{C}_{1.2}$, respectivamente. Cada conector simples foi modelado e implementado como uma aplicação Java. Dessa forma, cada conector pode ser (re)utilizado e executado independentemente dos demais conectores. A classe Conector_C1 (não representada no diagrama da Figura 54) representa o conector composto C1. Esta classe é responsável pela composição e execução individual de cada um dos conectores simples.

Os conectores $\mathrm{C}_{1.1}$ e $\mathrm{C}_{1.2}$ são executados sequencialmente e nesta ordem. Somente após o término da execução de um conector, outro conector é executado. Cada conector é executado como um processo independente e dessa forma possui uma thread de controle responsável pela execução de seus blocos funcionais, implementados como métodos de suas 
respectivas classes. Estes blocos também são executados de forma sequencial, de modo que um bloco é executado somente após o término da execução do bloco anterior.

O primeiro conector, $\mathrm{C}_{1.1}$, é responsável por transformar dados obtidos por abordagens one-color em dados obtidos por abordagens two-color através do cruzamento de indivíduos do mesmo grupo - cruzamento intragrupos. O método main recebe como parâmetros o identificador do diretório que contém os arquivos com os dados de entrada e o identificador do diretório onde serão armazenados os dados de saída desse conector. Os dados de entrada desse conector consistem de arquivos contidos em um diretório informado pelo usuário cujos dados representam genes e seus respectivos valores de expressão gênica gerados a partir de abordagem one-color. Os dados de saída consistem de arquivos cujos dados representam genes e seus respectivos valores de expressão gênica gerados a partir de abordagem twocolor. Os atributos dessa classe consistem de um vetor de condições experimentais (Experimental_Condition), um vetor de genes (Gene) e duas matrizes de dados de expressão gênica (Gene_Expression).

O método process_block1 realiza o processamento inicial dos dados através do preenchimento da matriz com os dados contidos nos arquivos do diretório escolhido. Esse método recebe como parâmetro um identificador de arquivo (File) do diretório informado pelo usuário e retorna uma matriz de String para armazenar os dados contidos nos arquivos desse diretório.

O método process_block2 realiza a transformação sintática dos dados contidos nesses arquivos (veja seção E7.1), a qual está dividida em três etapas. A primeira etapa consiste em extrair a partir das informações contidas nos arquivos apenas aquelas de interesse (valor de expressão gênica e o identificador do gene). A segunda etapa consiste em agregar esses dados derivados de diferentes matrizes, uma para cada arquivo, em uma única matriz de String. Dessa forma, cada coluna dessa matriz irá conter informações sobre cada um dos arquivos iniciais. A terceira etapa consiste em transformar os dados extraídos contidos nessa matriz de String em dados numéricos e textuais de acordo com a informação que representam. O método process_block2 recebe como parâmetros uma matriz de String preenchida no método process_block1, uma matriz de double, que armazena os valores contidos no conteúdo da matriz, e dois vetores de String que armazenam os valores do cabeçalho contidos na primeira linha e na primeira coluna da matriz. 
O método process_block3 realiza a transformação semântica dos dados (veja seção E7.1) através da transformação das estruturas de dados definidas e instanciadas em process_block2 em instâncias das classes criadas a partir da modelagem conceitual (associação semântica). Esse método recebe como parâmetros dois vetores de String e uma matriz de double instanciados em process_block2, um vetor de genes (Gene), um vetor de condições experimentais (Experimental_Condition) e uma matriz de dados de expressão gênica (Gene_Expression). Dessa forma, os valores contidos nos vetores de String serão transformados em valores de condições experimentais (Experimental_Condition) e genes (Gene), já os valores contidos na matriz de double serão transformados em valores de expressão gênica (Gene_Expression).

Adicionalmente, a adequação semântica envolve também a transformação desses dados que representam valores de expressão gênica (Gene_Expression) obtidos por abordagem one-color em dados que representam valores de expressão gênica (Gene_Expression) obtidos por abordagem two-color. Essa transformação é feita através do cruzamento entre indivíduos de mesmo grupo/condição experimental e dessa forma, é possível calcular as razões entre dois valores de expressão gênica referentes a um mesmo gene de uma abordagem one-color para gerar artificialmente um valor de expressão gênica two-color. Os valores two-color são armazenados em uma matriz de dados de expressão gênica (Gene_Expression) e retornada no método process_block3.

O método process_block4 realiza o processamento dos dados de saída do conector. Esse método recebe como parâmetros vetores de genes (Gene), condições experimentais (Experimental_Condition) e uma matriz de dados de expressão gênica (Gene_Expression) que representam os dados que serão armazenados em um novo arquivo. Além disso, esse método recebe como parâmetro um identificador de arquivo (File) representando o diretório onde o arquivo será criado.

$\mathrm{O}$ segundo conector, $\mathrm{C}_{1.2}$, é responsável por transformar dados obtidos por abordagens one-color em dados obtidos por abordagens two-color através do cruzamento de indivíduos de grupos distintos - cruzamento intergrupos. O método main recebe como parâmetros o identificador do diretório que contém os arquivos com os dados de entrada e o identificador do diretório onde serão armazenados os dados de saída desse conector. Os dados de entrada desse conector consistem de arquivos cujos dados representam genes e seus respectivos valores de expressão gênica gerados a partir de abordagem one-color e estão contidos em um 
diretório informado pelo usuário. Os dados de saída consistem de arquivos cujos dados representam genes e seus respectivos valores de expressão gênica gerados a partir de abordagem two-color. Os atributos dessa classe consistem de um vetor de Experimental_ Condition, um vetor de Gene e duas matrizes de Gene_Expression.

Os métodos são iguais ao do conector Conector_C11 com a distinção no método process_block3 que realiza o cruzamento entre indivíduos de diferentes grupos/condição experimental e no método process_block4 que realiza a ativação automática da ferramenta RGui e possui um parâmetro a mais, um identificador de arquivo (File) representando o arquivo de ativação da ferramenta. A ativação automática é implementada através da função activate_RGui e realiza a transferência de controle (passagem da thread de execução) para uma instância de RGui executada em uma máquina virtual Java. Para realizar essa ativação são utilizados métodos disponíveis na classe Rengine. 


\section{APÊNDICE F - Desenvolvimento do conector responsável pela integração das ferramentas RGui e DAVID - Terceiro estudo de caso.}

$\mathrm{O}$ conector $\mathrm{C}_{2}$ é o responsável pela integração das ferramentas RGui e DAVID. A linguagem $\mathrm{R}$ é utilizada, em geral, como ferramenta para realizar análise exploratória de dados, cálculos estatísticos e gráficos. RGui é uma interface gráfica que possibilita a utilização dessa linguagem. DAVID é uma ferramenta que disponibiliza bases de dados biológicos integradas a ferramentas da área de bioinformática cujo objetivo é fornecer informações biológicas a partir de uma lista de genes ou proteínas derivados de estudos/experimentos genômicos.

\section{F1. Identificação das principais funcionalidades das ferramentas envolvidas}

Listagem funcional da ferramenta RGui:

O Apêndice A (seção A1) apresentada a listagem funcional desta ferramenta.

Listagem funcional da ferramenta DAVID:

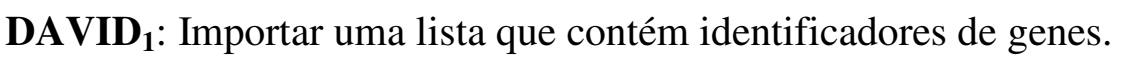

DAVID $_{2}$ : Identificar termos biológicos utilizando Gene Ontology.

DAVID $_{3}$ : Agrupar genes a partir da função.

DAVID $_{4}$ : Clusterizar anotações de termos redundantes.

DAVID 5 : Visualizar genes em ferramentas BioCarta e KEGG Pathway.

DAVID 6 : Exibir resultados em tela de visualização de duas dimensões.

DAVID 7 : Procurar genes funcionalmente relacionados que não estão contidos na lista de entrada.

DAVID $_{8}$ : Listar proteínas interagentes.

DAVID 9: Explorar listas de proteínas interagentes.

DAVID $_{10}$ : Explorar um conjunto de genes.

DAVID $_{11}$ : Associar genes a doenças.

DAVID $12_{12}$ Destacar domínios e motivos de proteínas funcionais.

DAVID 13: Redirecionar para referências bibliográficas disponíveis na literatura relacionadas ao estudo. 
DAVID $_{14}$ : Converter identificadores de genes de um tipo para outro, especificado em outra ferramenta.

\section{F2. Descrição inicial do cenário de integração}

Subconjunto de funcionalidades diretamente relacionadas ao cenário de integração:

$\mathbf{R}_{\mathbf{1}}$ : Importar dados. Esses dados devem estar contidos em arquivo cujo formato é aceito por esta ferramenta. Os dados importados são carregados pela mesma.

$\mathbf{R}_{5}$ : Exportar dados em arquivo. $\mathrm{O}$ formato desse arquivo deve ser especificado pelo usuário.

$\mathbf{R}_{12}$ : Aplicar função para realizar teste de hipóteses: "teste t"

DAVID 1 : Importar uma lista que contém identificadores de genes.

DAVID $_{3}$ : Agrupar genes a partir de sua função.

DAVID : Exibir resultados em tela de visualização de duas dimensões.

O cenário envolve a integração de serviços providos pela ferramenta RGui e a ferramenta DAVID. A ferramenta RGui é utilizada para realizar testes de hipóteses. A ferramenta DAVID é utilizada para investigar se existe relacionamento funcional entre os genes contidos em uma lista utilizada como entrada dessa ferramenta.

Os dados utilizados em testes de hipóteses devem consistir de valores produzidos a partir da execução de abordagens microarray two-color para gerar resultados estatisticamente significantes. Dessa forma, é possível realizar uma análise estatística coerente do resultado da aplicação de testes de hipóteses (teste t) nos dados.

Inicialmente o usuário do ambiente integrado da linguagem R (RGui) importa os dados contidos em dois arquivos gerados pelo conector $\mathrm{C}_{1}$, os quais contém dados de expressão gênica equivalentes a dados obtidos por uma abordagem two-color. Esses dados são carregados em matrizes e disponibilizados para uso $\left(\mathbf{R}_{\mathbf{1}}\right)$. Em seguida o usuário aplica um teste de hipóteses nesses dados utilizando uma função de teste t disponível em RGui ( $\left.\mathbf{R}_{\mathbf{1 2}}\right)$. Como resultado RGui gera uma lista de genes com os valores resultantes do teste $\mathrm{t}$ e respectivos p-values. Finalmente, o usuário exporta os dados resultantes em um arquivo texto com formato delimitado por tabulações $\left(\mathbf{R}_{\mathbf{5}}\right)$.

Após a realização do teste de hipótese (teste t), o arquivo gerado por RGui deve ser processado (transformado e validado) para que possa ser aceito pela ferramenta DAVID. O usuário deve informar valores de teste t e $p$-value para serem utilizados como critério para 
seleção de genes. Dessa forma apenas os genes que possuem valores menores que os informados são selecionados. Caso o usuário opte por não definir esses valores apenas $p$-value é utilizado como critério de seleção, com valor padrão de 0,01. O usuário da ferramenta DAVID importa dados representados em uma lista que contém identificadores de genes (DAVID ${ }_{1}$ ). Com os dados carregados, DAVID exibe os mesmos em uma interface de visualização (DAVID $)_{6}$. Finalmente o usuário escolhe uma função para realizar agrupamentos

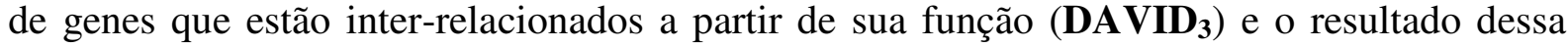
atividade é exibido (DAVID $)_{6}$.

\section{F3. Descrição detalhada do cenário de integração}

A Figura 55 ilustra o diagrama de atividades elaborado a partir da descrição inicial do cenário de integração. As atividades "Importação de dados contidos em um arquivo", “Aplicação de teste de hipóteses" e "Exportação dos dados resultantes em arquivo" são realizadas pela ferramenta RGui. A atividade "Filtragem de dados" é realizada pelo conector, enquanto que as atividades "Importação de uma lista de identificadores de genes", "Agrupamento de genes a partir da função" e "Exibição do agrupamento de genes" são realizadas pela ferramenta DAVID.

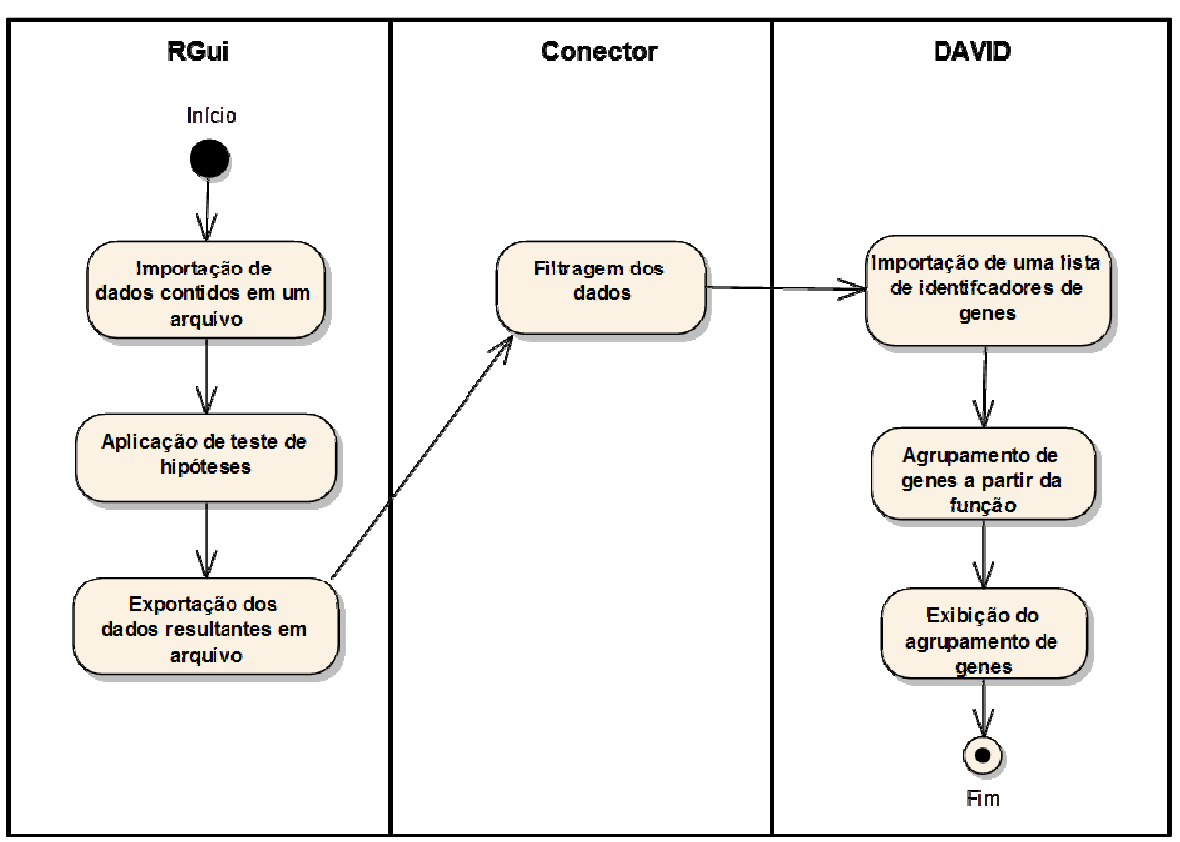

Figura 55: Diagrama de atividades relacionado ao desenvolvimento do conector $C_{2}$ (terceiro estudo de caso) 
A Figura 56 ilustra os casos de uso derivados do diagrama de atividades. Os casos de uso "Importar e carregar dados em uma matriz", "Aplicar teste de hipóteses nos dados" e "Exportar dados em arquivo" estão associados à ferramenta RGui. Os casos de uso "Processar dados" e "Filtrar dados" estão associados ao conector, enquanto que os casos de uso "Importar lista de identificadores de genes", "Agrupar genes a partir de sua função" e "Exibir resultado do agrupamento" estão associados à ferramenta DAVID. Os casos de uso de interesse foram identificados em cinza. A descrição detalhada desses casos de uso é apresentada na seção F3.1.

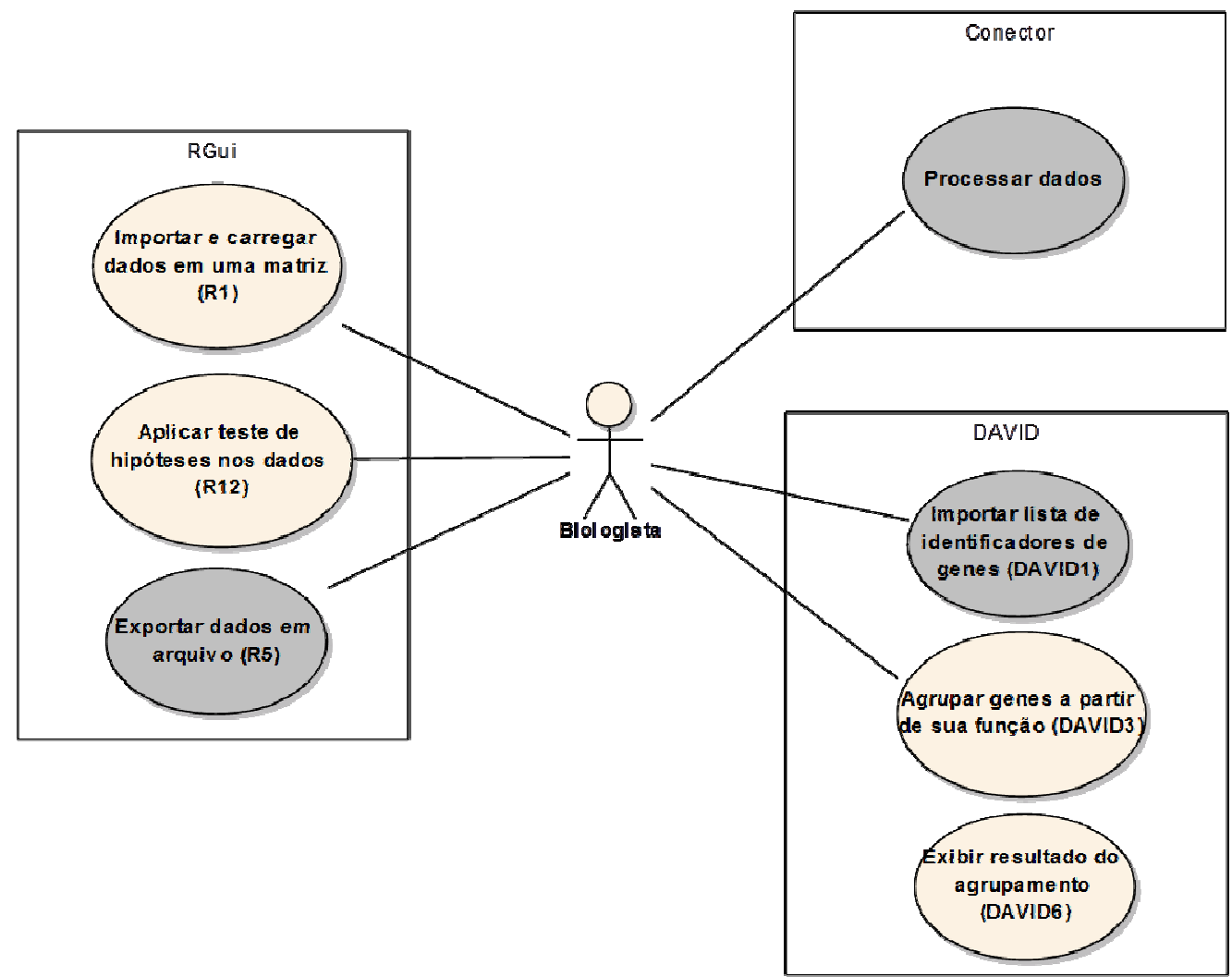

Figura 56: Diagrama de casos de uso relacionado ao desenvolvimento do conector $\mathrm{C}_{2}$ (terceiro estudo de caso)

\section{F3.1. Casos de uso expandido}

\begin{tabular}{|l|l|}
\hline Caso de Uso & Exportar dados em arquivo (DMV) \\
\hline Atores & Biologista (iniciador) \\
\hline Finalidade & $\begin{array}{l}\text { Exportar dados resultado do teste de hipóteses em um arquivo texto com } \\
\text { formato delimitado por tabulações. }\end{array}$ \\
\hline
\end{tabular}




\begin{tabular}{|l|l|}
\hline Visão Geral & $\begin{array}{l}\text { Após a aplicação de uma função de teste de hipóteses (teste t) o } \\
\text { biologista opta por exportar esses dados em um arquivo. O biologista } \\
\text { deve definir o nome do arquivo e o diretório onde o mesmo será } \\
\text { gravado. Por fim, o arquivo é gerado. }\end{array}$ \\
\hline
\end{tabular}
Sequência típica de eventos

\begin{tabular}{|l|l|}
\hline \multicolumn{1}{|c|}{ Ação do Ator } & \multicolumn{1}{c|}{ Resposta do sistema } \\
\hline $\begin{array}{l}\text { 1. Este caso de uso é iniciado quando o } \\
\text { biologista requisita a exportação de } \\
\text { dados gerado como resultado do teste de } \\
\text { hipóteses. }\end{array}$ & $\begin{array}{l}\text { 2. O sistema requisita nome do arquivo e } \\
\text { o diretório onde o mesmo será } \\
\text { armazenado. }\end{array}$ \\
\hline $\begin{array}{l}\text { 3. O biologista informa o nome e o } \\
\text { diretório de armazenamento do arquivo. }\end{array}$ & $\begin{array}{l}\text { 4. O sistema cria um arquivo texto com } \\
\text { formato delimitado por tabulações no } \\
\text { diretório especificado contendo os } \\
\text { dados gerados. }\end{array}$ \\
\hline
\end{tabular}

\begin{tabular}{|l|l|}
\hline Caso de Uso & Processar dados (Conector) \\
\hline Atores & Biologista (iniciador) \\
\hline Finalidade & $\begin{array}{l}\text { Recuperar e filtrar dados obtidos como resultado do teste de hipótese de } \\
\text { modo a serem utilizados pela ferramenta DAVID }\end{array}$ \\
\hline Visão Geral & $\begin{array}{l}\text { O biologista opta por realizar o processamento dos dados através do } \\
\text { conector responsável por transformar os dados objetivando a integração } \\
\text { das ferramentas RGui e DAVID. Neste caso o processamento envolve a } \\
\text { filtragem dos dados. }\end{array}$ \\
\hline
\end{tabular}

Sequência típica de eventos

\begin{tabular}{|c|c|}
\hline Ação do Ator & Ação do sistema \\
\hline $\begin{array}{l}\text { 1. Este caso de uso é iniciado quando o } \\
\text { biologista informa a localização do } \\
\text { arquivo contendo os dados de entrada e } \\
\text { o diretório esperado de armazenamento } \\
\text { dos dados de saída e requisita a filtragem } \\
\text { dos dados para possibilitar a integração } \\
\text { das ferramentas RGui e DAVID. O } \\
\text { biologista informa também o valor de } \\
\text { teste t e/ou p-value para serem utilizados } \\
\text { como critério de seleção dos dados. }\end{array}$ & $\begin{array}{l}\text { 2. O sistema realiza a filtragem que } \\
\text { consiste na seleção dos valores que } \\
\text { possuem um determinado critério } \\
\text { estabelecido pelo usuário. Esses } \\
\text { critérios estão relacionados aos valores } \\
\text { de teste t e } p \text {-value. }\end{array}$ \\
\hline & $\begin{array}{l}\text { 3. O sistema cria um novo arquivo que } \\
\text { contém apenas os genes com o critério } \\
\text { de seleção determinado. }\end{array}$ \\
\hline
\end{tabular}

Sequência alternativa de eventos

\begin{tabular}{|c|c|}
\hline Ação do Ator & Resposta do sistema \\
\hline $\begin{array}{l}\text { 1. Este caso de uso é iniciado quando o } \\
\text { biologista informa a localização do } \\
\text { arquivo contendo os dados de entrada e } \\
\text { o diretório esperado de armazenamento } \\
\text { dos dados de saída e requisita a filtragem }\end{array}$ & $\begin{array}{l}\text { 2. O sistema realiza a filtragem que } \\
\text { consiste na seleção dos valores que } \\
\text { possuem um determinado critério } \\
\text { estabelecido pelo usuário. Esses } \\
\text { critérios estão relacionados aos valores }\end{array}$ \\
\hline
\end{tabular}




\begin{tabular}{|l|l|}
\hline $\begin{array}{l}\text { dos dados para possibilitar a integração } \\
\text { das ferramentas RGui e DAVID. O } \\
\text { biologista não informa nenhum valor } \\
\text { como critério de filtragem }\end{array}$ & de teste t e $p$-value. \\
\hline & $\begin{array}{l}\text { 3. O sistema cria um novo arquivo que } \\
\text { contém apenas os genes cujo } p \text {-value } \\
\text { associado é menor que } 0,01 \text { (valor } \\
\text { padrão) }\end{array}$ \\
\hline
\end{tabular}

\begin{tabular}{|l|l|}
\hline Caso de Uso & Importar lista de identificadores de genes (DAVID) \\
\hline Atores & Biologista (iniciador) \\
\hline Finalidade & $\begin{array}{l}\text { Carregar dados contidos em um arquivo que contém uma lista de genes } \\
\text { para que possam ser manipulados pela ferramenta. }\end{array}$ \\
\hline Visão Geral & $\begin{array}{l}\text { O biologista opta por importar dados contidos em um arquivo que } \\
\text { estejam em um dos formatos aceito pela ferramenta DAVID. Esses } \\
\text { dados devem estar devidamente filtrados para que possam ser realizados } \\
\text { agrupamentos pela ferramenta. }\end{array}$ \\
\hline
\end{tabular}

Sequência típica de eventos

\begin{tabular}{|l|l|}
\hline \multicolumn{1}{|c|}{ Ação do Ator } & \multicolumn{1}{c|}{ Resposta do sistema } \\
\hline $\begin{array}{l}\text { 1. Este caso de uso é iniciado quando o } \\
\text { biologista requisita a importação de } \\
\text { dados contidos em um arquivo. }\end{array}$ & $\begin{array}{l}\text { 2. O sistema informa os arquivos } \\
\text { existentes em um dado diretório e } \\
\text { requisita a seleção do arquivo desejado. }\end{array}$ \\
\hline $\begin{array}{l}\text { 3. O biologista informa o arquivo que } \\
\text { contém os dados de interesse. }\end{array}$ & $\begin{array}{l}\text { 4. Caso o arquivo esteja em um formato } \\
\text { aceito pelo sistema, os dados contidos } \\
\text { no arquivo são carregados de modo que } \\
\text { os mesmos possam ser agrupados. }\end{array}$ \\
\hline
\end{tabular}

Sequência alternativa de eventos

\begin{tabular}{|l|l|}
\hline \multicolumn{1}{|c|}{ Ação do Ator } & \multicolumn{1}{c|}{ Resposta do sistema } \\
\hline $\begin{array}{l}\text { 1. Este caso de uso é iniciado quando o } \\
\text { biologista requisita a importação de } \\
\text { dados contidos em um arquivo. }\end{array}$ & $\begin{array}{l}\text { 2. O sistema informa os arquivos } \\
\text { existentes em um dado diretório e } \\
\text { requisita a seleção do arquivo desejado. }\end{array}$ \\
\hline $\begin{array}{l}\text { 3. O biologista informa o arquivo que } \\
\text { contém os dados de interesse. }\end{array}$ & $\begin{array}{l}\text { 4. Caso o arquivo não esteja em um } \\
\text { formato aceito pelo sistema, os dados } \\
\text { contidos no arquivo não são carregados } \\
\text { e uma mensagem de erro é exibida. }\end{array}$ \\
\hline
\end{tabular}

\section{F4. Descrição detalhada dos dados de interesse.}

A Figura 57 ilustra uma representação da integração das ferramentas RGui e DAVID através do conector $\mathrm{C}_{2}$. A ferramenta RGui gera os dados que servirão de entrada para o conector $\mathrm{C}_{2}\left(\mathrm{EC}_{2}\right)$, enquanto que a ferramenta DAVID consome os dados que serão produzidos pelo mesmo $\left(\mathrm{SC}_{2}\right)$. A descrição detalhada dos dados de interesse (entrada e saída 
associadas ao conector) está relacionada às funcionalidades $\mathrm{R}_{5}$ e $\mathrm{DAVID} \mathrm{D}_{1}$ das ferramentas RGui e DAVID, respectivamente.

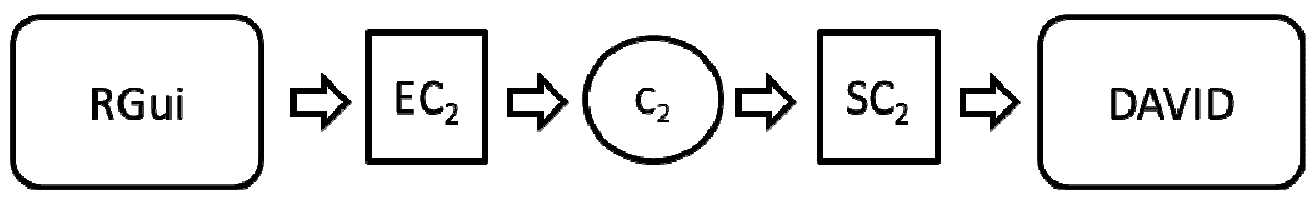

Figura 57: Integração das ferramentas RGui e DAVID através do conector $C_{2}$

Funcionalidade responsável por gerar os dados de entrada do conector $\left(\mathbf{R}_{5}\right)$ : Exportar dados em arquivo.

$\mathbf{E C}_{2}$ : Os dados de entrada do conector consistem nos dados gerados pela ferramenta RGui como resultado da funcionalidade $\mathrm{R}_{5}$. Esses dados devem estar contidos em um arquivo texto com formato delimitado por tabulações e devem consistir do resultado de um teste de hipóteses (teste t). A representação dos dados consiste de uma matriz na qual cada linha deve representar um gene e duas colunas de dados numéricos para informar o valor do teste $\mathrm{t}$ e $p$ value associado a cada gene. A Tabela 25 apresenta a descrição desses dados.

Tabela 25: Descrição dos dados relacionados à saída da funcionalidade $\mathbf{R}_{5}$

\begin{tabular}{|c|c|c|}
\hline Item de dado & Descrição semântica & Sintaxe de representação \\
\hline $\begin{array}{r}\text { Identificador de } \\
\text { um gene }\end{array}$ & $\begin{array}{l}\text { Dado que representa unn identificador de um } \\
\text { gene }\end{array}$ & $\begin{array}{l}\text { Conjunito de valures do lipo String apresenlados } \\
\text { na primeira coluna da matriz de dados em um } \\
\text { arquivo texto delimitado por tabulações }\end{array}$ \\
\hline $\begin{array}{r}\text { Valor resultado do } \\
\text { teste T }\end{array}$ & $\begin{array}{l}\text { Dado que representa um valor gerado pela } \\
\text { aplicação de um teste } t \text { associado a um gene e } \\
\text { mede a diferença normalizada pela variảncia } \\
\text { entre as médias das cuas amostras }\end{array}$ & $\begin{array}{l}\text { Conjunto de valores do tipo ponto flutuante } \\
\text { contidos na segunda coluna da matriz de dados em } \\
\text { um arquivo texto delimitado por tabulaçòes }\end{array}$ \\
\hline P-valor & $\begin{array}{l}\text { Dado que representa um valor gerado pela } \\
\text { aplicação de um teste t que exprime a } \\
\text { significância estatística desse resultado }\end{array}$ & $\begin{array}{l}\text { Conjuntos de valores do tipo ponto flutuante } \\
\text { contidos na terceira coluna da matriz de dados em } \\
\text { um arquivo texto delimitado por tabulaçoes }\end{array}$ \\
\hline
\end{tabular}

Funcionalidade responsável por consumir os dados de saída do conector (DAVID 1 ): Importar uma lista que contém identificadores de genes.

$\mathbf{S C}_{2}$ : Os dados de saída do conector consistem nos dados consumidos pela ferramenta DAVID através da funcionalidade DAVID 1 . Esses dados devem estar contidos em um arquivo texto com formato delimitado por tabulações e devem consistir de uma lista de identificadores dos genes. Dessa forma, cada linha do arquivo deve representar um gene 
selecionado que possui o valor resultado do teste t dentro de um critério de seleção. A Tabela 26 apresenta a descrição desses dados.

Tabela 26: Descrição dos dados de entrada relacionados à funcionalidade $\mathbf{R}_{1}$

\begin{tabular}{|r|l|l|}
\hline \multicolumn{1}{|c|}{ Item de dado } & \multicolumn{1}{|c|}{ Descrição semântica } & \multicolumn{1}{c|}{ Sintaxe de representação } \\
\hline $\begin{array}{r}\text { Identificador de } \\
\text { um gene }\end{array}$ & $\begin{array}{l}\text { Dado que representa um identificador de um } \\
\text { gene }\end{array}$ & $\begin{array}{l}\text { Conjunto de valores do tipo String apresentados } \\
\text { eml umlu listld coulidos enl uml arquivo lexlo } \\
\text { delimitado por tabulações }\end{array}$ \\
\hline
\end{tabular}

\section{F5. Modelagem conceitual dos dados de interesse.}

A Figura 58 ilustra a modelagem conceitual dos dados de interesse associados à entrada do conector $\left(\mathrm{EC}_{2}\right)$. A partir da descrição detalhada dos dados de interesse é possível identificar conceitos importantes: gene, valor resultado do teste t e $p$-value. Para cada linha do arquivo de entrada existe um identificador de gene que aparece uma única vez no mesmo arquivo, um valor resultado da aplicação de um teste de hipóteses (teste t) e p-value.

Dessa forma os seguintes conceitos foram identificados: Gene, que representa um gene cujo valor de expressão gênica foi mensurado, $P \_v a l u e$ e Valor_Teste_T, que representam valores resultantes da aplicação de um teste de hipótese dos dados e podem estar associados a um Gene. Um Valor_Teste_T está sempre associado a um P_value correspondente, o qual descreve a significância estatística do teste de hipótese. Contudo, nem sempre será possível realizar o teste de hipótese nos dados. Assim, o Valor_Teste_T associado a um gene possui cardinalidade 0 ou 1 . Isso significa que pode haver um $p$-value ou valor de teste $\mathrm{t}$ associado a um gene ou não, pois existem situações em que um valor de expressão gênica não está definido para um gene o que inviabiliza realizar um teste de hipóteses sobre esses dados.

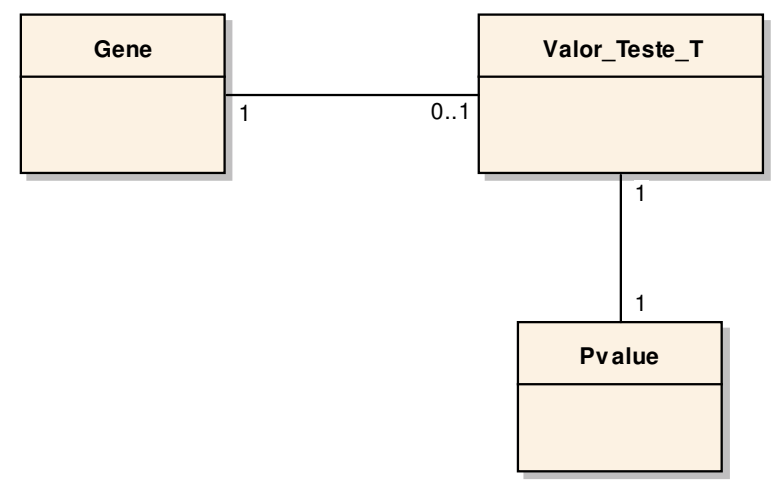

Figura 58: Modelagem conceitual associada à entrada do conector $C_{2}$ 
A Figura 59 ilustra a modelagem conceitual dos dados de interesse associados à saída do conector $\left(\mathrm{SC}_{2}\right)$. A partir da descrição detalhada dos dados de interesse é possível identificar um único conceito: gene. Para cada linha do arquivo de entrada existe um identificador de gene que aparece uma única vez.

Dessa forma apenas o seguinte conceito foi identificado: Gene, que representa um gene cujo valor de expressão gênica foi mensurado e possui significância estatística relevante para ser utilizado no agrupamento de genes com atribuições funcionais semelhantes.

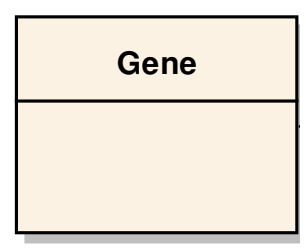

Figura 59: Modelagem conceitual associada à saída do conector $\mathrm{C}_{2}$

\section{F6. Mapeamento para ontologia de referência.}

A Tabela 27 apresenta o mapeamento entre os conceitos de cada modelo conceitual a conceitos da ontologia de referência.

Tabela 27: Mapeamento dos conceitos associados à entrada e à saída do conector $\mathrm{C}_{2}$ (terceiro estudo de caso) aos conceitos da ontologia de referência

\begin{tabular}{|c|c|c|}
\hline $\begin{array}{c}\text { Conceito entrada } \\
\text { conector }\end{array}$ & $\begin{array}{c}\text { Conceito ontologia } \\
\text { referência }\end{array}$ & $\begin{array}{c}\text { Conceito saída } \\
\text { conector }\end{array}$ \\
\hline Gene & Gene & Gene \\
\hline Valor_Teste_T & & \\
\hline P_value & & \\
\hline
\end{tabular}

Nesse mapeamento o conceito de entrada Gene foi corretamente associado à ontologia de referência e a um conceito de saída. Contudo, os conceitos Valor_Teste_T e $P_{-}$value não possuem nenhum conceito associado de saída e nenhum conceito da ontologia de referência. Contudo essa situação não é problema visto que Valor_Teste_T e $P$ _value são utilizados apenas como critérios para selecionar os identificadores de genes que possuem um valor estatisticamente significante de expressão a partir da análise do resultado do teste t. Dessa 
forma não é necessária a adição desses conceitos, por serem conceitos específicos para essa situação. Assim como valor de teste $\mathrm{t}$ e $p$-value existem outros valores que podem ser utilizados como critério de seleção, como por exemplo, resultados de outros testes estatísticos.

A Tabela 24 apresenta a adequação do mapeamento dos conceitos associados à entrada e saída do conector a conceitos da ontologia. Para essa situação foram necessárias adequações para possibilitar um mapeamento completo dos conceitos. Os conceitos Valor_Teste_T e P_value representam critérios de seleção associados a Gene, sendo, portanto, conceitos indiretos utilizados para gerar o conceito de saída Gene. Esse conceito de saída representa apenas os genes selecionados.

Tabela 28: Mapeamento dos conceitos associados a entrada e saída do conector a conceitos da ontologia de referência revisada

\begin{tabular}{|c|c|c|}
\hline $\begin{array}{c}\text { Conceito entrada } \\
\text { conector }\end{array}$ & $\begin{array}{c}\text { Conceito ontologia } \\
\text { referência }\end{array}$ & $\begin{array}{c}\text { Conceito saída } \\
\text { conector }\end{array}$ \\
\hline $\begin{array}{c}\text { Gene (Valor_Teste_T, } \\
\text { P_valor) }\end{array}$ & Gene & Gene \\
\hline
\end{tabular}

\section{F7. Adequação dos dados de interesse.}

Para esse cenário de integração serão necessárias adequações sintáticas e semânticas dos dados de interesse. Os dados de entrada inicial estão contidos em um arquivo texto separados por tabulações. A adequação sintática dos dados consiste na conversão dos dados extraídos desse arquivo em dados numéricos e textuais.

A adequação semântica dos dados consiste na transformação dos dados numéricos e textuais em representações dos conceitos identificados na modelagem conceitual. Dessa forma os valores de dados numéricos devem ser associados a resultado do teste t e $p$-value, enquanto que os valores textuais devem ser associados a informações sobre genes. Além disso, deve ser realizada uma filtragem dos dados, para gerar apenas uma apenas uma lista de identificadores de genes que possuem resultado do teste t e p-value dentro de um critério de seleção informado pelo usuário durante a execução do conector. 


\section{F8. Identificação de políticas de acesso e ativação.}

A ferramenta DAVID disponibiliza acesso remoto às suas funcionalidades e não restringe o acesso a esta ferramenta. Além disso, essa ferramenta não possibilita a transferência de controle automática a partir da execução do conector. A ativação pode ser realizada manualmente, utilizando um navegador para acessar as funcionalidades dessa ferramenta.

\section{F9. Implementação do conector.}

A Figura 60 ilustra o diagrama de classes UML do conector $\mathrm{C}_{2}$. Todas as classes foram implementadas utilizando a linguagem de programação Java.

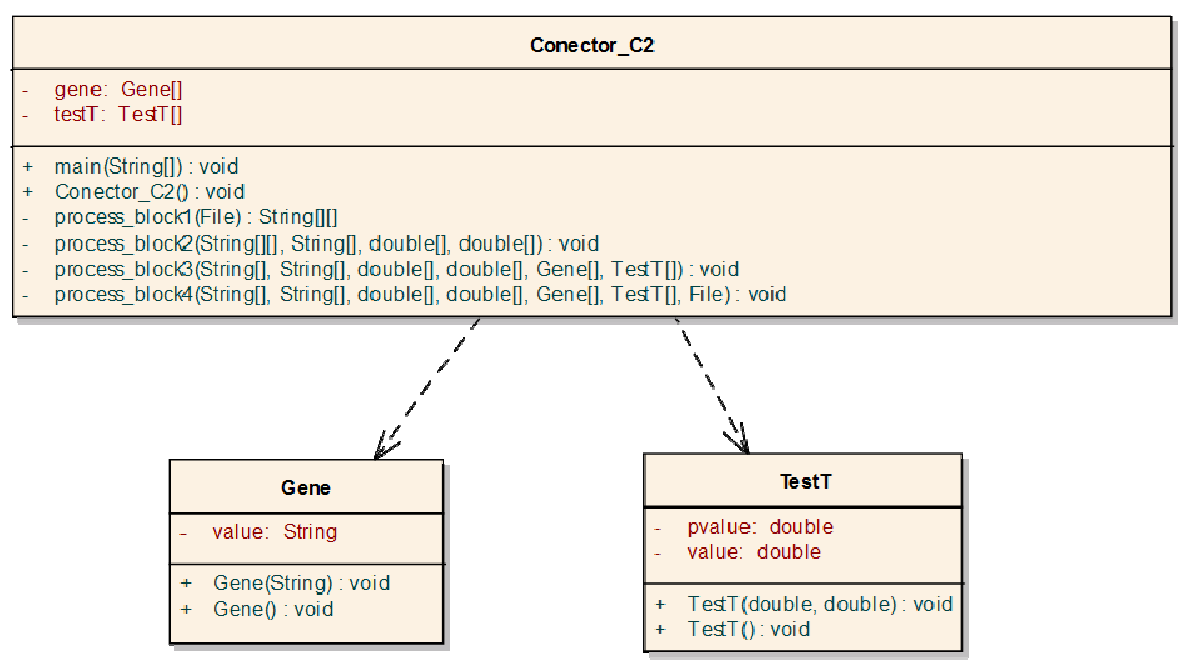

Figura 60: Diagrama das classes implementadas e utilizadas pelo conector $C_{2}$ (segundo estudo de caso)

As classes Gene e Test T foram criadas a partir dos conceitos identificados nos modelos conceituais. Gene é uma classe para representação de genes e, neste caso, armazena o identificador do gene. Test $T$ é uma classe para representação do resultado obtido da aplicação de um teste de hipóteses (teste T) nos dados de expressão gênica associados aos genes identificados. Essa classe armazena o valor resultado do teste t e o p-value. Esses valores foram modelados em uma única classe, pois para cada valor de teste t há um $p$-value associado.

Os blocos funcionais da classe Conector_C2, implementados como métodos da mesma, são executados sequencialmente, de modo que um bloco é executado somente após o término do bloco anterior. Os atributos dessa classe consistem de um vetor de genes (Gene) e um vetor de valores gerados a partir da aplicação de um teste de hipótese (Test T). O método main recebe como parâmetros o identificador do diretório que contém os arquivos com os 
dados de entrada, o identificador do diretório onde serão armazenados os dados de saída desse conector, o identificador do arquivo utilizado na ativação automática da ferramenta, se houver e pode conter os valores ( $p$-value e valor de teste $\mathrm{t}$ ) a serem utilizados como parâmetros da filtragem. O método process_blockl realiza o processamento inicial dos dados. Esse método recebe como parâmetro um identificador de arquivo (File) representando o diretório que contém os arquivos de entrada e retorna uma matriz de String a ser preenchida nesse método com os dados contidos nesses arquivos.

O método process_block2 realiza a adequação sintática através da transformação dos dados extraídos dos arquivos de entrada (matrizes de String) em dados numéricos e textuais de acordo com a informação que representam. Os parâmetros desse método consistem de uma matriz de String que contém os dados que foram extraídos do arquivo de entrada, um vetor de String que armazena os valores do cabeçalho contidos na primeira coluna e dois vetores de double, que armazenam os valores contidos na segunda e na terceira coluna da matriz.

O método process_block3 realiza a transformação semântica dos dados através da transformação das estruturas de dados definidas e instanciadas em process_block2 em instâncias das classes criadas a partir da modelagem conceitual (associação semântica). Esse método recebe como parâmetros um vetor de String, que contém os dados que foram extraídos da primeira coluna da matriz de dados, dois vetores de double, que armazenam os valores contidos na segunda e terceira colunas da matriz. Além disso, recebe como parâmetros dados a serem preenchidos nesse método, um vetor de genes (Gene), um vetor de dados gerados como resultado da aplicação de um teste de hipótese (TestT) que correspondem a valor teste te $p$-value.

O método process_block4 realiza o processamento dos dados de saída do conector e a ativação automática da ferramenta DAVID, se possível. Esse método recebe como parâmetros um vetor de genes (Gene), um vetor de dados gerados como resultado da aplicação de um teste de hipótese (TestT), um identificador de arquivo (File) representando o diretório onde esse arquivo será criado e dois valores double para representar o valor do teste t e p-value utilizados como parâmetros para filtragem dos dados. Esses valores são processados para gerar os dados de saída do conector. A ativação automática neste caso não é possível, pois a ferramenta DAVID não permite a transferência de controle (passagem da thread de execução) para a mesma de forma automática. 